\title{
Periodic Changes in the Nitrate Concentration of Stream and Inseepage Water in a Low-Relief Coastal Stream
}

\author{
Kristina Reid Black \\ Charlottesville, VA, USA
}

Bachelor of Science, Western Carolina University, 2003

A Thesis Presented to the Graduate Faculty of the University of Virginia in Candidacy for the Degree of Master of Science

Department of Environmental Sciences

University of Virginia

May 2014 


\section{Abstract}

Previous studies have shown relationships between evapotranspiration in riparian vegetation and diurnal changes in stage/discharge in adjacent streams. Such diurnal changes have been linked to diurnal changes in $\mathrm{NO}_{3}{ }^{-}$concentration in Cobb Mill Creek through alteration of retention time in biologically active stream sediment. Using stream stage records to confirm the diurnal effects of evapotranspiration on Cobb Mill Creek, the present study asked 1 ) if there is a periodic (i.e., diurnal) variation in water column $\mathrm{NO}_{3}{ }^{-}$ concentration similar to that observed for the stream stage? 2) do spatially distributed measurements of inseepage also show such a diurnal pattern? 3) does the concentration of $\mathrm{NO}_{3}{ }^{-}$in the inseepage vary diurnally? To address these questions, seepage meters were distributed along a reach of Cobb Mill Creek. A 10-day study in June 2010 confirmed a diurnal signal in both the stream stage and the $\mathrm{NO}_{3}{ }^{-}$concentration of the water column. However, the discharge and $\mathrm{NO}_{3}{ }^{-}$concentration of the inseepage from the meters lacked a similar diurnal signal. A second 3-day field campaign (September, 2010) employed similar methods to the first, but with a 2-hr sampling interval. The diurnal signal in stage was damped in September compared to June due to reduced precipitation during the summer which was presumed to have reduced plant activity and led to a significantly lower stream stage. Again, no diurnal signal was observed in the streambed discharge, inseepage $\mathrm{NO}_{3}{ }^{-}$ concentrations or the stream water column $\mathrm{NO}_{3}{ }^{-}$concentrations.

The results of this study confirmed the connection between stream stage, $\mathrm{NO}_{3}{ }^{-}$water column concentration and evapotranspiration. Unfortunately, it did not clarify if there is a connection between evapotranspiration and $\mathrm{NO}_{3}{ }^{-}$concentration of inseepage water even though theory predicts strongly that one should exist. Additional work will be necessary to demonstrate that relationship. 


\section{Table of Contents}

\section{Contents}

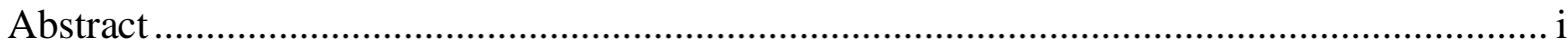

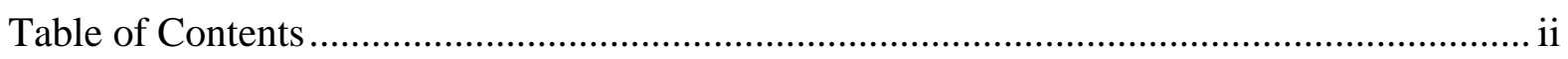

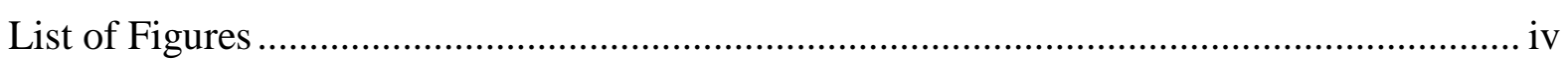

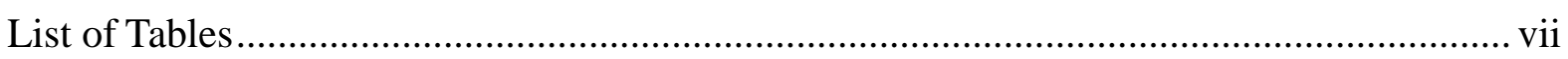

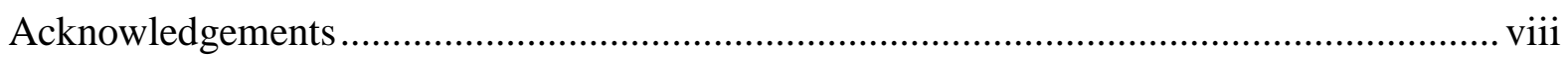

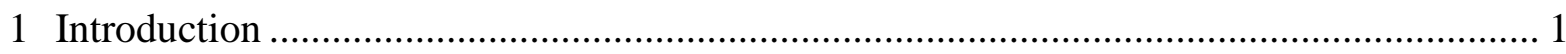

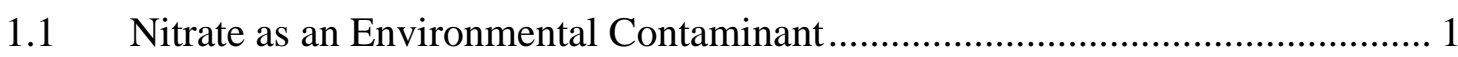

1.2 Environmental Consequences of $\mathrm{NO}_{3}{ }^{-}$-Contaminated Water ............................. 2

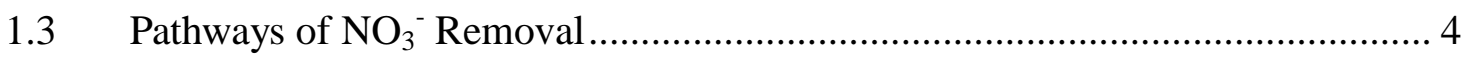

$1.4 \quad \mathrm{NO}_{3}{ }^{-}$Occurrence in Cobb Mill Creek ………............................................... 9

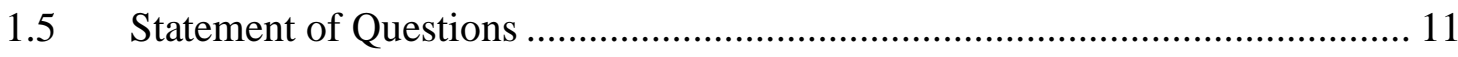

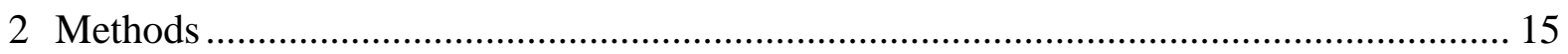

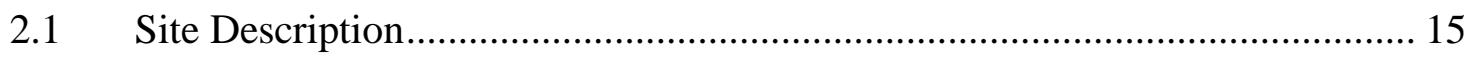

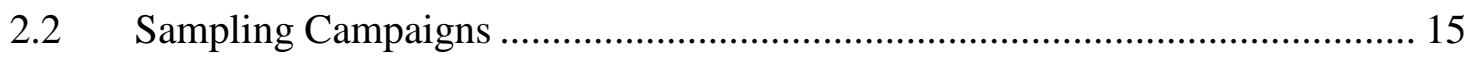

2.3 Sample Collection and Processing ............................................................... 17

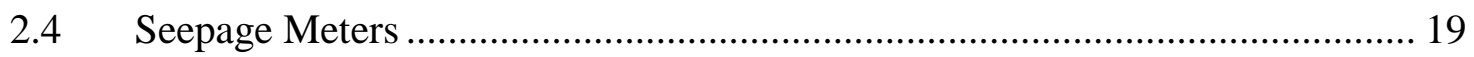

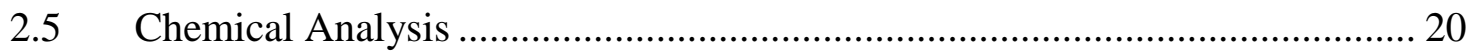

$2.6 \quad$ Sediment pore water samples............................................................... 22

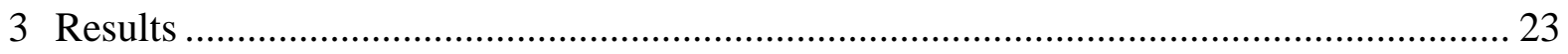

3.1 Diurnal variation in stream stage and $\mathrm{NO}_{3}{ }^{-}$concentrations ........................... 23

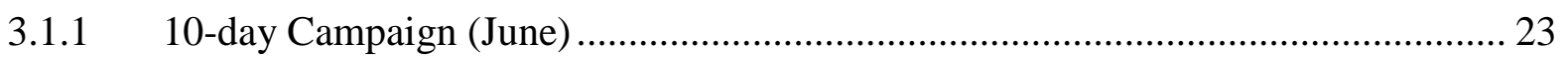

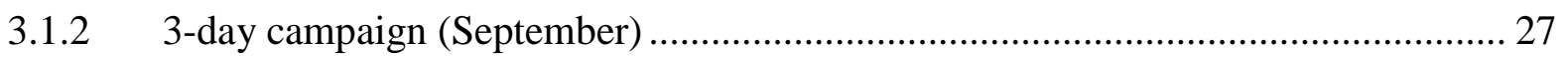

3.2 Measurement of inseepage from Cobb Mill Creek sediment .......................... 28

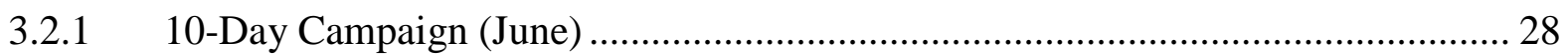

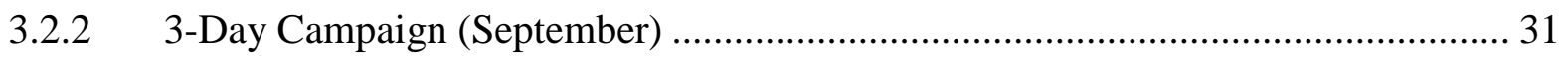

3.3 Nitrate concentration in collected inseepage ……........................................ 32

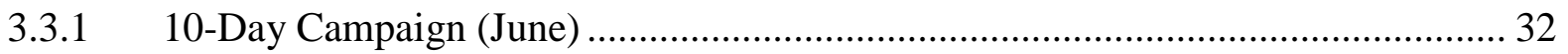

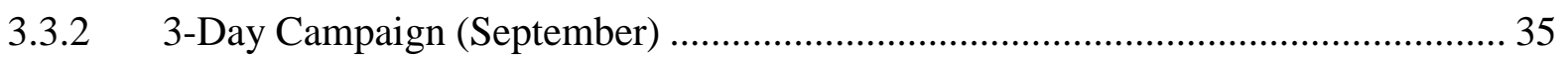

3.4 Pore Water Samples from the 3-Day (September) Campaign .......................... 36

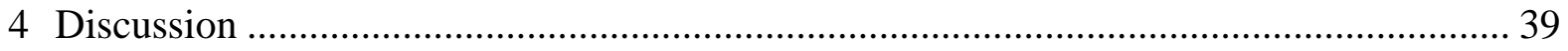

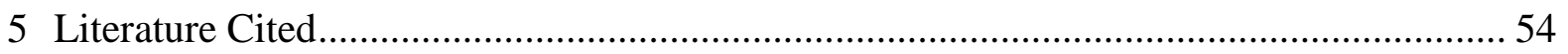

Appendix A. Inseepage results for individual seepage meters for June, 2010 ...................... 59 
Appendix B. Inseepage results for individual seepage meters, September, 2010

Appendix C. Concentration of $\mathrm{NO}_{3}{ }^{-}$in inseepage collected from individual meters in June, 2010 . 82

Appendix D. Nitrate concentration in individual seepage meters, September, 2010 98

Appendix E. C-Q $\left(\mathrm{NO}_{3}{ }^{-}\right.$concentration vs. discharge) plots for individual seepage meters over time in June 2010

Appendix F. CQ (concentration vs.discharge) plots for individual seepage meters in

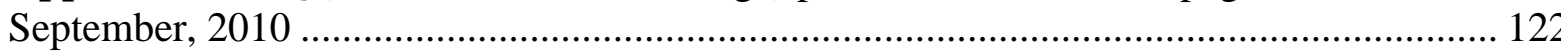

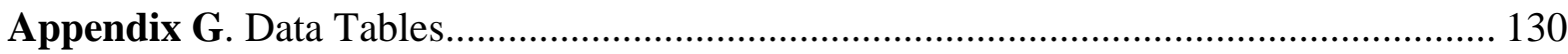




\section{List of Figures}

Figure 1. A generalized representation of the nitrogen cycle including processes described in this report. Redrawn from (Blum and Mills, 2012)

Figure 2. Spectral analysis of daily stage fluctuations at Cobb Mill Creek (Figure from Robertson, 2009). The period is the number of sample events at which autocorrelation is observed, and the "periodogram" represents the strength of the autocorrelation. Because samples were collected at 10-min intervals, the occurrence of the peaks at 144 indicates a strong signal that recurs exactly at 24-hr intervals (144 samples per day). The small winter signal (actually in March) is likely due to a few evergreen trees and some non-deciduous shrubs near the stream. Detrending of the data was done by the first difference method.

Figure 3. Map of chloride concentrations (A) and nitrate concentrations (B) in $\mathrm{mg} \mathrm{L}^{-1}$ in groundwater discharge from the streambed on 8/02/2007(Flewelling, 2009).

Figure 4. Site map of Cobb Mill Creek on Virginia's Eastern Shore. Elevation units are meters above mean sea level.

Figure 5. Location and arrangement of seepage meters at the hillslope at Cobb Mill Creek in June and September (not to scale). Also shown are the location of the stilling well for obtaining stage measurements and the intake of the ISCO sampler where stream water samples were collected hourly.

Figure 6. A deployed seepage meter. The can is $10 \mathrm{~cm}$ in diameter and $7 \mathrm{~cm}$ long. The can is pressed into the sediment such that no more than $1 \mathrm{~cm}$ extends above the sediment surface.

Figure 7. Relative stage (in cm, not corrected to sea level) at the hillslope of Cobb Mill Creek during the 10-day experimental period in June, 2010. The storm hydrograph for the rain occurring in the early morning of June 15 (the day before the onset of the actual observations).

Figure 8. Variation in stream stage over the 10-day observation period after detrending (in this case by subtracting a quadratic function fitted to the data from each measured value in the dataset).

Figure 9. Spectral analysis of the stage data for the 10-day campaign in June. A strong (but broad) peak is apparent that is centered on 144 samples representing autocorrelation with a 24-hr lag.

Figure 10. Concentration of $\mathrm{NO}_{3}{ }^{-} \mathrm{N}$ in stream water samples taken hourly in Cobb Mill Creek. The upper panel represents the uncorrected raw data. The lower panel represents the same data after filtering the very low values thought to arise from sample contamination. Malfunction of the automatic sampler prevented sample collection from 12:00 on 6/21 to $11: 00$ on $6 / 22$. 
Figure 11. Spectral analysis of streamwater $\mathrm{NO}_{3}{ }^{-}$concentrations for the period from $6 / 21$ to $6 / 25$, when the effect of the storm just before the sampling period was no longer felt. Detrending was not applied to these data

Figure 12. Stage in Cobb Mill Creek during the 3-day campaign in September. Data were excised from a longer record collected by our research group and maintained as part of the VCR-LTER database. Note that in this case, the record begins at noon on 9/23 and continues to $11: 50$ on $9 / 26$. Spectral analysis of the data yielded a strong peak at a $24-\mathrm{h}$ lag time with a smaller secondary peak at $12 \mathrm{hr}$.

Figure $13 . \mathrm{NO}_{3}{ }^{-}$concentration in stream water collected hourly during the September 2010, 3-day campaign. Data are unfiltered, unlike those presented for the 10-day campaign Figure 10). Note the occurrence of a few anomalously low values in the record, similar to those seen in the June data.

Figure 14. Groundwater discharge into the seepage meters placed in Cobb Mill Creek in June, 2010. The arrangement of the plots depicts the general arrangement of the meters throughout the stream reach (see Figure 5). Note that the individual graphs and data are contained in Appendix A1-A15. The axes of the plots are all identical and are depicted at the lower left of the figure

Figure 15. Discharge (volume collected / collection period [i.e., $6 \mathrm{hr}$ ]) in seepage meter 1 (SM1) during the 10-day campaign. No periodic pattern in discharge was seen during the time of observation. The green line is not a fit to the data, but it is included to show what a periodic pattern might appear if the maxima and minima were at 06:00 and 18:00, respectively. The range of values ( 0 to $\left.0.5 \mathrm{~mL} \mathrm{~min}^{-1}\right)$ was selected to capture the full range of values actually observed in the data. With samples collected every 6 hours, a curve with the resolution similar to that depicted by the green line could not be obtained.

Figure 16. Groundwater discharge into the seepage meters placed in Cobb Mill Creek for 3 days in September, 2010. The arrangement of the plots depicts the general arrangement of the meters throughout the stream reach (see Figure 5). Lines connecting the data points were added to simplify following the seepage values with time. Note that the individual graphs and data are contained in Appendix B1-B6.

Figure 17. Concentration of $\mathrm{NO}_{3}{ }^{-}$in samples of seepage taken from the various meters deployed in Cobb Mill Creek during the 10-day campaign in June of 2010.

Figure 18. Distribution of travel times computed from seepage-meter data collected in June and September.

Figure 19. Concentration of $\mathrm{NO}_{3}{ }^{-}$in samples of seepage taken from the various meters deployed in Cobb Mill Creek during the 3-day campaign in September of 2010.

Figure 20. Concentrations of $\mathrm{NO}_{3}{ }^{-}-\mathrm{N}$ in porewater samples extracted from Cobb Mill Creek sediments during the September campaign. Nitrate decreased with decreasing depth in the 
sediment suggesting removal of nitrate as the groundwater discharged toward the surface. The value at $1-\mathrm{cm}$ above the sediment surface represents samples of the stream water collected along with the groundwater samples. Values presented are the mean \pm 1 standard deviation of all 36 samples collected (12/day $\times 3$ days $)$.

Figure 21. Fit of a sine function to stream stage (black) and streamwater $\mathrm{NO}_{3}{ }^{-}$concentration in Cobb Mill Creek for a 24-hr period on June 24 to 25. One day of a longer set is plotted here to provide a detailed view of the timing of the daily maximum and minimum for each of the measured variables.

Figure 22. $\mathrm{NO}_{3}{ }^{-}$concentration plotted against discharge (C vs. Q) in seepage meters deployed in Cobb Mill Creek in June of 2010.

Figure 23. $\mathrm{NO}_{3}{ }^{-}$concentration plotted against discharge (C vs. Q) in seepage meters deployed in Cobb Mill Creek in September of 2010. 


\section{List of Tables}

Table 1: Descriptive statistics for $\mathrm{NO}_{3}{ }^{-}$concentrations in samples from the 6 seepage meters deployed in September. Similar superscript letters associated with the meter identifier indicate no significance difference between that meter and any other with the same letter appended (one-way ANOVA with pairwise comparison using Tukey's test). Median values suggest the data are skewed.

Table 2: Literature reports of the timing of diurnal maximum values for several variables associated with groundwater stream water interactions. 


\section{Acknowledgements}

I would like to express my deepest appreciation to Dr. Aaron Mills for his countless hours working on my thesis and his tireless guidance. His willingness to work around my full-time work schedule for the last couple years has made this thesis a reality. I will always have fond memories of our numerous trips to the Eastern Shore and the requisite pit stops for Pierce's BBQ. I would like to also thank my committee members, Dr. Janet Herman and Dr. Peter Berg for their guidance and invaluable knowledge. In addition, I would like to thank Dr. Herman for generously allowing me to borrow equipment for long periods of time, invasion into her lab space and assisting with the 24-hr sampling events. I greatly appreciate Dr. Berg's technical assistance and the generous use of his sampling equipment. Their contributions are sincerely appreciated and gratefully acknowledged.

I would also like to thank the many friends and colleagues who provided guidance, support, and countless hours of their time to assist with the samplings. Thank you Meg Miller, Joe Battistelli, Olivia Reid, and Matthew Black. I want to give special thanks to my husband, Matthew Black, who moved to Charlottesville for my pursuit of a graduate degree and who has patiently supported me over the years.

Without the support of the LTER network and the National Science Foundation grants BSR-8702333-06, DEB-9211772, DEB-9411974, DEB-0080381, DEB-0621014 and DEB1237733, this research would not have been possible. The Anheuser-Busch Coastal Research Center was an excellent home base for processing the numerous samples. The project site manager, Art Schwarzschild, was exceedingly accommodating with the many volunteers working on this project and provided much needed housing and gear for this research. 


\section{Introduction}

\subsection{Nitrate as an Environmental Contaminant}

Because of its widespread use as an agricultural and residential fertilizer, nitrogen, particularly as $\mathrm{NO}_{3}{ }^{-}$, has become ubiquitously distributed in ground and surface waters (1997). Numerous ecological and health-related issues have been directly linked to $\mathrm{NO}_{3}{ }^{-}$in water, and the US EPA has set a regulatory maximum of $10 \mathrm{mg} \mathrm{NO}_{3}^{-}-\mathrm{N} \mathrm{L}^{-1}$ for all drinking water (Boesch et al., 2001; Rabalais et al., 2001). The concentration of $\mathrm{NO}_{3}{ }^{-}-\mathrm{N}$ exceeds that limit in the groundwater of a majority of agricultural regions (Denver et al., 2003). The most important effects of the excess nitrogen deal with the degradation of important water systems by eutrophication. The USDA and USEPA in 1998 reported estimates of $\mathrm{NO}_{3}{ }^{-}$contamination in $40 \%$ of rivers and $57 \%$ of estuarine waters in the US. Application of nitrogenous fertilizer is one of the top three sources of pervasive $\mathrm{NO}_{3}{ }^{-}$contamination of the environment (Korom, 1992; Spalding and Exner, 1993), with the other two being nitrogen fixation by lightning strikes and the burning of fossil fuels. Agricultural fertilization has increased exponentially since the creation of the Haber-Bosch process in 1931 and its subsequent role in global sustainability due to its use as a fertilizer source (Winter et al., 1998). The Haber-Bosch process was initially developed to produce ammonia from atmospheric nitrogen. The ammonia could then be used to generate $\mathrm{NO}_{3}{ }^{-}$for munitions production during World War II. After the war, the Haber-Bosch product was subsequently used as a nitrogen source for fertilizer, and the industrially fixed $\mathrm{N}$ was applied to soil and it largely replaced the use of animal waste as an inexpensive fertilizer to agricultural fields around the globe. As an unforeseen consequence of an increased ability to produce food, the global population climbed from about 1.6 billion people in 1900 to about 7 billion people today (Ritter $\mathrm{et} \mathrm{al.,}$ 2008). 
Concomitant with the increase in the world's population was a rise in industrial farming despite a significant drop in the total number of farms working the land. Two of the primary sources of $\mathrm{NO}_{3}{ }^{-}$contamination in the environment, fertilizers and the burning of fossil fuels, have seen an increase on the average industrial farm. Despite a drop in fertilizer use in other industrial nations, the US has seen a slow steady increase since the 1980s (International Energy Agency, 2008). The developing world has a significant dependence on synthetic fertilizers and the upward trend in its use does not show signs of slowing down. China uses 2.5 times the fertilizer used by the US in a year but the US uses 4 times as much fertilizer N on a per capita basis. (Heinberg and Bomford, 2009).

\subsection{Environmental Consequences of $\mathrm{NO}_{3}{ }^{-}$-Contaminated Water}

Many coastal areas including the Chesapeake Bay and other Virginia coastal communities are now contending with the eutrophication created by the input of anthropogenic $\mathrm{NO}_{3}{ }^{-}$. Eutrophication is the process by which excess nitrogen and phosphorus enters coastal waterways and promotes extensive production of algae and plants. Eutrophic waters are characterized by increased turbidity, an abundance of toxic or inedible phytoplankton, changes in macrophyte species, etc. The elevated algal growth coupled with bacterial decay of the cells eventually creates an oxygen deficiency in the water (aquatic hypoxia), also known as a "dead zone". Concomitantly, that leads to the death of aquatic species that require oxygen to survive, including many fish and shellfish of aesthetic or economic importance. In addition to their detrimental effects to the coastal environment, the blooms of algae and bacteria can reduce the surrounding air quality through the release of spores and noxious gases created as a byproduct of the bacterial breakdown of the algal bloom. The "dead zone" phenomenon has become increasingly frequent in the coastal waters surrounding Florida and the Gulf of Mexico (Rabalais et al., 2001), and the affected area 
created by eutrophication increases each year. A 2010 World Resources Institute eutrophication map identifies 131 eutrophic and hypoxic coastal zones in North America and the Caribbean; the Chesapeake Bay alone had 12 distinct zones, which were identified by water quality data (www.wri.org/eutrophication/map). Only 10 of the 131 identified zones were listed as recovering from eutrophication. According to the Virginia Oyster Growers directory (http://virginiaoysters.org/vao-growers/), there are over 40 shellfish farms along the Eastern Shore of Virginia, which rely on the local waters as a source of income. Increased eutrophication of local waters could lead to a loss of suitable fish and shellfish habitat. A study by Dodds et al. (2009) found that there was approximately a $\$ 2.2$ billion cost associated with the economic repercussions of US freshwater eutrophication, and that was considered to be most likely an underestimate of the true cost.

Aside from the ill effects of $\mathrm{NO}_{3}{ }^{-}$-contaminated water on environmental and economic health, there is a direct effect on human health from $\mathrm{NO}_{3}{ }^{-}$-contaminated water is a syndrome known as "Blue Baby" (Knobeloch et al., 2000). When babies ingest $\mathrm{NO}_{3}{ }^{-}$-contaminated water or food they are at risk to develop infant methemoglobinemia. In this illness, microbes in the digestive system reduce $\mathrm{NO}_{3}{ }^{-}$to $\mathrm{NO}_{2}{ }^{-}$which then enters the bloodstream and combines with hemoglobin blocking $\mathrm{O}_{2}$ transport much in the same way as carbon monoxide. The reduced $\mathrm{O}_{2}$-carrying capacity of the blood has a visible effect of turning the skin surrounding the lips, hands and feet to a bluish-gray or lavender color (a condition called cyanosis). As the syndrome progresses the infant may become more irritable and lethargic as the concentration of methemoglobin increases concomitantly decreasing the ability of the blood to transport oxygen. When methemoglobin levels exceed 50\%, the infant will go into a coma and eventually die if not treated for the $\mathrm{NO}_{2}^{-}$poisoning immediately. In rural areas lacking 
access to a municipal water supply, groundwater wells are the primary water source. Well water can become easily contaminated with $\mathrm{NO}_{3}{ }^{-}$, especially if the land surrounding the well is intensively farmed and fertilized. The same study (Knobeloch et al., 2000) also reviewed several other papers that report a possible linkage between $\mathrm{NO}_{3}{ }^{-}$-contaminated food and water and an assortment of illnesses, including an increased risk for gastric cancer, increased incidence of central nervous system and brain cancer, non-Hodgkin Lymphoma, and a connection to insulin-dependent diabetes mellitus. Though direct linkage of nitrate contaminated food and water has not been conclusively proven, it is apparent that further studies are needed to fully grasp the issues surrounding the prevalent $\mathrm{NO}_{3}{ }^{-}$pollution of US waters.

\subsection{Pathways of $\mathrm{NO}_{3}{ }^{-}$Removal}

The pathway of nitrogen importation to waterways is highly dependent on local geomorphic characteristics and land usage. Vegetative buffers bordering streams and rivers in the riparian zone, have been found to mitigate much of the deleterious effects of agricultural over-fertilization (Lowrance, 1998; Lowrance et al., 1997; Lowrance et al., 2000; Lowrance et al., 1984; Maag et al., 1997; Nelson et al., 1995; Norton and Fisher, 2000; Ocampo et al., 2006; Pavel et al., 1996; Pinay et al., 1993; Simmons et al., 1992; Warwick and Hill, 1988; Willems et al., 1997). Removal of $\mathrm{N}$ from the discharging groundwater is accomplished in two primary ways, through plant uptake and by denitrification processes (Figure 1) in the soil (Canter, 1997; Kennedy et al., 2009b; Rabalais et al., 2001). In some cases, however, nutrient-rich water from upland agricultural fields can pass under the biologically active portion of the riparian zone and enter the stream without benefit of the "treatment" afforded by the riparian filter. The movement of water to the stream by flowpaths that do not take it through the active riparian zone has been termed 


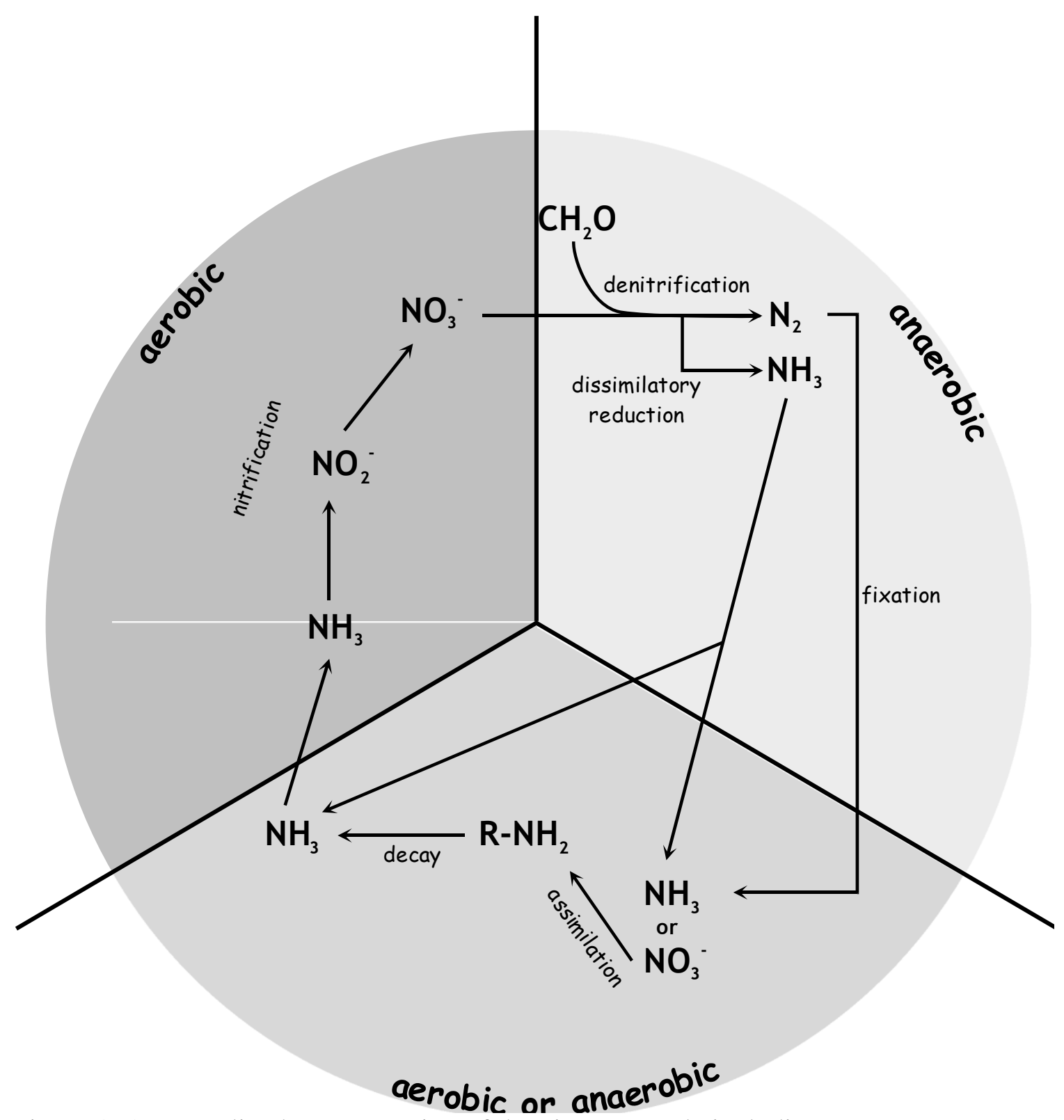

Figure 1 A generalized representation of the nitrogen cycle including processes described in this report. Redrawn from (Blum and Mills, 2012)

"bypass" (Gold et al., 2001; Ranalli and Macalady, 2010). In cases of riparian bypass, water usually travels below the biologically active zone proximal to the stream such that $\mathrm{NO}_{3}{ }^{-}$in the discharging groundwater is exposed to neither plant uptake nor denitrification. The water intersects the streamwater-sediment interface, and in many cases discharges to the stream delivering all the $\mathrm{NO}_{3}{ }^{-}$that was present in the groundwater such that the concentration of 
$\mathrm{NO}_{3}{ }^{-}$in the stream is the same or nearly the same as that in the groundwater (Denver et al., 2003; McCarty et al., 2008).

In other cases, however, organic matter in streambed sediments can provide the energy source for denitrification of the $\mathrm{NO}_{3}{ }^{-}$as the water passes through the last several centimeters of sedimentary material before discharging to the stream. In Cobb Mill Creek, a well-studied, low-relief coastal stream that drains agricultural fields on Virginia's Eastern Shore, denitrification in the top 30-40 cm of bed sediment removes $70 \%-90 \%$ of the $\mathrm{NO}_{3}{ }^{-}$from the water as it rises through the sediment to the stream channel (Flewelling et al., 2012; Gu, 2007; Gu et al., 2008a; Gu et al., 2008b; Gu et al., 2007; Mills et al., 2008). The organic matter in the sediments is thought to be derived from burial of the annual input of foliage from the trees adjacent to the stream that senesce in the autumn (Gu et al., 2007; Mills et al., 2008). Thus, vegetative buffers also contribute a significant and reoccurring portion of the organic matter which is a vital part of denitrification processes.

In a review by Ranalli and Macalady (2010), it was found that removal of $\mathrm{NO}_{3}{ }^{-}$is most efficient in small headwater streams and becomes nonexistent in larger rivers. In addition, several papers corroborate the fact that low flows provide better $\mathrm{NO}_{3}{ }^{-}$removal due to longer retention time in the riparian sediments (Hill, 1990; Valett et al., 1996). Gu et al. (2008a; Gu et al., 2008b; Gu et al., 2007) and Flewelling et al. (2012) demonstrated that in Cobb Mill Creek sediments, that longer retention times, leads to reduced breakthrough of $\mathrm{NO}_{3}{ }^{-}$into the stream water.

Denitrification occurs through a series of pathways that are microbially mediated. Facultative anaerobes remove $\mathrm{NO}_{3}{ }^{-}$from a system through denitrification (equation 1) whereby $\mathrm{NO}_{3}{ }^{-}$is reduced to $\mathrm{N}_{2}$ which is no longer reactive. 


$$
5 \mathrm{CH}_{2} \mathrm{O}+4 \mathrm{NO}_{3}{ }^{-}+4 \mathrm{H}^{+} \rightarrow 2 \mathrm{~N}_{2}+5 \mathrm{CO}_{2}+2 \mathrm{H}_{2} \mathrm{O}
$$

Additionally, in some situations inorganic nitrogen in the environment can be converted to $\mathrm{N}_{2}$ by anaerobic ammonium oxidation (anammox) (equation 2).

$$
\mathrm{NH}_{4}{ }^{+}+\mathrm{NO}_{2}^{-} \rightarrow \mathrm{N}_{2}+2 \mathrm{H}_{2} \mathrm{O}
$$

Both processes provide alternative pathways to the removal of $\mathrm{NO}_{3}{ }^{-}$from a location, but neither contributes to nitrogen removal at Cobb Mill Creek (Mills et al., 2008). The authors reported the lack of ammonia at Cobb Mill Creek, which ruled out dissimilatory nitrate reduction (DNRA) and anammox both of which require the presence of ammonia. In that report and the studies on which it was based, denitrification reactions accounted for all of the loss of $\mathrm{NO}_{3}{ }^{-}$from groundwater discharging into the stream channel (Galavotti, 2004; Mills et al., 2011; Mills et al., 2008).

The reduction of $\mathrm{NO}_{3}{ }^{-}$to $\mathrm{N}_{2}$ is an ideal answer to the problem of excess $\mathrm{N}$ because of the biologically inert character of $\mathrm{N}_{2}$ in ground and surface waters alike. Denitrification in Cobb Mill Creek takes place in the upper region of the sediment that is organically rich and anoxic (Mills et al., 2008). Ideally, the $\mathrm{NO}_{3}{ }^{-}$-enriched groundwater first encounters this biologically active portion of the sediment as the water discharges toward the stream, and the contact time or retention time within that active zone would be long enough to allow for the denitrification reaction to occur. The organic-matter maximum, and, hence, the biologically active zone, is located around $20-50 \mathrm{~cm}$ below the sediment surface in Cobb Mill Creek. The organic matter in the sediment is thought to be due to the burial of organic matter, created by leaf litter from surrounding riparian zones, into the streambed during storm events.

Despite the acknowledgement of the practical importance of this issue by numerous 
environmental organizations and government agencies recently, few mandates are in place to guide the establishment of riparian zones on the Eastern Shore of VA (Virginia Department of Forestry code 58.1-339.10, Chesapeake Bay Program). There are several factors that affect the denitrification process, namely the slope of the riparian zone, groundwater level, and hydrological pathway of the groundwater (Kennedy et al., 2009b). A complication that impedes the development of riparian buffer/nitrate mitigation guidelines is the fact that there are numerous features (soil composition, hill slope, watershed aspect, etc.) that can cause the $\mathrm{NO}_{3}{ }^{-}$-enriched ground water to bypass the biologically active and organically-rich portion of the riparian zone (Gold, et al. 2001). When groundwater bypass occurs, $\mathrm{NO}_{3}{ }^{-}$removal prior to discharge to the stream channel depends entirely on denitrification in the stream sediments (Mills, et al. 2008). Sprague et al. (2000) examined the stream import of nitrogen to the Chesapeake Bay from its watersheds and found that $15-65 \%$ of the nitrogen in streams in the entire watershed was transported by groundwater seepage. The highly permeable soils of the Eastern Shore effectively route water to subsurface flow with little overland flow, suggesting the amount of nitrogen thus transported probably exceeds the average values reported by Sprague et al. (2000).

In Cobb Mill Creek, there is little change in the nature of the nitrogen either quantitatively or qualitatively, once the percolating water containing the excess fertilizer is below the active root zone (Mills et al., 2008). Inorganic $\mathrm{N}$ travels largely as $\mathrm{NO}_{3}{ }^{-}$and is not subject to substantial alteration as the ground water passes through the aquifer to the stream. In the portion of the stream studied extensively by our research group, there is little interaction with plants or surface materials in the riparian zone (a phenomenon known as riparian bypass (Gold et al., 2001; McCarty et al., 2008)), such that the $\mathrm{NO}_{3}{ }^{-}$is delivered 
directly to the stream through the bed sediments (Flewelling et al., 2012; Gu et al., 2008b; Mills et al., 2008). Earlier studies carried out in the laboratory and field, combined with modeling efforts (Flewelling et al., 2012; Gu et al., 2007) have demonstrated that denitrification in the streambed sediments removes a substantial amount of the $\mathrm{NO}_{3}{ }^{-}$from the discharging water, and that the residence time of that $\mathrm{NO}_{3}{ }^{-}$-enriched water in the sediments controls the amount removed. Factors which alter that residence time, then, should also alter the flux of $\mathrm{NO}_{3}{ }^{-}$to the stream channel. For example, Gu et al. (2008a) demonstrated that a passing flood wave could either inhibit or enhance the flux of $\mathrm{NO}_{3}{ }^{-}$from the aquifer to the stream depending on the magnitude of the wave.

\section{$1.4 \mathrm{NO}_{3}{ }^{-}$Occurrence in Cobb Mill Creek}

The dependence of denitrification effectiveness on residence time in streambed sediments has been well demonstrated at Cobb Mill Creek (Flewelling et al., 2012; Gu et al., 2008b; Gu et al., 2007). A review of nitrate removal by Ranalli and Macalady (2010) found that denitrification can take place in small streams with low flow, due to the longer residence time. Retention time has an effect on $\mathrm{NO}_{3}{ }^{-}$concentrations and seasonal changes to groundwater discharge rates could lead to changes in the efficiency of the denitrification process. Flewelling et al. (2012) and Gribovszki et al. (2008) gave evidence that evapotranspiration can have a significant impact on the discharge of groundwater to adjacent streams and the concomitant effect on the residence time of the groundwater in the stream sediments, which may control the $\mathrm{NO}_{3}{ }^{-}$concentration in the stream water. However, the influence that evapotranspiration may have on this process is not entirely clear. Diurnal variation of the stream stage is pronounced during the growing season at Cobb Mill Creek, and in a short (3-day) study, $\mathrm{NO}_{3}{ }^{-}$concentration appeared to vary diurnally along with the stream stage (Robertson, 2009). The stream stage and $\mathrm{NO}_{3}{ }^{-}$concentrations in the stream 
water peaked around 11:00 and was at minimum at around 17:00, times which roughly correlated to the daily evapotranspiration cycle (increased evapotranspiration from approximately 8 am to 8 pm during summer months) created by the trees within the riparian zone. However, whether evapotranspiration plays affects the concentration of $\mathrm{NO}_{3}{ }^{-}$entering the stream from the groundwater is poorly understood at the Cobb Mill Creek site. Flewelling et al. (2013) used a model to support the supposition that ET, by its influence on the rate of discharge of groundwater to the stream from the sediments, could generate a diurnal fluctuation in streamwater $\mathrm{NO}_{3}{ }^{-}$concentrations, and the model results approximated Robertson's (2009) data. Although the short duration of the study did not provide a quantitatively clear signal in any of the parameters measured, spectral analysis of the stage data from Cobb Mill Creek during a summer (July) and a winter (February/ March) clearly demonstrates that stream stage fluctuations have a strong, monotonic signal with a period of twenty-four hours (Figure 2) during the summer when evapotranspiration is expected to be maximal and only a very small signal (also with a 24-hr frequency) in early spring before the trees open their leaves.

To appropriately address the questions about temporal variability, the spatial distribution of the discharge of water (i.e., seepage) and $\mathrm{NO}_{3}{ }^{-}$through the streambed must be considered. Kennedy et al. (2009a) pointed to the consistent relationship between groundwater age and $\mathrm{NO}_{3}{ }^{-}$concentration. In addition, Kennedy et al. (2009b) indicated that different agricultural practices on opposite sides of a stream could also influence the $\mathrm{NO}_{3}{ }^{-}$concentration of the groundwater flux to the stream. A spatial relationship between $\mathrm{NO}_{3}{ }^{-}$concentration and inseepage rates does exist for Cobb Mill Creek (Figure 3, (Flewelling et al., 2012)). In conjunction with the proposed study into the temporal questions of diurnal variation in the inseepage 
nitrate concentration, PET and inseepage rates, it would prudent to examine possible spatial variability within the Cobb Mill Creek stream reach at the same time. This would clarify if the different land usage and slopes on each side of the stream affect the diurnal signal and nitrate concentrations of the streamwater.

\subsection{Statement of Questions}

A review by Gribovszki et al. (2008) and subsequent modeling effort by Szilagyi et al. (2008) to further corroborate the involvement of evapotranspiration on stream and groundwater levels. Numerous studies have recorded a diurnal fluctuation when stage levels were recorded on an hourly basis. However, over the course of a year, after collecting 10minute water and stage samples Gribovszki et al. (2008) found clear evidence of a diurnal signal. The authors were the first to also report a definite offset in the diurnal signal of stream stage. Similar results were obtained by Robertson (2009) during the short period of her study at Cobb Mill Creek for streamwater nitrate concentration and not for the stream stage diurnal signal. Confirming and questioning the causation of the diurnal streamwater nitrate concentrations at Cobb Mill creek is necessary to understand the microbial involvement in denitrification of $\mathrm{NO}_{3}{ }^{-}$in groundwater. Robertson (2009) conducted a brief research campaign with sample collection occurring at a less than ideal frequency. A longer research campaign with increased sample collection frequency would produce enough data to discern if there is a diurnal signal in the stream stage. Which leads to the question, "is there a periodic (i.e. diurnal) variation found within the water column $\mathrm{NO}_{3}{ }^{-}$concentration and how is it related to the observed diurnal signal in the stream stage? “ 


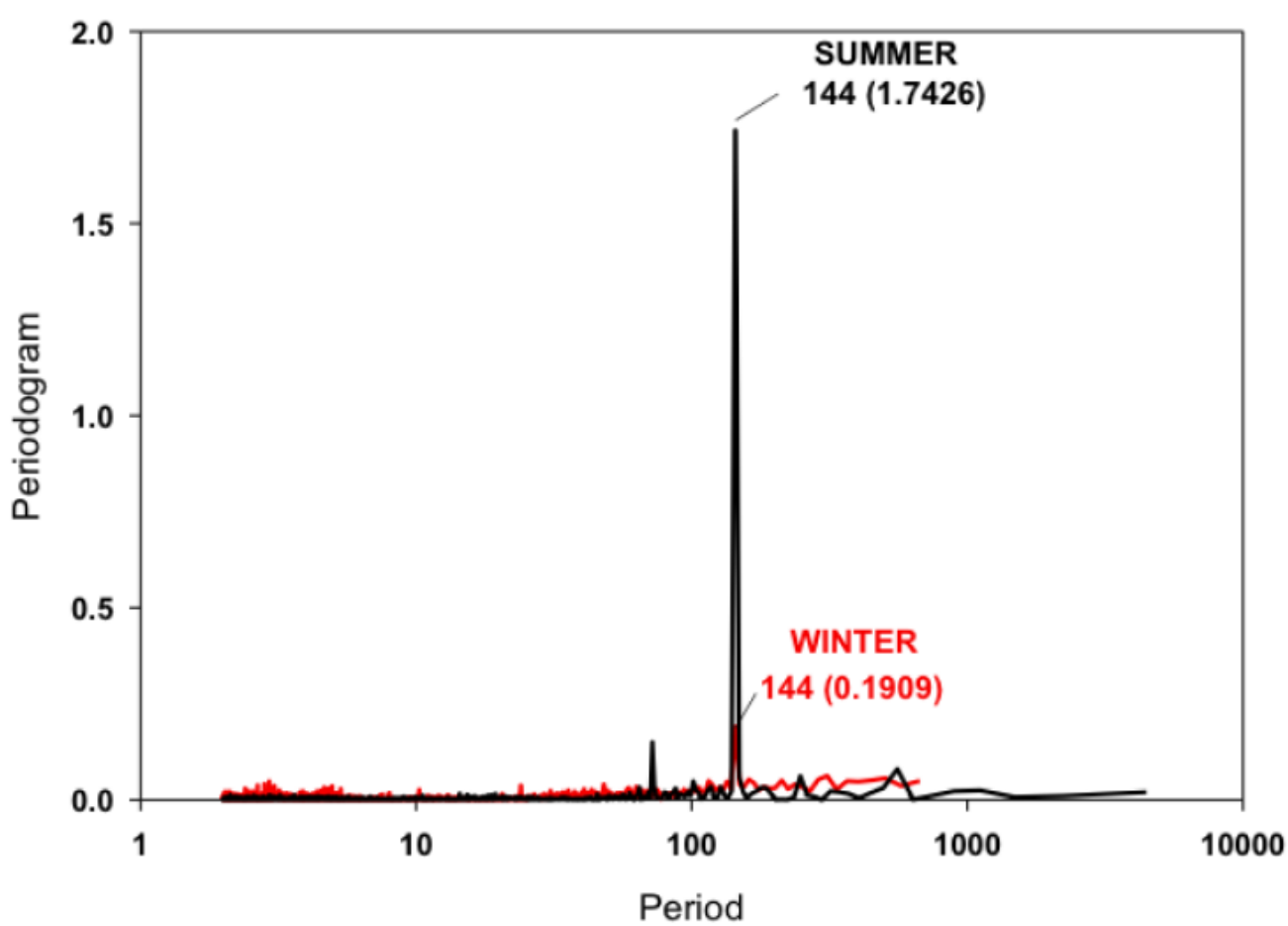

Figure 2. Spectral analysis of daily stage fluctuations at Cobb Mill Creek (Figure from Robertson, 2009). The period is the number of sample events at which autocorrelation is observed, and the "periodogram" represents the strength of the autocorrelation. Because samples were collected at 10-min intervals, the occurrence of the peaks at 144 indicates a strong signal that recurs exactly at 24-hr intervals (144 samples per day). The small winter signal (actually in March) is likely due to a few evergreen trees and some nondeciduous shrubs near the stream. Detrending of the data was done by the first difference method.

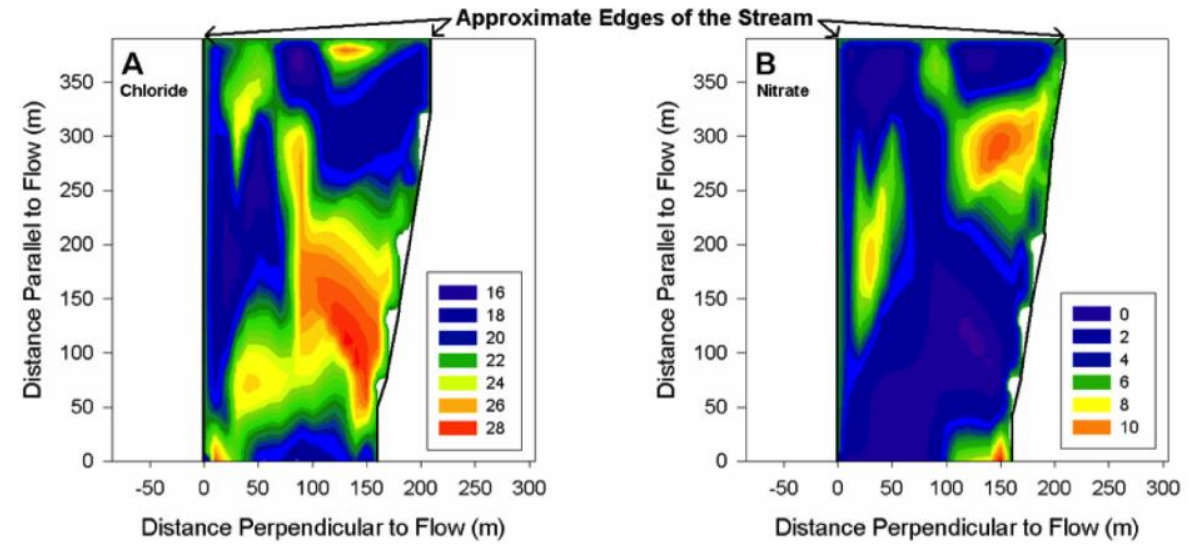

Figure 3. Map of chloride concentrations (A) and nitrate concentrations (B) in $\mathrm{mg} \mathrm{L}^{-1}$ in groundwater discharge from the streambed on 8/02/2007(Flewelling, 2009). 
Given the complex nature of groundwater and the unclear travel path of the groundwater at Cobb Mill Creek it is important that any possible spatial effects be taken into account. The occurrence of a diurnal fluctuation in streamwater $\mathrm{NO}_{3}{ }^{-}$concentration the center of the stream channel does not preclude, or assure, that the sides of the stream channel will also exhibit a diurnal pattern. Kennedy et al. (2009b) attributed the observed variance of $\mathrm{NO}_{3}{ }^{-}$ concentration in the streamwater to differing agricultural practices on each side of the stream. At the stream section of Cobb Mill Creek that will be the study location, there are highly different uses of the land immediately adjacent to the stream. The northeast borders an agricultural field used to grow corn and soybeans. The southwest side of the creek is exclusively a wooded residential property that abuts the stream. Due to these highly different land uses, it is possible that they could have a compounding effect on any evidence of diurnal variation in the streamwater. Are there differences in the $\mathrm{NO}_{3}{ }^{-}$concentrations of inseepage across the stream channel that might be due to differences in land use on either side of Cobb Mill Creek?

Rusjan et al. (2010) observed a seasonal variation of $\mathrm{NO}_{3}{ }^{-}$in the streamwater. This variation was attributed to the primary production uptake during periods of dormancy for the deciduous vegetation surrounding the stream. Summer samplings produced a diurnal variation in the streamwater $\mathrm{NO}_{3}{ }^{-}$concentration that was attributable to the surrounding forest and a shift was observed in the maxima and minima by up to six hours. This corroborates with the results reported by Robertson (2009). As indicated by Gribovszki (2008), the consumption of water by the vegetation surrounding streams, in temperate climates, has the greatest influence on streamwater. Will evapotranspiration and subsequent 
changes in the streamwater inseepage rates at Cobb Mill Creek result in diurnal variability in the $\mathrm{NO}_{3}{ }^{-}$concentration in the inseepage.

The present study undertook the examination of the connection between evapotranspiration and stream stage and $\mathrm{NO}_{3}{ }^{-}$concentration in the stream water by looking for diurnal patterns in inseepage similar to those observed for stream stage by Robertson (2009) and Flewelling et al. (2013). To undertake this task numerous water samples, stream and inseepage, were collected from a designated reach of Cobb Mill Creek. The water samples were collected over 10 days during June, 2010 at 6-hr intervals and for 3 days in September, 2010 at 2-hr intervals. The results obtained in June displayed a diurnal pattern in nitrate concentration in the stream water, but no pattern could be detected either in discharge or nitrate concentration in samples recovered from the seepage meters. In September, there was no diurnal pattern in $\mathrm{NO}_{3}{ }^{-}$ concentration in either the inseepage water or the stream water. Discharge and nitrate concentration in the inseepage water did vary spatially across the streambed. Stream stage during both months of sampling exhibited diurnal variation, although the September 2010 stream stage oscillations were dampened as compared with the June observations, and in September, the water level in the stream was several $\mathrm{cm}$ lower than in June. 


\section{Methods}

\subsection{Site Description}

The location of the sampling campaigns was Cobb Mill Creek, a second-order, groundwater dependent stream, which has flow year round along its length of $2.9 \mathrm{~km}$. It is located on the southern end of the Delmarva Peninsula on the property of the Anheuser-Busch Coastal Research Center, and it is $19 \mathrm{~km}$ north of the Chesapeake Bay mouth. The nearest town to the study location is the village of Oyster on the Eastern Shore of VA. The study site at Cobb Mill Creek is geographically located $37^{\circ} 17.45^{\prime} \mathrm{N}$ and $74^{\circ} 55.75^{\prime} \mathrm{W}$. The watershed covers approximately $5.0 \mathrm{~km}^{2} .50 \%$ of land use on Virginia's Eastern Shore was agricultural in 2000 (USDA, 2002) with $80 \%$ of these fields in row crops. Due to the highly permeable soils and shallow unconfined Columbia aquifer, much of the $\mathrm{NO}_{3}{ }^{-}$from fertilization (59\% synthetic and 35\% manure) easily and rapidly leaches into the groundwater (Denver et al., 2003). Within the Cobb Mill Creek watershed 62\% of the land is covered by forest and 34\% is in agriculture (Flewelling, 2009). Typical concentrations of nitrate in groundwater proximal to Cobb Mill Creek are in the range of $15-20 \mathrm{mg} \mathrm{NO}_{3}{ }^{-}-\mathrm{N} \mathrm{L}^{-1}$ while the streamwater there typically contains $1-2 \mathrm{mg} \mathrm{NO}_{3}^{-}-\mathrm{N} \mathrm{L}^{-1}$ (Mills et al., 2008).

\subsection{Sampling Campaigns}

Two separate sampling campaigns were conducted in the summer of 2010. The first campaign was in June, and it lasted for ten days with groundwater discharge samples collected every six hours at the base of the hillslope along a 20-m reach of the stream toward the Route 600 culvert. During each of the 40 sample sessions, a range of data was collected including stream stage (at 10-min intervals), groundwater discharge (at 6-hr intervals), and stream-water and groundwater inseepage for anions: $\mathrm{NO}_{3}{ }^{-}, \mathrm{NO}_{2}{ }^{-}$, and $\mathrm{Cl}^{-}$using seepage meters. 


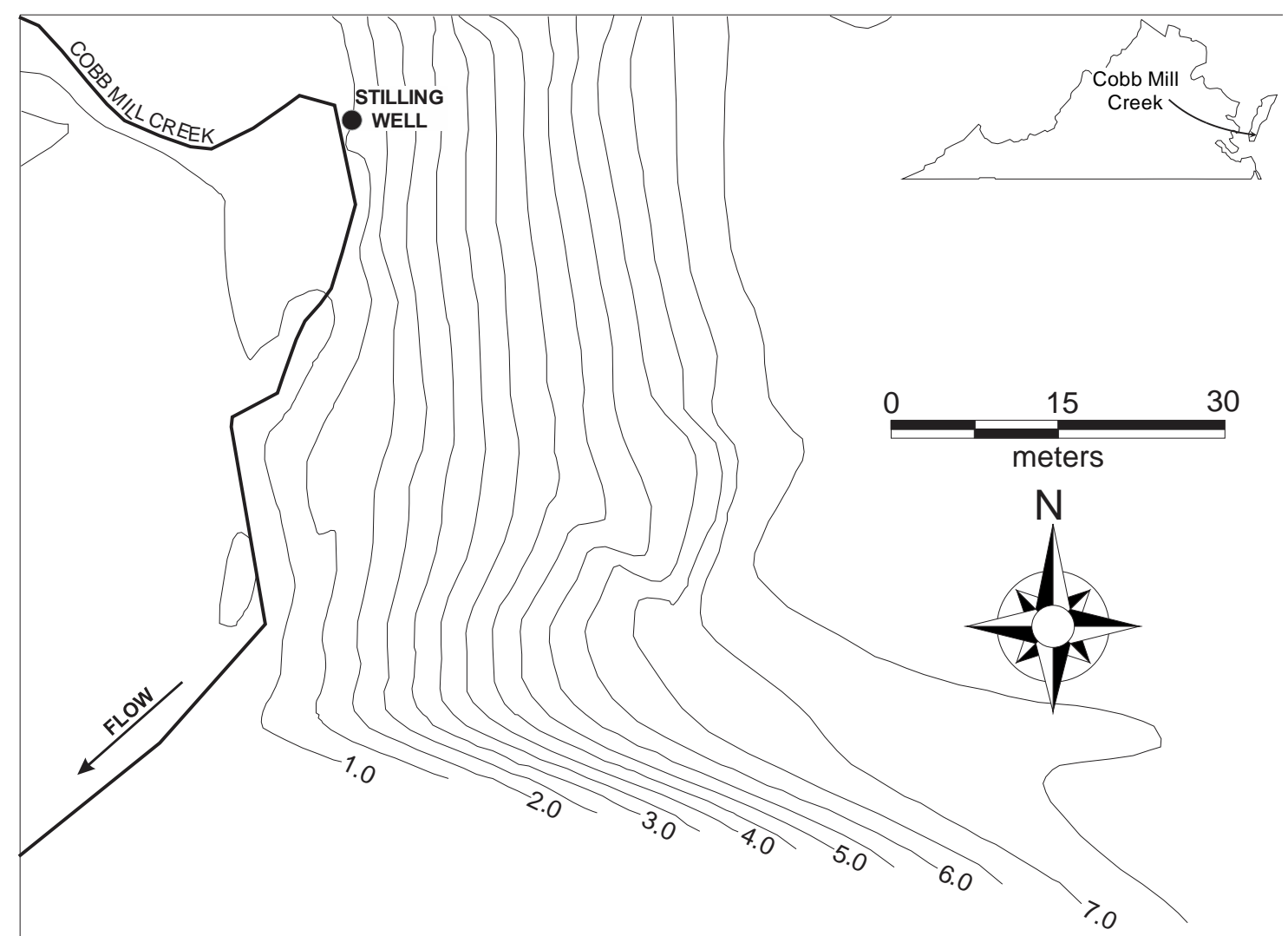

Figure 4. Site map of Cobb Mill Creek on Virginia's Eastern Shore. Elevation units are meters above mean sea level.

Nine seepage meters (described below) were spaced 2.4 meters apart along the centerline of the stream (Figure 5). At locations 2, 5, and 8, additional seepage meters were placed on either side of the center meter. An ISCO automated sampler was set up on the bank of the creek with the inlet tubing attached to a stake located near the first (most downstream) seepage meter.

In early September, an additional three-day sampling campaign was undertaken with a sampling frequency as above except that inseepage (groundwater discharge) was measured and sampled for chemical analysis every two hours. In the September session, seepage meters were set up downstream of the initial campaign locations and clustered in two sets of three (Figure 5). Each set of meters was spaced evenly across the width of the stream and parallel to the second set of meters. The distance between the two sets was approximately 1 
meter. A board was placed across the stream between the two sets of meters. Sampling the meters from the board limited the disturbance to the streambed surrounding the meters during sampling. The ISCO sampler was located in same place as the first sampling campaign, which was upstream of the seepage meters by approximately 6.5 meters.

\subsection{Sample Collection and Processing}

During both campaigns, 500-mL water samples were collected hourly from the stream reach with an ISCO sampler, beginning at noon on the first day of the investigation. Samples were retrieved from the sampler every $24 \mathrm{hr}$ and filtered $(0.45-\mu \mathrm{m}$ pore size $)$ and frozen for return to the laboratory. The samples were kept frozen at $-18^{\circ} \mathrm{C}$ until they were thawed for the determination of $\mathrm{NO}_{3}{ }^{-}$by ion chromatography (IC). The concentration data were plotted against time to compare with the stream-stage data.

Stage measurements are collected routinely at the site at 10-min intervals using pressure transducers (Solinst Levellogger®). A time-series analysis (spectral decomposition (Box et $a l ., 1994)$ ) was used to determine the frequency of periodic variation during the 10-day sampling (see Figure 2 for an example) for both stream stage and $\mathrm{NO}_{3}{ }^{-}$concentration. Time series analysis was performed using the Spectral Analysis routine available in the Forecasting module of SPSS ${ }^{\circledR}$ v. 20. In the present study, if detrending of the data was necessary due to generally increasing or decreasing slopes, a trend function (e.g., a quadratic equation) was fit to the data, and then the value predicted by the function at a given point was subtracted from the measured datum to remove the trend from the signal.

Seepage meters (described below) were organized in the streambed with 9 meters down the center of the stream and at meter-locations 2,5 and 8 , an additional meter was placed on each side of the center meter (Figure 5). All seepage-meter condoms were collected every 6 hours during the 10-day campaign in June and every 2 hours during the 3 -day campaign in 


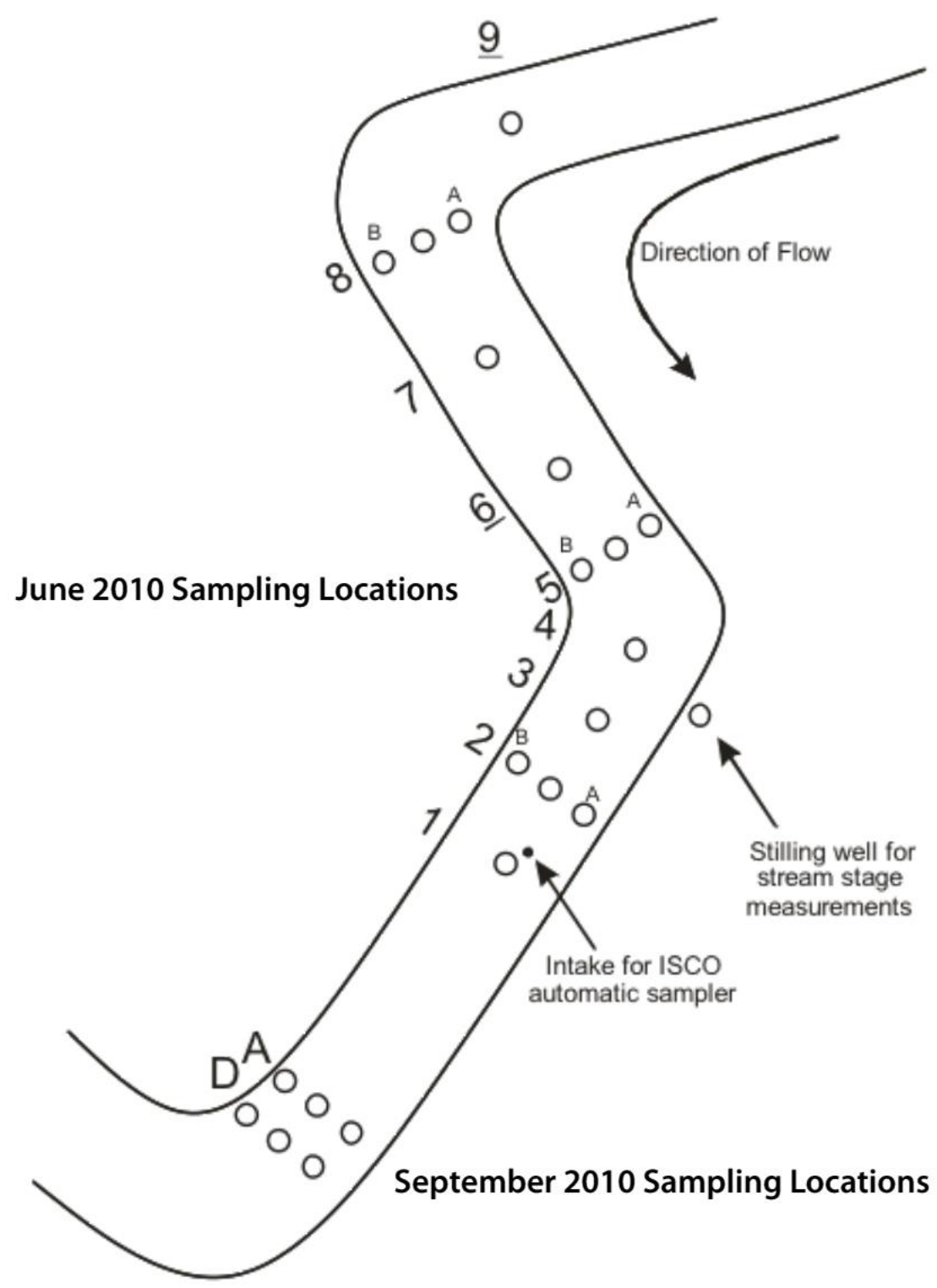

Figure 5. Location and arrangement of seepage meters at the hillslope at Cobb Mill Creek in June and September (not to scale). Also shown are the location of the stilling well for obtaining stage measurements and the intake of the ISCO sampler where stream water samples were collected hourly. 
September to measure the accumulated discharge and to provide sample for the determination of $\mathrm{NO}_{3}{ }^{-}$concentrations in the water discharging from the stream sediment.

The discharge rate of groundwater into the stream was estimated by recording the volume of water collected in the condom attached to each seepage meter over each period of time. The volume of water was determined by drying the outer surface of the condom with paper towel and then weighing the water-filled condom, and subtracting the average weight of a condom $(2.25 \mathrm{~g})$. The average condom weight was achieved by weighing three random acid washed and DI rinsed condoms (see below). After the condom was weighed, the water collected in the condom was frozen at $-18^{\circ} \mathrm{C}$ and returned to the laboratory for analysis of $\mathrm{NO}_{3}{ }^{-}$by ion chromatography.

\subsection{Seepage Meters}

Two types of devices were used to measure the discharge of seepage across the sedimentwater interface. The primary device was patterned after the designs of Lee (1977) and Lock and John (1978) as modified by Flewelling et al. (2012). Lee's meters were originally designed for measurement of inseepage to lakes and were made from the ends of 55-gallon drums to provide a contained seepage face of a large cross-sectional area. Given the higher seepage rates expected in this gaining stream, the seepage meters used here consisted of $10-\mathrm{cm}$ diameter metal cans cut to a length of $7 \mathrm{~cm}$ (Flewelling et al., 2012). A single hole was drilled into the end of the can near the edge through which a barbed fitting / tubing connector was attached. The meters were pressed into the sediment deep enough to leave a minimal amount of volume above the sediment surface (usually slightly less than a centimeter depth).

The meters were allowed to sit in place for at least 24 hours to allow stream water that was trapped inside the meter during its placement to exit prior to sealing the meter with the condom. The barbed fitting allowed for the attachment of a latex condom to receive water 
displaced from the meter due to inseepage (Figure 6). Latex condoms were prepared for field use by washing in $10 \% \mathrm{HCl}$, then by several tap water rinses, and three thorough rinses in deionized water as described by Flewelling et al. (2012). The latex condom was rolled tightly to expel air and to prevent stream water from entering while it was being attached to the hose barb that was the outlet to the meter. The open end of the condom was placed over the hose barb, and the condom was secured to the hose barb with a twist-tie before allowing the condom to unfurl. Subsequently, water entering the meter from the sediment was displaced into the condom. The condom presented no resistance to seepage as long as the latex had not begun to expand (i.e., stretch), in fact, Koopmans and Berg (2011) demonstrated that the condoms actually exert a tiny suction $(\Delta \mathrm{h}<0.1 \mathrm{~mm})$ that can barely be distinguished.

Preliminary studies indicated that the maximum volume that could be held in the condom before the latex began to stretch was about $140 \mathrm{~mL}$. Thus, we considered the largest acceptable volume trapped in the condoms while deployed to be $125 \mathrm{~mL}$. Only a very few volumes greater than that were ever obtained.

\subsection{Chemical Analysis}

Each water sample was thawed immediately prior to analysis. A Dionex Ion Chromatograph ICS-2100 was used to analyze all of the water samples for $\mathrm{NO}_{3}{ }^{-}$. An automated sampler (Dionex AS-DV) was connected to the IC for 50-sample batch processing. The sample sequences used to run the IC and autosampler were programmed using the Chromeleon Software version 6.8. The IC was programmed to run at a column temperature of $35^{\circ} \mathrm{C}, 1 \mathrm{~mL} \mathrm{~min}{ }^{-1}$ flow rate, $34 \mathrm{mM} \mathrm{KOH}$ eluent concentration, $90 \mathrm{~mA}$ suppressor current, and a runtime of 15 minutes. The column was a 4-mm Dionex AS18. At the start of each run sequence, a blank sample of deionized water was run to set the baseline for the sequence. The blank was followed by a set of mixed standards that contained each of 
the anions of interest. For the samples from the June sampling campaign, the six standard concentrations ranged from 0.2 to $25.0 \mathrm{NO}_{3}{ }^{-} \mathrm{N}$. While the eight standard concentrations for the September campaign ranged from 0.02 to $11.5 \mathrm{NO}_{3}{ }^{-} \mathrm{N}$. The standard concentrations used in the second sampling campaign were selected on the basis of prior knowledge of observed ranges and the prior determination of IC detection limits. Occasionally $\mathrm{NO}_{2}{ }^{-}$peaks appeared in the chromatogram. When they did, the samples were tested with reagents used for the colorimetric determination of $\mathrm{NO}_{2}^{-}$(Montgomery and Dymock, 1961). Even with IC peaks showing substantial amounts of $\mathrm{NO}_{2}{ }^{-}$present, no $\mathrm{NO}_{2}{ }^{-}$could be detected with the colorimetric test. The presence of the $\mathrm{NO}_{2}{ }^{-}$peaks cannot be explained, but strong evidence

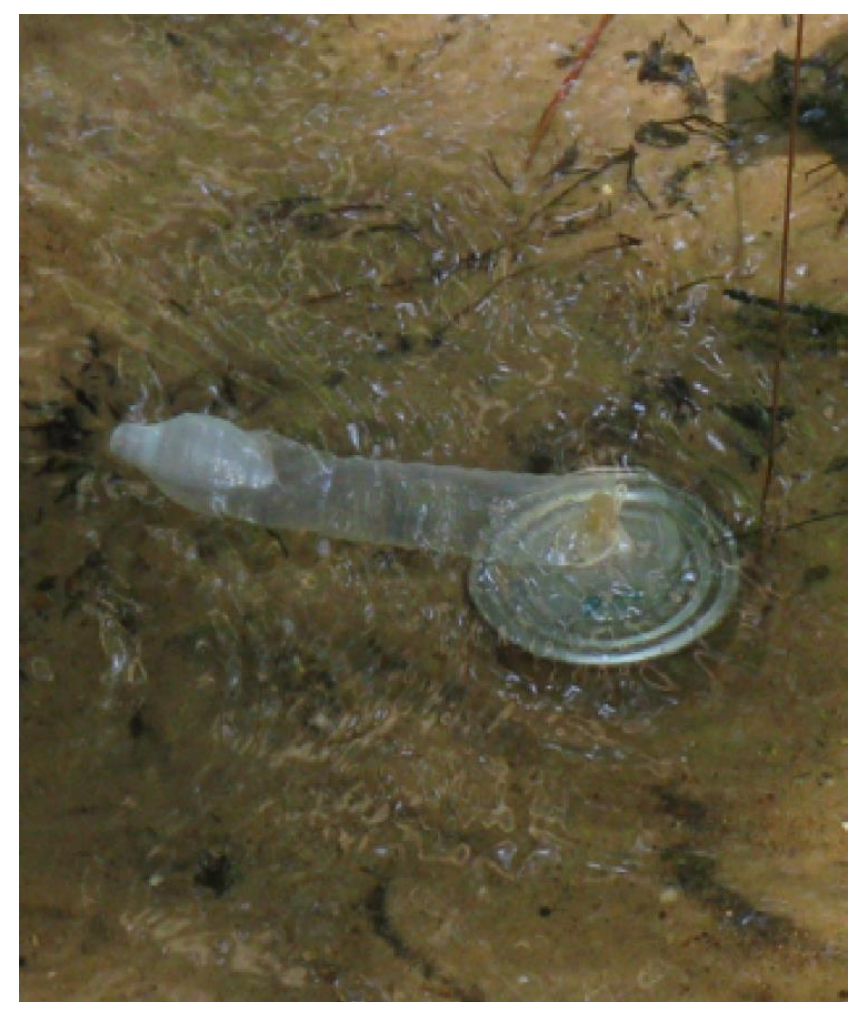

Figure 6. A deployed seepage meter. The can is $10 \mathrm{~cm}$ in diameter and $7 \mathrm{~cm}$ long. The can is pressed into the sediment such that no more than $1 \mathrm{~cm}$ extends above the sediment surface. 
suggests they were not $\mathrm{NO}_{2}^{-}$. Thus, $\mathrm{NO}_{2}^{-}$was considered not to be present in any of the samples and no results for $\mathrm{NO}_{2}{ }^{-}$are reported.

Each sample was analyzed once under identical analytical conditions, but random duplicates and triplicates were included sporadically to confirm the consistency of the IC analysis. Each anion standard was compared with the corresponding standard from the previous run and the $\mathrm{R}^{2}$ value for each set of standards was checked at the end of each run. The $\mathrm{R}^{2}$ values ranged from 0.9994 with the first June samples to 0.9949 with the last September samples.

\subsection{Sediment pore water samples}

During the September sampling campaign pore water samples were collected with a small probe at three depths: 5, 10 and $20 \mathrm{~cm}$ each time seepage meters were collected. The probe was a side discharge needle about $30 \mathrm{~cm}$ long with a round tip as described by Berg and McGlathery (2001). The pore water samples were handled and processed using the same methods established for samples from the seepage meters. 


\section{Results}

\subsection{Diurnal variation in stream stage and $\mathrm{NO}_{3}{ }^{-}$concentrations}

\subsubsection{0-day Campaign (June)}

The stream stage for the June sampling campaign (Figure 7) displayed a clear diurnal signal for most of the period of observation, although there was some high frequency noise in the data obtained from the pressure transducers. The two days prior to the onset of sampling saw some precipitation which raised the overall stream level; the 13 th had 0.4 inches of precipitation and the 14 th had 0.49 inches of precipitation (http://www.wunderground.com/weatherstation/WXDailyHistory.asp?ID=KVAWEIRW1). As a result, a flood wave was seen in the first 2 days of the stage hydrograph, and the recession of that wave was evident during the first few days of the June study. Diurnal

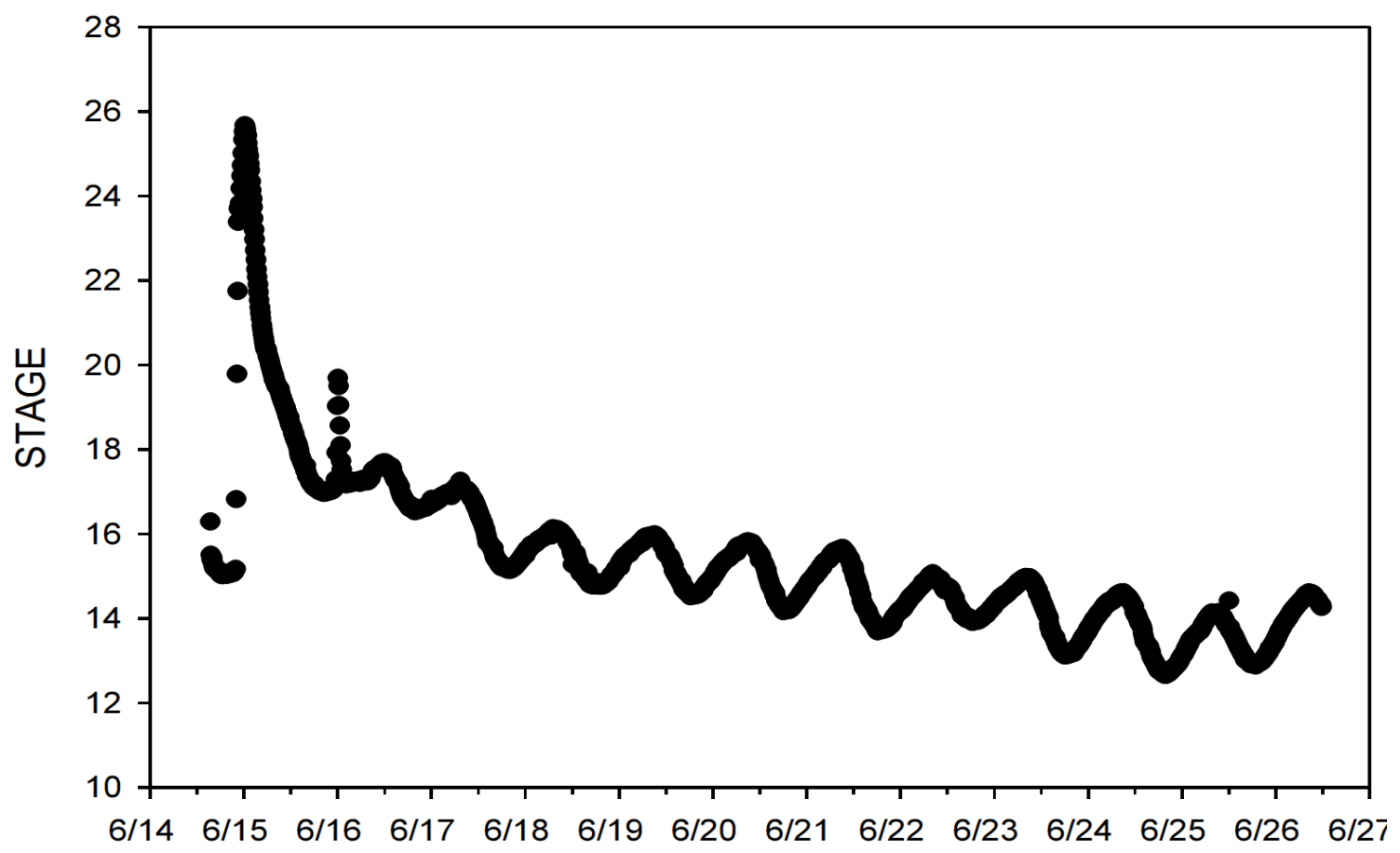

Figure 7. Relative stage (in cm, not corrected to sea level) at the hillslope of Cobb Mill Creek during the 10-day experimental period in June, 2010. The storm hydrograph for the rain occurring in the early morning of June 13 (the day before the onset of the actual observations) 


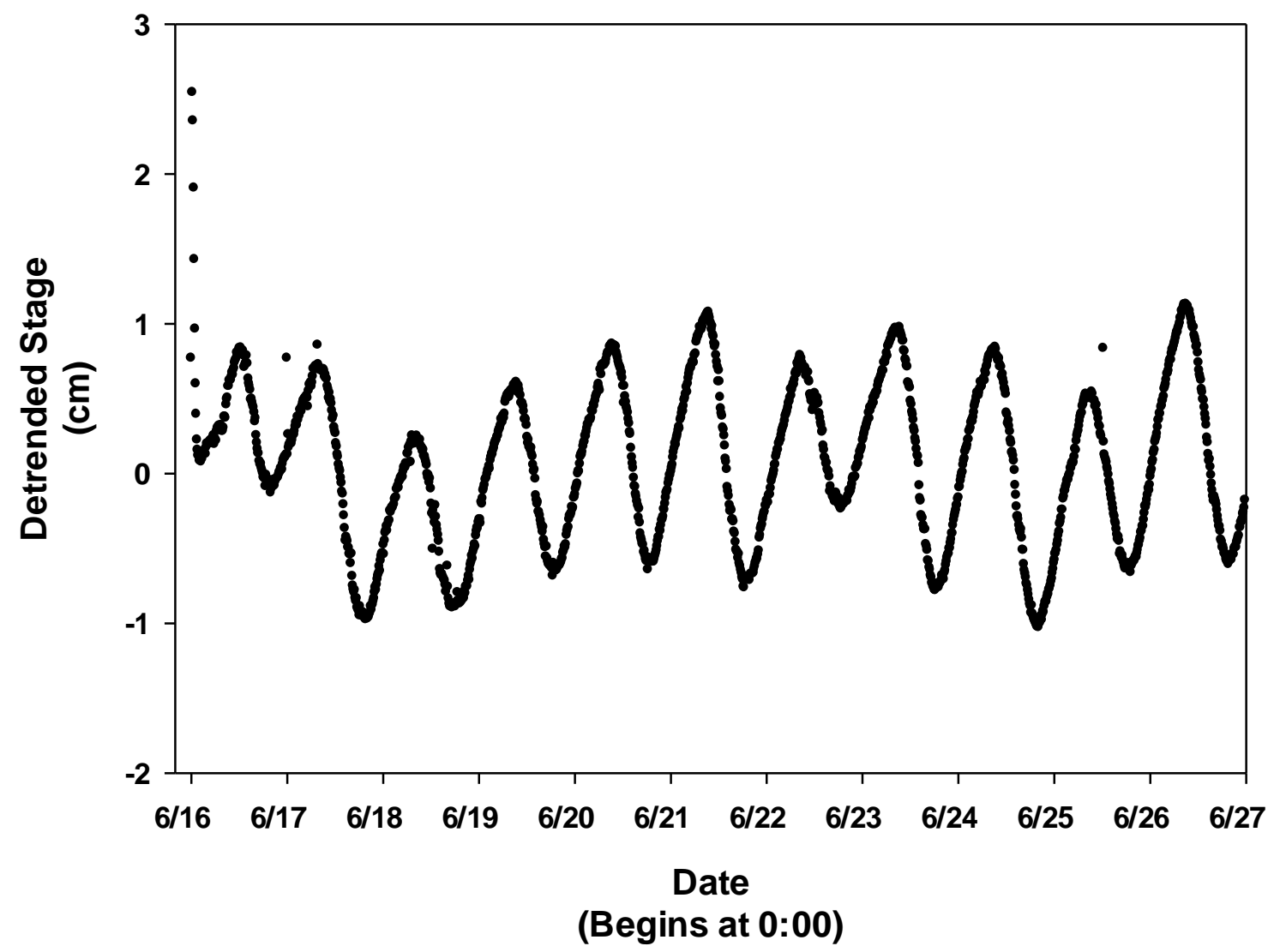

Figure 8. Variation in stream stage over the 10-day observation period after detrending (in this case by subtracting a quadratic function from the dataset.

fluctuations were apparent after the first two days, and the stage continued to decline slightly over the remaining days of observation. The data were detrended by fitting a quadratic equation to the data, and then subtracting the values predicted by the equation from the corresponding measured data at each measurement point to yield the curve seen in Figure 8.

The storm at the beginning of the observation period injected some noise into the detrended signal (Figure 8), but that noise did not obscure a strong lag observed at 144 samples (Figure 9), corresponding to a period of exactly 24 hrs $(6$ samples per hour $\times 24$ hours).

Samples for anion analysis, particularly $\mathrm{NO}_{3}{ }^{-}$, were taken hourly for the entire campaign 


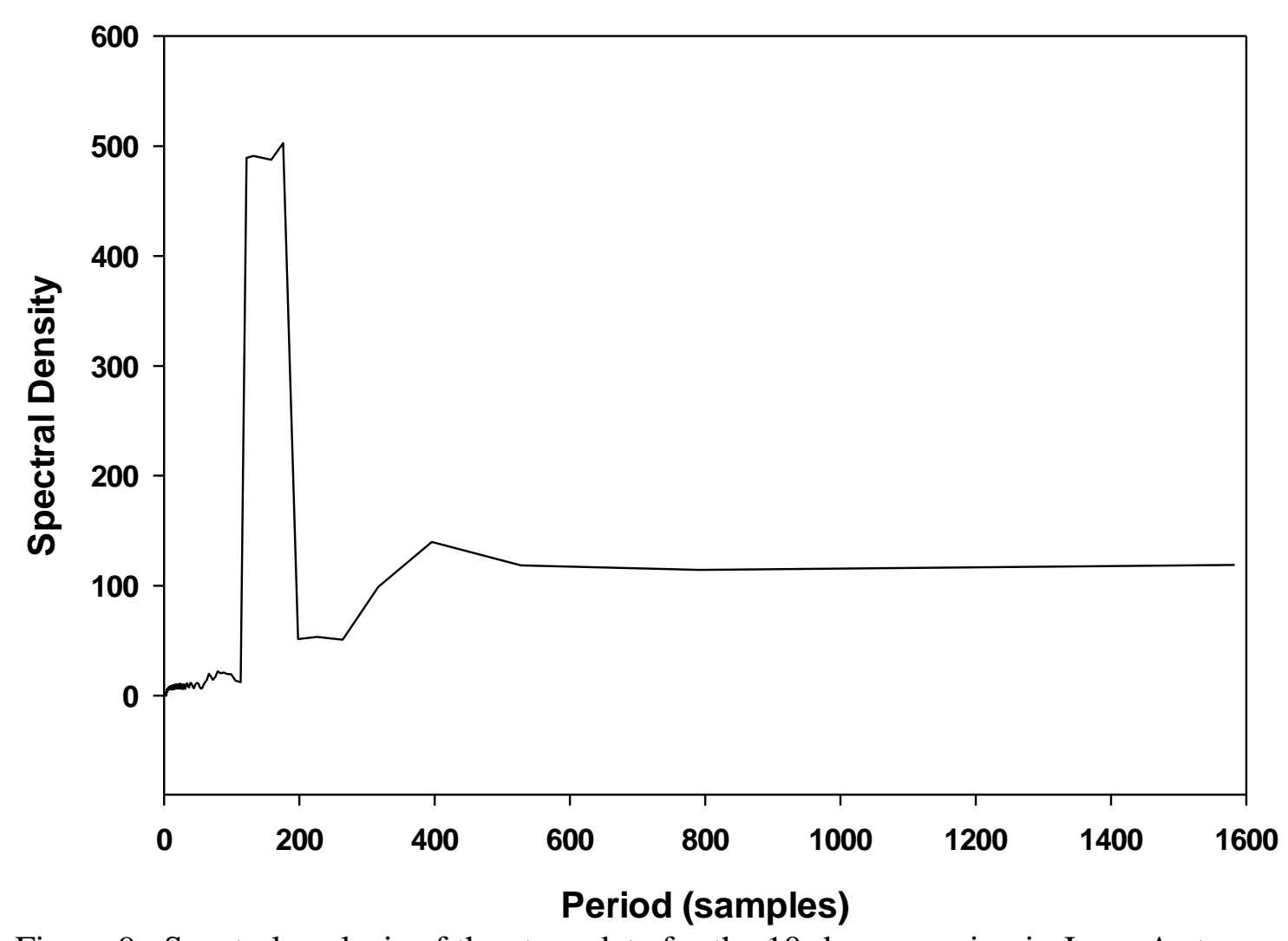

Figure 9. Spectral analysis of the stage data for the 10-day campaign in June. A strong (but broad) peak is apparent that is centered on 144 samples representing autocorrelation with a 24-hr lag.

with an ISCO autosampler. A clear signal similar to the stage record was not seen; nevertheless, a diurnal pattern was evident that fluctuated around an average of $3 \mathrm{mg} \mathrm{NO}_{3}^{-}-\mathrm{N} \mathrm{L}^{-1}$ (Figure 10). During the period of observation, many samples had $\mathrm{NO}_{3}{ }^{-}$concentrations that fell substantially below the average range of fluctuations. All samples that did not conform to the expected pattern, and a random selection of samples that did "fit" the expectations, were re-analyzed for $\mathrm{NO}_{3}{ }^{-}$, and the reanalysis of the samples confirmed the $\mathrm{NO}_{3}{ }^{-}$values originally obtained. These results are presented in Figure 10 in their entirety. The diurnal pattern increased in prominence over the course of the observation period. The number of samples that had $\mathrm{NO}_{3}{ }^{-}$concentrations less than the $\mathrm{NO}_{3}{ }^{-}$concentration of the diurnal troughs was 


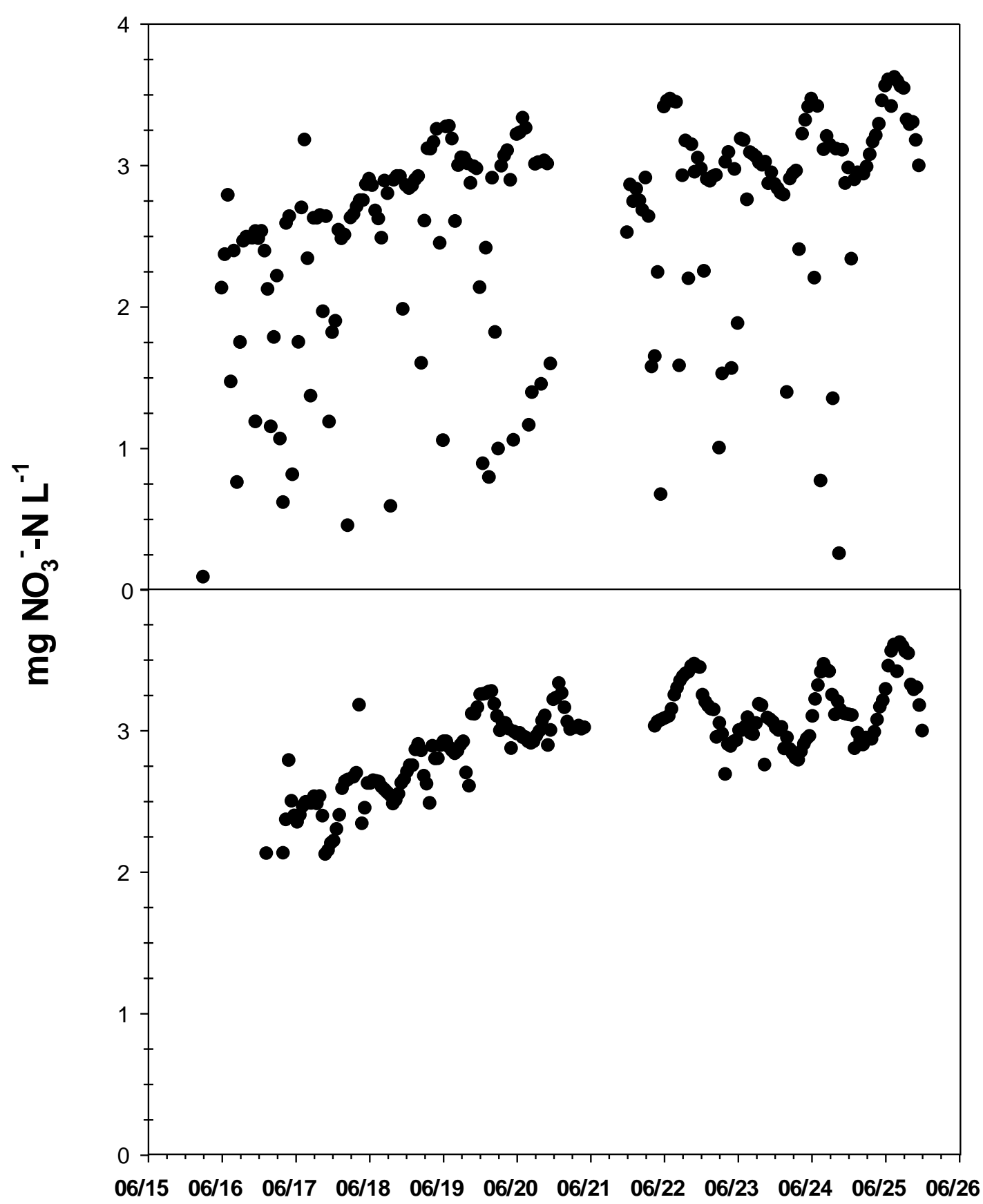

Figure 10. Concentration of $\mathrm{NO}_{3}{ }^{-} \mathrm{N}$ in stream water samples taken hourly in Cobb Mill Creek. The upper panel represents the uncorrected raw data. The lower panel represents the same data after filtering the very low values thought to arise from sample contamination. Malfunction of the automatic sampler prevented sample collection from $12: 00$ on $6 / 21$ to $11: 00$ on $6 / 22$ 
noticeably fewer. It is possible that the low $\mathrm{NO}_{3}{ }^{-}$concentrations in many of the samples could be due to the rainstorm that occurred the night before the onset of sampling. While this idea is neither confirmed nor contradicted by the results, a more likely cause for the low values is contamination of the samples with water that did not contain $\mathrm{NO}_{3}{ }^{-}$. Given that all the "outliers" were lower in concentration than the majority, and that most of the outliers were single-point aberrations, spectral analysis was done on the data set in which the aberrant values were replaced by the mean value of the sample taken immediately prior to and after the questionable sample (Figure 10, lower panel). The range of $\mathrm{NO}_{3}{ }^{-}$concentrations in the samples was small, but the results showed visible periodicity. Because of the gap in the data record caused by malfunction of the automated sampler, spectral analysis of the entire data set was not possible. However, the analysis was applied to the portion of the data that was collected after the malfunction. Because the data did not appear to trend either up or down, no detrending was applied. The spectrum showed a peak of sorts (Figure 11), but it was quite broad, likely due to the noisy data obtained. The peak was notable at 24 samples. Given that samples were taken once an hour, that yields a lag time of $24 \mathrm{hr}$., however there was also a large amount of spectral density at much longer periods, including ones well beyond the duration of the data record.

\subsubsection{3-day campaign (September)}

The 3-day campaign in September yielded results (Figure 12) that differed somewhat from those obtained in June, but the same general patterns were observed during both sampling periods. The water level was substantially lower than recorded in June (average for September was approximately $11.2 \mathrm{~cm}$ above datum as opposed to about $15 \mathrm{~cm}$ in June), and the magnitude of the fluctuation was less than a centimeter as opposed to the $3-\mathrm{cm}$ range observed in June. Despite the shortness of the record and the small variation in stage, spectral 
analysis of the stage data again showed a very strong signal at 144 samples ( $24 \mathrm{~h})$ (data not shown).

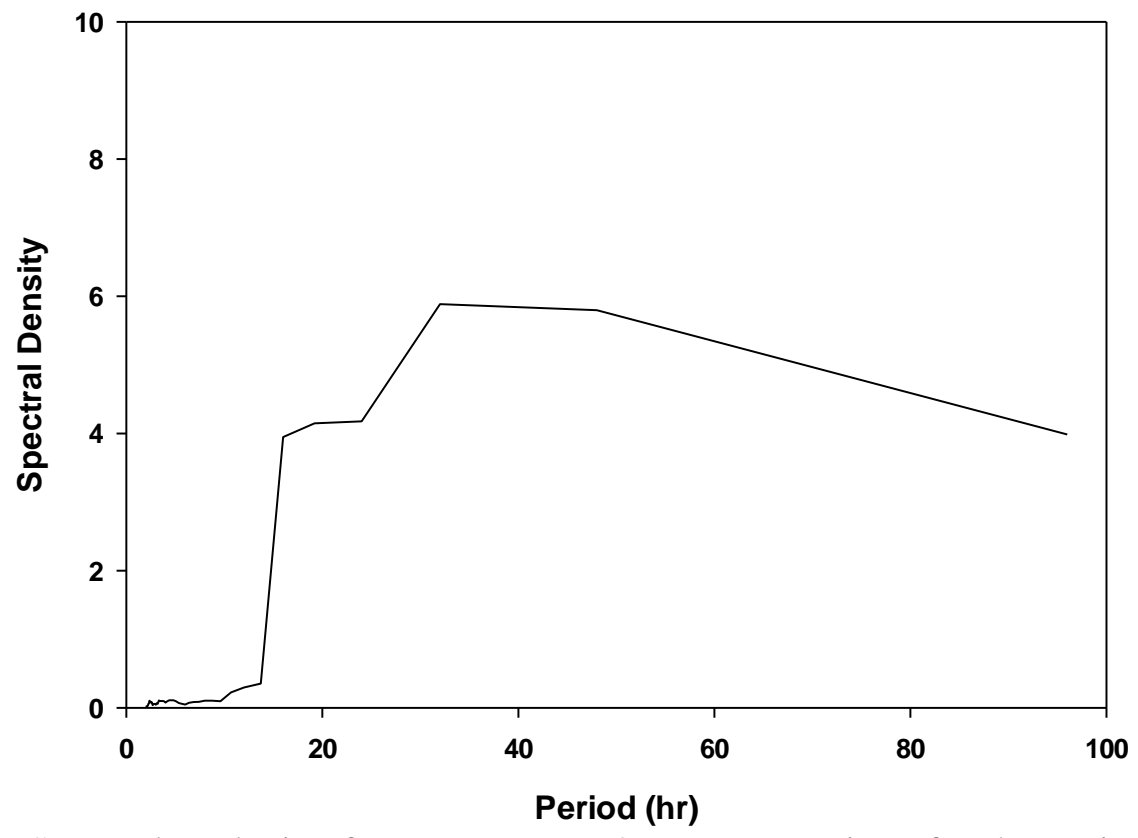

Figure 11. Spectral analysis of streamwater $\mathrm{NO}_{3}{ }^{-}$concentrations for the period from $6 / 21$ to $6 / 25$, when the effect of the storm just before the sampling period was no longer felt. Detrending was not applied to these data

Concentrations of $\mathrm{NO}_{3}{ }^{-}$were higher in September than those observed in June, and fluctuations were less evident (Figure 13). The anomalously low numbers were again present in the occasional sample, but because of the very small range of values of concentration for most of the samples analyzed, filtration provided no improvement in the ability to detect fluctuations. The mean value of the raw (unfiltered) data was $5.687 \mathrm{mg} \mathrm{NO}_{3}^{-}-\mathrm{N} \mathrm{L}^{-1}$ with a standard deviation of $0.786 \mathrm{mg} \mathrm{NO}_{3}^{-}-\mathrm{N} \mathrm{L}^{-1}$.

\subsection{Measurement of inseepage from Cobb Mill Creek sediment}

\subsubsection{0-Day Campaign (June)}

During the June campaign, seepage meter measurements in the various meters displayed a variety of patterns, but strong, periodic patterns were not obvious (Figure 14). Overlay of 


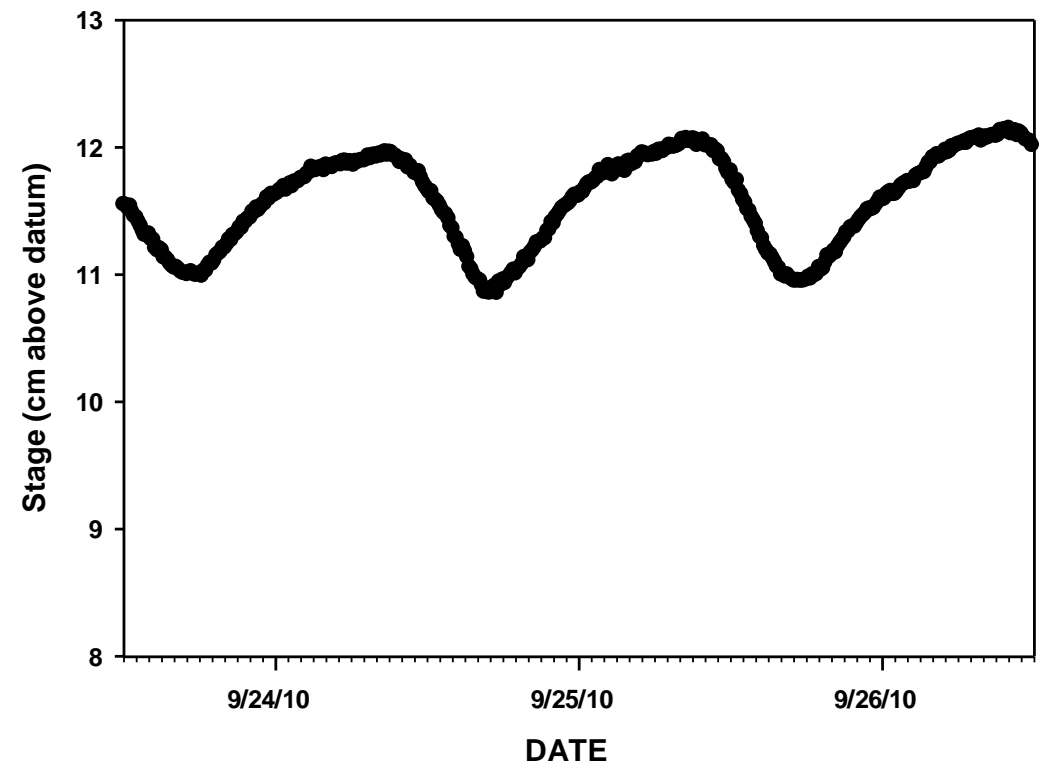

Figure 12. Stage in Cobb Mill Creek during the 3-day campaign in September. Data were excised from a longer record collected by our research group and maintained as part of the VCR-LTER database. Note that in this case, the record begins at noon on 9/23 and continues to 11:50 on 9/26. Spectral analysis of the data yielded a strong peak at a $24-\mathrm{h}$ lag time with a smaller secondary peak at $12 \mathrm{hr}$.

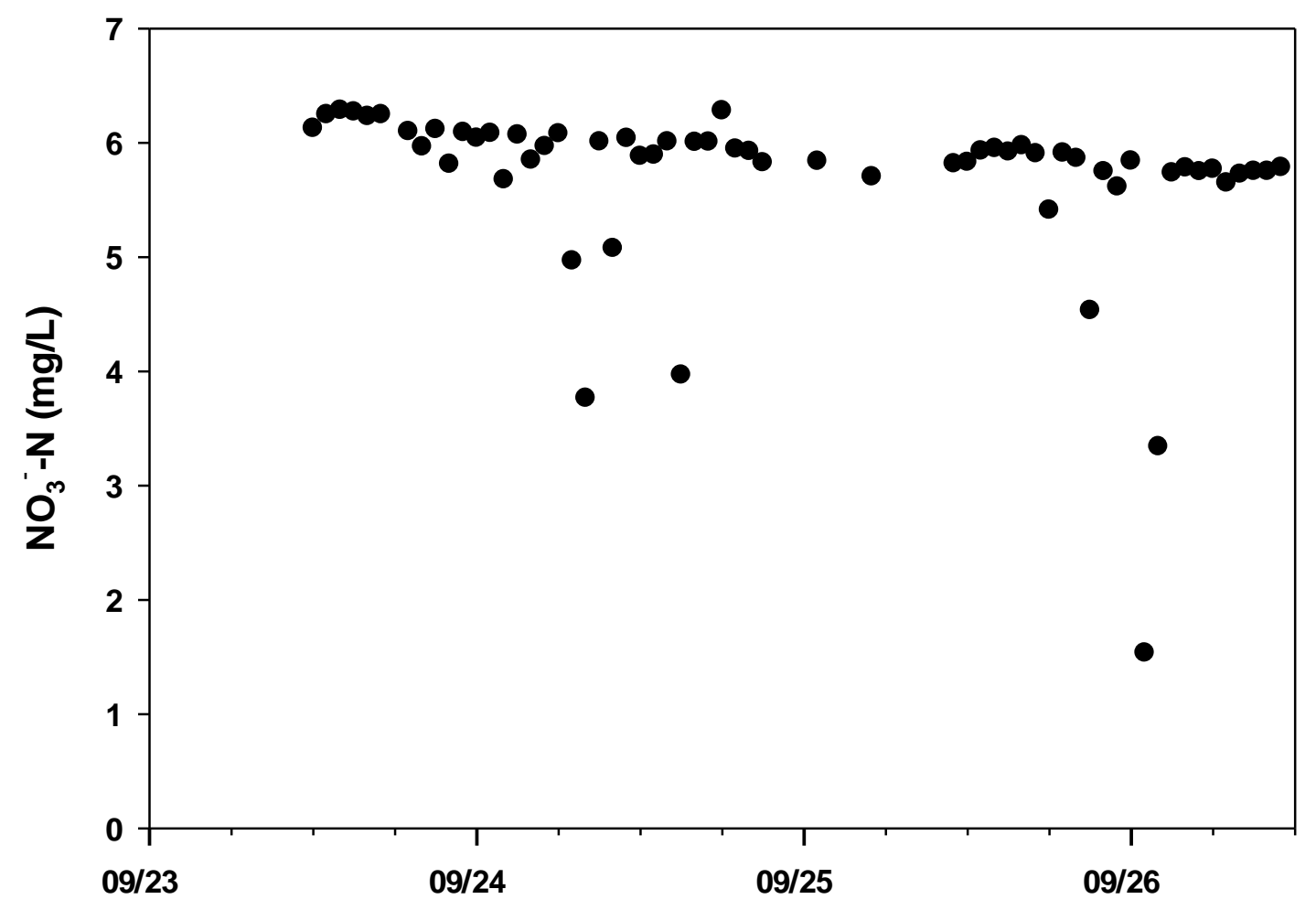

Figure 13. $\mathrm{NO}_{3}{ }^{-}$concentration in stream water collected hourly during the September 2010, 3-day campaign. Data are unfiltered, unlike those presented for the 10-day campaign Figure 10). Note the occurrence of a few anomalously low values in the record, similar to those seen in the June data. 


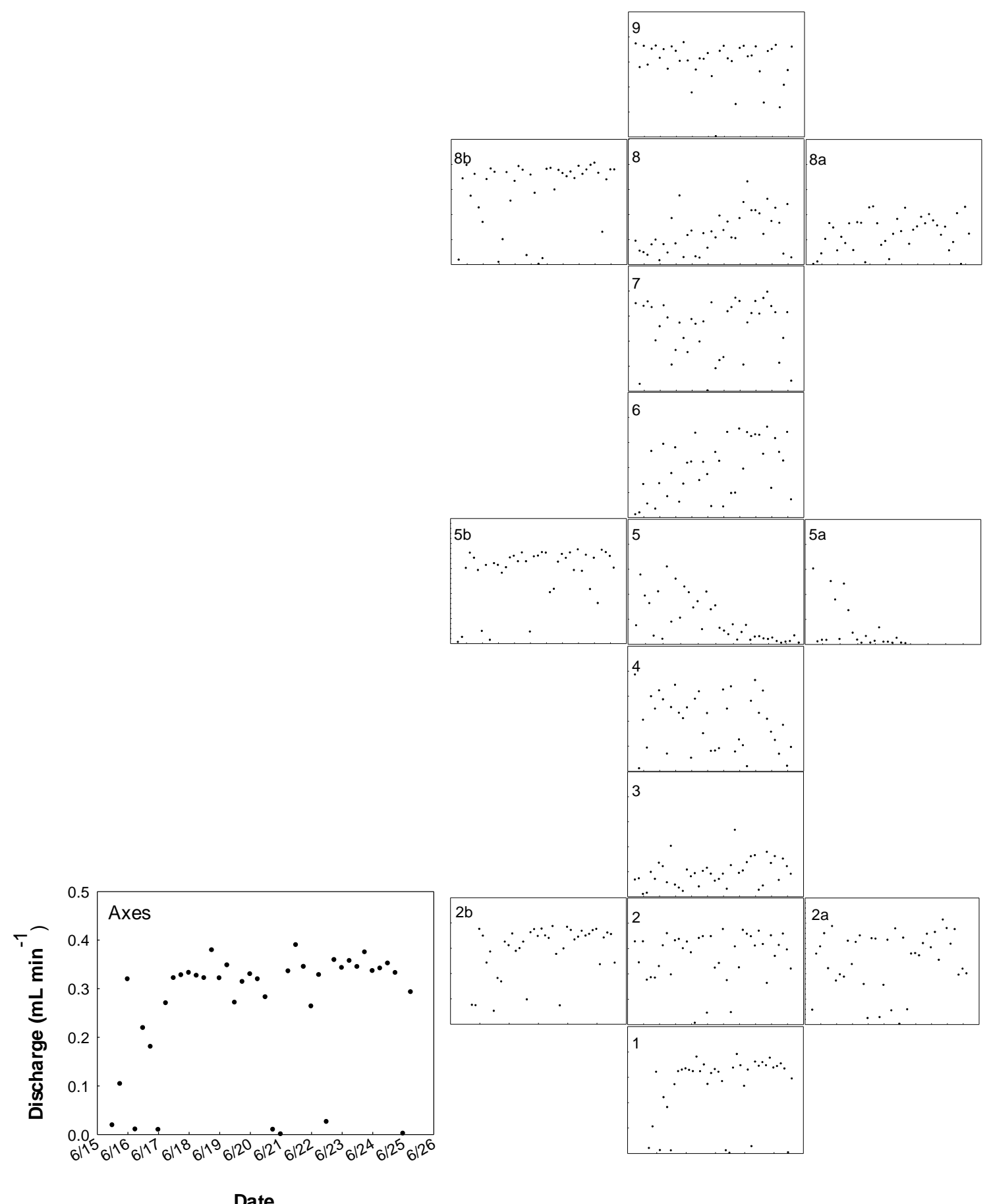

Figure 24. Groundwater discharge into the seepage meters placed in Cobb Mill Creek in June, 2010. The arrangement of the plots depicts the general arrangement of the meters throughout the stream reach (see Figure 5). Note that the individual graphs and data are contained in Appendix A1-A15. The axes of the plots are all identical and are depicted at the lower left of the figure 
a line with a perfect period of 24 hours shows that no such pattern in the data could be discerned for seepage meter SM 1 (Figure 15). Most of the meters yielded a similar pattern, there was variance in the amount of seepage obtained at different times, but a diurnal signal in the seepage pattern was not obvious. Discharges ranged from 0 to $0.4 \mathrm{~mL} \mathrm{~min}^{-1}$, although the most common readings were about $0.3 \mathrm{~mL} \mathrm{~min}^{-1}$. Some locations (e.g., SM 6) yielded almost random results over the entire range of values, whereas in others (e.g., SM 1, 2, 2a, and $2 b$ ), most values were in a very tight range with a few values substantially lower than those typically recovered. In some cases, seepage decreased substantially through the observation period (SM 5 and SM 5a) such that seepage was at or near zero for the last 3 to 4 day. However, measured seepage in SM 5b did not decrease with time, and it remained at around $0.33 \mathrm{~mL} \mathrm{~min}^{-1}$ during the entire period, recognizing that occasionally little seepage was measured, similar to observations in many of the other meters.

\subsubsection{3-Day Campaign (September)}

Discharge into seepage meters deployed in September at a location around $10 \mathrm{~m}$ downstream from that used in June also showed no periodicity (Figure 16). Samples were collected with higher temporal resolution ( $2 \mathrm{hr}$ ) as compared with the June effort ( $6 \mathrm{hr})$. Nevertheless, obvious diurnal patterns could not be seen. Discharge was generally greater in the September sampling. In June, the highest discharge obtained was around $0.4 \mathrm{ml} \mathrm{min}^{-1}$, whereas in September, four of the six meters deployed showed some values around or exceeding $0.8 \mathrm{~mL}$ $\min ^{-1}$. As seen in Figure 17, those were the meters on the left side of the stream (A, B, D, E). Given the lower stream stage in September $(c a .11 \mathrm{~cm})$ as compared to June $(c a .15 \mathrm{~cm})$, it is not clear if the differences in discharge were related to season or to location in the stream. 


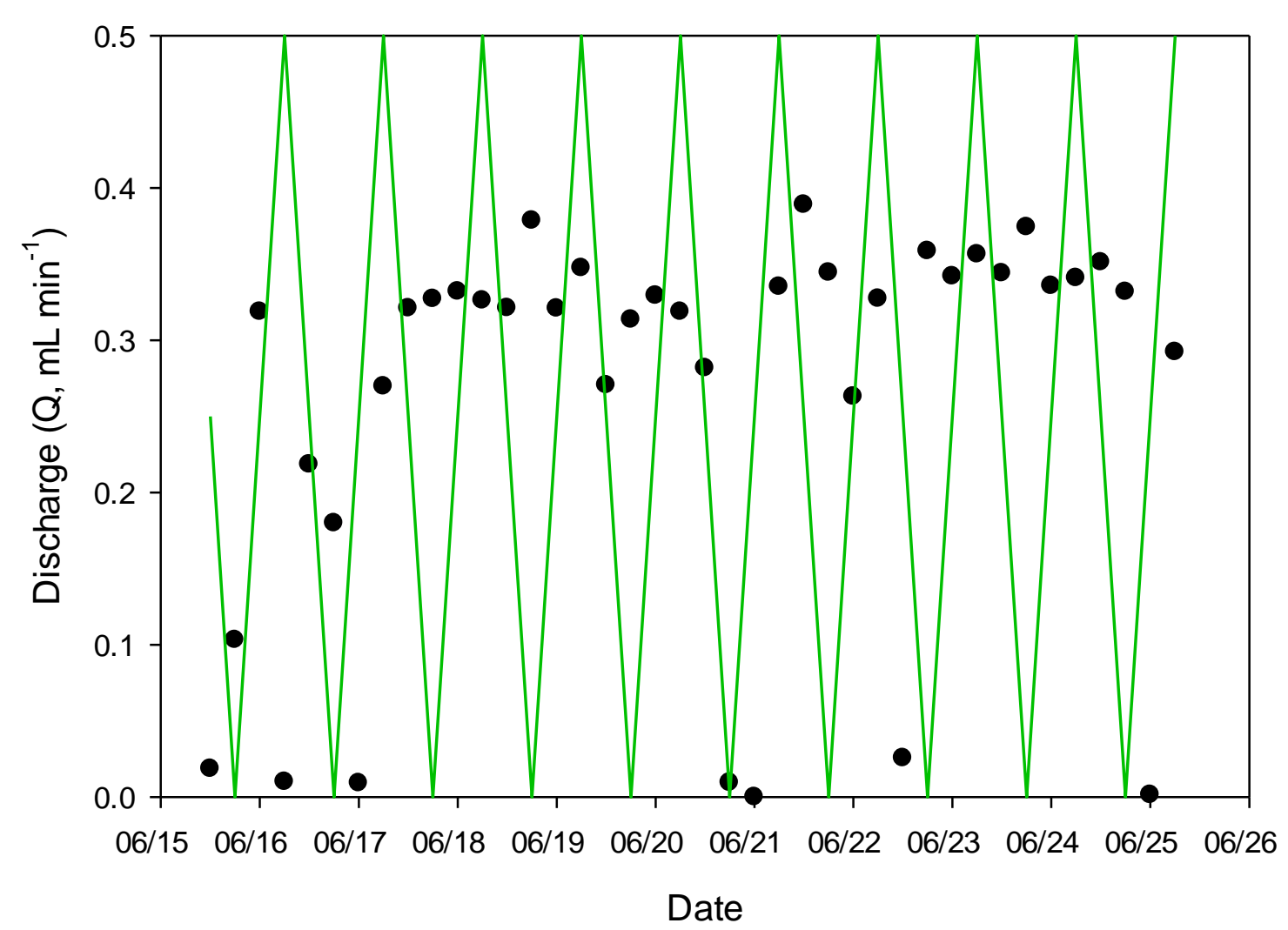

Figure 15. Discharge (volume collected / collection period [i.e., $6 \mathrm{hr}$ ]) in seepage meter 1 (SM1) during the 10-day campaign. No periodic pattern in discharge was seen during the time of observation. The green line is not a fit to the data, but it is included to show what a periodic pattern might appear if the maxima and minima were at 06:00 and 18:00, respectively. The range of values ( 0 to $0.5 \mathrm{~mL} \mathrm{~min}-1)$ was selected to capture the full range of values actually observed in the data. With samples collected every 6 hours, a curve with the resolution similar to that depicted by the green line could not be obtained.

\subsection{Nitrate concentration in collected inseepage}

\subsubsection{0-Day Campaign (June)}

There was no temporal pattern in $\mathrm{NO}_{3}{ }^{-}$concentration in samples recovered every 6 hours from the seepage meters (Figure 17). There were spatial differences in $\mathrm{NO}_{3}{ }^{-}$with concentrations declining generally in the upstream direction, and from left to right when 


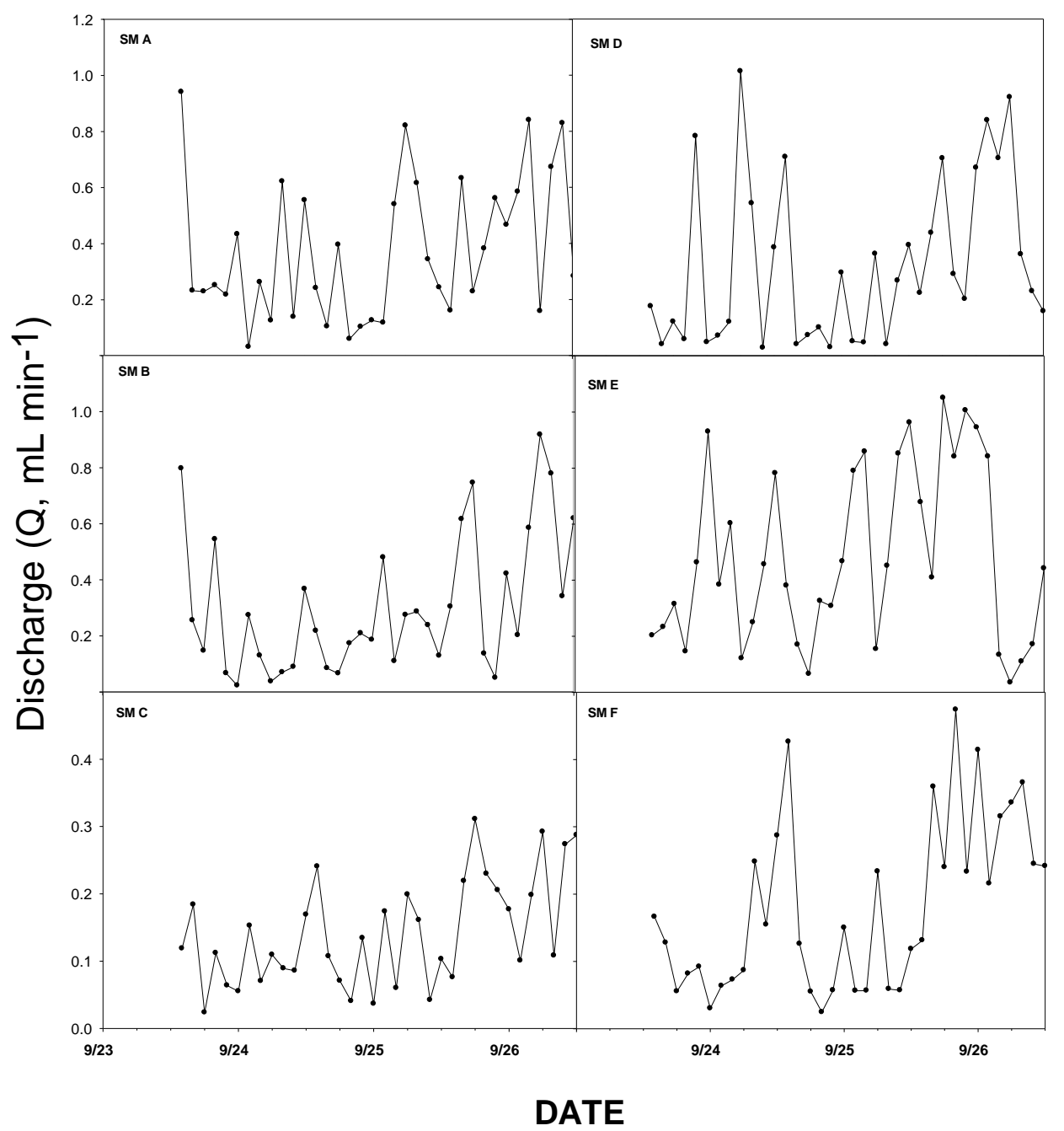

Figure 16. Groundwater discharge into the seepage meters placed in Cobb Mill Creek for 3 days in September, 2010. The arrangement of the plots depicts the general arrangement of the meters throughout the stream reach (see Figure 5). Lines connecting the data points were added to simplify following the seepage values with time. Note that the individual graphs and data are contained in Appendix B1-B6.

facing upstream. Location 1 had the highest $\mathrm{NO}_{3}{ }^{-}$concentration at about $8 \mathrm{mg} \mathrm{NO}_{3}^{-}-\mathrm{N} \mathrm{L}^{-1}$ (due to the several low values reported the average was about 6.75), and location 9 was lowest with an average of around $0.18 \mathrm{mg} \mathrm{NO}_{3}^{-}-\mathrm{N} \mathrm{L}^{-1}$. 


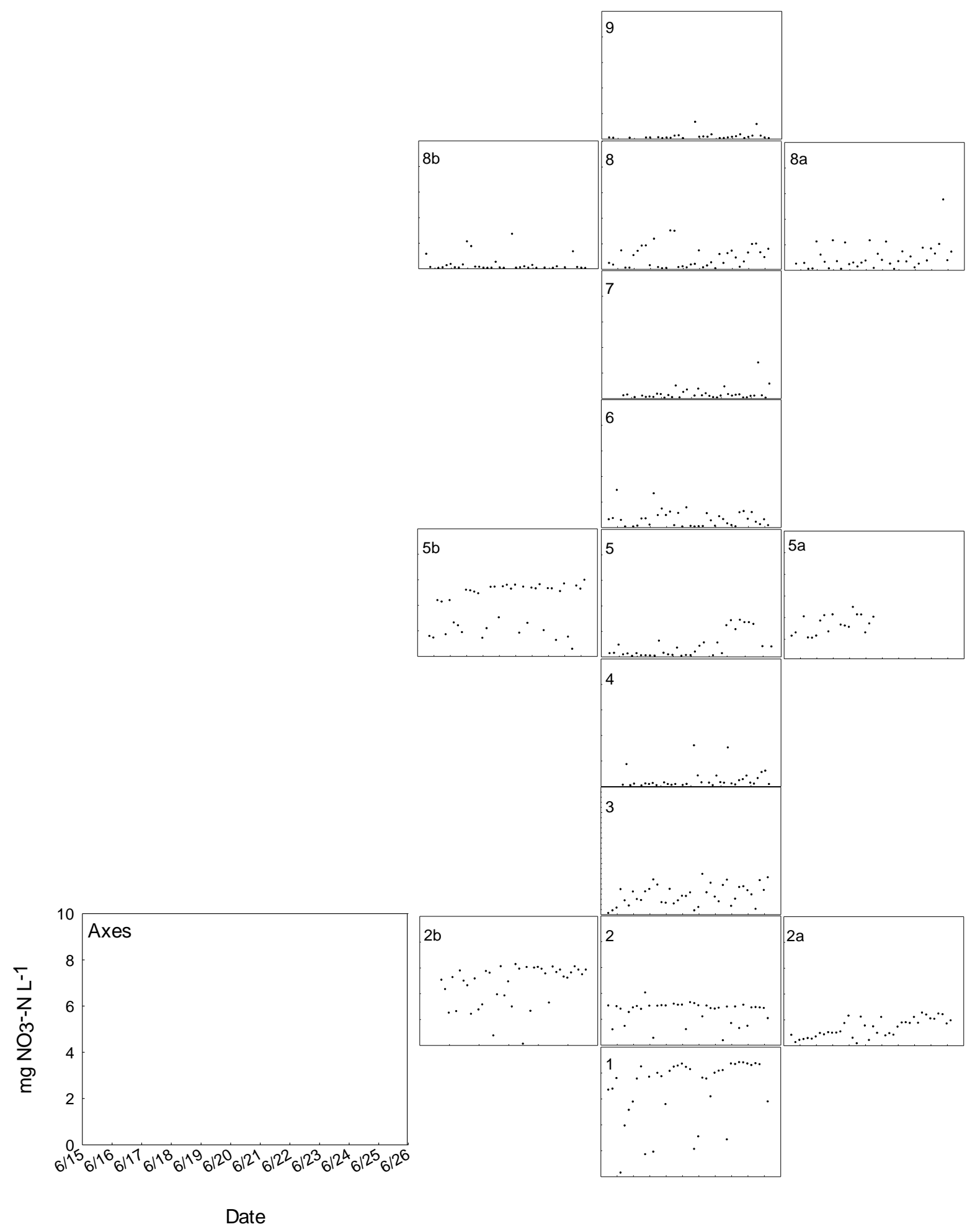

Figure 17. Concentration of $\mathrm{NO}_{3}{ }^{-}$in samples of seepage taken from the various meters deployed in Cobb Mill Creek during the 10-day campaign in June of 2010. The individual graphs are presented in Appendix C. 
Most of the calculated average travel times (i.e., residence times) for groundwater discharging through the biologically active zone into the seepage meters deployed in June were less than one day (Figure 18). Only three of the seepage meters exceeded the 1-day residence time, seepage meters 1 and 5 had a 1-2 day residence time and seepage meter 5a had a 4.8 day residence time. A comparison of the average inseepage residence times and the average nitrate concentration further confirmed that the two parameters were not correlated in this study.

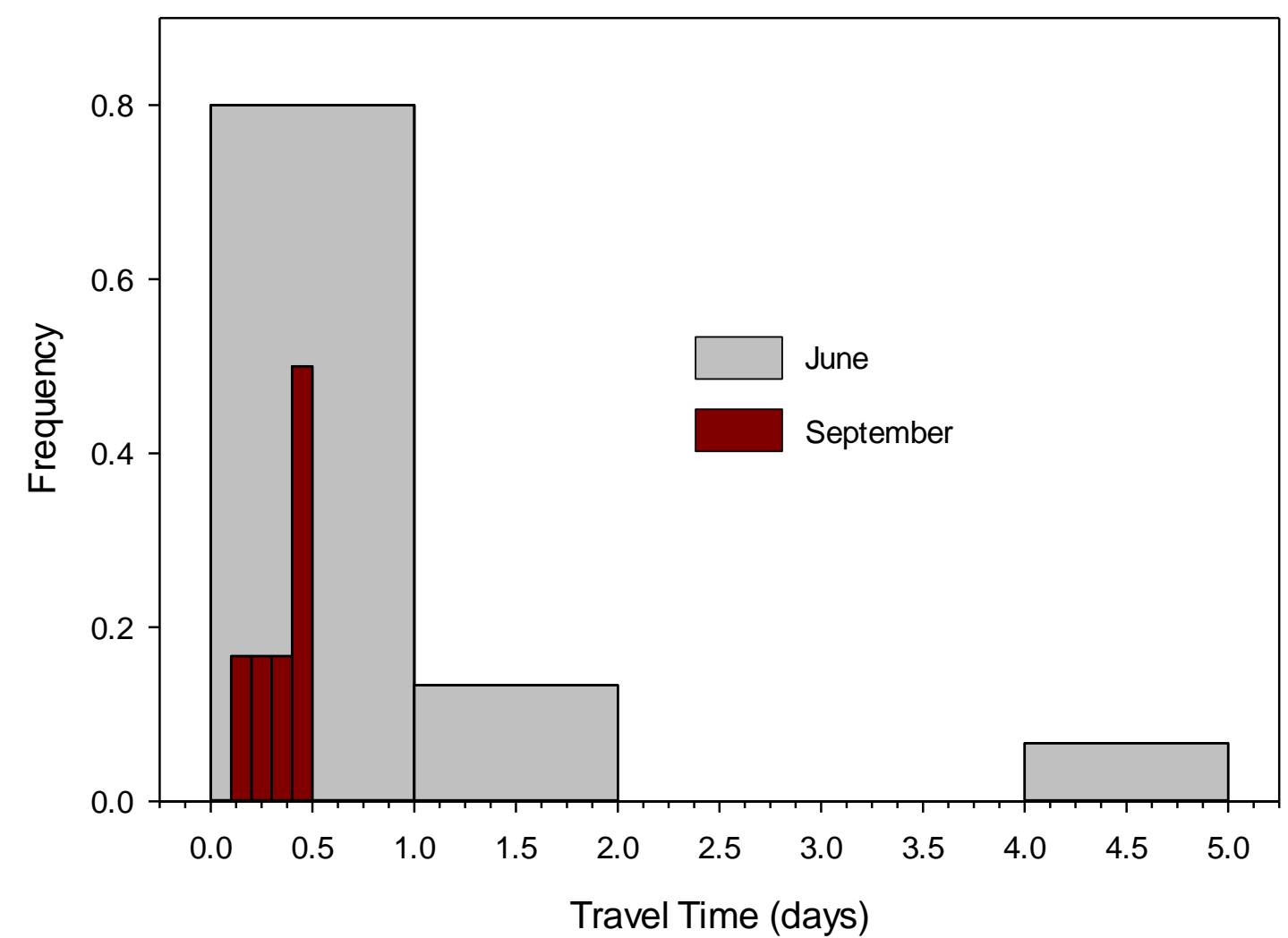

Figure 18. Distribution of travel times computed from seepage-meter data collected in June and September.

\subsubsection{3-Day Campaign (September)}

Similar to the results obtained for inseepage and similar to the June results, there was no observable temporal pattern in $\mathrm{NO}_{3}{ }^{-}$concentrations in the water collected from the seepage 
meters (Figure 19). The average seepage-meter residence times were all less than 0.5 day with the greatest number of meters averaging between 0.4 and 0.5 day residence times (Figure 18). Similar to the case for the June sampling, there was no correlation between the inseepage residence time and nitrate concentration of the water collected from the corresponding seepage meter. The concentration of $\mathrm{NO}_{3}{ }^{-}$did seem to be a bit higher on the left (southwest) side of the stream (facing upstream) than on the opposite side, although significant differences among the mean values (ANOVA) only weakly supported that observation (Table 1).

Table 1: Descriptive statistics for $\mathrm{NO}_{3}{ }^{-}$concentrations in samples from the 6 seepage meters deployed in September. Similar superscript letters associated with the meter identifier indicate no significance difference between that meter and any other with the same letter appended (one-way ANOVA with pairwise comparison using Tukey's test). Median values suggest the data are skewed.

\begin{tabular}{ccrrrrr}
\hline & \multicolumn{7}{c}{ Meter } \\
\hline & $\mathrm{A}^{\mathrm{bc}}$ & $\mathrm{B}^{\mathrm{a}}$ & $\mathrm{C}$ & $\mathrm{D}^{\mathrm{ab}}$ & $\mathrm{E}^{\mathrm{a}}$ & $\mathrm{F}^{\mathrm{c}}$ \\
\hline Mean & 5.36 & 7.36 & 3.36 & 6.40 & 6.74 & 5.14 \\
SEM & 0.19 & 0.23 & 0.12 & 0.22 & 0.33 & 0.24 \\
Median & 5.77 & 7.79 & 3.41 & 6.70 & 7.39 & 5.66 \\
\hline
\end{tabular}

\subsection{Pore Water Samples from the 3-Day (September) Campaign}

An additional set of samples was collected in the September sampling campaign. Pore water samples were obtained with a needle-like probe (Berg and McGlathery, 2001) at 2hour increments and varying depths (Figure 21). The data did not support that the inseepage rate affected $\mathrm{NO}_{3}{ }^{-}$concentration and no diurnal or temporal pattern was seen (Appendix G 7). However, as has been seen before, $\mathrm{NO}_{3}{ }^{-}$concentrations in the samples decreased as the sample-collection depths neared the surface. This supports the thought that $\mathrm{NO}_{3}{ }^{-}$was removed, presumably by denitrification processes taking place as the water traveled through the streambed, prior to release into the stream water. 


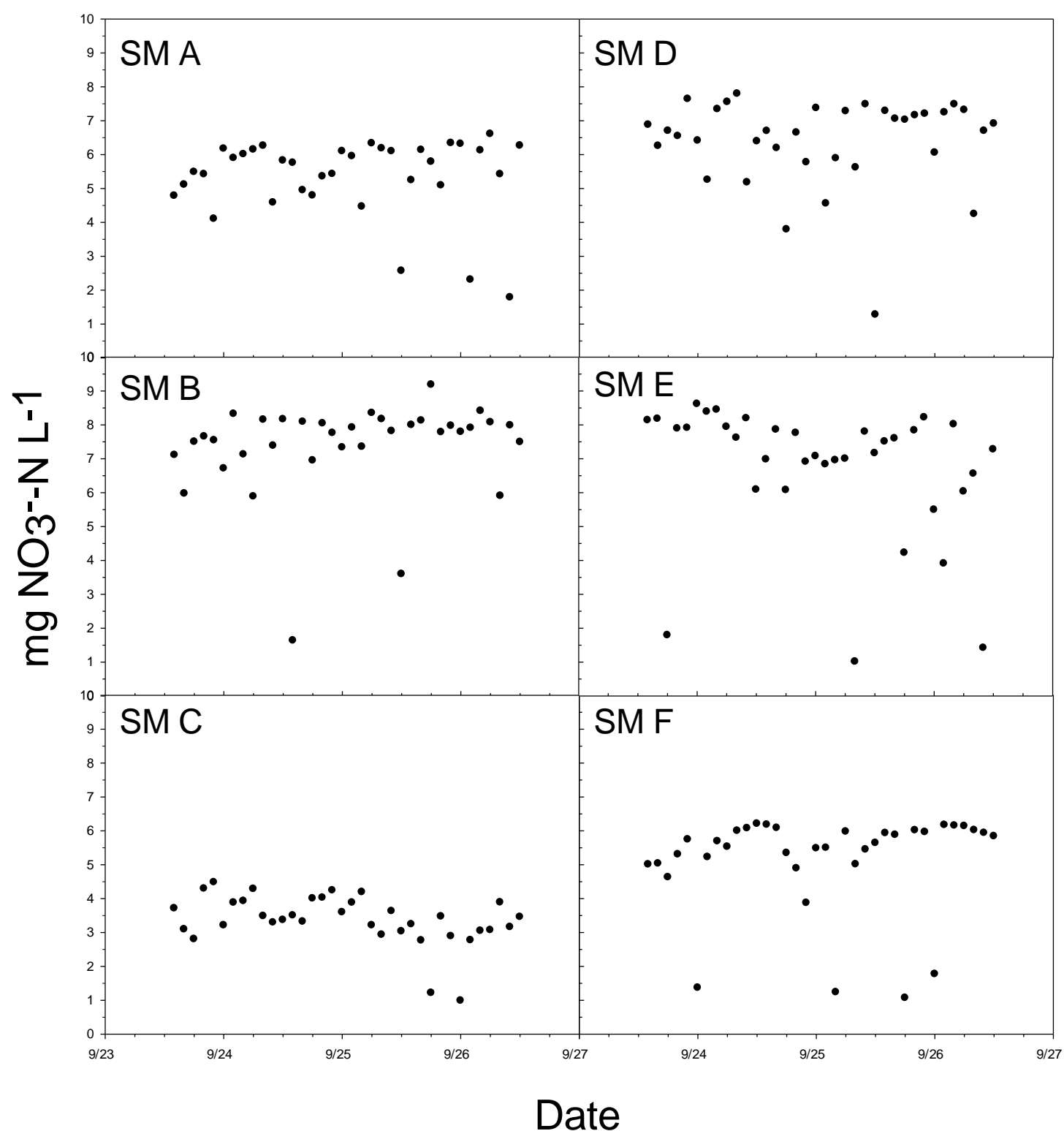

Figure 19. Concentration of $\mathrm{NO}_{3}{ }^{-}$in samples of seepage taken from the various meters deployed in Cobb Mill Creek during the 3-day campaign in September of 2010. 


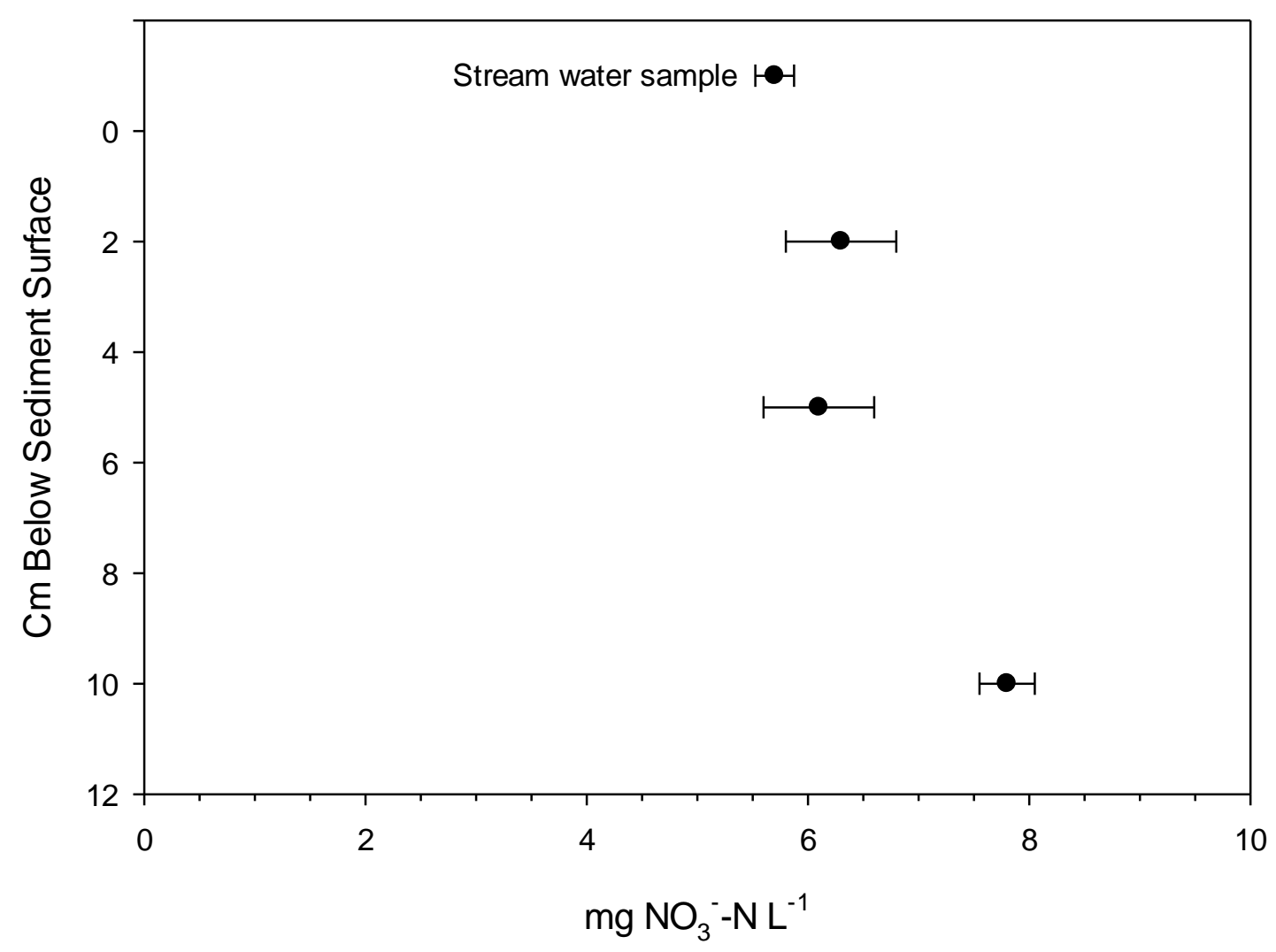

Figure 20. Concentrations of $\mathrm{NO}_{3}{ }^{-}$in porewater samples extracted from Cobb Mill Creek sediments during the September campaign. Nitrate decreased with decreasing depth in the sediment suggesting removal of nitrate as the groundwater discharged toward the surface. The value at $1-\mathrm{cm}$ above the sediment surface represents samples of the stream water collected along with the groundwater samples. Values presented are the mean \pm 1 standard deviation of all 36 samples collected (12/day $\times 3$ days). 


\section{Discussion}

Diurnal variation of both stream stage and nitrate concentration in Cobb Mill Creek was reported by Robertson (2009) and Flewelling et al. (2013). Based on the studies of Gu et al. (2007) and Flewelling et al. (2012) that demonstrated that the $\mathrm{NO}_{3}{ }^{-}$concentrations in the stream and in the discharge from the groundwater were related to the residence time of the groundwater in the biologically active sediment, Flewelling et al. (2013) related evapotranspiration by vegetation proximal to the stream to the diurnal fluctuation of the stream stage, and consequently to the discharge rate of $\mathrm{NO}_{3}{ }^{-}$-rich groundwater. The authors then modeled the fate of $\mathrm{NO}_{3}{ }^{-}$in that same discharging water and showed that the fluctuating discharge rate could play a significant role in controlling $\mathrm{NO}_{3}{ }^{-}$removal in the sediments. They could, therefore, produce diurnal variation in the $\mathrm{NO}_{3}{ }^{-}$concentration of stream water that approximated what was observed during the short period of their investigation. The present report attempted to lengthen the period of observation for that fluctuation in $\mathrm{NO}_{3}{ }^{-}$ concentration in the stream, and also attempted to measure time-dependent changes in both discharge and $\mathrm{NO}_{3}{ }^{-}$concentration in the inseepage from those biologically active sediments.

The ten day study in June, stream-stage data displayed a clear diurnal signal similar to the sinusoidal (diurnal) pattern described in prior studies that examined temporal variability in stream stage (Burt, 1979; Flewelling et al., 2013; Kobayashi et al., 1995; Kobayashi et al., 1990). Spectral analysis yielded a strong signal peak at the 144-samples (24-hour) autocorrelation period that confirmed the diurnal signal of the stream stage. A similar analysis on the 3 days of stage data collected at Cobb Mill Creek during the observational period reported by Robertson (2009) gave the same results as obtained here. 
A similar diurnal signal was found in the $\mathrm{June} \mathrm{NO}_{3}{ }^{-}$data from this study, though there was a lot of noise in the diurnal cycle pattern created by the aberrant samples that contained lower concentrations of $\mathrm{NO}_{3}{ }^{-}$than most. Nitrate data from Robertson (2009) did not exhibit a similar variance of sample $\mathrm{NO}_{3}{ }^{-}$concentrations. No definitive explanation for the outlying $\mathrm{NO}_{3}{ }^{-}$samples can be determined given the data available, however the observation that all "aberrant" concentrations fell below the general pattern in which the expected fluctuation was observed is consistent with the possibility of contamination. This contamination would have to have occurred by the addition of water containing little $\mathrm{NO}_{3}{ }^{-}$between the time of sampling and the analysis for $\mathrm{NO}_{3}{ }^{-}$in the laboratory, though all samples collected were treated to exactly the same processing steps prior to analysis.

In an attempt to clarify possible fluctuations in the water column $\mathrm{NO}_{3}{ }^{-}$concentration, the low-concentration points were "corrected" by re-plotting the points as the average of the point immediately before and the point immediately after the sample point in question. When the correction was done, the diurnal variation in $\mathrm{NO}_{3}{ }^{-}$concentration was much more obvious. The data generally showed an upward trend over the 10 days of observation so that spectral analysis required a detrending (by fitting a quadratic equation to the data, then subtracting the value of the quadratic from the raw data at each individual point) of the data to proceed. After detrending, a spectral analysis could still not be run because of the missing 24-hr of values in the center of the data set. Thus, a limited analysis was done on the portion of the data after the gap. The result (Figure 11) was not clear. Although there was a definite increase in spectral density moving from high frequency to lower frequency, the spectral density did not decrease again at the longer times, including those well outside the range of the study. Although the corrected results for the last 4 days of the study appeared to have a 
periodic signal, the spectral analysis was unable to define that signal clearly from the lower frequencies that were also present.

Robertson (2009) observed that in winter (February), little fluctuation was seen in either stage or $\mathrm{NO}_{3}{ }^{-}$-concentration data. That lack of response was attributed to the fact that the vegetation adjacent to the stream was senescent and therefore evapotranspiration was not as great as would be expected when the trees and shrubs were fully leafed out and actively photosynthesizing. The September effort was conducted then as opposed to later in the fall in order to try and reproduce the conditions seen in June. However, the stream stage was substantially lower and the range in the periodic fluctuation was reduced to less than $1 \mathrm{~cm}$ (Figure 12) as compared with just over $3 \mathrm{~cm}$ in June (Figure 8) suggesting substantially reduced evapotranspiration. The $\mathrm{NO}_{3}{ }^{-}$concentration of the stream samples collected with the ISCO sampler was similarly subdued and lacked any visible diurnal pattern. The reduced stream stage was brought on by the above average temperature and reduced precipitation during the summer months preceding the second sampling campaign. Precipitation for the month preceding the June sampling campaign was $91 \mathrm{~mm}$, while in the month prior to the September campaign, only $18 \mathrm{~mm}$ of precipitation were received. Although the leaves on the trees were still green, it is possible that water stress could have reduced their activity, including transpiration, which would account for the lowered daily fluctuation in stream stage. The reduced evapotranspiration, then would cause a smaller change in discharge of water through the sediment, resulting in a less pronounced diurnal fluctuation in $\mathrm{NO}_{3}{ }^{-}$ removal from the discharging water. Consequently, the concentration of $\mathrm{NO}_{3}{ }^{-}$in the stream was nearly constant over the 24-hr day as compared with June, and as reported by Robertson (2009) and Flewelling et al. (2013). 
The reports by Robertson (2009) and Flewelling et al. (2013) asserted that evapotranspiration, through its influence on travel (residence) times for $\mathrm{NO}_{3}{ }^{-}$-rich water in streambed sediments, would be a major control on $\mathrm{NO}_{3}{ }^{-}$concentration in the stream water. By extension, therefore, both discharge and $\mathrm{NO}_{3}{ }^{-}$concentration should change on a diurnal basis in order to produce the results seen in this, and the earlier studies. When evapotranspiration is minimal, the fluctuation in both stage and $\mathrm{NO}_{3}{ }^{-}$concentration are also minimal. A major motivation for the present study was to extend the earlier findings by observing diurnal changes in the rate of groundwater discharge to the stream and the concentration of $\mathrm{NO}_{3}{ }^{-}$in that inseepage.

To measure and examine the chemistry of the inseepage to the stream, seepage meters (Figure 6) like those that were used in an earlier study (Flewelling et al., 2012) focused on this stream. There are a variety of seepage meter designs that have been used, and some are useful for measuring discharge but are not able to retain sample. The use of meters with condoms is not without criticism, but strong evidence exists for the utility of the condombased meters described by Flewelling et al. (2012) and used here. The original report of seepage meters conceptually similar to those used here was by Lee (1977) who employed ends cut from 55-gallon drums with the inseepage displacing water into large plastic bags ("baggies"). The large diameter of the drums was beneficial to study of groundwater slowly seeping into lakes that were being studied in that report. Shortly thereafter, Lock and John (1978) reported the first use of condoms as a receiver for inseepage. The use of condoms as collection vessels for inseepage has raised concerns among some investigators, and as a result, other designs have been employed for the measurement of discharge from sediments to streams. Brodie et al. (2009) reviewed some of the literature on seepage measurement and 
devised a bag-meter that they asserted addressed issues with meters previously used, such as venturi effects of stream flow on the collection bag, short-term influx anomalies resulting from specific properties of the bags used, accumulation of gas in the chamber that displaces more water than actually seeps through the sediments, and head loss due to frictional resistance. However, Brodie et al. (2009) made no direct comparison of any conventional meter with the design they presented. Neither was there any mention of earlier designs that addressed some of the issues raised by the authors such as accumulation of biogenic gas in the meters (McIntire et al., 1988). A design for a bag-meter for use in rapidly flowing water was presented by Rosenberry (2008), and a bag-less meter that used an electromagnetic sensor for making temporally spaced measurements was offered by Rosenberry and Morin (2004). However, none of these designs are used frequently by other researchers. A number of other authors have expressed concerns over the use of condoms as the collectors on seepage meters. Issues such as deterioration and leaking, resistance to inflow as the condoms reach their "fill capacity" volume held before the latex begins to stretch, taken as about 125 $\mathrm{mL}$ in this study, and changes in water chemistry over time have been raised as points of concern (Harvey and Lee, 2000; Schincariol and McNeil, 2002). In these reports, the concern has always been over condoms left in place for long periods of time. In the present study, the condoms were never in place more than 6 hours, and only rarely did the amount of water collected ever approach the fill capacity.

The question of "relaxation" of the condoms creating an artificial suction that draws water into the reservoir was successfully answered by Koopmans and Berg (2011), who compared meters using several different reservoirs (i.e., different types of plastic bags and condoms) with an ingenious dye-displacement meter. In the latter, no reservoir was used, 
rather the outlet of the meter was connected to a long tube open at the distal end. A small bolus of dye was injected into the tube, and when water entered the meter, the dye was displaced some distance down the tube. Given the uniform cross-sectional area of the tube, the displacement distance reflects the volume of water entering the meter. When the dyedisplacement meter was compared with a condom-based meter, there was a slight negative pressure exerted by the condom, but the magnitude was less than $0.2 \mathrm{~mm}$ of head, and it remained relatively constant until the water in the condom approached the fill volume, at which time the head assumed a large positive value as the latex constituting the condom began to stretch. Given the approximate inseepage rates recorded by prior researchers at this same stream, the use of the 10-cm diameter seepage meter and condom collection system was appropriate.

Earlier studies conducted at approximately the same location along Cobb Mill Creek by (Flewelling et al., 2012; Gu et al., 2007) concluded that groundwater is the primary source of $\mathrm{N}$ in the stream and therefore the groundwater $\mathrm{NO}_{3}{ }^{-}$drives the $\mathrm{NO}_{3}{ }^{-}$concentration of the stream water. Other studies at the same location (Galavotti, 2004; Mills et al., 2008), concluded that there was high denitrification potential in the riparian zone and within the streambed sediment. It was again confirmed that groundwater was directly tied to stream water $\mathrm{NO}_{3}{ }^{-}$concentration. It was these studies and others that primarily lead to the research questions posed in this study. All of the aforementioned reports inferred conclusions about the inseepage from the sediments, but never examined inseepage directly. Some preliminary results from Herman (unpublished) suggested that changes in the inseepage could be followed over time with condom meters. Thus, the primary objective of the present study was to provide that missing definitive connection. 
Samples from the June campaign were collected at 6-hour increments, and neither a single meter nor the aggregate of meters at all locations demonstrated any diurnal signal. Initial evaluation of the data led to the inference that the absence of any pattern might be due to the inability of the 6-hr sample collection intervals to detect pattern in a noisy signal, especially if the sampling times chosen were not able to capture maxima or minima in either the inseepage or $\mathrm{NO}_{3}{ }^{-}$concentration. Other studies (Gribovszki et al., 2008; Robertson, 2009) noted differences in the time of occurrence of stage maxima and minima from what might be expected based on time of dawn and dusk. A literature review of recorded summer diurnal variation for inseepage and stream discharge found that dawn and dusk rarely represented the minima and maxima of recorded diurnal variations. Numerous studies at continental and international locations, such as Virginia (Robertson, 2009), California (Loheide et al., 2005), Pennsylvania (Reigner, 1966), Slovenia (Rusjan and Mikos, 2010), and England (Burt, 1979), summarized in Table 2, have recorded maxima from 10am to $1 \mathrm{pm}$. However, streams located in Hungary (Kalicz et al., 2005) and Northern Japan (Koba Yashi et al., 1990) recorded peak times as early as midnight and as late as $7 \mathrm{pm}$. At Cobb Mill Creek, the daily maximum for both the June and September stream inseepage occurred around 8 am, and it was around 4 am for stream water $\mathrm{NO}_{3}{ }^{-}$concentration (Figure 20).

As asserted by Flewelling et al. (2013), transpiration by vegetation proximal to the stream induces the fluctuations seen by Robertson (2009). If one assumes that transpiration stops around sunset (or upon total darkness), then the water table should rise through the night such that the maximum head gradient might be expected sometime around dawn and the resumption of transpiration. Similarly, one might expect the minimum head gradient to occur right around dusk. Thus, it was thought that sampling around dawn (06:00), mid-day 
(12:00), around dusk (18:00), and midnight (0:00) might capture the widest variations in seepage discharges. Further, if the maximum discharge occurs around dawn, then the rate of $\mathrm{NO}_{3}{ }^{-}$flux to the stream should also be at a maximum then, or shortly thereafter. A similar argument could be made for the discharge and $\mathrm{NO}_{3}{ }^{-}$minima as well.

Table 2: Literature reports of the timing of diurnal maximum values for several variables associated with groundwater stream water interactions.

\begin{tabular}{lllll}
\hline \multicolumn{1}{c}{ Type } & Season/Month & Peak Time & Location & Reference \\
\hline Stream Stage & June & $10: 00-13: 00$ & Cobb Mill Creek & (Robertson, 2009) \\
Stream Nitrate & June & $3: 00-6: 00$ & Cobb Mill Creek & (Robertson, 2009) \\
Stream Nitrate & August & $13: 00-15: 00$ & Cobb Mill Creek & (Robertson, 2009) \\
Groundwater & ?arch & $10: 00$ & California & (Loheide et al., 2005) \\
Inseepage & $12: 00$ & Slovenia & (Rusjan and Mikos, 2010) \\
Inseepage & April & $12: 00$ & Slovenia & (Rusjan and Mikos, 2010) \\
Inseepage & March & $11: 00$ & Slovenia & (Rusjan and Mikos, 2010) \\
Inseepage & April & $11: 00$ & Slovenia & (Rusjan and Mikos, 2010) \\
Inseepage & June & $10: 00$ & Slovenia & (Rusjan and Mikos, 2010) \\
Inseepage & July & $10: 00$ & Slovenia & (Rusjan and Mikos, 2010) \\
Inseepage & October & $9: 00$ & Slovenia & (Rusjan and Mikos, 2010) \\
Inseepage & November & $9: 00$ & Slovenia & (Rusjan and Mikos, 2010) \\
Stream Discharge & Summer & $15: 00$ & Hungary & (Gribovszki et al., 2008) \\
Stream Discharge & Summer & $12: 00-17: 00$ & Hungary & (Kalicz et al., 2005) \\
Stream Discharge & Summer & $16: 00-19: 00$ & Northern Japan & (Koba Yashi et al., 1990) \\
Stream Discharge & Summer & $10: 00-13: 00$ & Somerset, UK & (Burt, 1979) \\
Stream Discharge & Summer & $10: 00-12: 00$ & Pennsylvania & (Reigner, 1966) \\
Stream Stage & Jun, 2010 & $\mathbf{8 : 0 0}$ & Cobb Mill Creek & This Study \\
Stream Nitrate & Jun, 2010 & $\mathbf{4 : 0 0}$ & Cobb Mill Creek & This Study \\
Stream Stage & Sep, 2010 & $\mathbf{8 : 0 0}$ & Cobb Mill Creek & This Study \\
\hline
\end{tabular}

Indeed, fluctuations in stage observed by Robertson (2009) and by Gribovszki et al. (2008) contained a delay in the peak stage of about $1.5 \mathrm{hr}$ from the expected maxima and minima reported above. Under the assumption that the 6-hr sampling interval used in the June study missed the maximum and minimum for each day, and that noise in the signal 

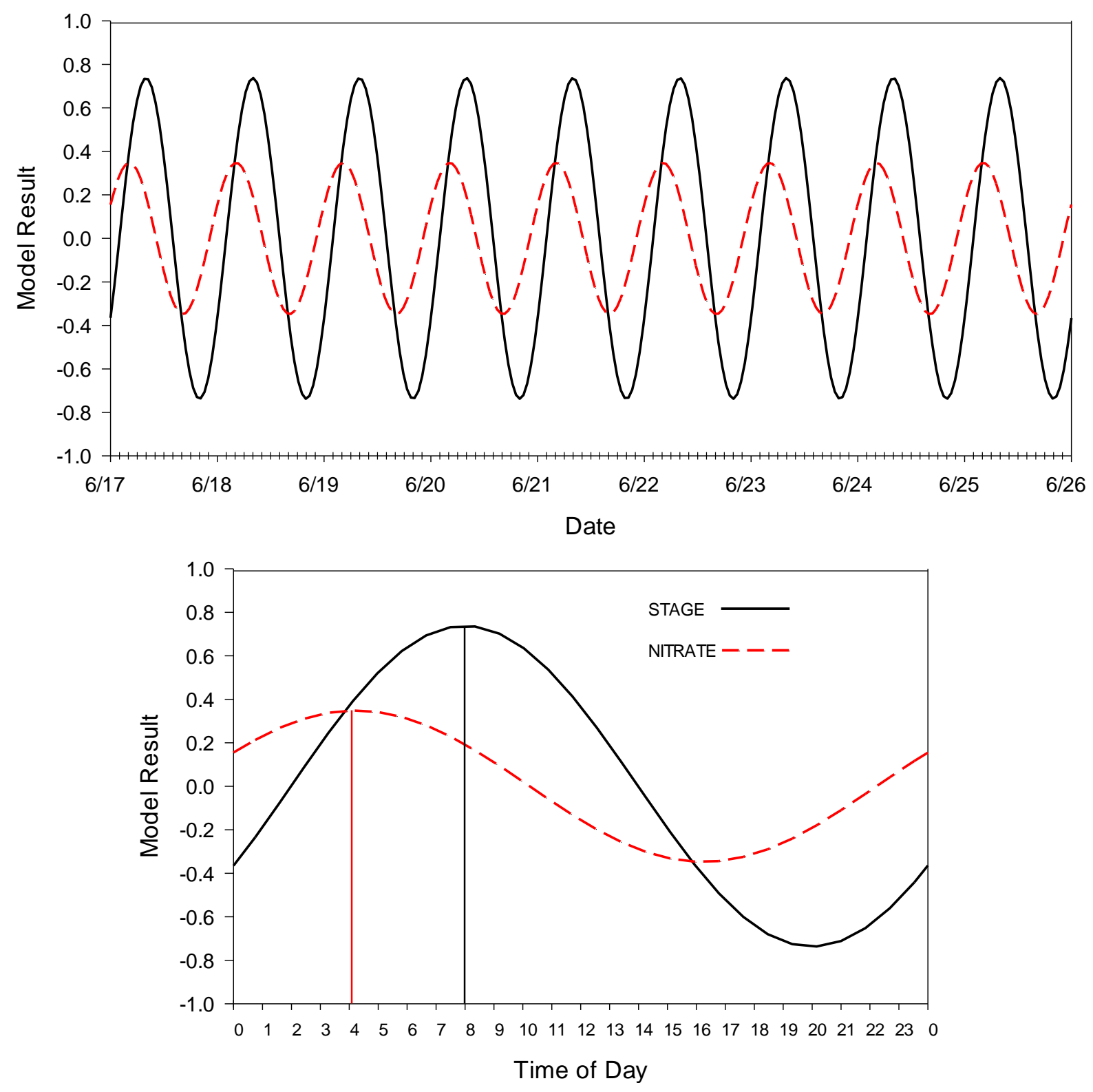

Figure 21. Fit of a sine function to stream stage (black) and streamwater $\mathrm{NO}_{3}{ }^{-}$ concentration in Cobb Mill Creek for a 24-hr period on June 24 to 25. One day of a longer set is plotted here to provide a detailed view of the timing of the daily maximum and minimum for each of the measured variables.

for seepage and $\mathrm{NO}_{3}{ }^{-}$resulted in an undecipherable response pattern, the September campaign was undertaken, and this employed a 2-hr sampling interval. Unfortunately, no discernible pattern in seepage volume or in $\mathrm{NO}_{3}{ }^{-}$concentration could be recovered during 
that effort either. It may be that the smaller changes in stage and stream $\mathrm{NO}_{3}{ }^{-}$concentration observed in September as compared with June obscured the observations made on seepage, i.e., the signal may have decreased with no concomitant change in the noise.

The modelling exercise and the column experiments carried out by Gu et al. (2007) indicated a strong link between groundwater discharge and nitrate concentration in the water exiting the sediment, with high discharges being associated with higher $\mathrm{NO}_{3}{ }^{-}$concentrations due to a reduced residence time for removal of $\mathrm{NO}_{3}^{-}$by denitrification. The observations by Flewelling et al. (2012) tended to confirm that supposition in that areas of Cobb Mill Creek sediment that expressed the highest inseepage rates were also those that produced the highest $\mathrm{NO}_{3}{ }^{-}$concentrations in the discharging seepage. Comparisons of the inseepage rates with the concentrations of $\mathrm{NO}_{3}{ }^{-}$in the inseepage did not show any strong relationship between the two variables in either the June (Figure 22) or the September (Figure 23) sampling times. In a few of the cases (e.g., meters D and F in September) there was a positive relationship at low discharge values (Figure 23), but in other cases the $\mathrm{NO}_{3}^{-}$concentration was relatively constant over the entire range of discharge values, or the $\mathrm{C} v s$. Q relationship appeared to be largely random.

It cannot be said that diurnal changes in seepage volume and $\mathrm{NO}_{3}{ }^{-}$concentration do not occur in the Cobb Mill Creek study site or at similar sites along the eastern shore given different seasonal environmental conditions, but neither was it possible to detect them directly using the approaches employed here. The theoretical evidence and the modeling efforts of Flewelling et al. (2013) indicate that a diurnal fluctuation in discharge and $\mathrm{NO}_{3}{ }^{-}$is to be expected, and it is somewhat surprising that no such diurnal cycling could be detected in either variable measured. 


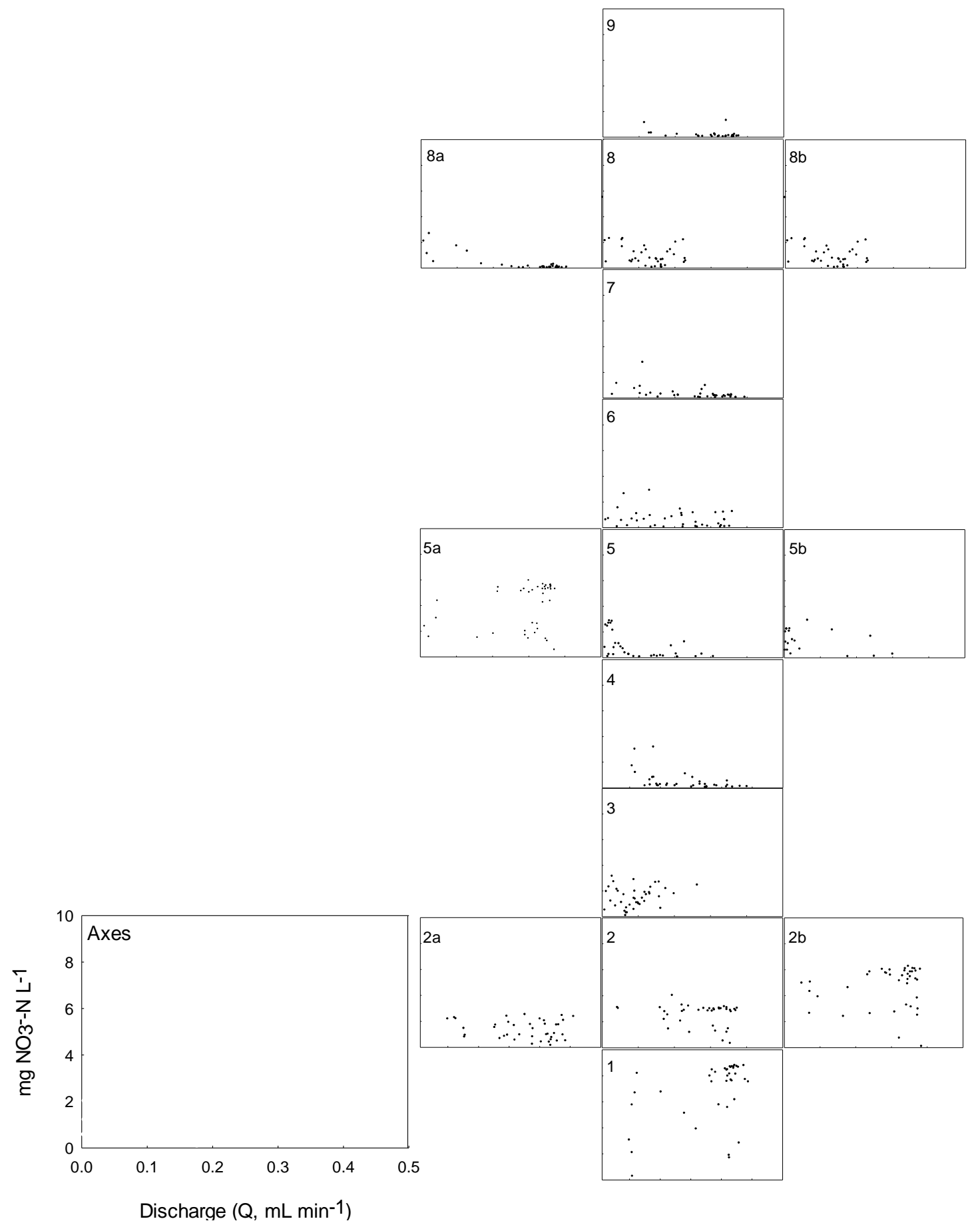

Figure 22. $\mathrm{NO}_{3}{ }^{-}$concentration plotted against discharge (C vs. Q) in seepage meters deployed in Cobb Mill Creek in June of 2010. 


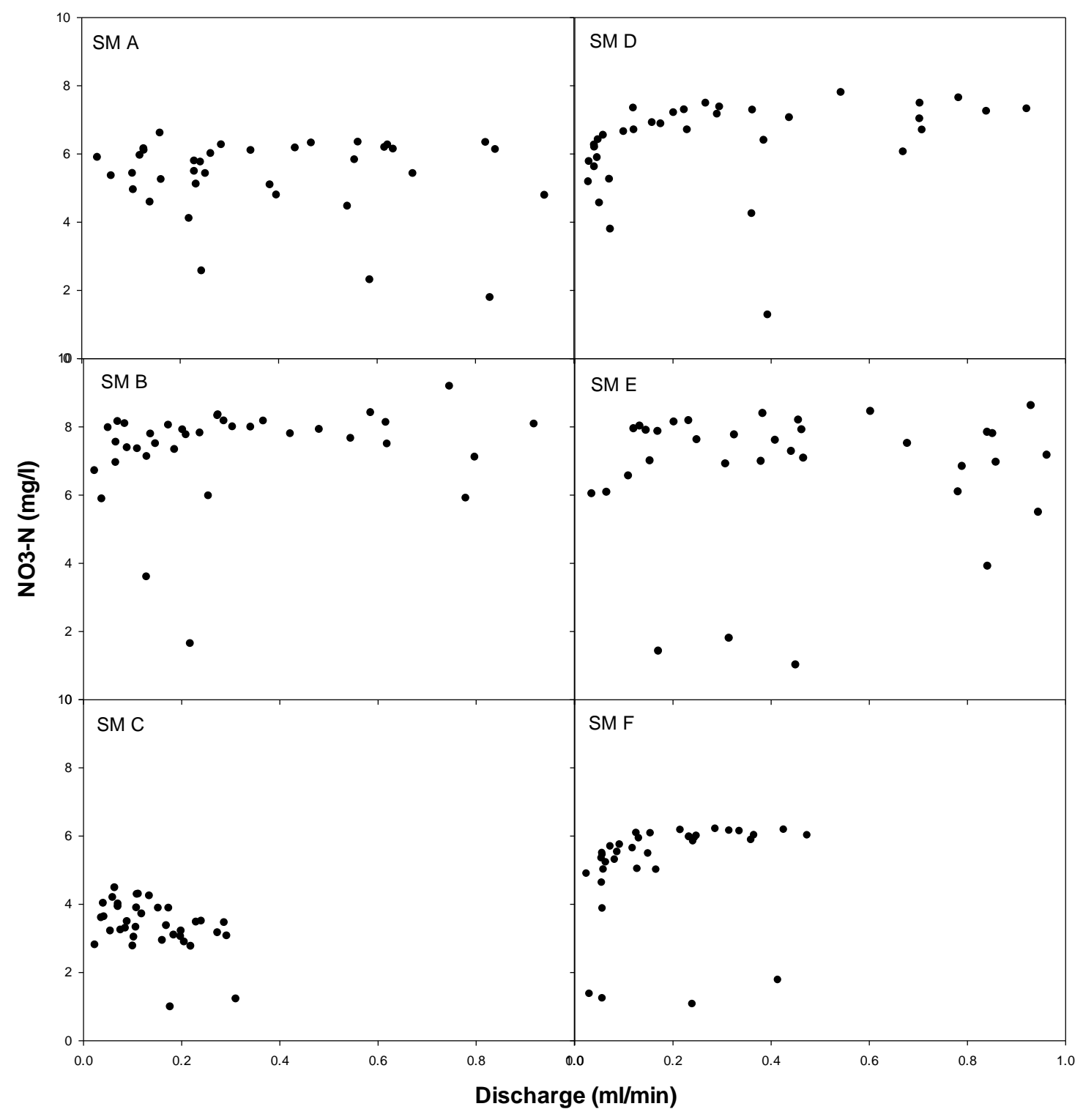

Figure 23. $\mathrm{NO}_{3}{ }^{-}$concentration plotted against discharge (C vs. Q) in seepage meters deployed in Cobb Mill Creek in September of 2010. A composite figure of C vs. Q for all the meters is presented as Appendix F7.

To determine conclusively if diurnal patterns of inseepage and $\mathrm{NO}_{3}{ }^{-}$concentration ever occur, further studies could utilize larger diameter seepage meters that would assist in dampening effects from the spatial heterogeneity in seepage discharge by averaging over a 
larger area. Use of a larger sample area would result in a shorter sample time that might help resolve a temporal signal. Perhaps a first step would be to use a continuously recording meter such as the electromagnetic meter suggested by Rosenberry and Morin (2004). Such a meter would not allow collection of samples for $\mathrm{NO}_{3}{ }^{-}$analysis, however.

Another approach to examining diurnal fluctuation in seepage would be the use of a manometer like the one reported by Kennedy et al. (2007) and used by McFadden (2013) in several Eastern Shore stream. The device could be modified to provide a continuous measure of head gradient at a set depth, and assuming no change in hydraulic conductivity, the discharge could be inferred from Darcy's equation.

Use of a larger diameter condom-based meter would need to be studied with respect to the residence time of seepage water within the chamber before displacement into the condom. In the most extreme case, use of a 55-gallon drum and a condom that would hold $125 \mathrm{~mL}$ of water, the drum would hold just over 21 condom volumes of water per $\mathrm{cm}$ of the drum that sat above the sediment surface (assumes a drum diameter of 23 inches [58 $\mathrm{cm}$ ] http://www.erosionpollution.com/55-gallon-drum-dimensions.html). It would be hard to determine the timing of $\mathrm{NO}_{3}{ }^{-}$concentration changes with such a long retention time in the drum, and that problem could be amplified by substantial additional denitrification that could occur during the water residence time inside the drum.

Another approach might be to install an array of needle samplers like those of Berg and McGlathery (2001) into the sediment at one or more depths and then drawing small samples for ion analysis at appropriate time intervals. From such data, the concentration in the water exiting the sediments could be inferred and changes over time determined.

Although the data are often noisy and do not show diurnal fluctuations, when each 
sampling location is viewed as a unit and compared with the others, spatial differences are quite apparent, and are roughly consistent with the single-time measurements made by Flewelling et. al. (2012). The allocation of samplers used in this study recognized the importance of spatial variability and should be a component of any future inseepage- $\mathrm{NO}_{3}{ }^{-}$ samplings, even if larger meters are employed in order to fully understand the effects and variability that evapotranspiration could have on each sample site in the streambed over time.

Variability in the $\mathrm{NO}_{3}{ }^{-}$concentration of the water column versus the inseepage could also be attributed to the fact that water flowing overland or horizontally into the stream channel could have a diluting (or concentrating) effect on $\mathrm{NO}_{3}{ }^{-}$in the stream. Additionally, Flewelling et al. (2012) found that the increased influx of water to Cobb Mill Creek during and immediately after a storm is a mix of water entering from the streambed, as well as from other contributing sources including shallow groundwater stored in the hillslope banks proximal to the stream. Flewelling et al. (2012) observed that the chloride concentration in the stream water went up during and after storm events, while the $\mathrm{NO}_{3}{ }^{-}$concentration dropped. It was concluded that the changes in $\mathrm{NO}_{3}{ }^{-}$and chloride concentrations were due to discharge from overland or horizontal flow entering the stream channel. This could have been the case for the stream water collected during the June campaign, which could have been more of a mix of side and streambed inseepage, while September would have been predominately streambed, due to local climatic conditions at the time of the sampling campaigns.

Despite careful and well planned work, and even though diurnal fluctuations in stage and $\mathrm{NO}_{3}{ }^{-}$concentrations in stream water were seen, periodic fluctuations in seepage discharge and $\mathrm{NO}_{3}{ }^{-}$concentrations in that discharge could not be detected. Fluctuations in both 
variables were present, but no periodicity, or coherence of any sort, could be detected. Observations of water-column properties suggest that some periodic fluctuation in the groundwater $\mathrm{NO}_{3}{ }^{-}$flux must be present. Other factors, such as water column processes that act on $\mathrm{NO}_{3}{ }^{-}$(e.g., photosynthesis), could help explain the observed periodicity in the surface water, but photosynthesis cannot explain the fluctuation in stream stage. Consensus in the literature with respect to evapotranspiration as the driver of diurnal fluctuation of stream stage is consistent with findings in this study and in Robertson's work ((Flewelling et al., 2013; Robertson, 2009). Additional work could easily make use of larger seepage meters or other devices for obtaining discharge and $\mathrm{NO}_{3}{ }^{-}$flux values in order to demonstrate conclusively the behavior of seepage and $\mathrm{NO}_{3}{ }^{-}$with respect to evapotranspiration in these small, but ecologically important streams. 


\section{Literature Cited}

Berg P, McGlathery K. 2001. A high-resolution pore water sampler for sandy sediments. Limnology \& Oceanography, 46(1): 203-210.

Blum LK, Mills AL. 2012. Estuarine Microbial Ecology. In Estuarine Ecology. J.W. Day, Jr, W.M. Kemp, A. Yáñez-Arancibia and B.C. Crump (Editors). Wiley-Blackwell, pp. 235-262.

Boesch DF, Brinsfield RB, Magnien RE. 2001. Chesapeake Bay eutrophication: scientific understanding, ecosystem restoration, and challenges for agriculture. Journal of Environmental Quality, 30: 303-320.

Box GEP, Jenkins GM, Reinsel GC. 1994. Time series analysis: forcasting and control. Prentice Hall, Englewood Cliffs, NJ, 598.

Brodie RS, Baskaran S, Ransley T, Spring J. 2009. Seepage meter: progressing a simple method of directly measuring water flow between surface water and groundwater systems. Australian Journal of Earth Sciences, 56(1): 3-11. 10.1080/08120090802541879.

Burt TP. 1979. Diurnal variations in stream discharge and throughflow during a period of low flow. Journal of Hydrology, 41: 11.

Canter LW. 1997. Nitrates in Groundwater. CRC Press, Inc., Boca Raton, FL, 263.

Denver JM, Ator SW, Debrewer LM, Ferrari MJ, Barbaro JR, Hancock TC, Brayton MJ, Nardi MR. 2003. Water Quality in the Delmarva Peninsula: Delaware, Maryland, and Virginia, 1999-2001. 1228, USGS, Reston, VA.

Dodds WK, Bouska WW, Eitzmann JL, Pilger TJ, Pitts KL, Riley AJ, Schloesser JT, Thornbrugh D. 2009. Eutrophication of U.S. freshwaters: analysis of potential economic damages. Environmental Science \& Technology, 43(1): 12-19.

Flewelling SA. 2009. Nitrogen storage and removal in catchments on the Eastern Shore of Virginia. Ph.D. Dissertation, University of Virginia, Charlottesville, VA.

Flewelling SA, Hornberger GM, Herman JS, Mills AL. 2012. Travel time controls the magnitude of nitrate discharge in groundwater bypassing the riparian zone to a stream on virginia's coastal plain. Hydrological Processes, 26: 1242-1253. DOI: 10.1002/hyp.8219.

Flewelling SA, Hornberger GM, Herman JS, Mills AL, Robertson WM. 2013. Diel patterns in coastal-stream nitrate concentrations linked to evapotranspiration in the riparian zone of a low-relief, agricultural catchment. Hydrological Processes. 10.1002/hyp.9763.

Galavotti H. 2004. Spatial profiles of sediment denitrification at the ground water-surface water interface in Cobb Mill Creek on the Eastern Shore of Virginia MS, University of Virginia, Charlottesville.

Gold AJ, Groffman PM, Addy K, Kellogg DQ, Stolt M, Rosenblatt AE. 2001. Landscape attributes as controls on ground water nitrate removal capacity of riparian zones. Journal of the American Water Resources Association, 37(6): 1457-1464.

Gribovszki Z, Kalicz P, Szilagyi J, Kucsara M. 2008. Riparian zone evapotranspiration estimation from diurnal groundwater level fluctuations. Journal of Hydrology, 349(12): 6-17. 10.1016/j.jhydrol.2007.10.049. 
Gu C. 2007. Hydrological control on nitrate delivery through the groundwater surface water interface. Ph.D., University of Virginia, Charlottesville, $250 \mathrm{pp}$.

Gu C, Hornberger GM, Mills AL, Herman JS. 2008a. The effect of freshets on the flux of groundwater nitrate through streambed sediments. Water Resources Research, doi:10.1029/2007WR006488.

Gu C, Hornberger GM, Mills AL, Herman JS. 2008b. Influence of stream-aquifer interactions in the riparian zone on nitrate flux to a low-relief coastal stream. Water Resources Research, 44(W44132). 10.1029/2007WR006739.

Gu C, Hornberger GM, Mills AL, Herman JS, Flewelling SA. 2007. Nitrate reduction in streambed sediments: effects of flow and biogeochemical kinetics. Water Resources Research, 43: W12413, doi:10.1029/2007WR006027.

Harvey FE, Lee DL. 2000. Discussion on 'The effects of bag type and meter size on seepage meter measurements' by SA Isiorho and JH Meyer, May-June 1999 issue, v 37, no 3: 411-413. GroundWater, 38: 326-327.

Heinberg R, Bomford M. 2009. The food and farming transition: toward a post-carbon food system.

Hill AR. 1990. Ground-water flow paths in relation to nitrogen chemistry in the near-stream zone. Hydrobiologia, 206(1): 39-52.

International Energy Agency. 2008. World Energy Outlook, 2008. International Energy Agency, Paris, France.

Kalicz P, Gribovszki Z, Kucsara M, Vig P. 2005. A vegetáció hatása egy kisvízgyjtó patakjának alapvízhozam mintázatára (Vegetation influence on base flow characteristics of upper watersheds' streams). Hidrológiai Közlöny, 85(6): 50-52 (in Hungarian).

Kennedy CD, Genereux DP, Corbett DR, Mitasova H. 2007. Design of a light-oil piezomanometer for measurement of hydraulic head differences and collection of groundwater samples. Water Resources Research, 43(9). W09501 10.1029/2007wr005904.

Kennedy CD, Genereux DP, Corbett DR, Mitasova H. 2009a. Relationships among groundwater age, denitrification, and the coupled groundwater and nitrogen fluxes through a streambed. Water Resources Research, 45. W09402 10.1029/2008wr007400.

Kennedy CD, Genereux DP, Corbett DR, Mitasova H. 2009b. Spatial and temporal dynamics of coupled groundwater and nitrogen fluxes through a streambed in an agricultural watershed. Water Resources Research, 45. W09401 10.1029/2008wr007397.

Knobeloch L, Salna B, Hogan A, Postle J, Anderson H. 2000. Blue Babies and NitrateContaminated Well Water. Environmental Health Perspectives, 108: 675-678.

Koba Yashi D, Suzuki K, Nomura M. 1990. Diurnal fluctuation in stream flow and in specific electric conductance during drought periods. Journal of Hydrology, 115(14): 105-114. http://dx.doi.org/10.1016/0022-1694(90)90200-H.

Kobayashi D, Kodama Y, Ishii Y, Tanaka Y, Suzuki K. 1995. Diurnal variations in streamflow and water quality during the summer dry season. Hydrological Processes, 9: 8 .

Kobayashi D, Suzuki K, Nomura M. 1990. Diurnal fluctuation in stream flow and in specific electric conductance during drought periods. Journal of Hydrology, 115: 10. 
Koopmans DJ, Berg P. 2011. An alternative to traditional seepage meters: Dye displacement. Water Resources Research, 47(1): W01506. 10.1029/2010WR009113.

Korom SF. 1992. Natural denitrification in the saturated zone: a review. Water Resources Research, 28: 1657-1668.

Lee DH. 1977. A device for measuring seepage flux in lakes and estuaries. Limnology and Oceanography, 22(1): 140-147.

Lock MA, John PH. 1978. Measurement of Groundwater Discharge into a Lake by a Direct Method. Internationale Revue Der Gesamten Hydrobiologie, 63(2): 271-275. 10.1002/iroh.19780630212.

Loheide S, Butler J, Gorelick S. 2005. Estimation of groundwater consumption by phreatophytes using diurnal water table fluctuations: A saturated-unsaturated flow assessment. Water Resources Research, 41: doi:10.1029/2005WR003942.

Lowrance R. 1998. Riparian forest ecosystems as filters for nonpoint-source pollution. In Successes, limitations, and frontiers in ecosystems science. M.L. Pace and P.M. Groffman (Editors). Springer, pp. 113-141.

Lowrance R, Altier LS, Newbold JD, Schnabel RR, Groffman PM, Denver JM, Correll DL, Gilliam JW, Robinson JL, Brinsfield RB, Staver KW, Lucas W, Todd AH. 1997. Water quality functions of riparian forest buffers in Chesapeake Bay watersheds. Environmental Management, 21(5): 687-712.

Lowrance R, Hubbard RK, Williams RG. 2000. Effects of a managed three zone riparian buffer system on shallow groundwater quality in the southeastern Coastal Plain. Journal of Soil and Water Conservation, 55(2): 212-220.

Lowrance R, Todd R, Fail J, Hendrickson O, Leonard R, Asmussen L. 1984. Riparian forests as nutrient filters in agricultural watersheds. BioScience, 34(6): 374-377.

Maag M, Malinovsky M, Nielsen SM. 1997. Kinetics and temperature dependence of potential denitrification in riparian soils. Journal of Environmental Quality, 26(1): 215-223.

McCarty GW, Angier J, Rice CP, Bialek K. 2008. Impact of temporal and spatial variations in agrochemical fluxes within the riparian buffer on exports from a first order watershed, AWRA Specialty Conference on Riparian Processes. American Water Resources Association, Norfolk, VA.

McFadden GS. 2013. Streambed sediments of Virginia Eastern Shore streams are poised for pore-water denitrification, University of Virginia, Charlottesville, VA, $100 \mathrm{pp}$.

McIntire PE, Mills AL, Hornberger GM. 1988. Groundwater lake interactions and the occurrence of high sulfate concentrations at depth in the sediment of Lake Anna, Virginia. Hydrological Processes, 2: 207-217.

Mills AL, Herman JS, Anutaliya A. 2011. Sediments as filters of applied nitrogen from discharging groundwater to low-relief coastal streams, Coastal and Estuarine Research Federation, Daytona Beach, FL.

Mills AL, Hornberger GM, Herman JS. 2008. Sediments in low-relief coastal streams as effective filters of agricultural nitrate, AWRA Specialty Conference on Riparian Processes. American Water Resources Association, Norfolk, VA.

Montgomery HAC, Dymock JF. 1961. The determination of nitrite in water. Analyst, 86: 414-416. 
Nelson WM, Gold AJ, Groffman PM. 1995. Spatial and temporal variation in groundwater nitrate removal in a riparian forest. Journal of Environmental Quality, 24(4): 691699.

Norton MM, Fisher TR. 2000. The effects of forest on stream water quality in two coastal plain watersheds of the Chesapeake Bay. Ecological Engineering, 14: 337-362.

Ocampo CJ, Sivapalan M, Oldham C. 2006. Hydrological connectivity of upland-riparian zones in agricultural catchments: Implications for runoff generation and nitrate transport. Journal of Hydrology, 331(3-4): 643-658. 10.1016/j.jhydrol.2006.06.010.

Pavel EW, Reneau Jr. RB, Berry DF, Smith EP, Mostaghimi S. 1996. Denitrification potential of nontidal riparian wetland soils in the Virginia coastal plain. Water Research, 30(11): 2798-2804.

Pinay G, Roques L, Fabre A. 1993. Spatial and Temporal Patterns of Denirification in a Riparian Forest. The Journal of Applied Ecology, 30(4): 11.

Rabalais NN, Turner RE, Wiseman WJ. 2001. Hypoxia in the Gulf of Mexico. Journal of Environmental Quality, 30(2): 320-329.

Ranalli AJ, Macalady DL. 2010. The importance of the riparian zone and in-stream processes in nitrate attenuation in undisturbed and agricultural watershed - A review of the scientific literature. Journal of Hydrology, 389: 406-415. 10.1016/j.jhydrol.2010.05.045.

Reigner IC. 1966. A method of estimating streamflow loss by evapotranspiration from riparian zone. Forest Science, 12: 130-139.

Ritter AF, K. W, Lonhart SI, Preisler RK, Woolfolk A, Griffith KA, Connors S, Heiman K. 2008. Ecological signatures of anthropogenically altered tidal exchange in estuarine ecosystems. Estuaries and Coasts, 31(3): 554-571.

Robertson WM. 2009. Diurnal Variations in Nitrate Concentrations in the Cobb Mill Creek, $V A$, University of Virginia, Charlottesville, VA, $122 \mathrm{pp}$.

Rosenberry DO. 2008. A seepage meter designed for use in flowing water. Journal of Hydrology, 359(1-2): 118-130. http://dx.doi.org/10.1016/j.jhydrol.2008.06.029.

Rosenberry DO, Morin RH. 2004. Use of an electromagnetic seepage meter to investigate temporal variability in lake seepage. Ground Water, 42(1): 68-77. 10.1111/j.17456584.2004.tb02451.x.

Rusjan S, Mikos M. 2010. Seasonal variability of diurnal in-stream nitrate concentration oscillations under hydrologically stable conditions. Biogeochemistry, 97(2-3): 123140. 10.1007/s10533-009-9361-5.

Schincariol RA, McNeil JD. 2002. Errors with small volume elastic seepage meter bags. Ground Water, 40(6): 649-651. 10.1111/j.1745-6584.2002.tb02551.x.

Simmons RC, Gold AJ, Groffman PM. 1992. Nitrate dynamics in riparian forests: groundwater studies. Journal of Environmental Quality, 21(4): 659-665.

Spalding RF, Exner ME. 1993. Occurrence of nitrate in groundwater--A review. Journal of Environmental Quality, 22: 392-402.

Szilagyi J, Gribovszki Z, Kalicz P, Kucsara M. 2008. On diurnal riparian zone groundwaterlevel and streamflow fluctuations. Journal of Hydrology, 349(1-2): 1-5. 10.1016/j.jhydrol.2007.09.014.

USDA. 2002. 2002 Census of Agriculture. U. S. Department of Agriculture. 
Valett HM, Morrice JA, Dahm CN, Campana ME. 1996. Parent lithology, surfacegroundwater exchange, and nitrate retention in headwater streams. Limnology and Oceanography, 41(2): 333-345.

Warwick J, Hill AR. 1988. Nitrate Depletion in the Riparian Zone of a Small Woodland Stream. Hydrobiologia, 157(3): 231-240.

Willems HPL, Rotelli MD, Berry DF, Smith EP, Reneau RB, Mostaghimi S. 1997. Nitrate removal in riparian wetland soils: Effects of flow rate, temperature, nitrate concentration and soil depth. Water Research, 31(4): 841-849.

Winter TC, Harvey JD, Franke OL, Alley WM. 1998. Ground water and Surface Water: A Single Resource. U.S. Geological Survey Circular 1139, US Geological Survey, Denver, CO. 
Appendix A, Page 59

1 Appendix A. Inseepage results for individual seepage meters for June, 2010 


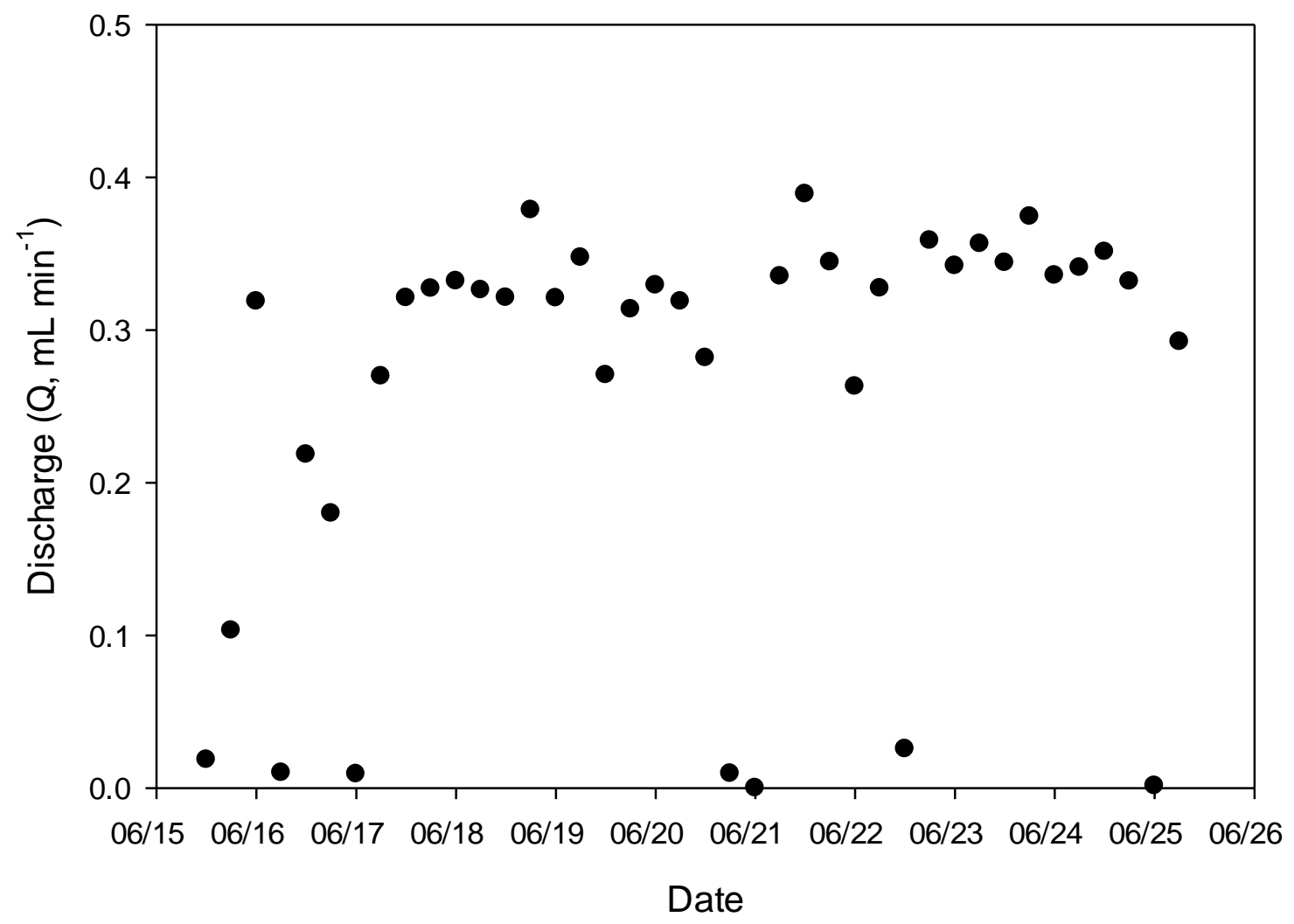

Appendix A. 1 Seepage meter 1 - June 


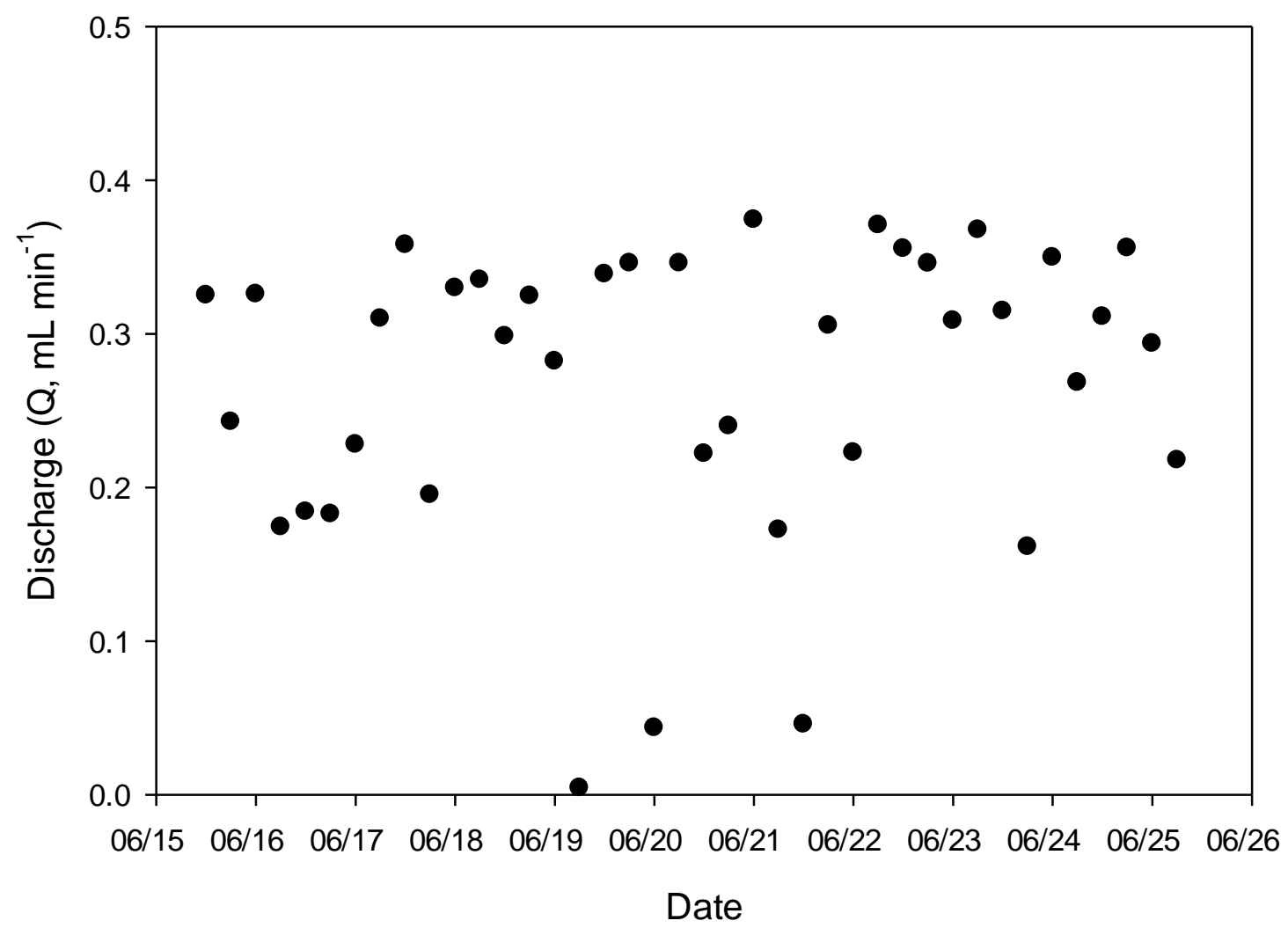

Appendix A. 2 SM2-June 
Appendix A, Page 62

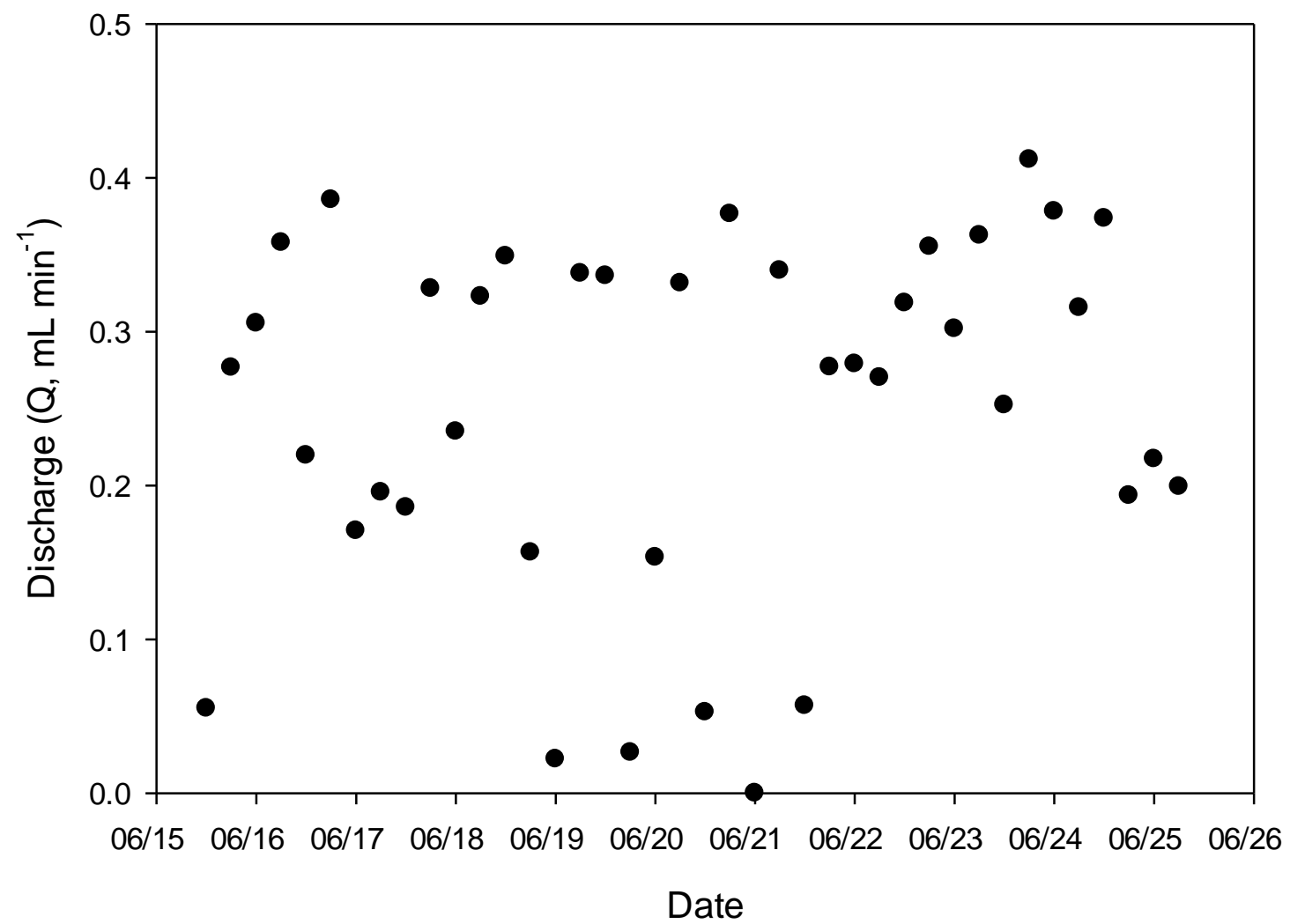

Appendix A. 3 SM2A-June 
Appendix A, Page 63

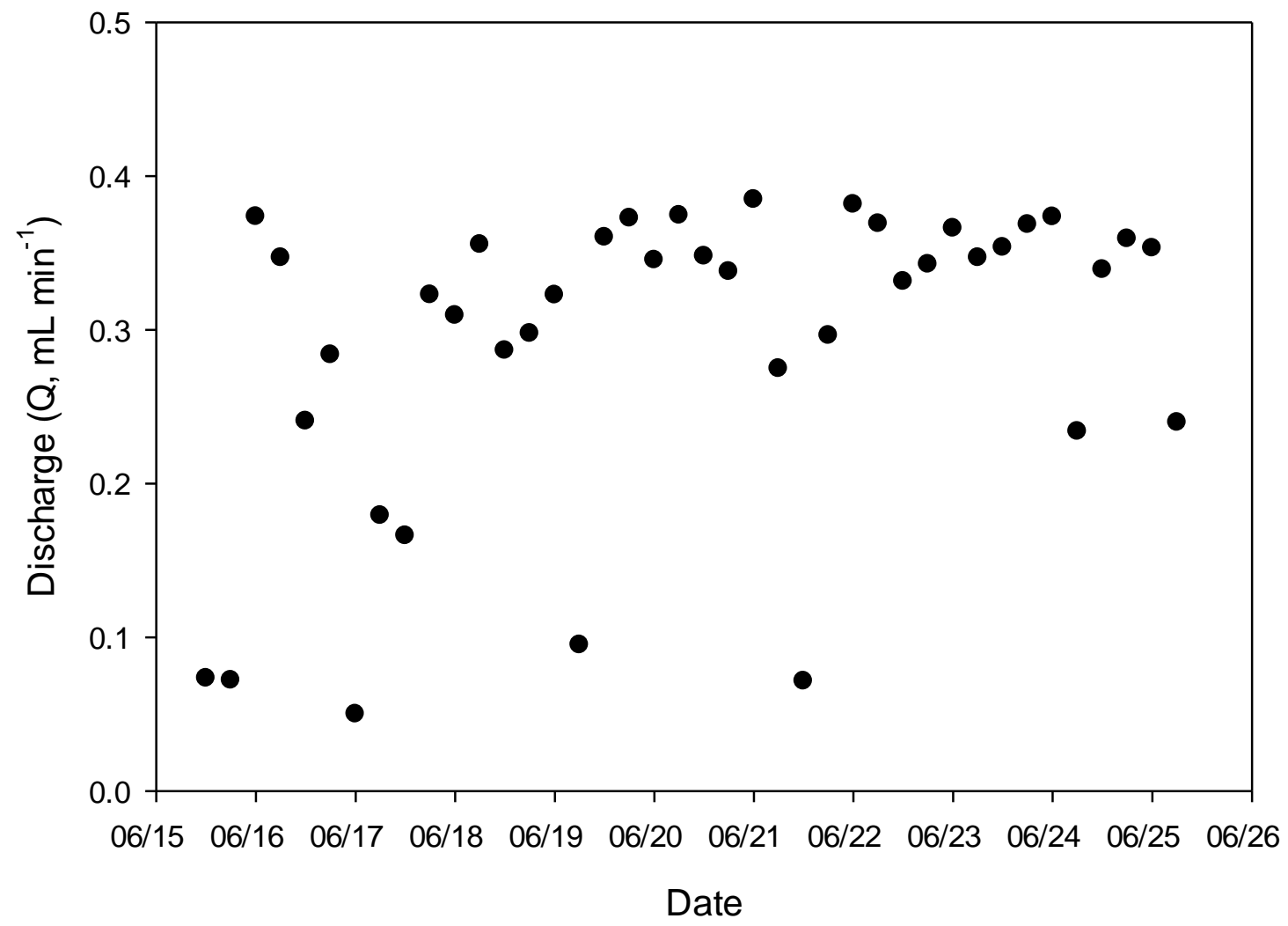

Appendix A. 4 SM2B - June 
Appendix A, Page 64

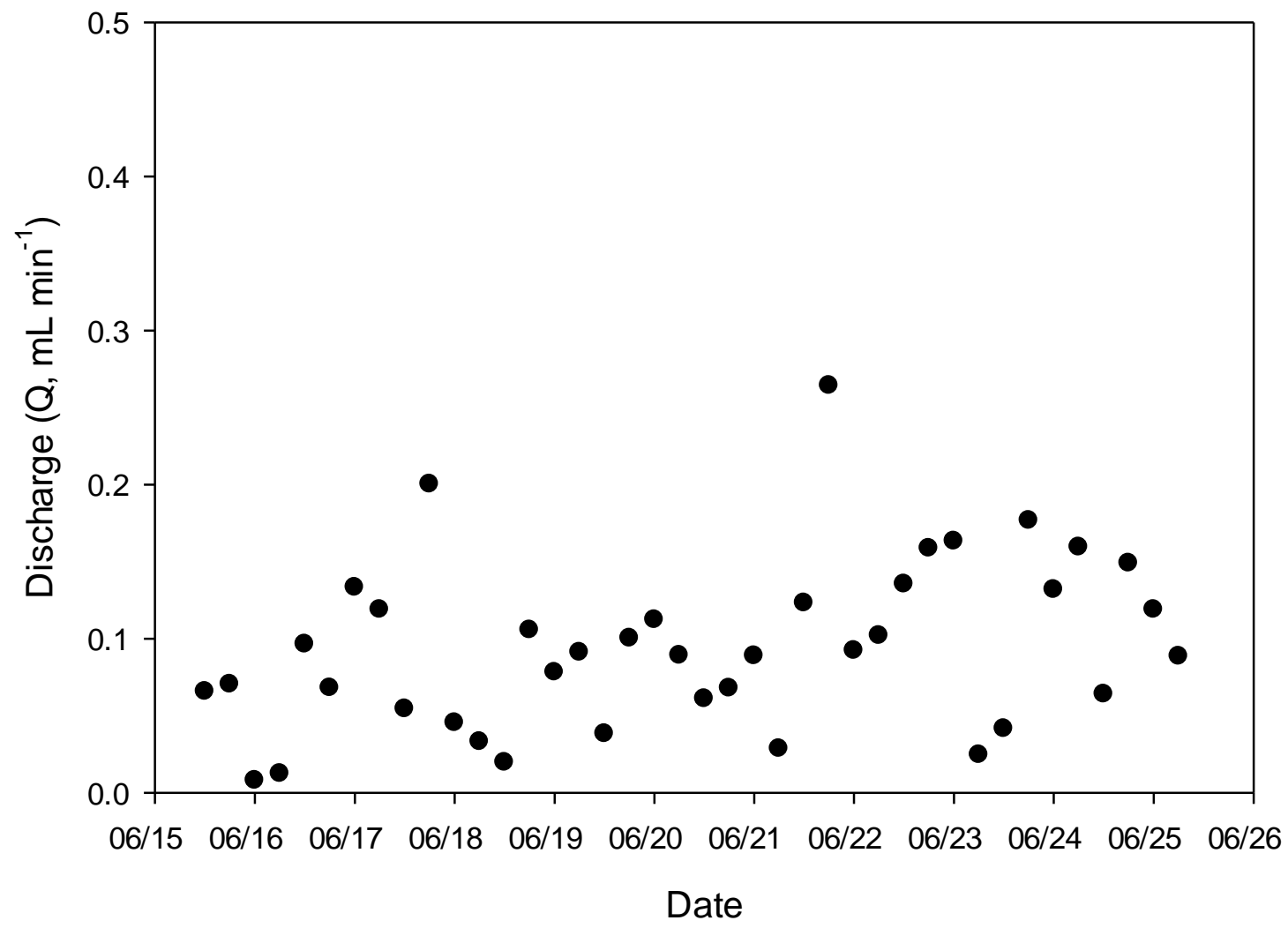

Appendix A. 5 SM3 - June 
Appendix A, Page 65

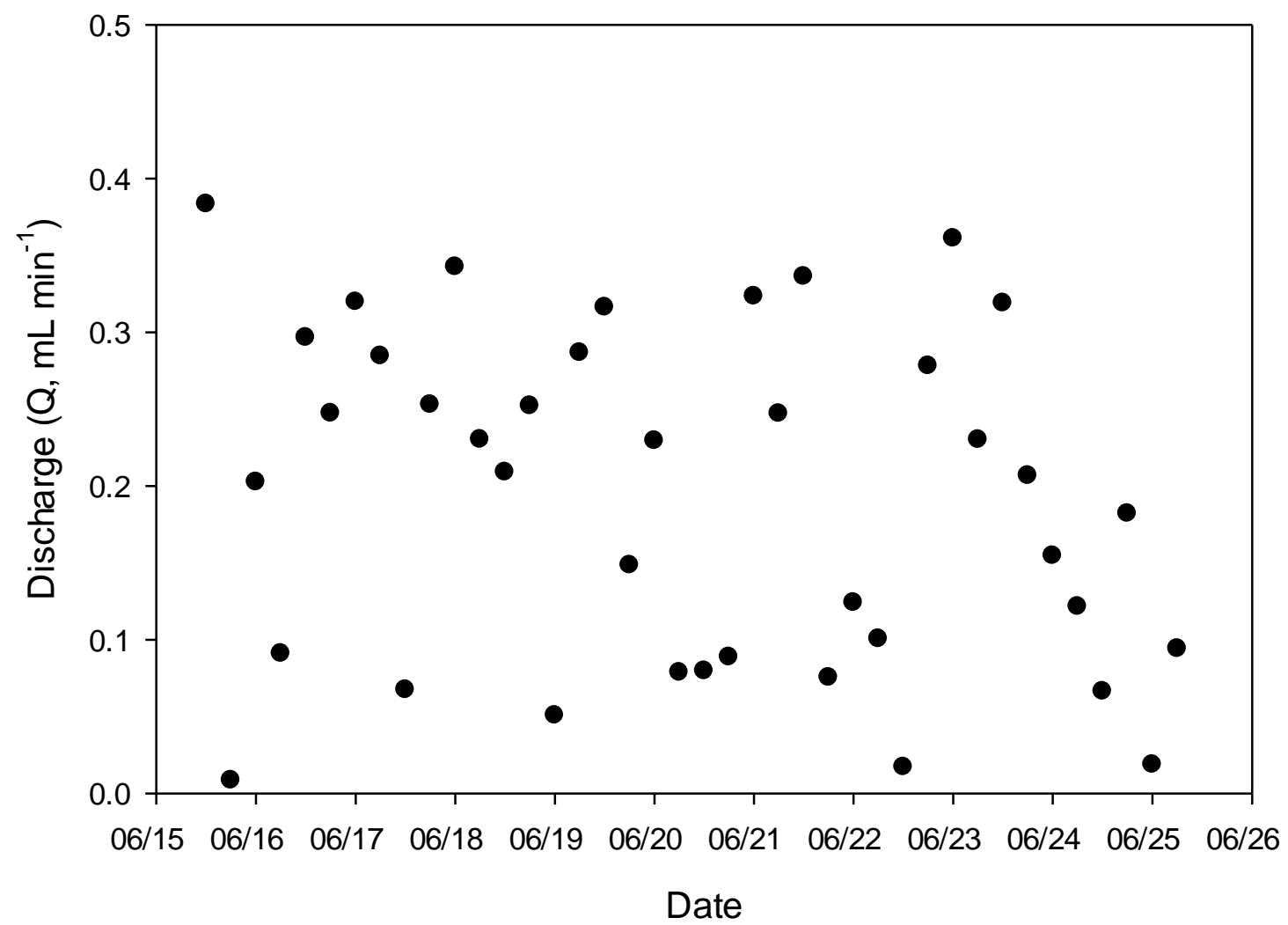

Appendix A. 6 SM4 -June 
Appendix A, Page 66

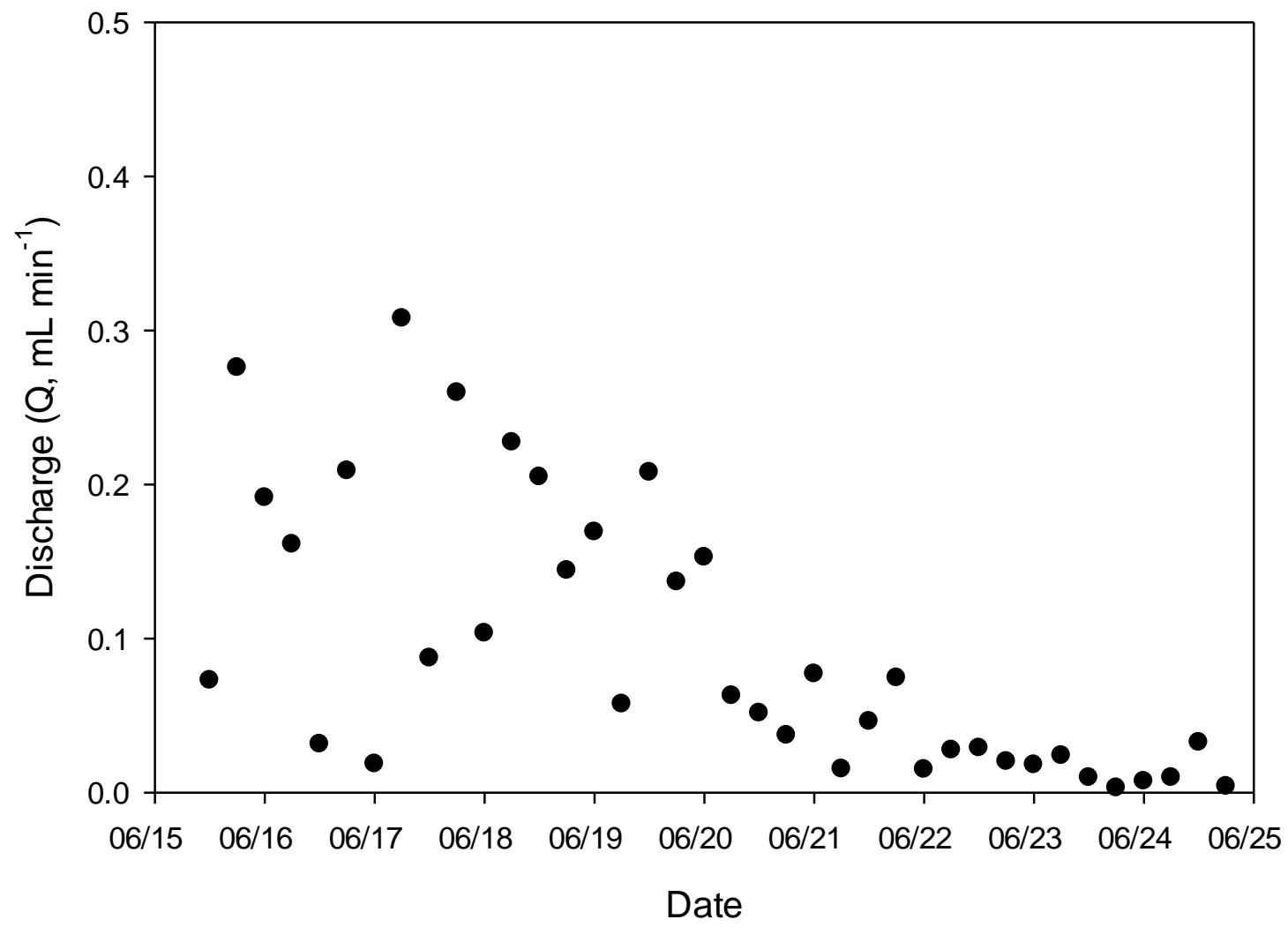

Appendix A. 7 SM 5 - June 
Appendix A, Page 67

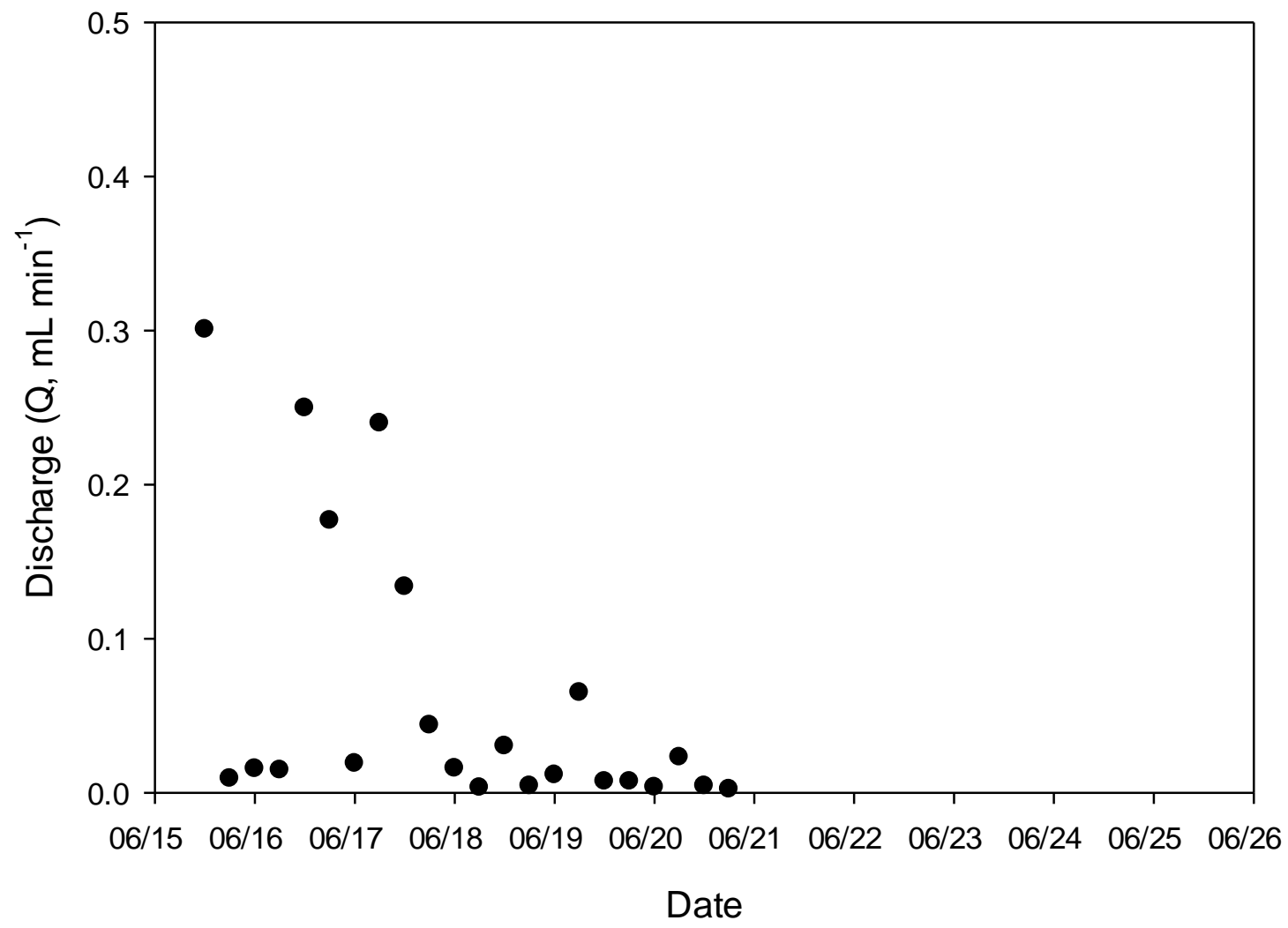

Appendix A. 8 SM 5a - June 
Appendix A, Page 68

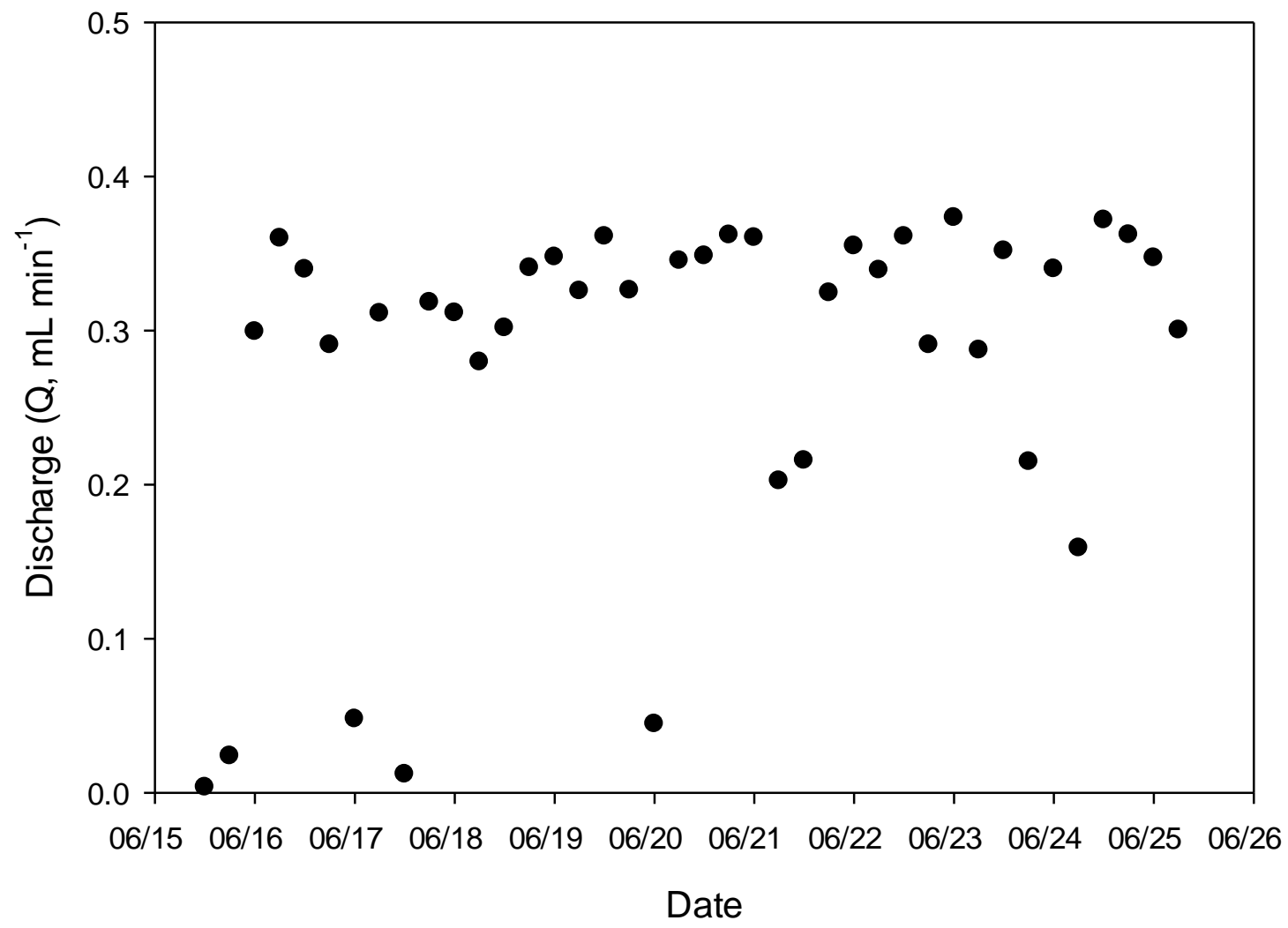

Appendix A. 9 SM 5b - June 
Appendix A, Page 69

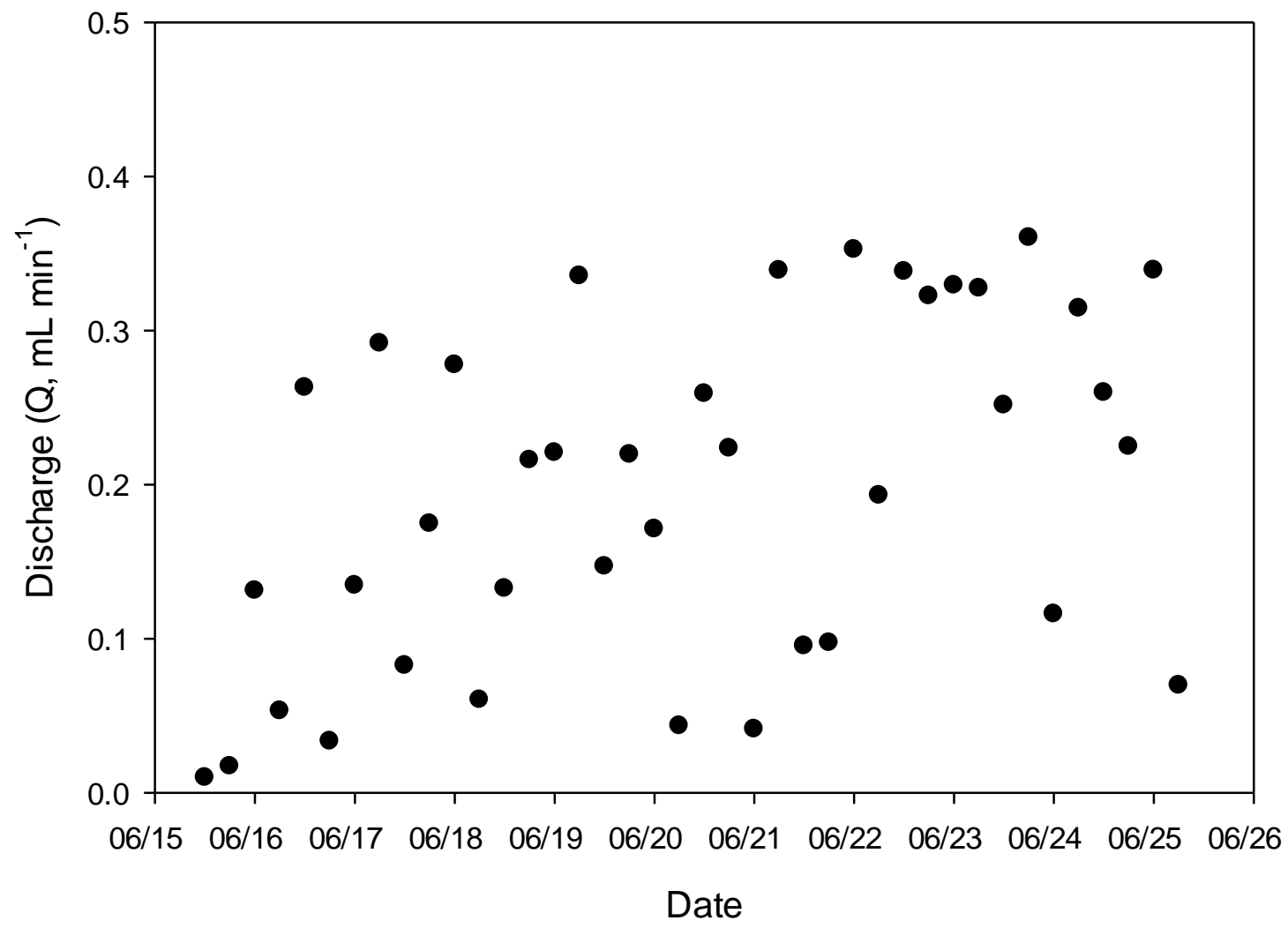

Appendix A. 10 SM 6 - June 
Appendix A, Page 70

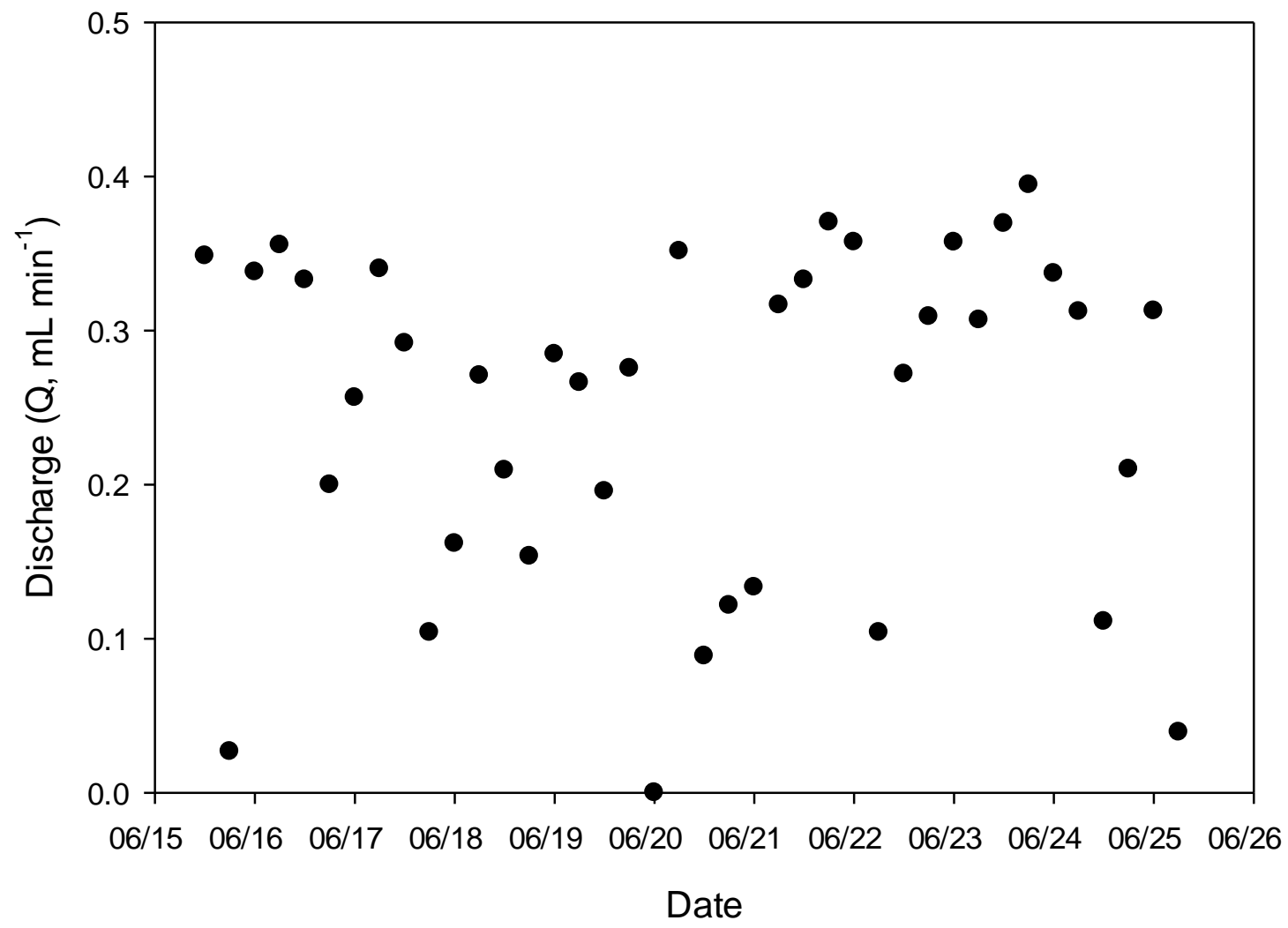

Appendix A. 11 SM 7 - June 
Appendix A, Page 71

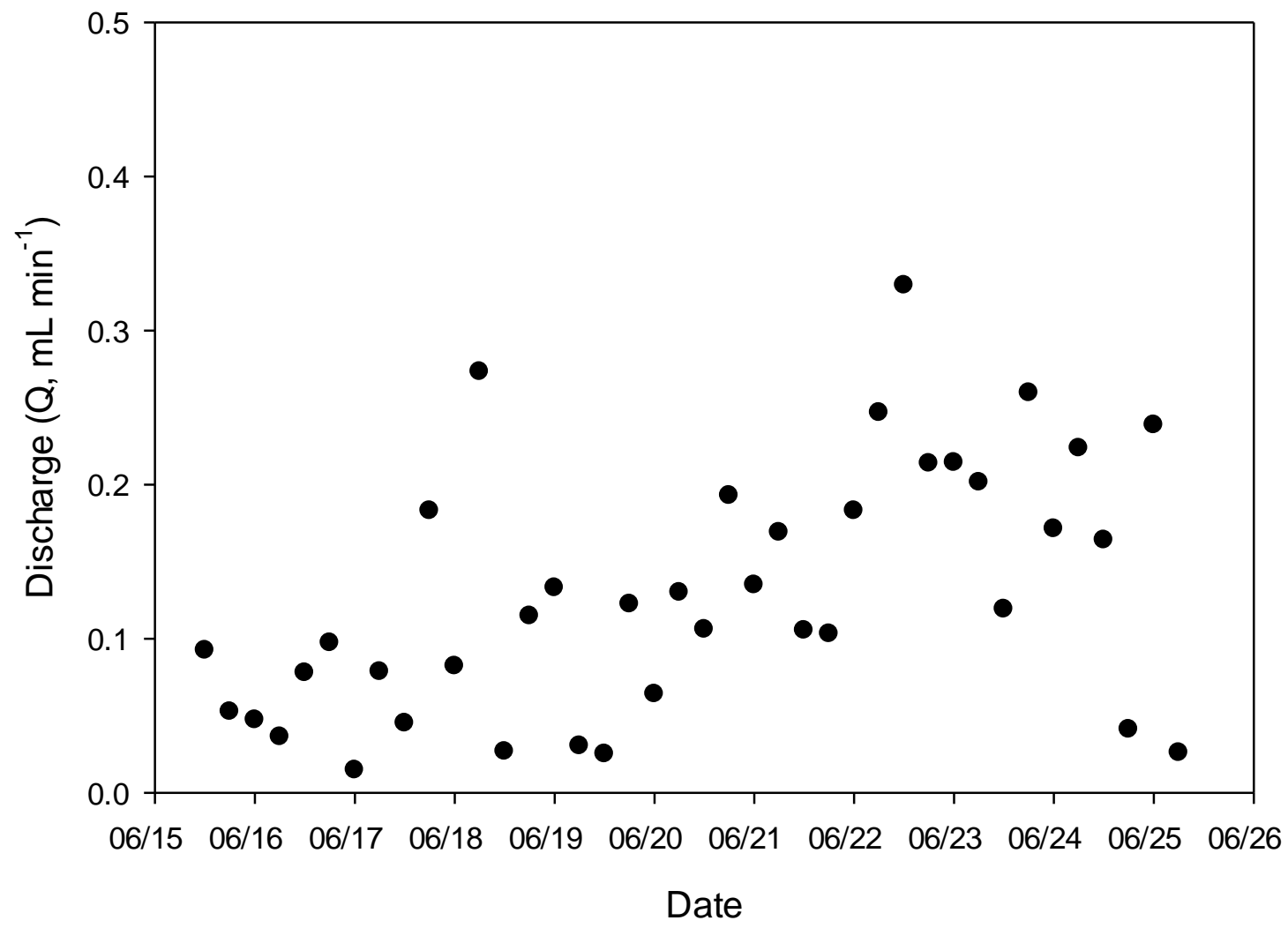

Appendix A. 12 SM 8 - June 
Appendix A, Page 72

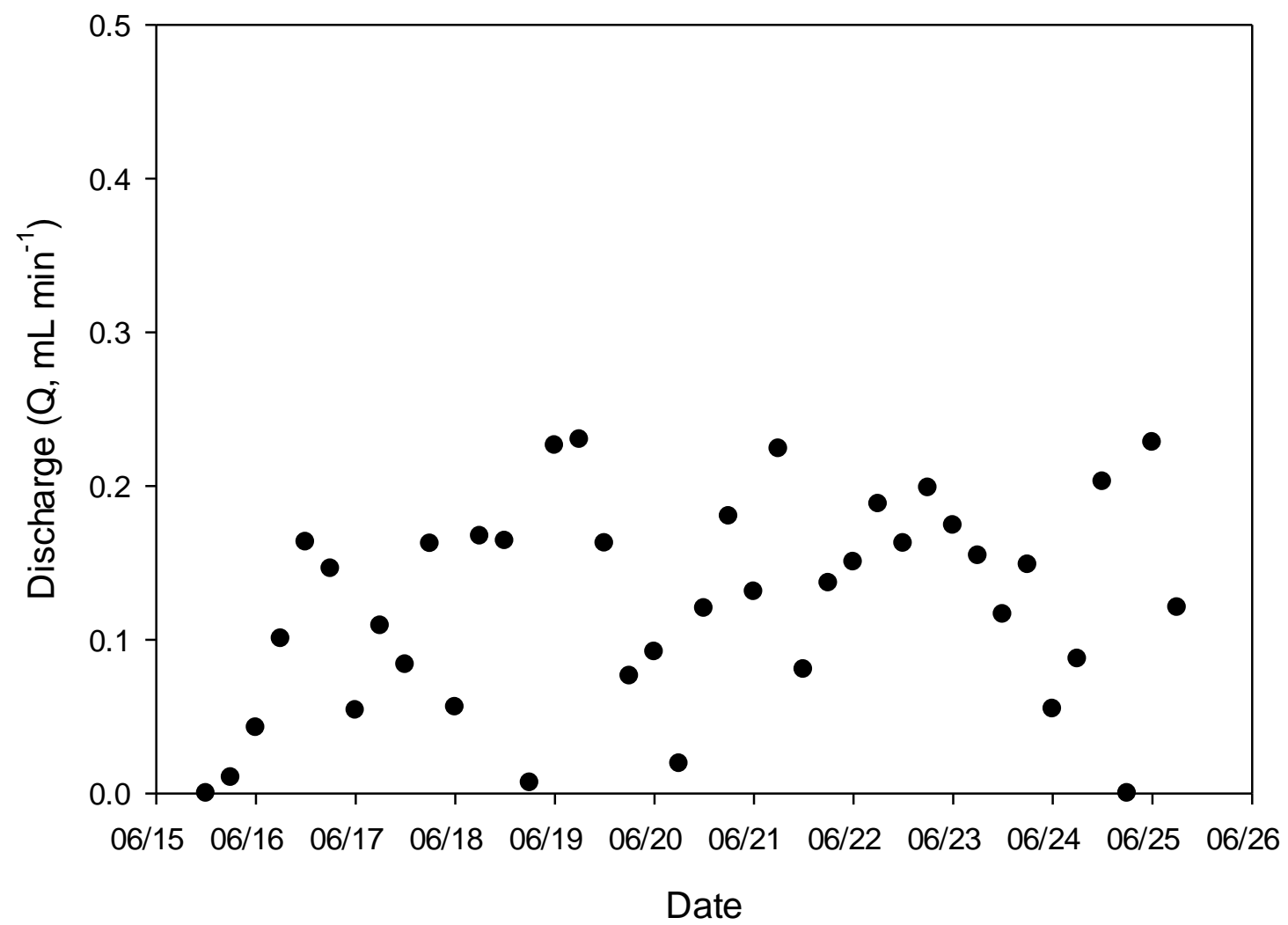

Appendix A. 13 SM 8a-June 


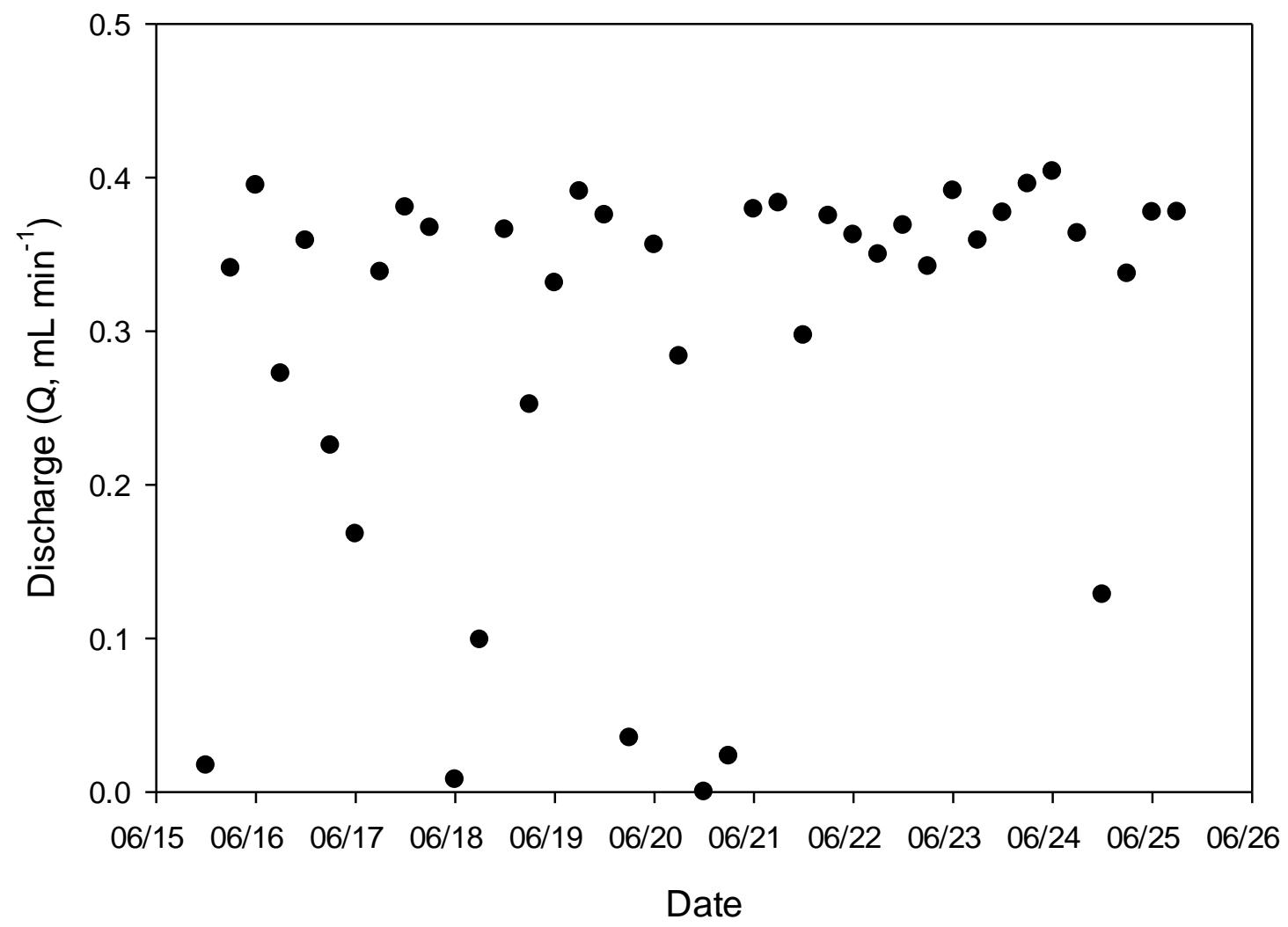

Appendix A. 14 SM 8b - June 
Appendix A, Page 74

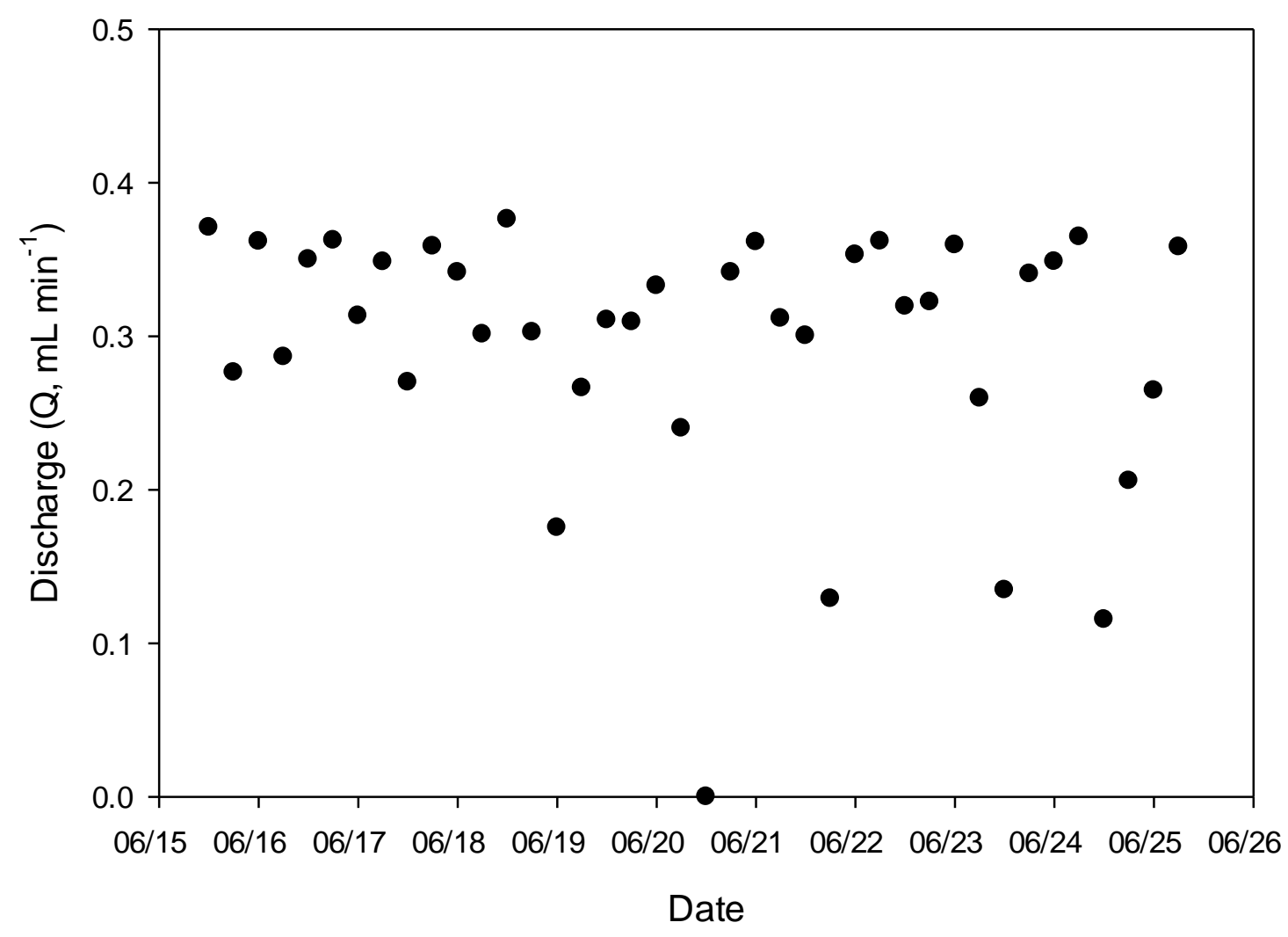

Appendix A. 15 
Appendix B, Page 75

2 Appendix B. Inseepage results for individual seepage meters, September, 2010 
Appendix B, Page 76

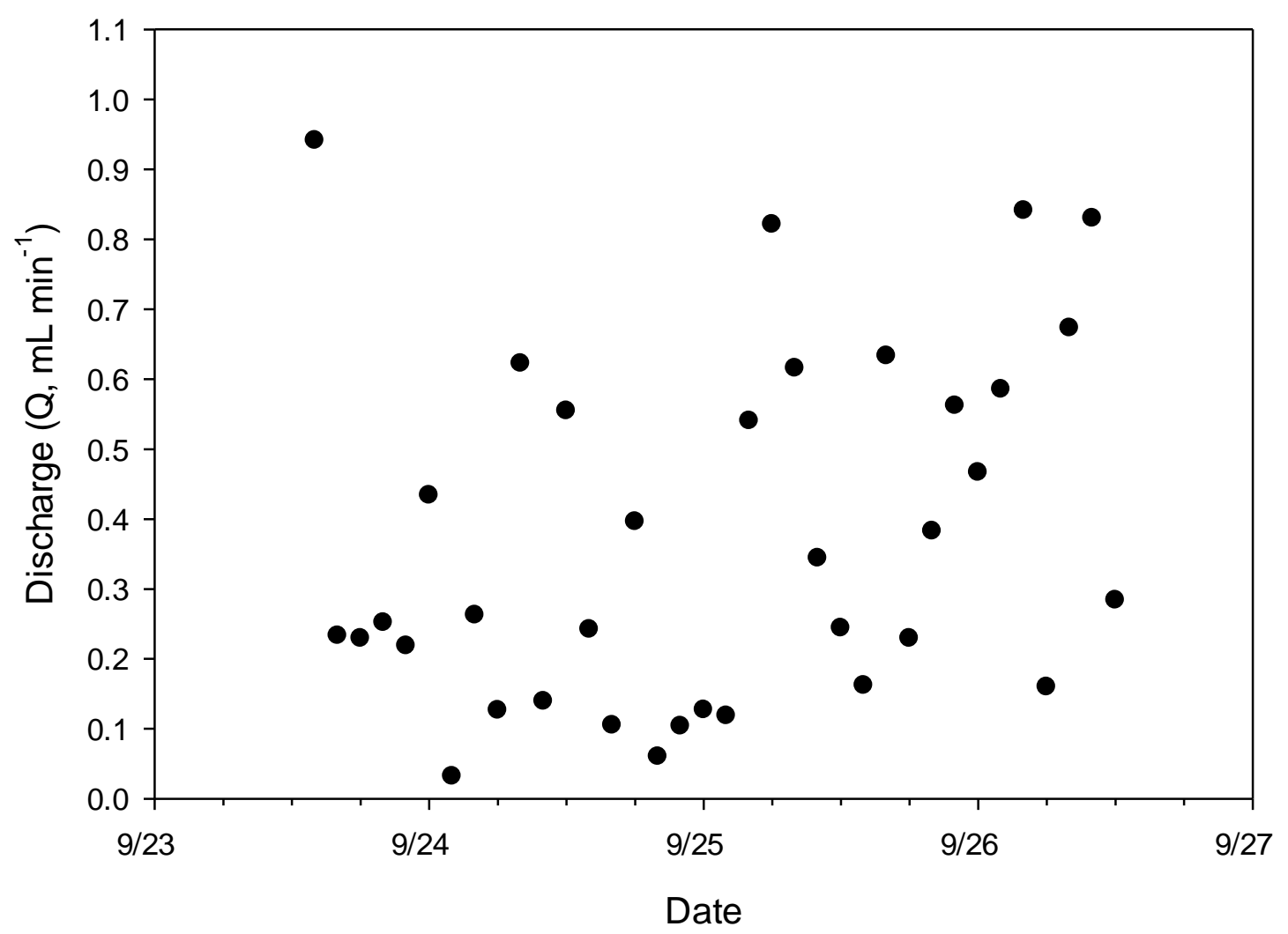

Appendix B. 1 SM A - September 
Appendix B, Page 77

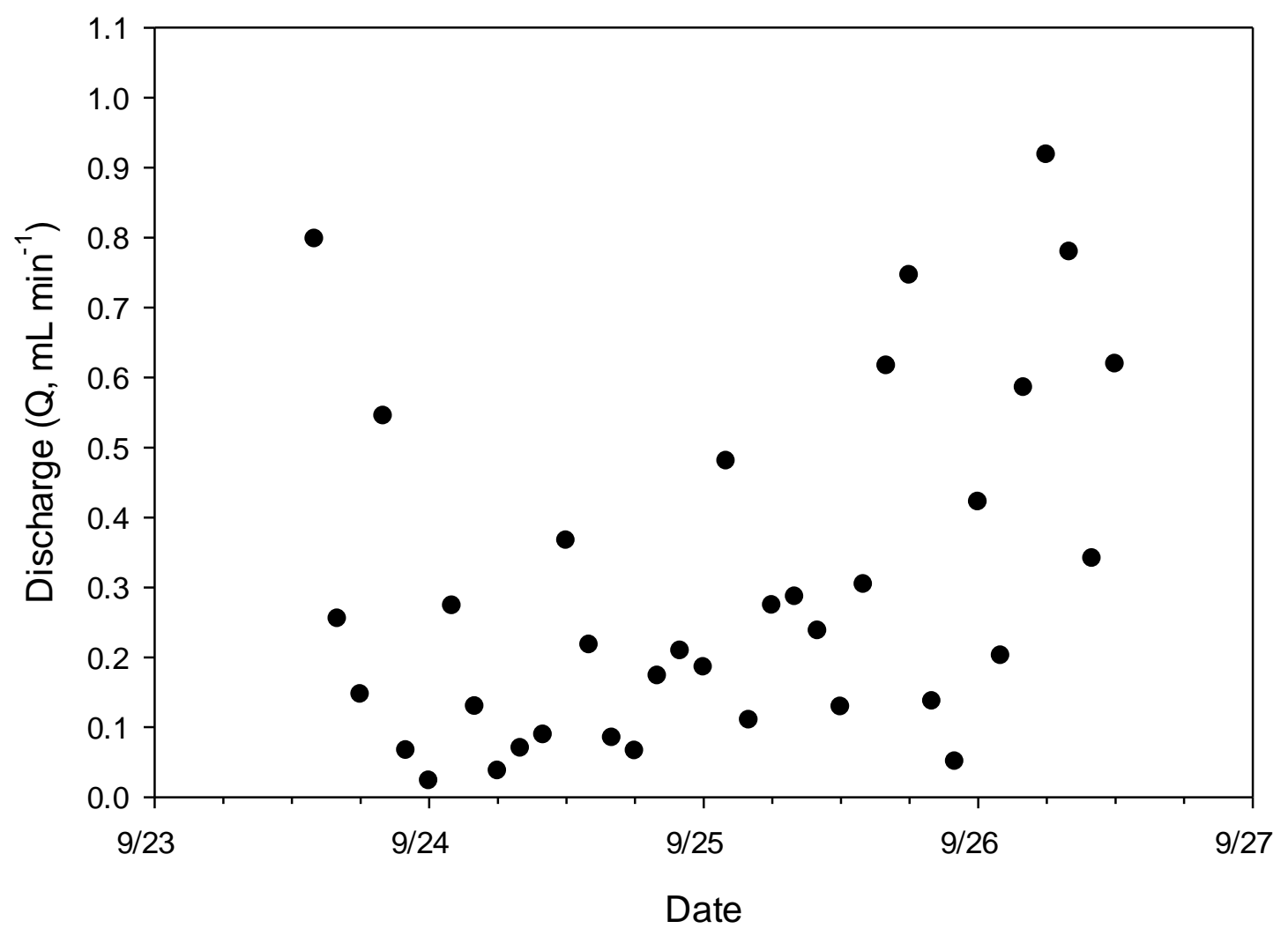

Appendix B. 2 SM B - September 
Appendix B, Page 78

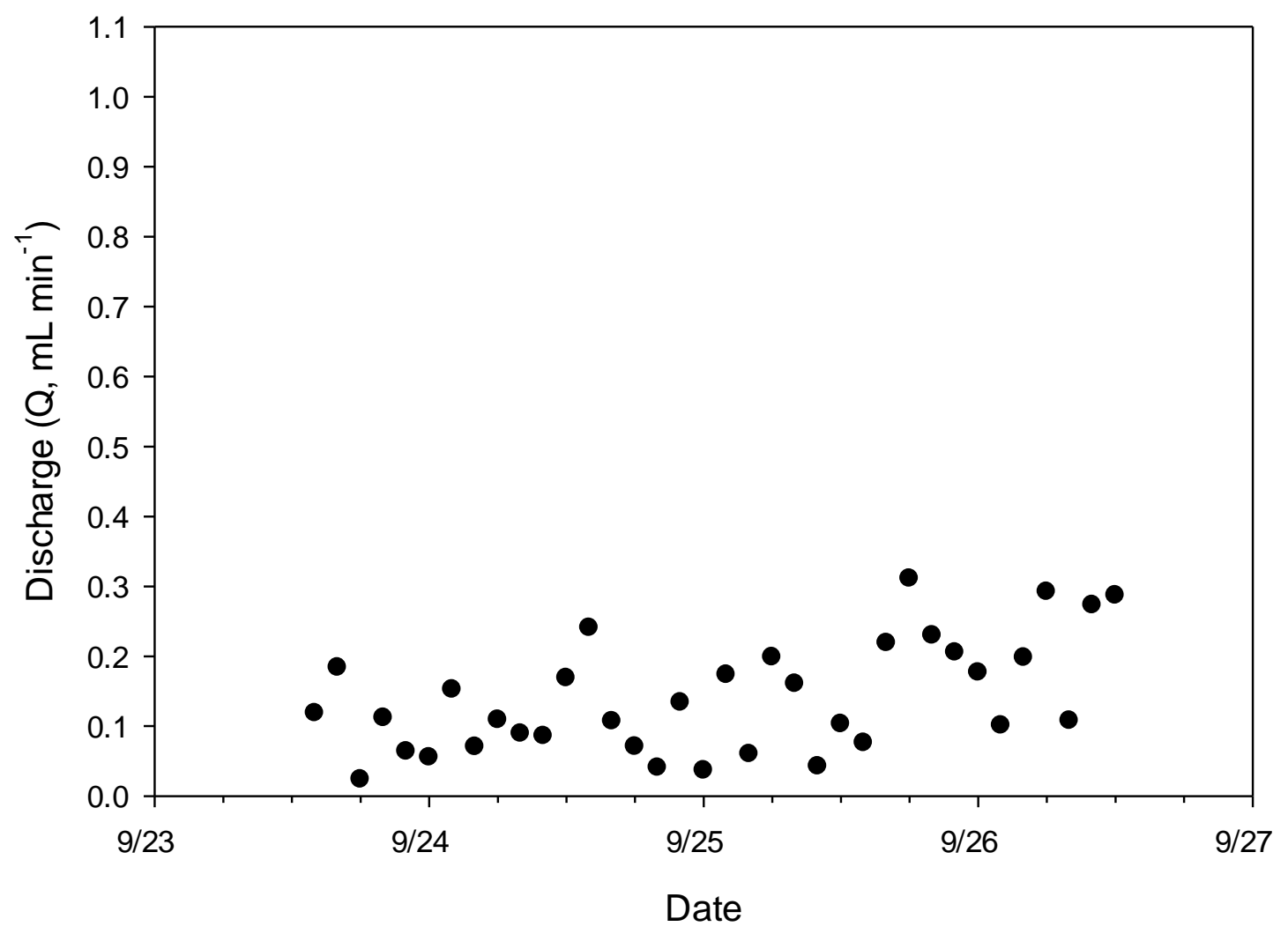

Appendix B. 3 SM C - September 
Appendix B, Page 79

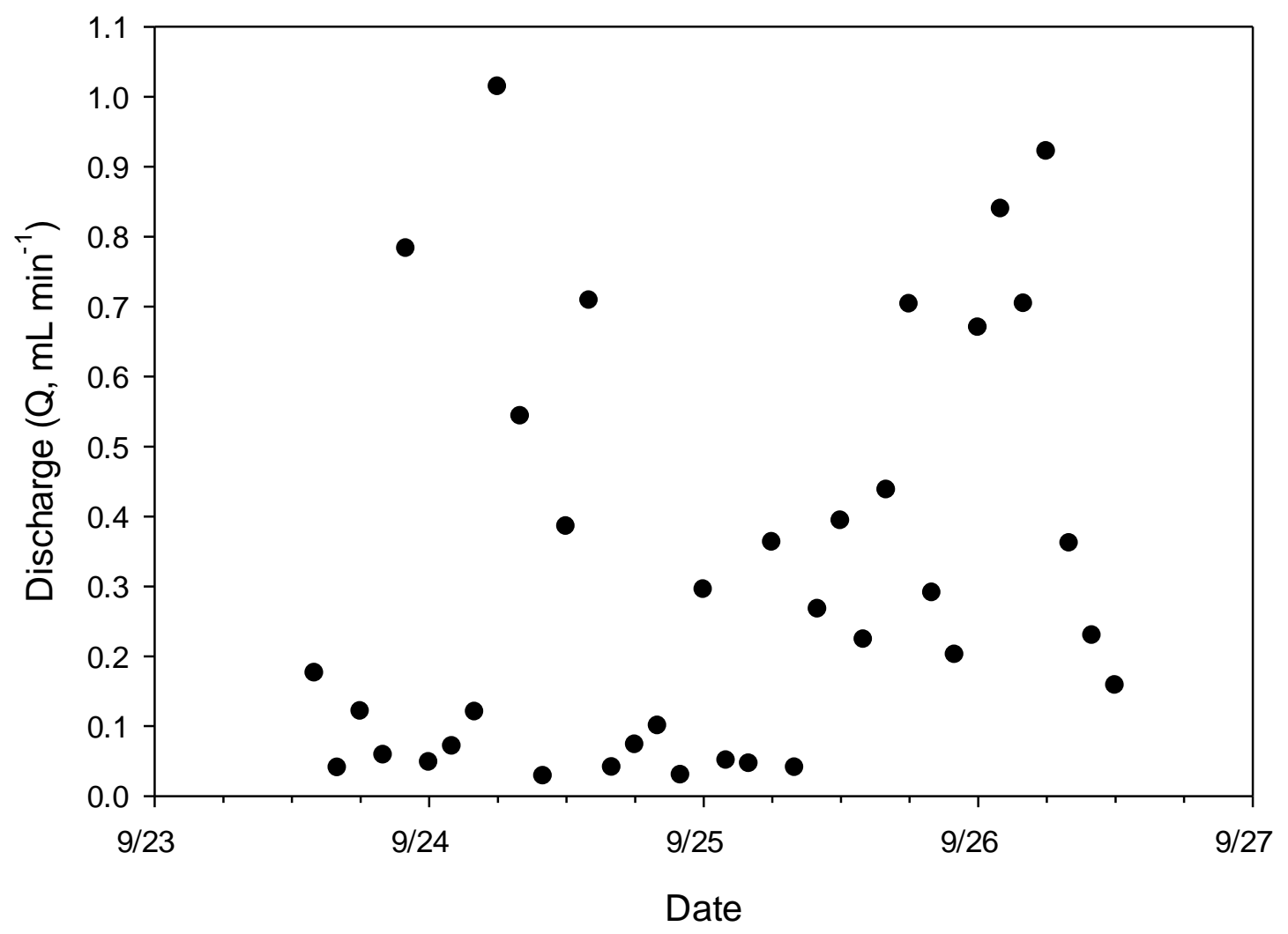

Appendix B. 4 SM D - September 
Appendix B, Page 80

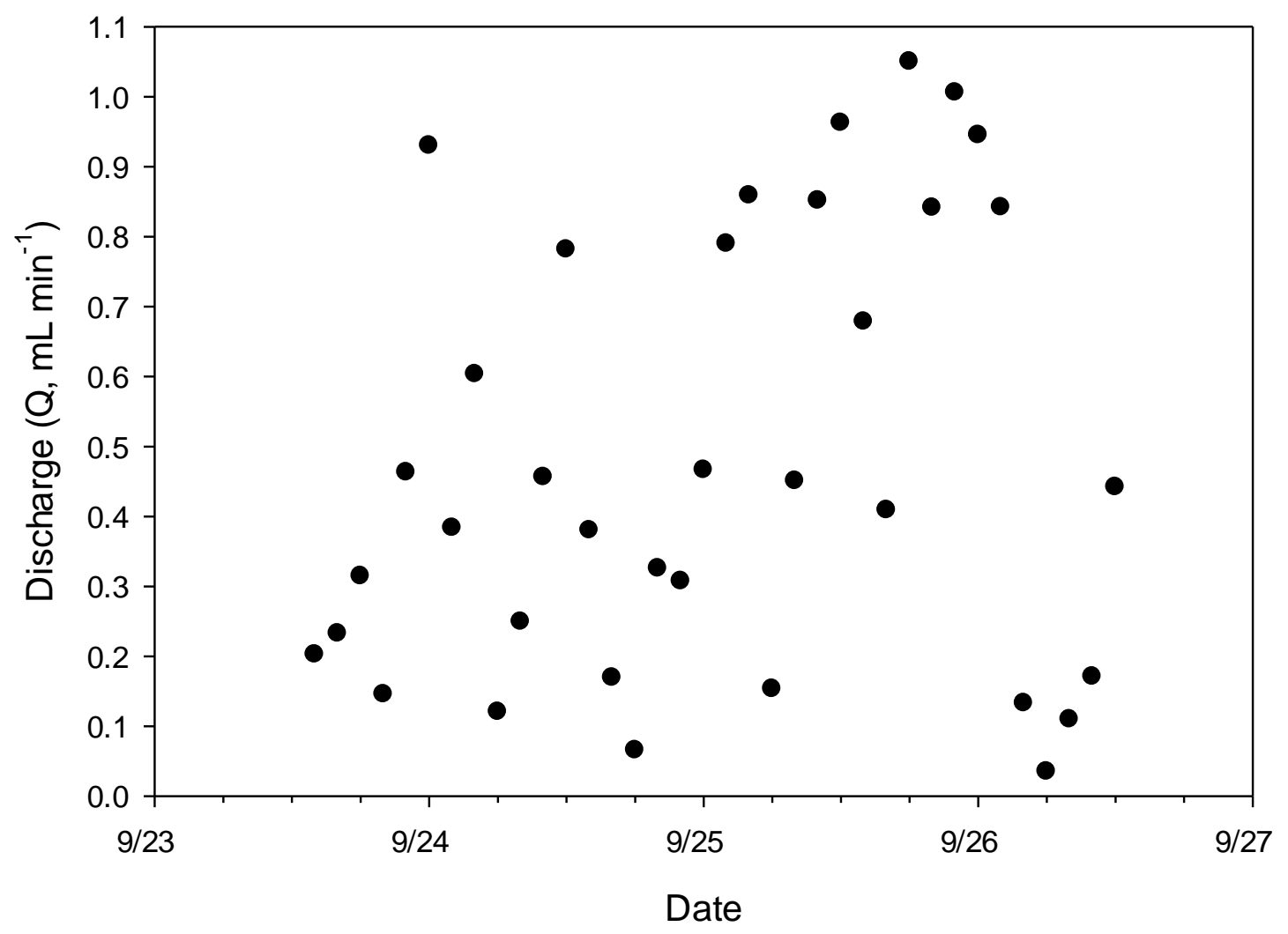

Appendix B. 5 SM E - September 
Appendix B, Page 81

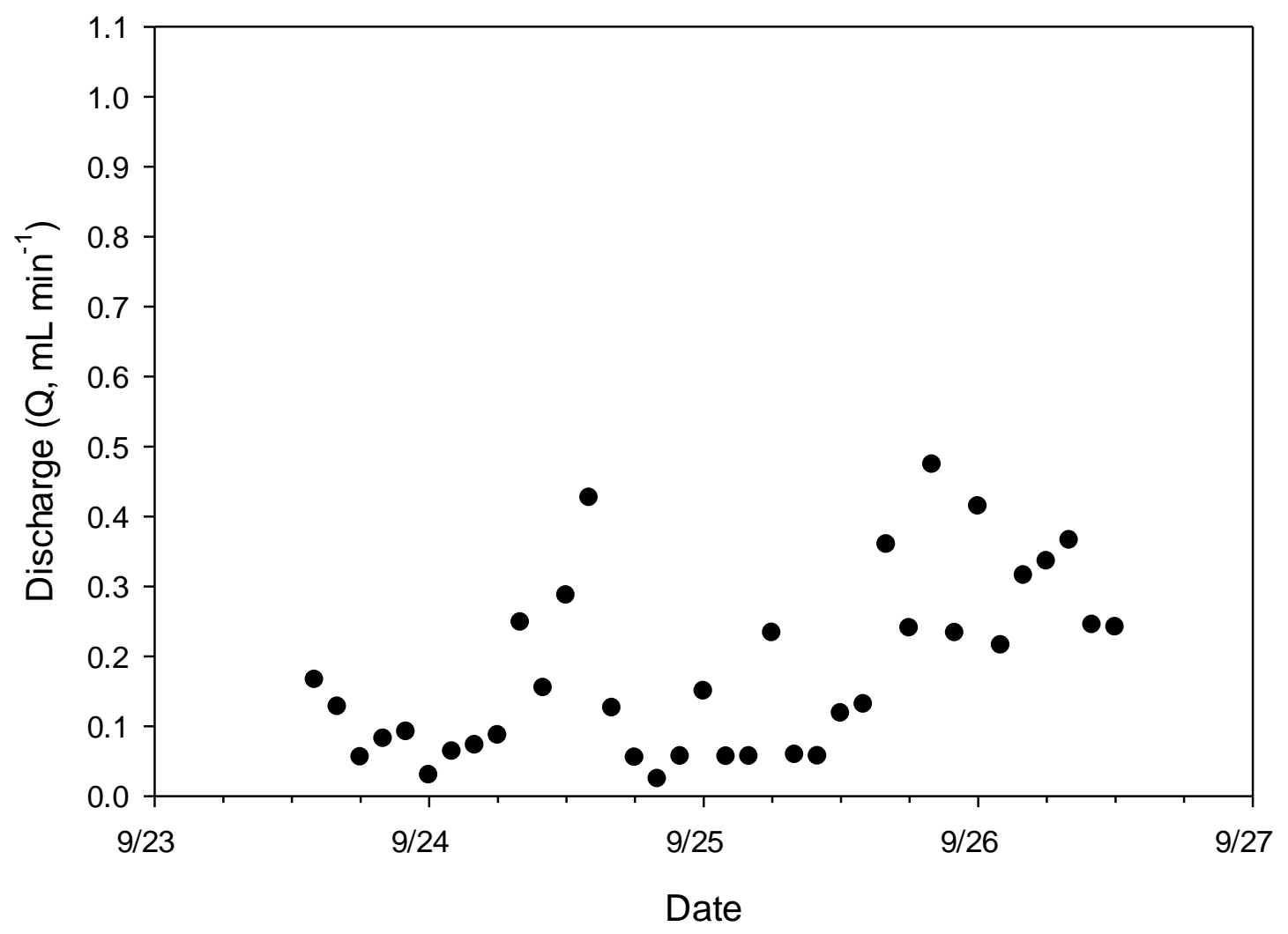

Appendix B. 6 SM F September 
3 Appendix $\mathrm{C}$. Concentration of $\mathrm{NO}_{3}{ }^{-}$in inseepage collected from individual meters in June, 2010. 
Appendix C, Page 83

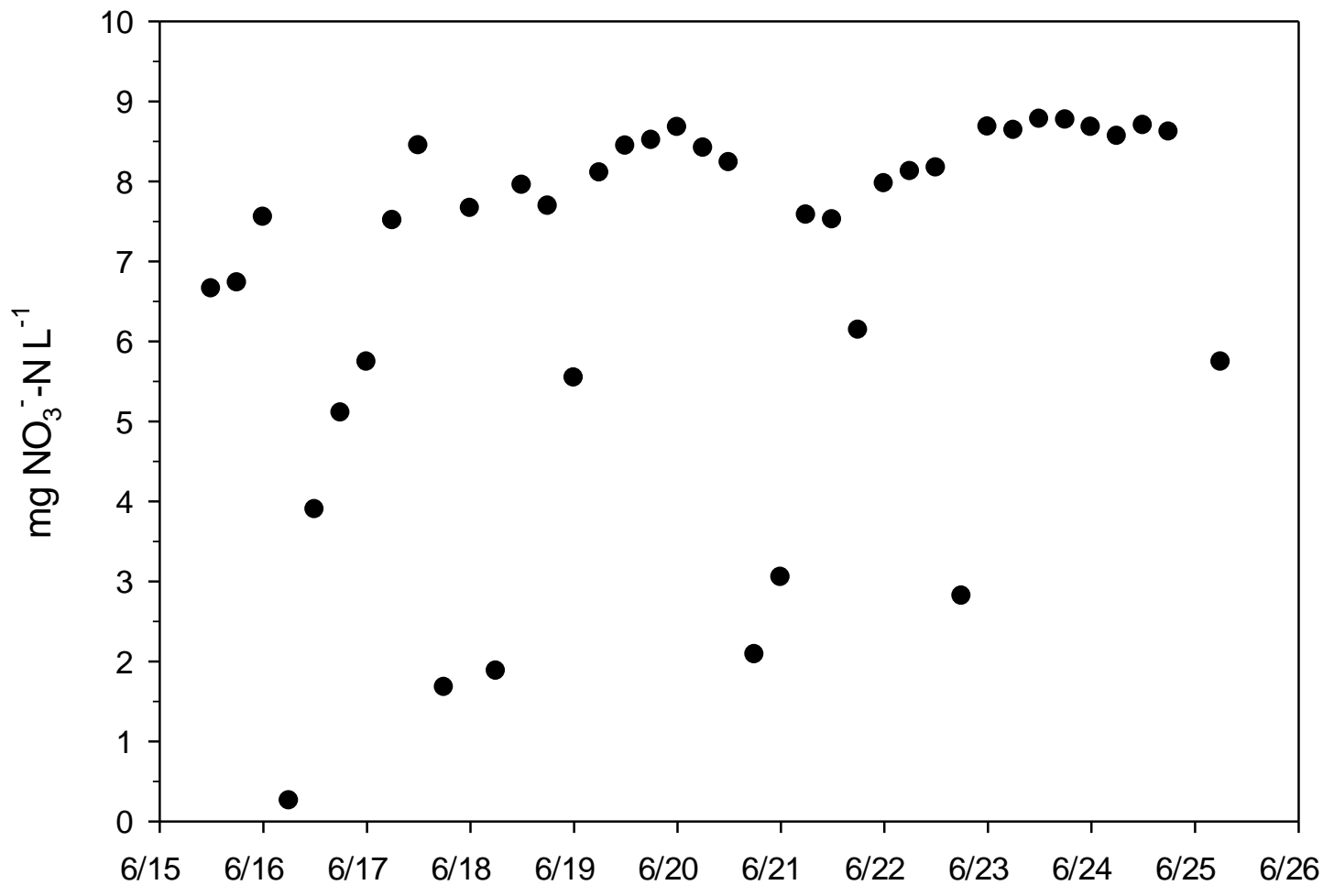

Appendix C. $1 \mathrm{SM} 1$ June $\mathrm{NO}_{3}{ }^{-}$ 
Appendix C, Page 84

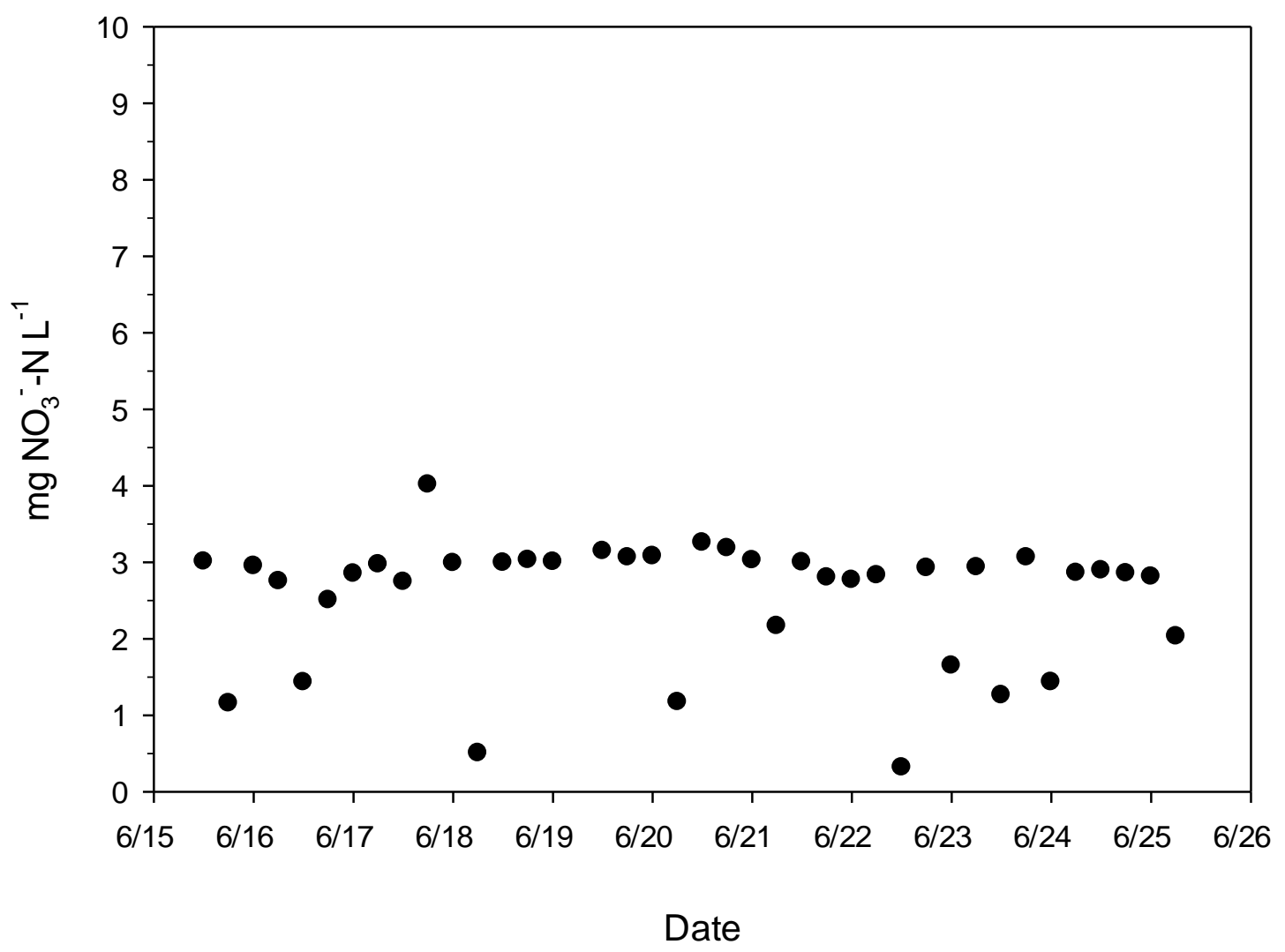

Appendix C. $2 \mathrm{SM} 2 \mathrm{NO}_{3}{ }^{-}$June 
Appendix C, Page 85

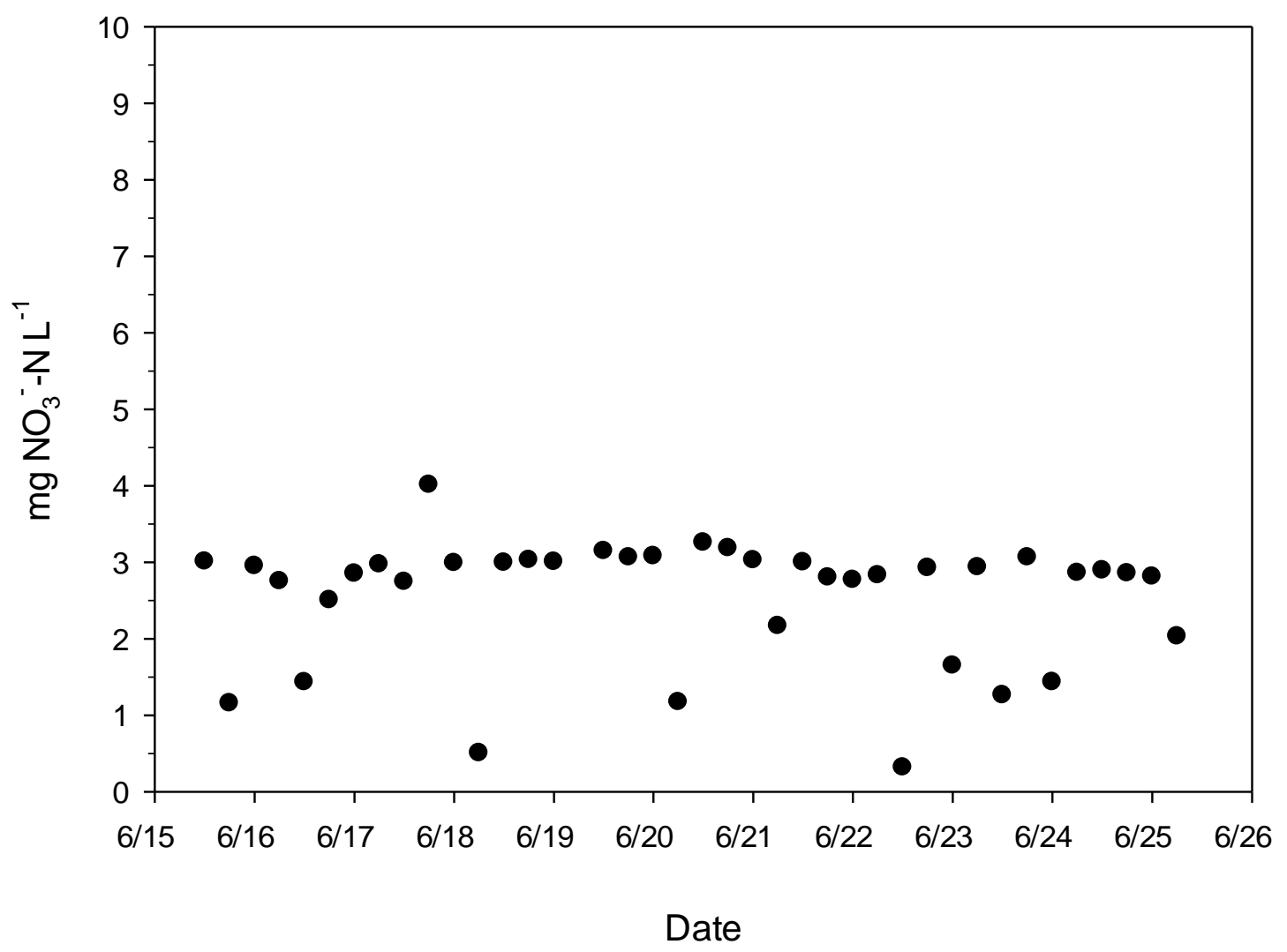

Appendix C. $3 \mathrm{SM} 2 \mathrm{a} \mathrm{NO}_{3}{ }^{-}$June 
Appendix C, Page 86

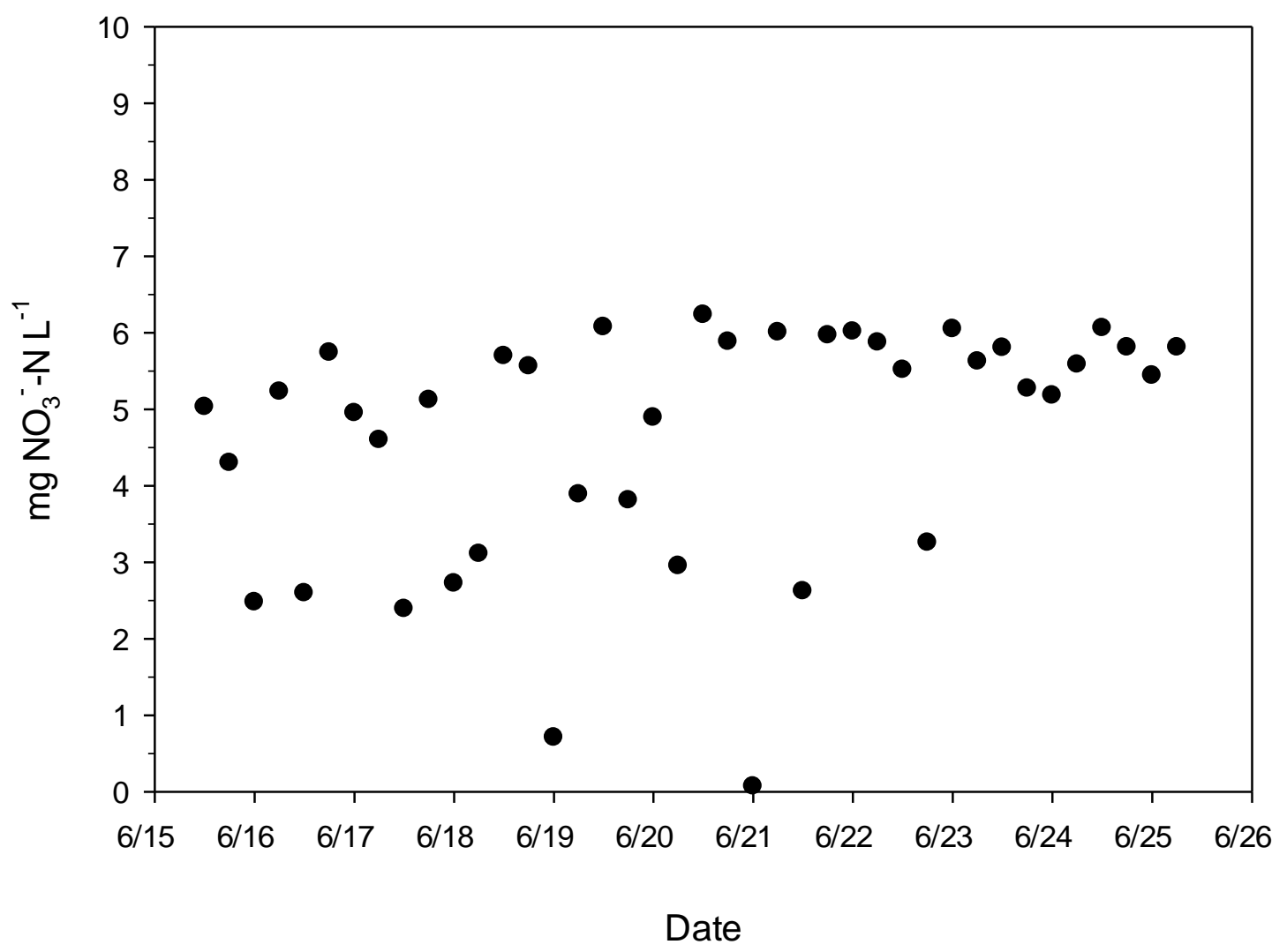

Appendix C. $4 \mathrm{SM} 2 \mathrm{~b} \mathrm{NO}_{3}^{-}$June 


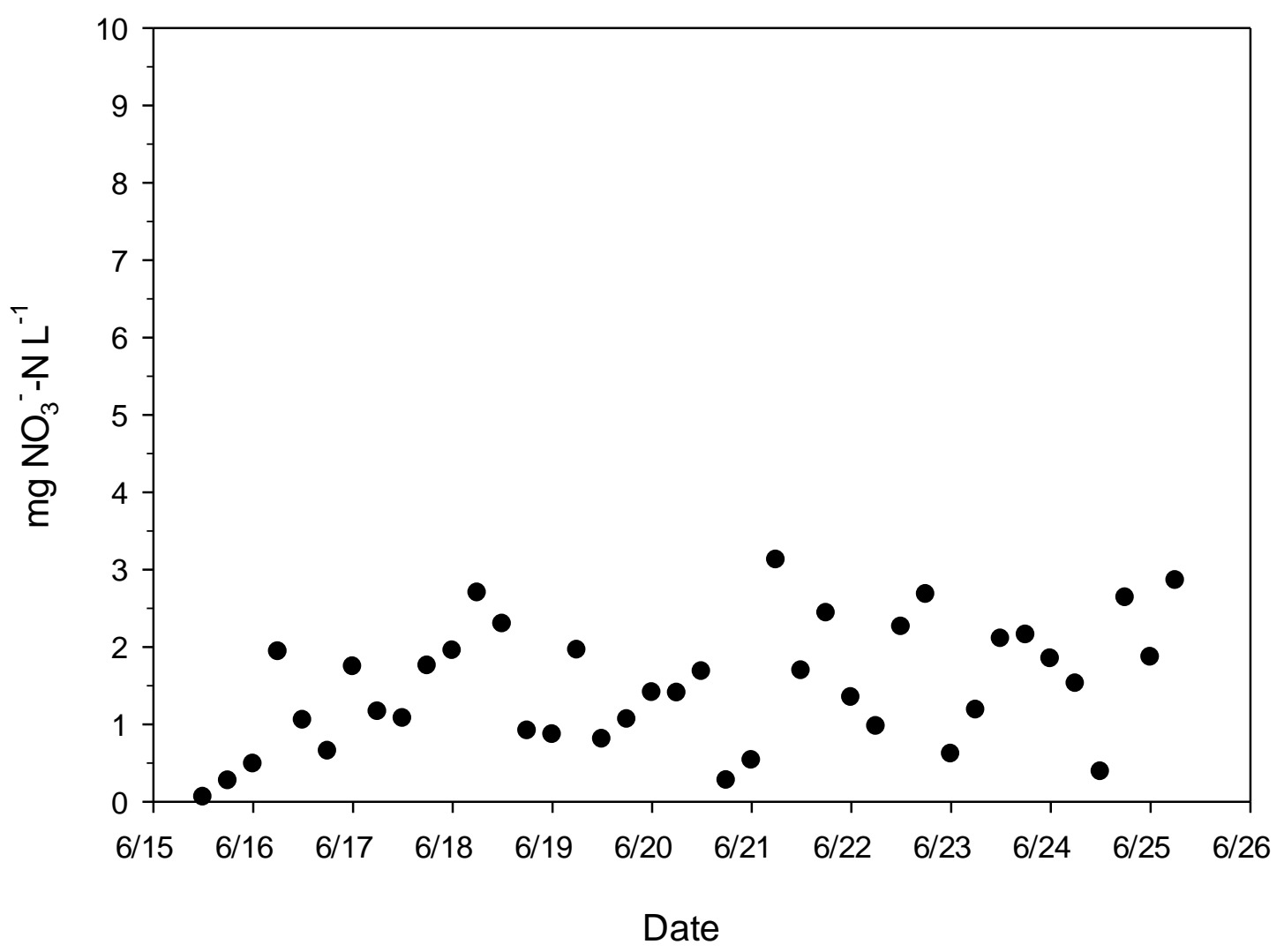

Appendix C. $5 \quad \mathrm{SM} 3 \quad \mathrm{NO}_{3}^{-}$June 
Appendix C, Page 88

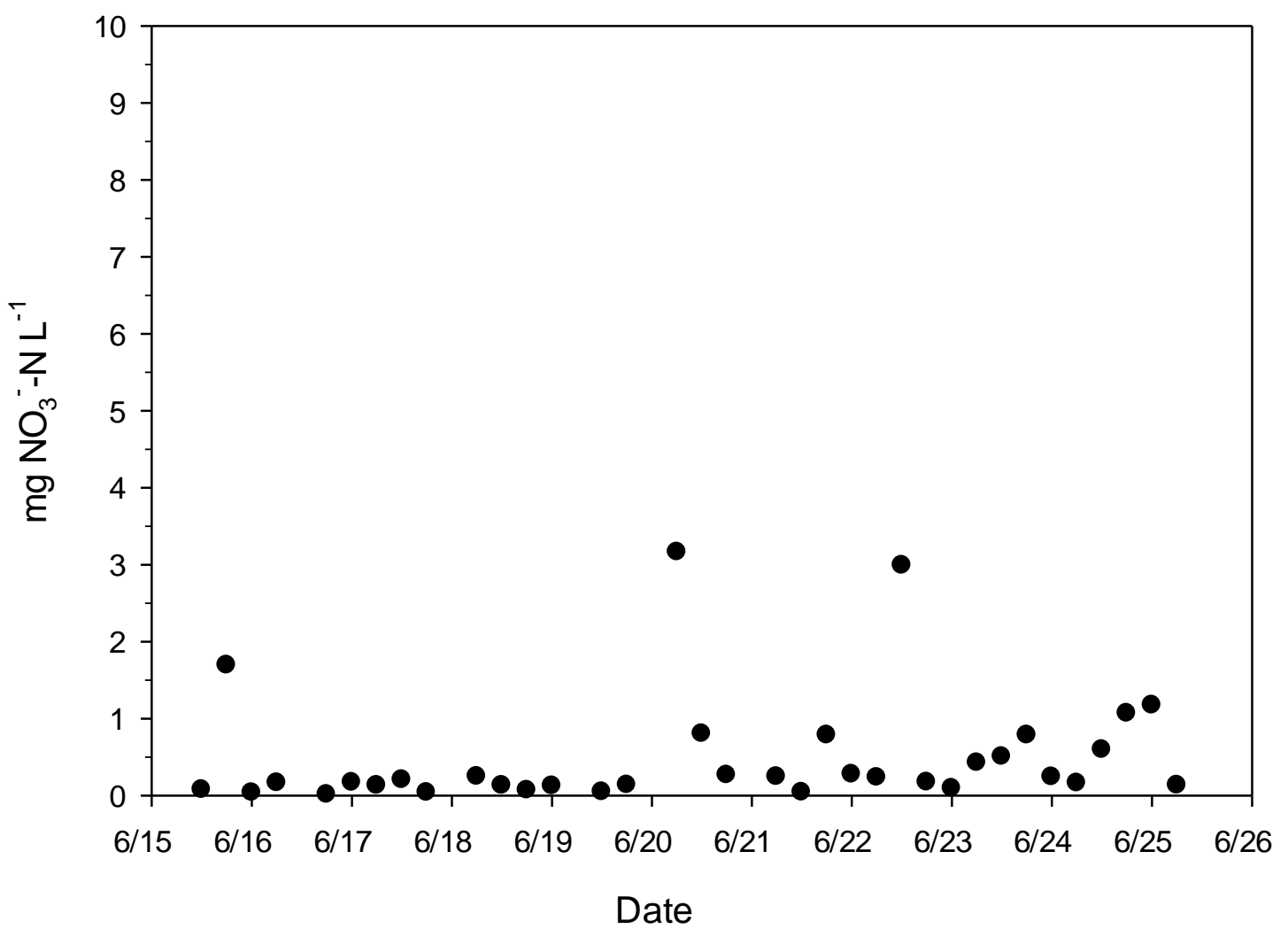

Appendix C. $6 \mathrm{SM}_{4} \mathrm{NO}_{3}{ }^{-}$June 
Appendix C, Page 89

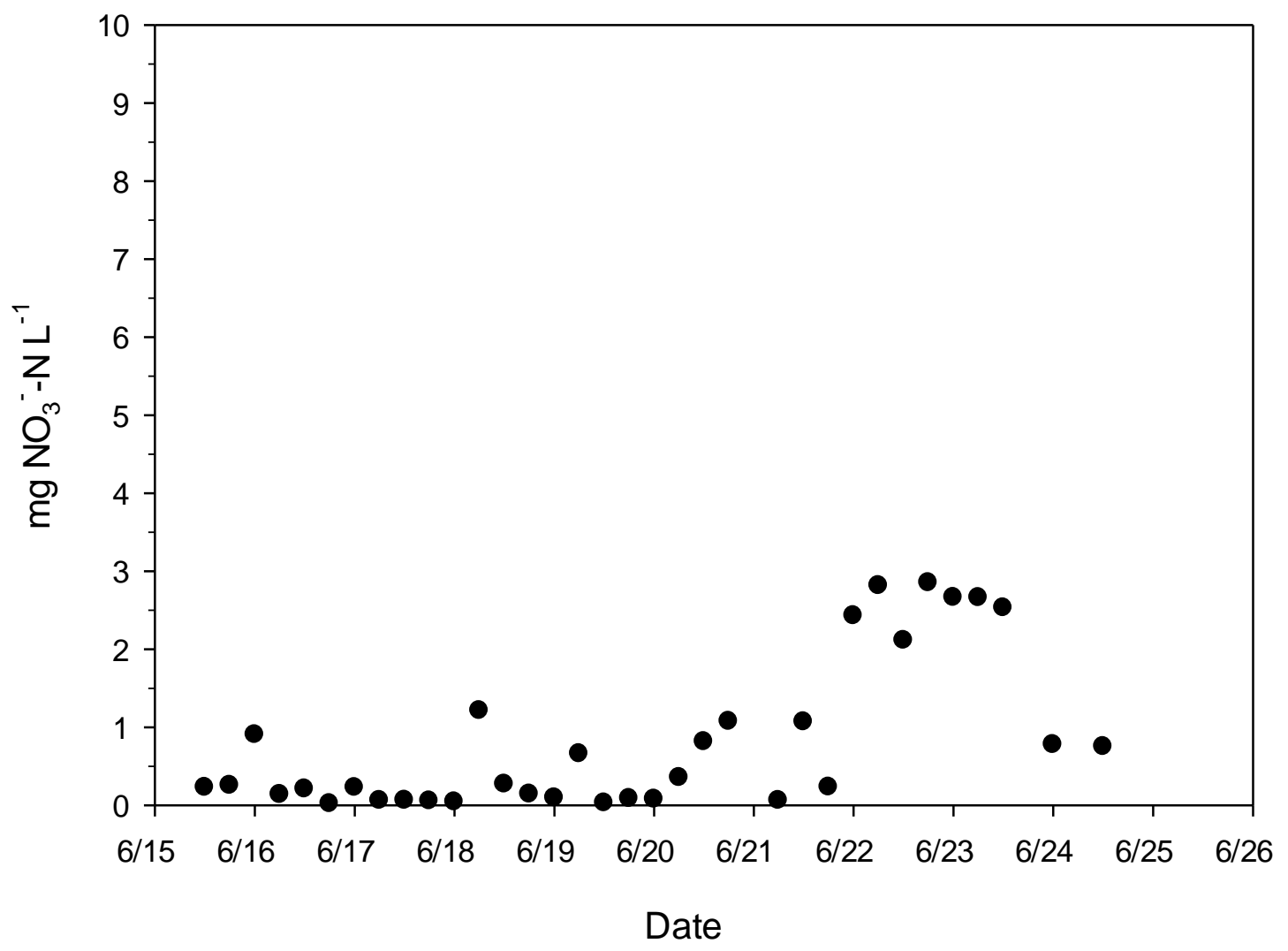

Appendix C. 7 SM5 $-\mathrm{NO}_{3}{ }^{-}$June 
Appendix C, Page 90

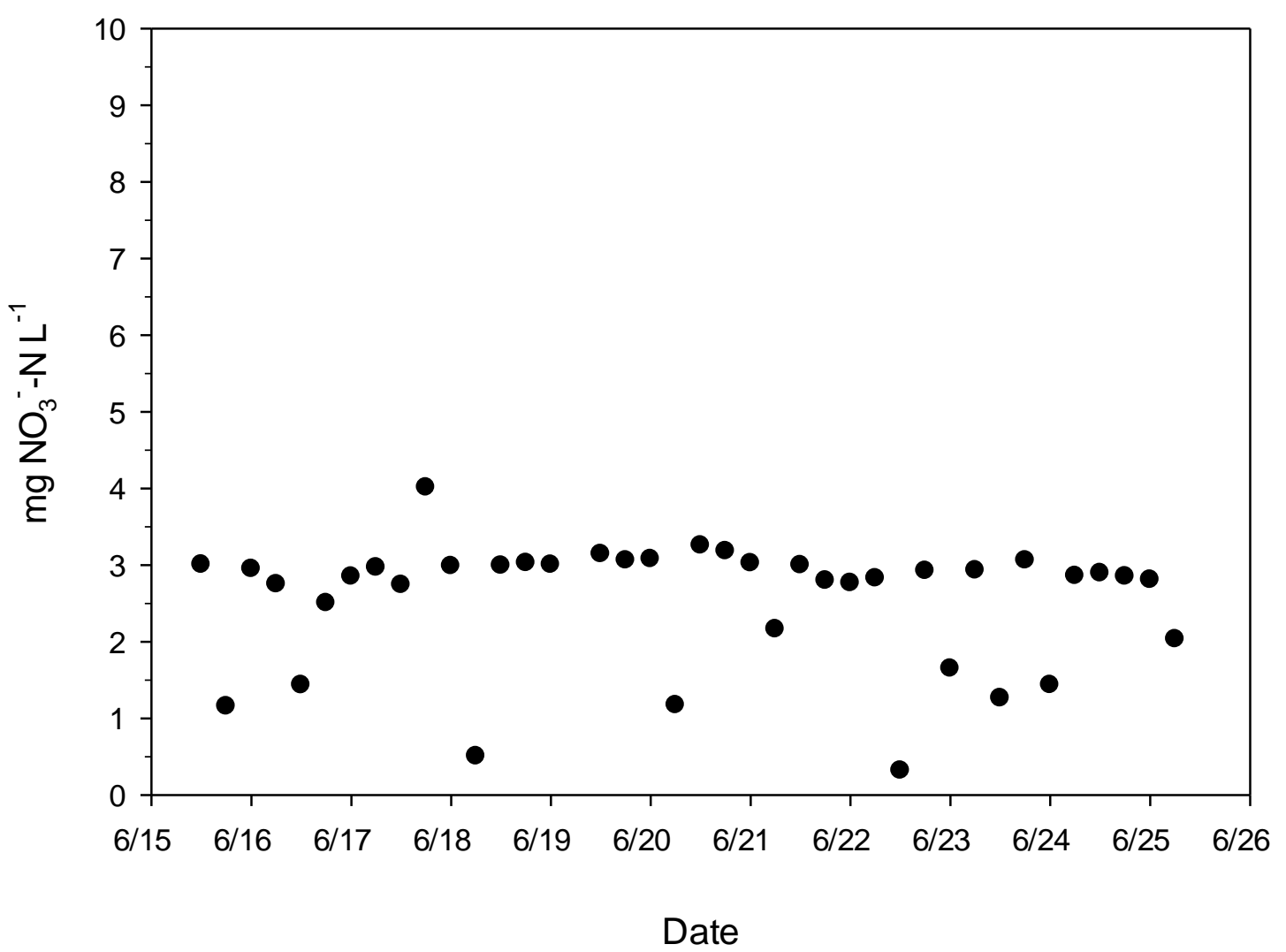

Appendix C. $8 \mathrm{SM} 5 \mathrm{a} \mathrm{NO}_{3}{ }^{-}$June 
Appendix C, Page 91

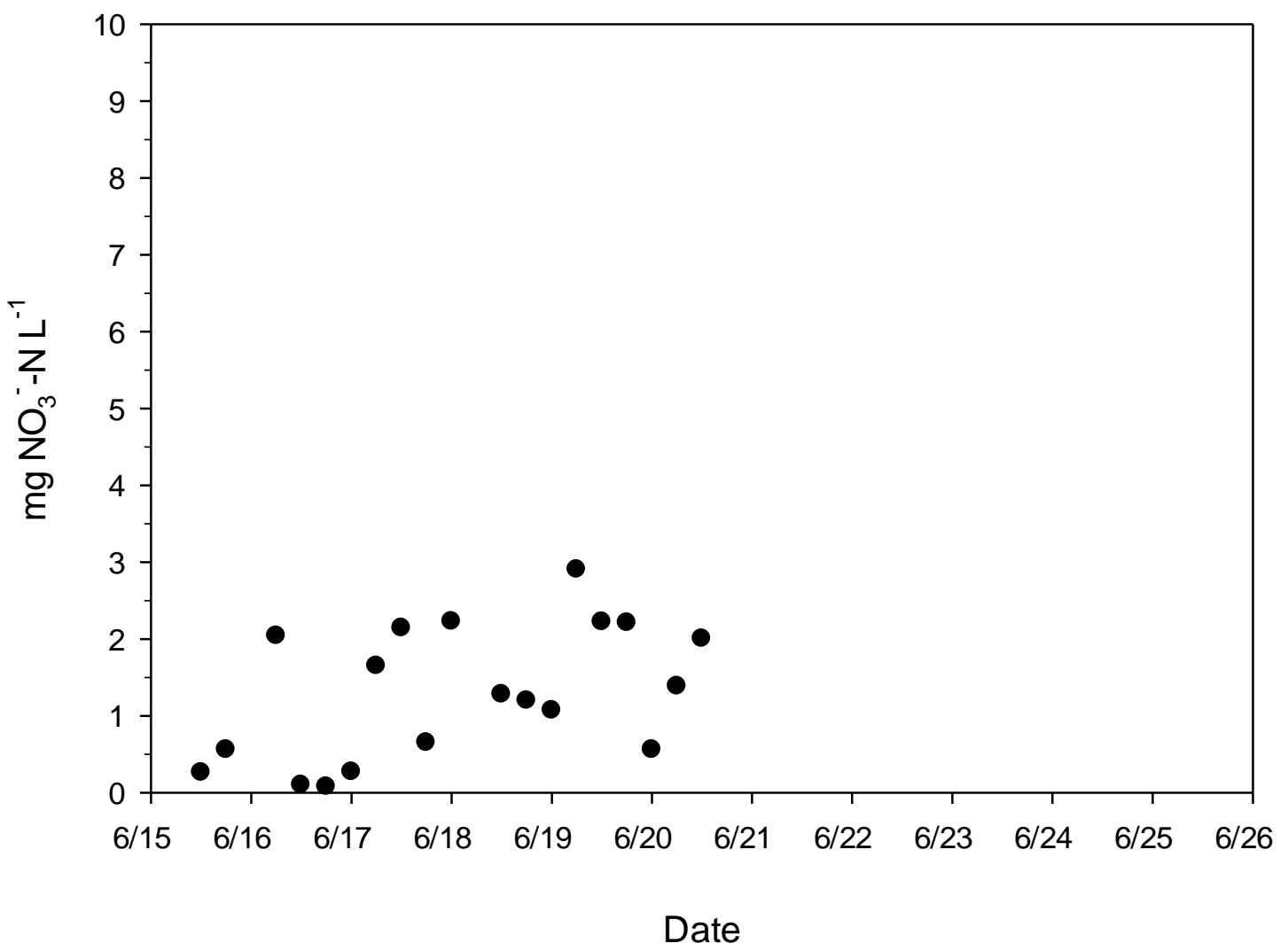

Appendix C. 9 SM 5b NO${ }_{3}^{-}$June 
Appendix C, Page 92

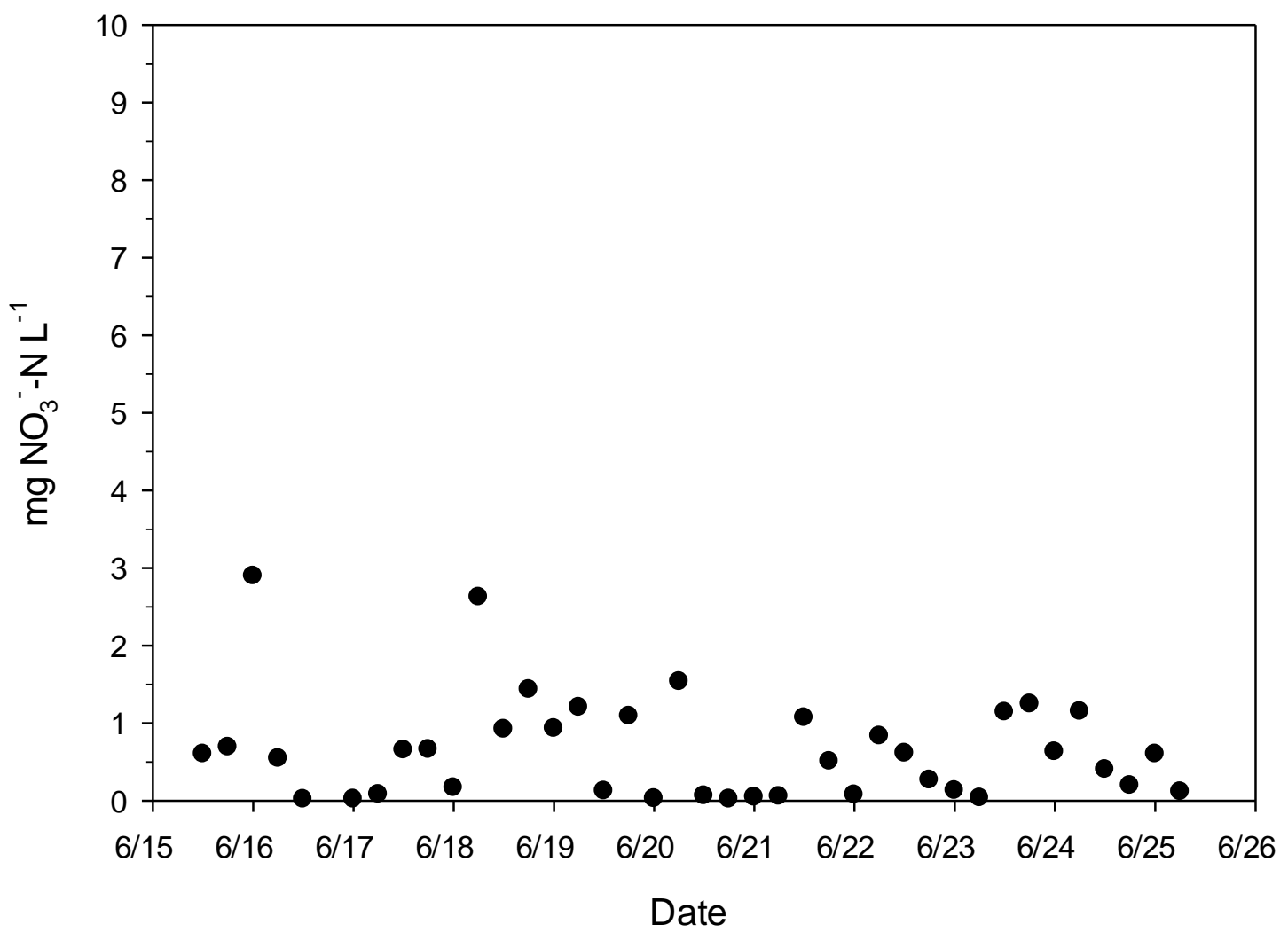

Appendix C. $10 \mathrm{SM}_{6} \mathrm{NO}_{3}{ }^{-}$June 
Appendix C, Page 93

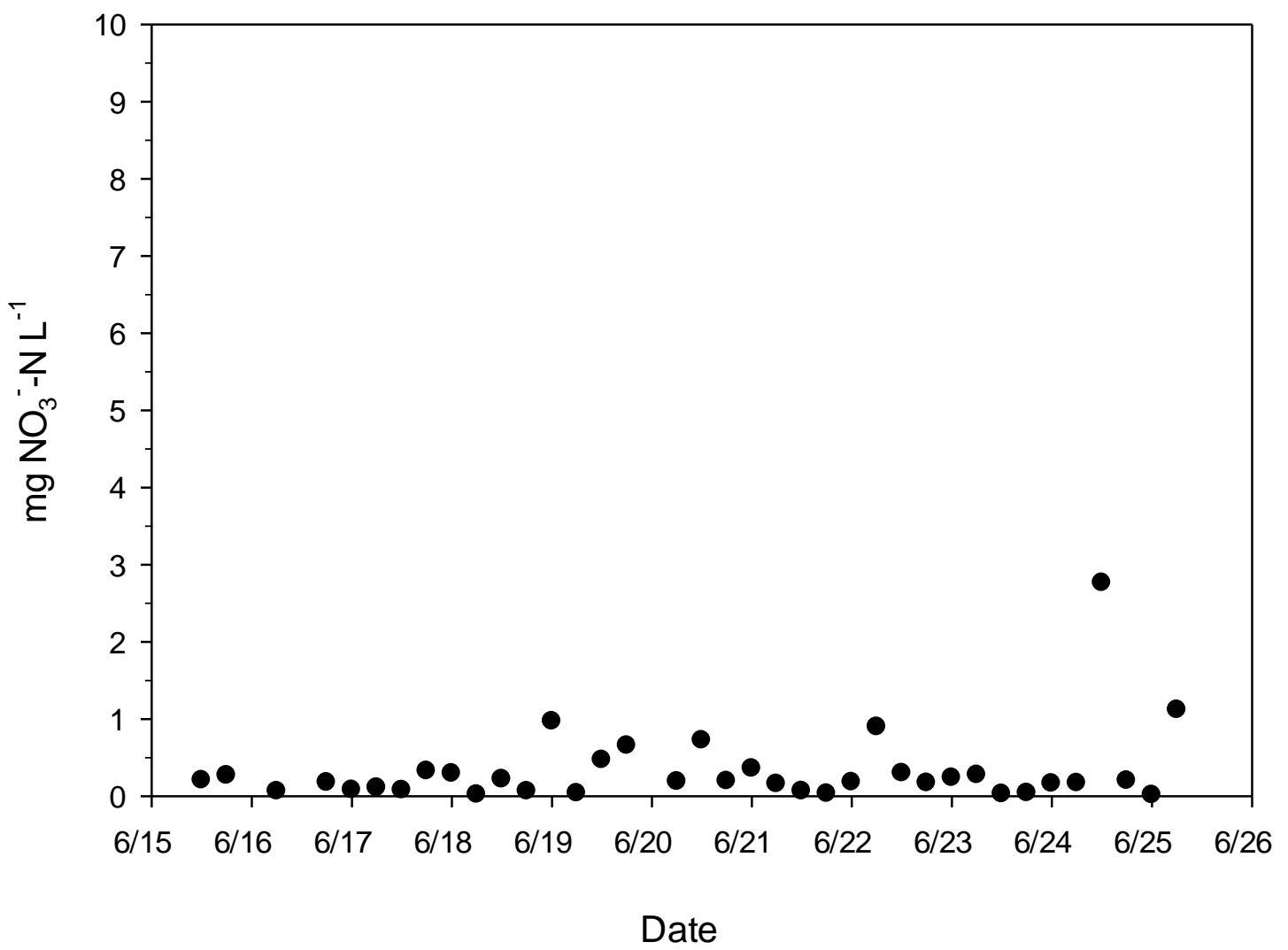

Appendix C. $11 \mathrm{SM} 7 \mathrm{NO}_{3}{ }^{-}$June 
Appendix C, Page 94

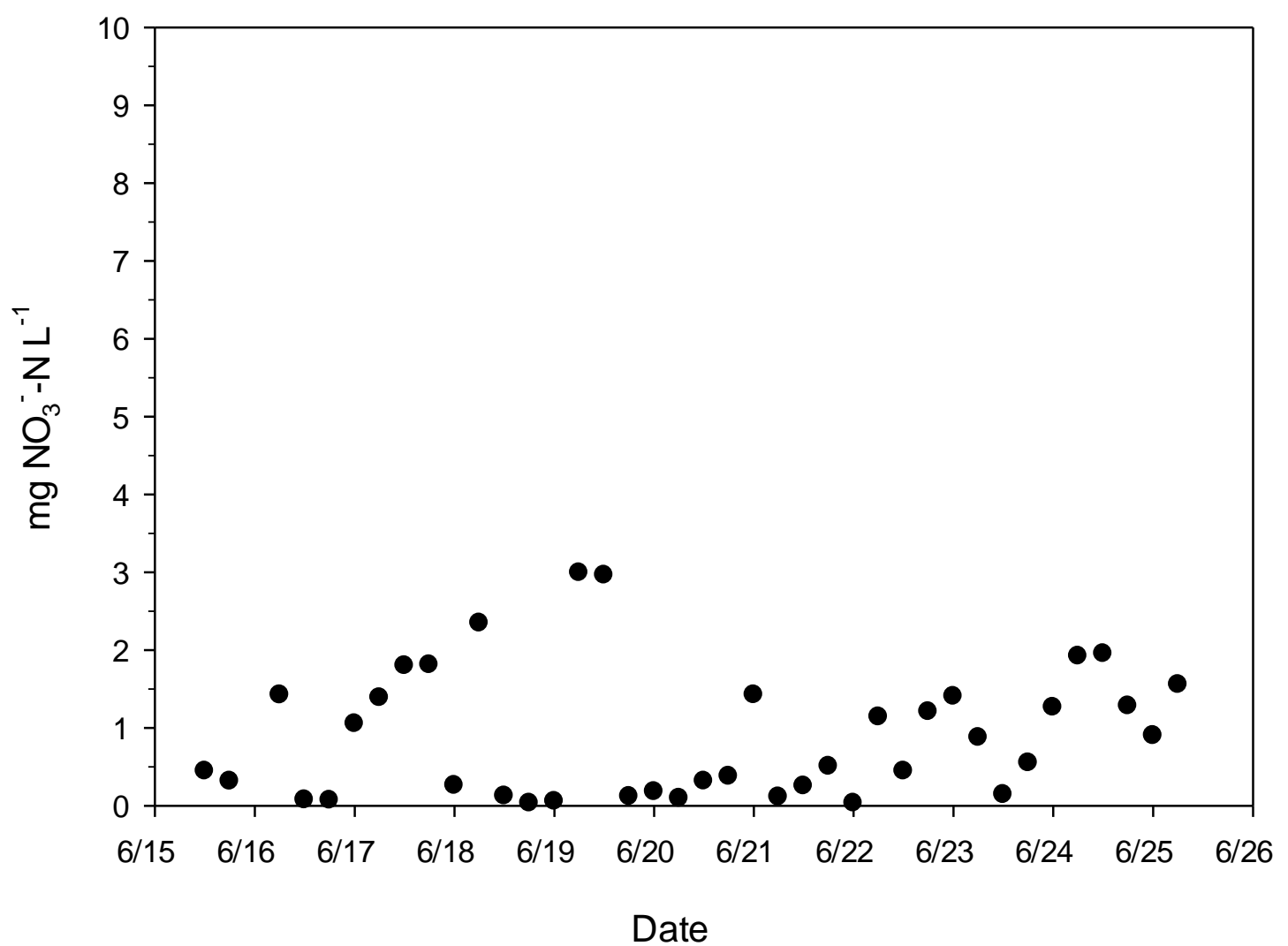

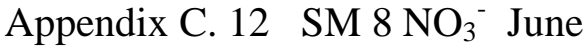


Appendix C, Page 95

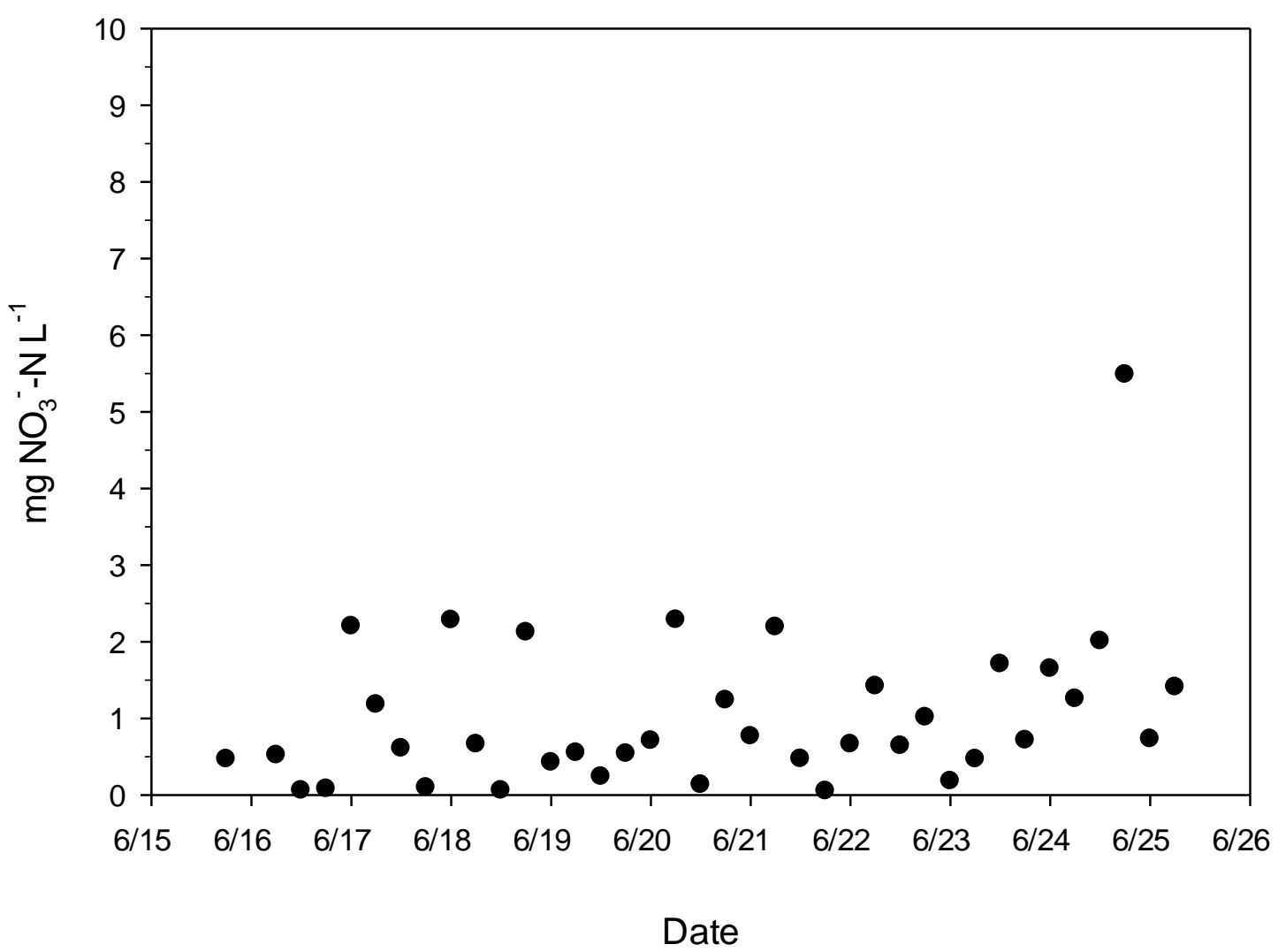

Appendix C. 13 SM 8a $\mathrm{NO}_{3}{ }^{-}$June 
Appendix C, Page 96

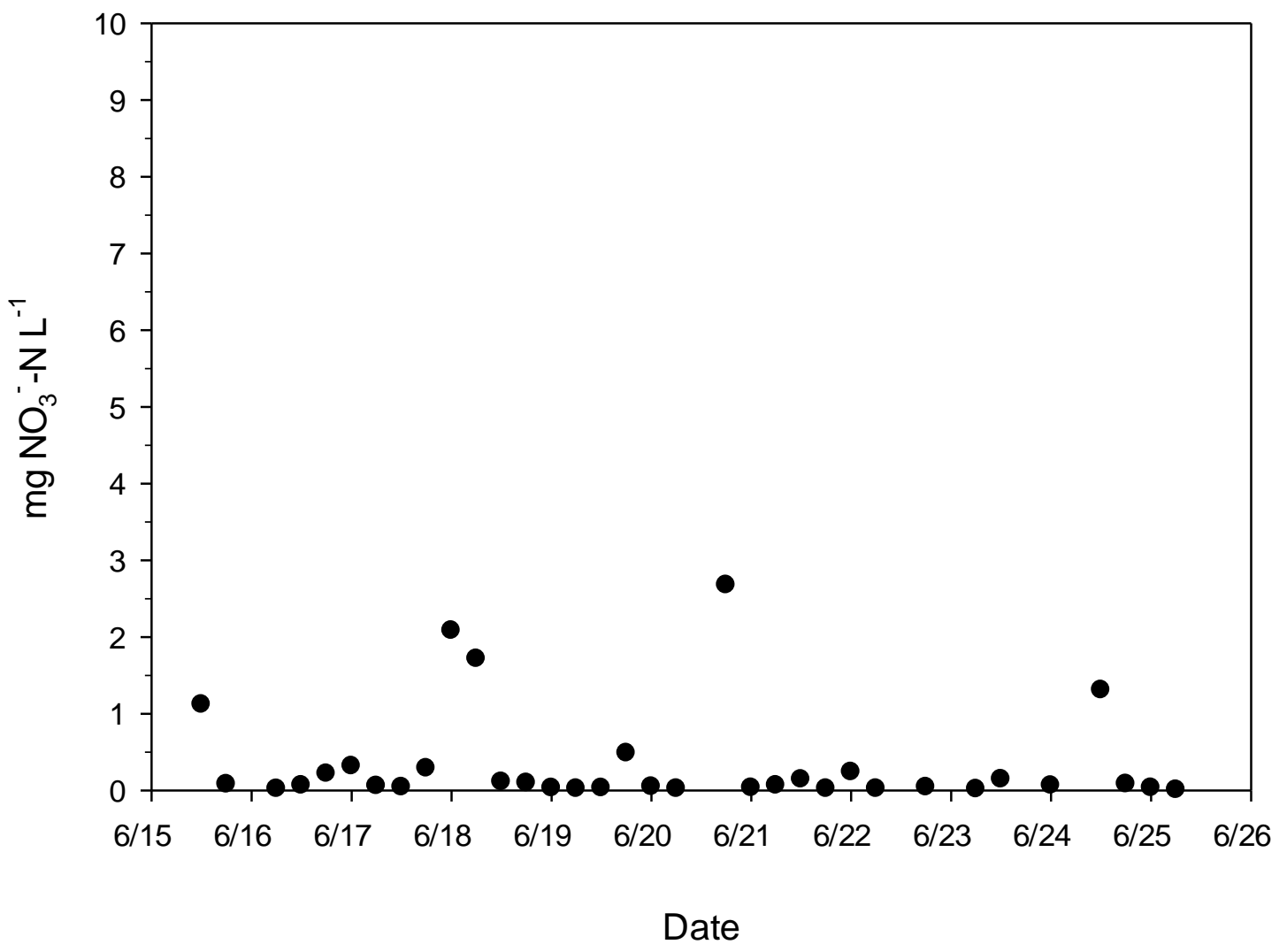

Appendix C. 14 SM 8b 
Appendix C, Page 97

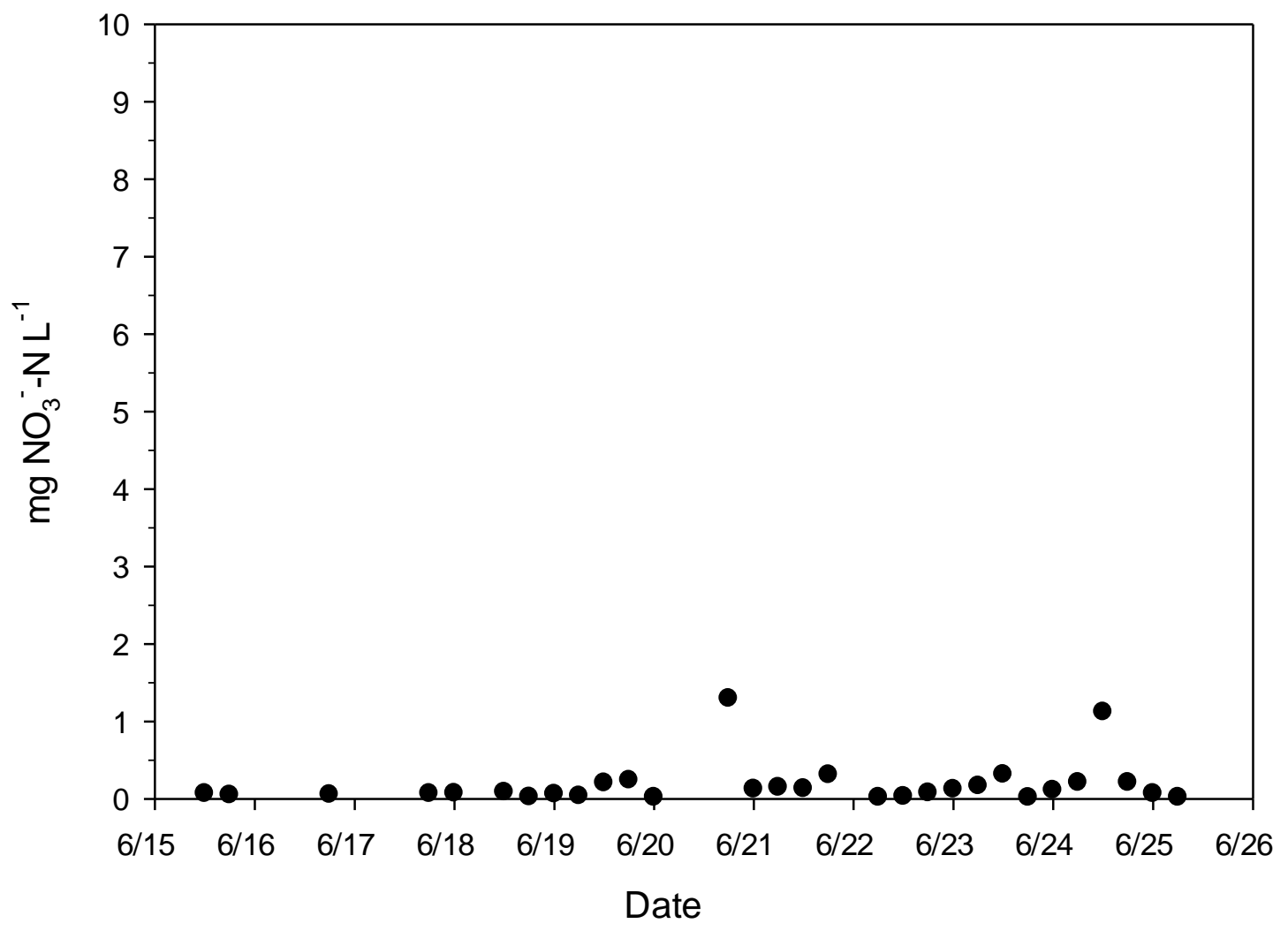

Appendix C. $15 \mathrm{SM}_{9} \mathrm{NO}_{3}{ }^{-}$June 
Appendix D, Page 98

4 Appendix D. Nitrate concentration in individual seepage meters, September, 2010 
Appendix D, Page 99

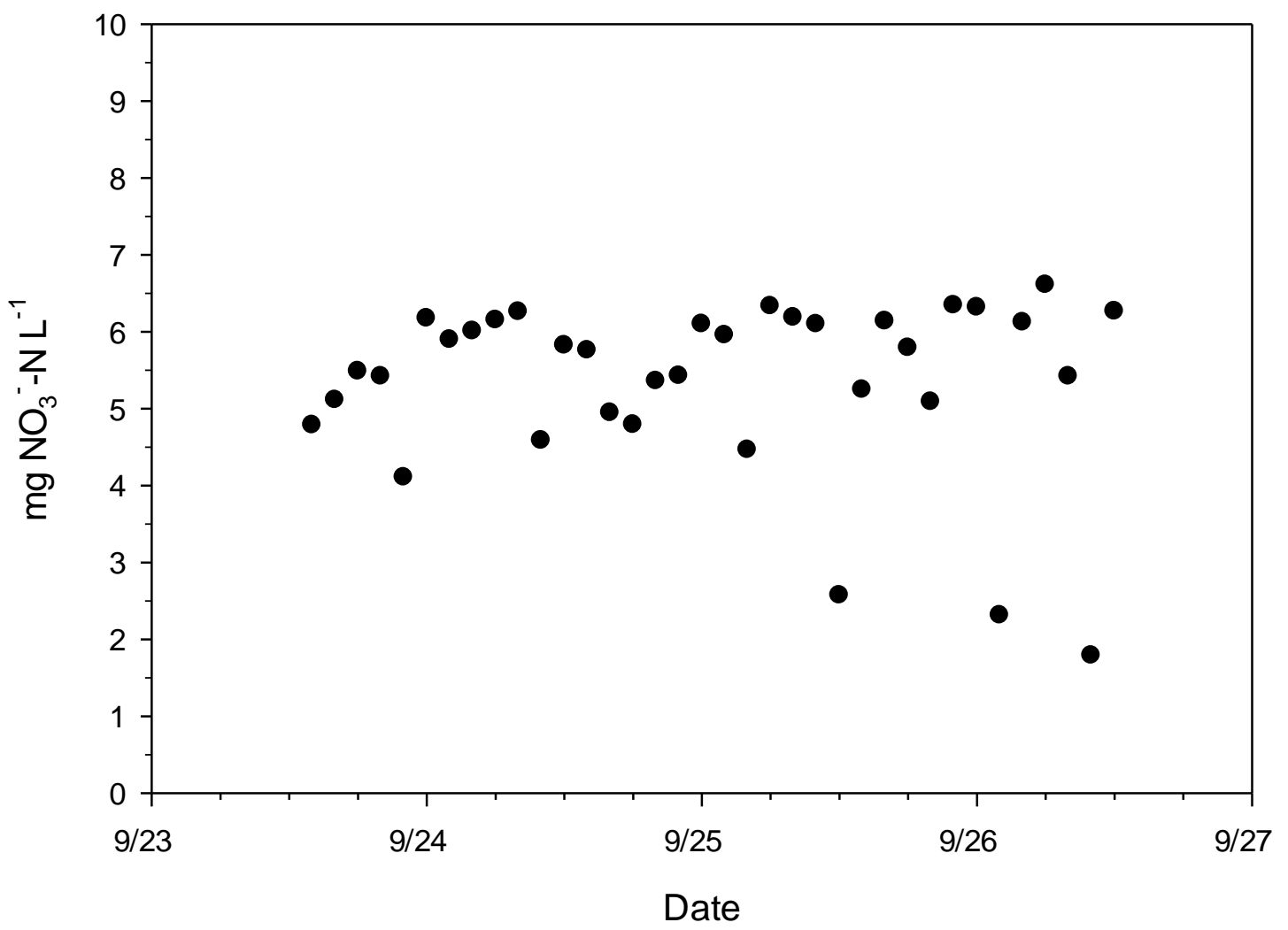

Appendix D. $1 \mathrm{SM} \mathrm{A} \mathrm{NO}_{3}^{-}$September 


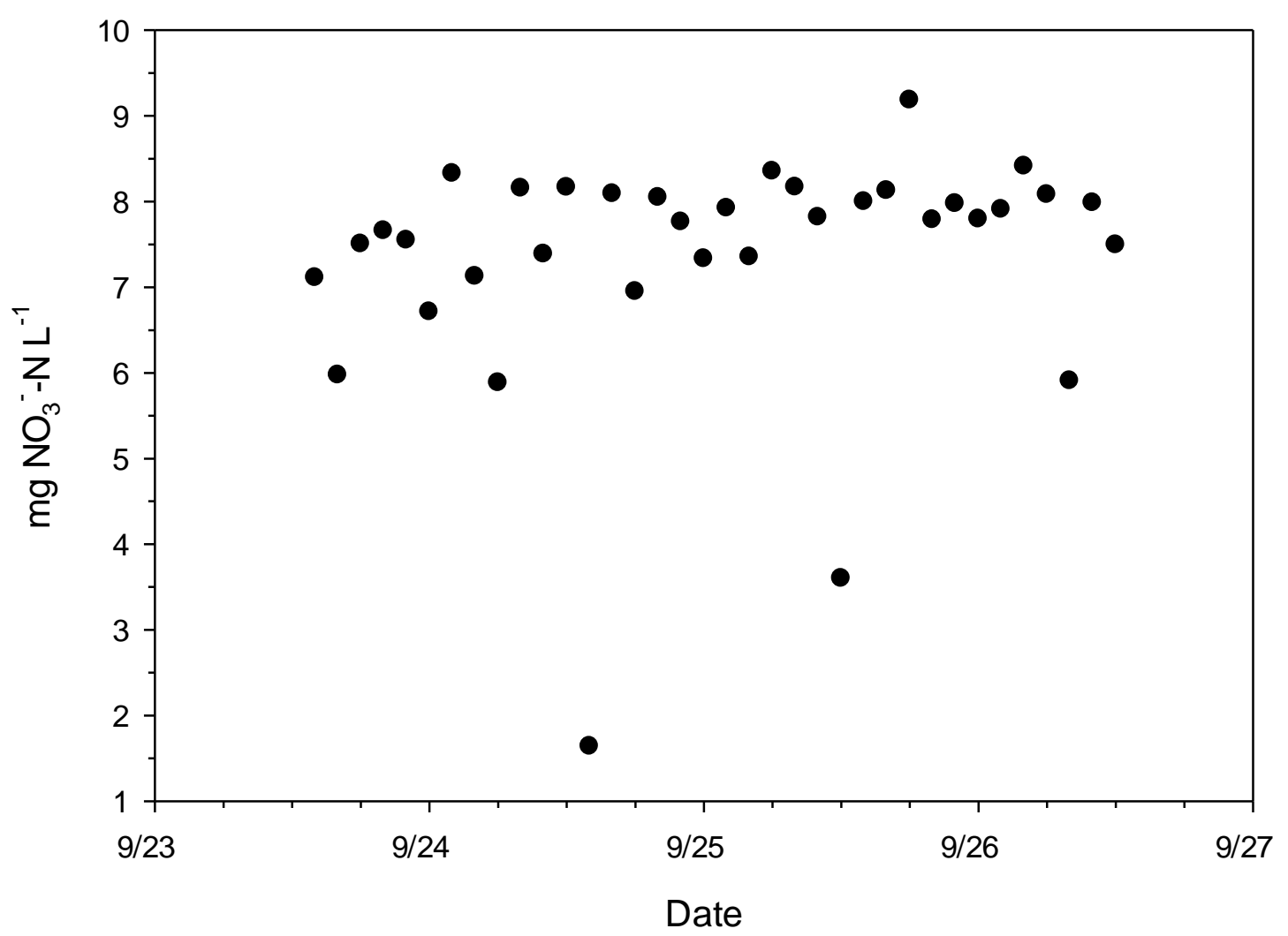

Appendix D. $2{\mathrm{SM} \mathrm{B} \mathrm{NO}_{3}}^{-}$September 
Appendix D, Page 101

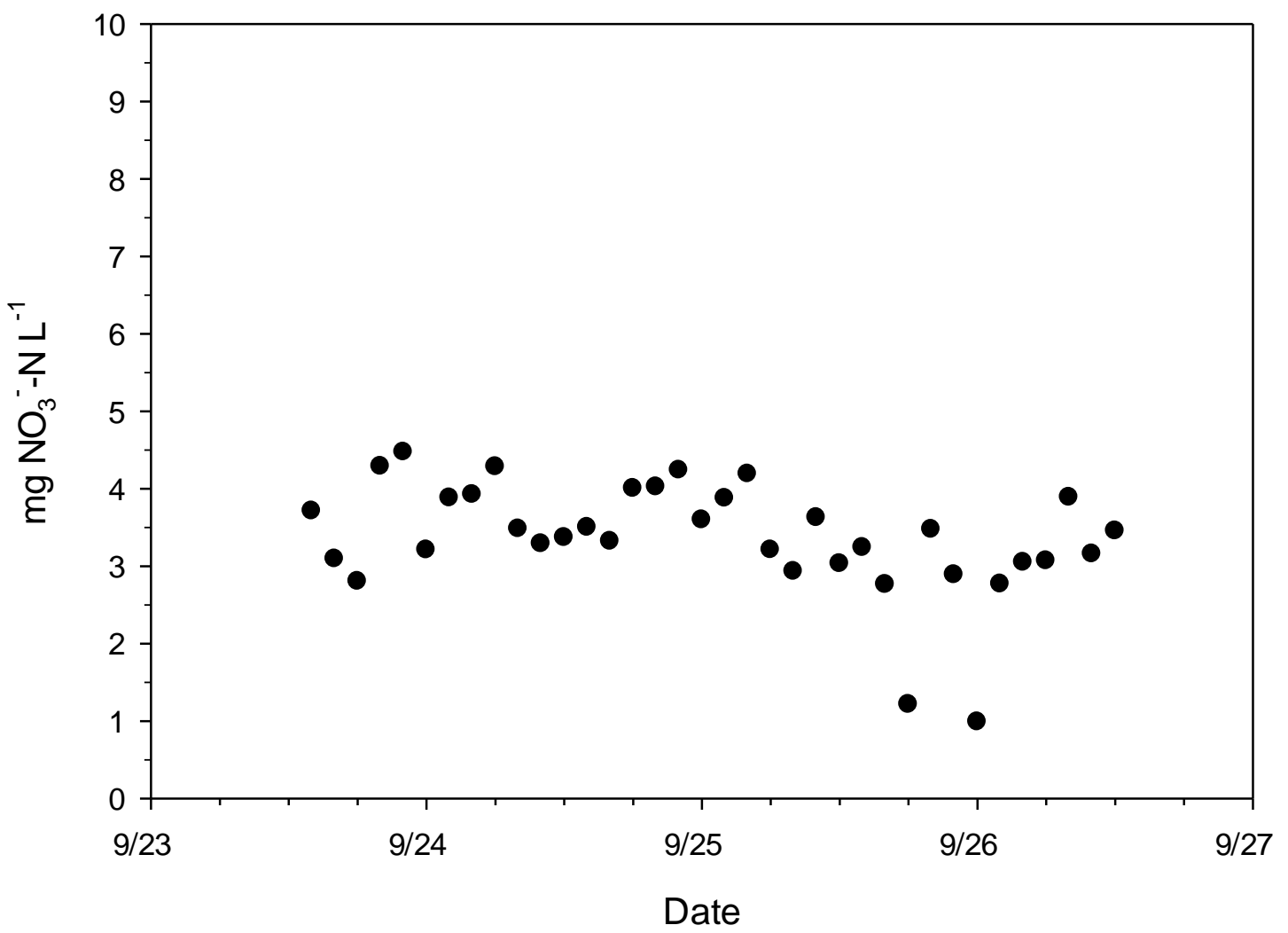

Appendix D. $3 \mathrm{SMC} \mathrm{NO}_{3}{ }^{-}$September 
Appendix D, Page 102

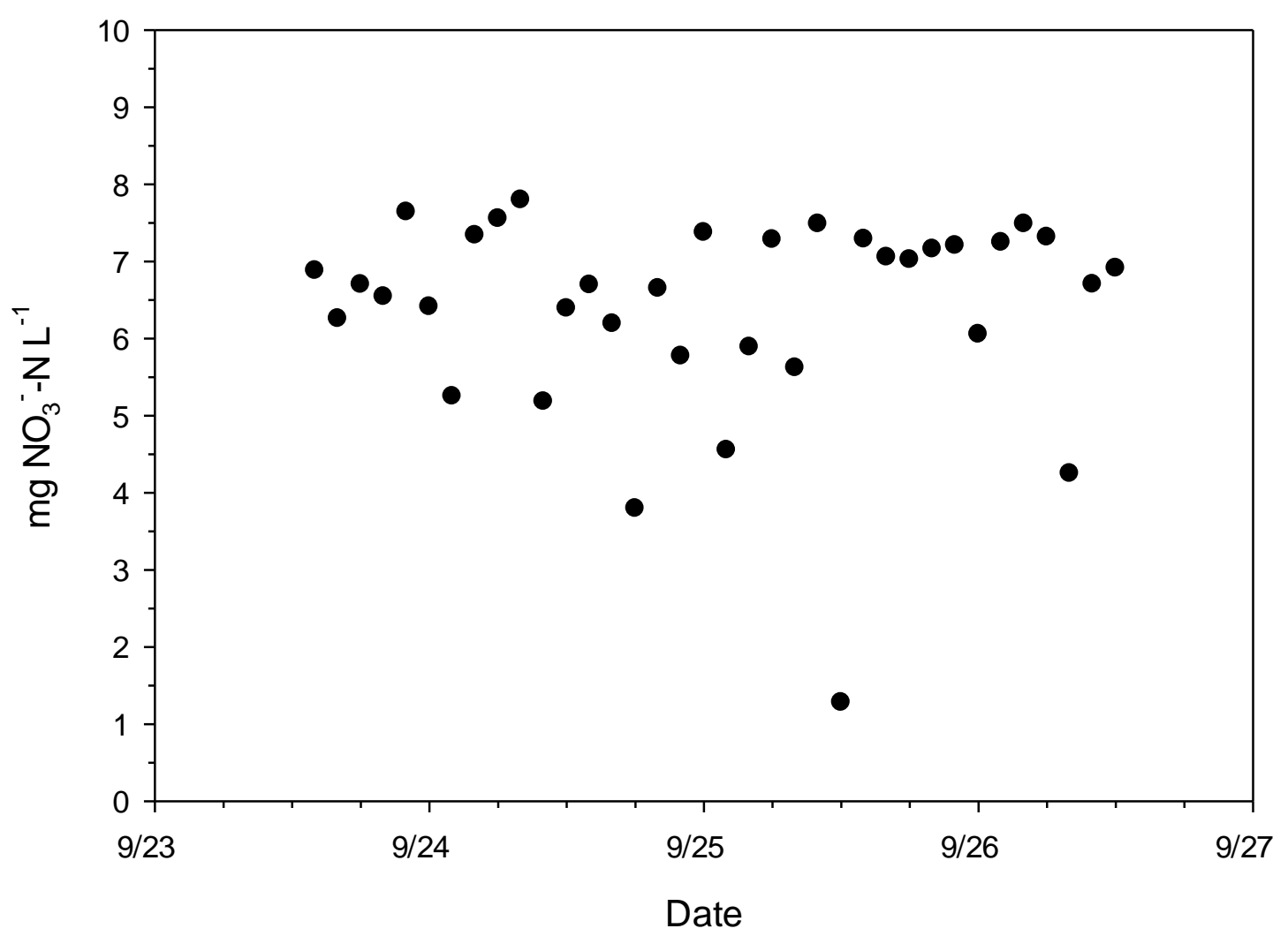

Appendix D. 4 SM D NO${ }_{3}^{-}$Sept 
Appendix D, Page 103

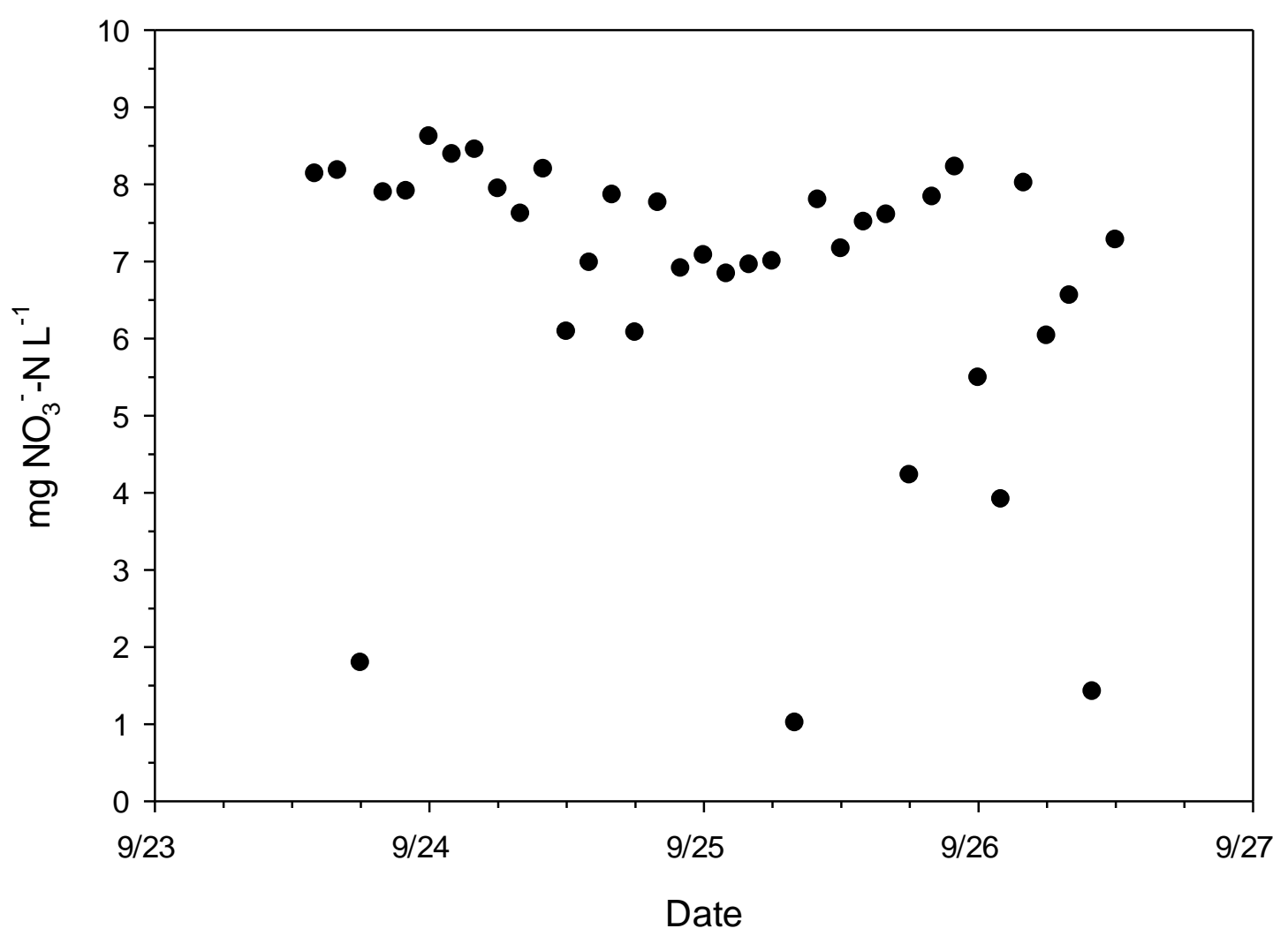

Appendix D. 5 SM E $\mathrm{NO}_{3}^{-}$September 
Appendix D, Page 104

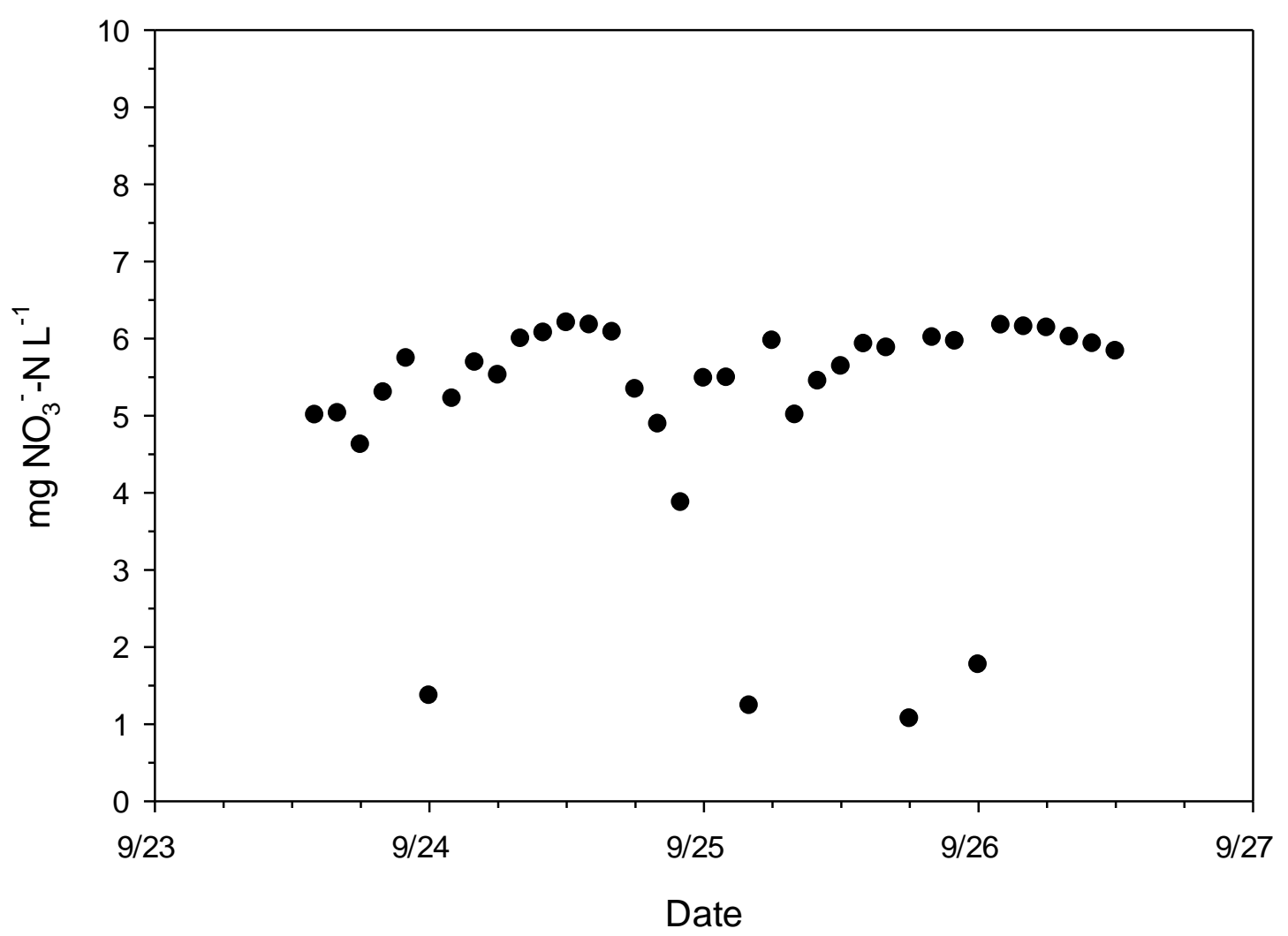

Appendix D. 6 SM F $\mathrm{NO}_{3}{ }^{-}$September 
5 Appendix E C-Q ( $\mathrm{NO}_{3}^{-}$concentration vs. discharge) plots for individual seepage meters over time in June 2010 
Appendix E, Page 106

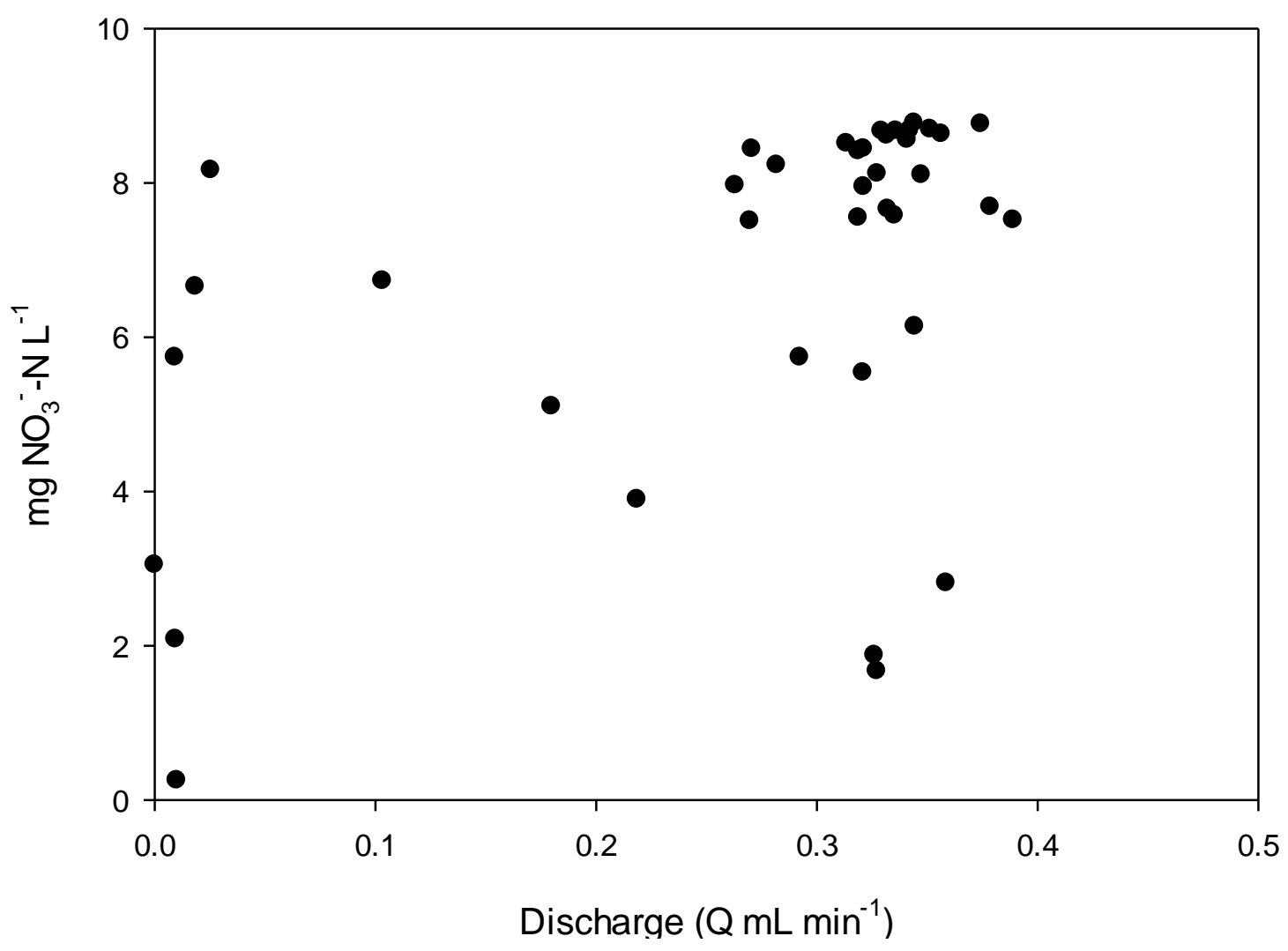

Appendix E. 1 SM 1 C vs. Q - June 
Appendix E, Page 107

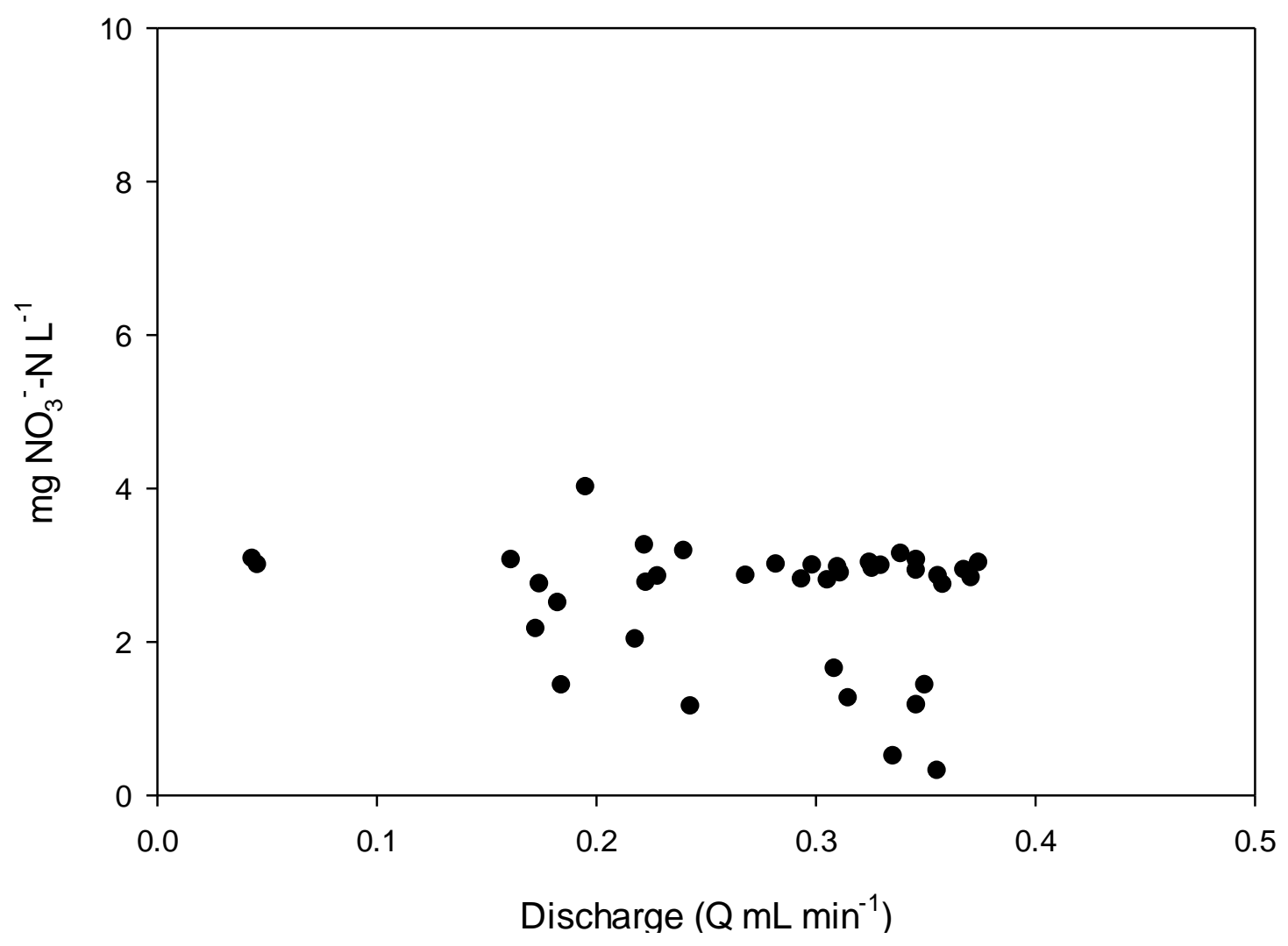

Appendix E. 2 SM 2 C vs. Q - June 
Appendix E, Page 108

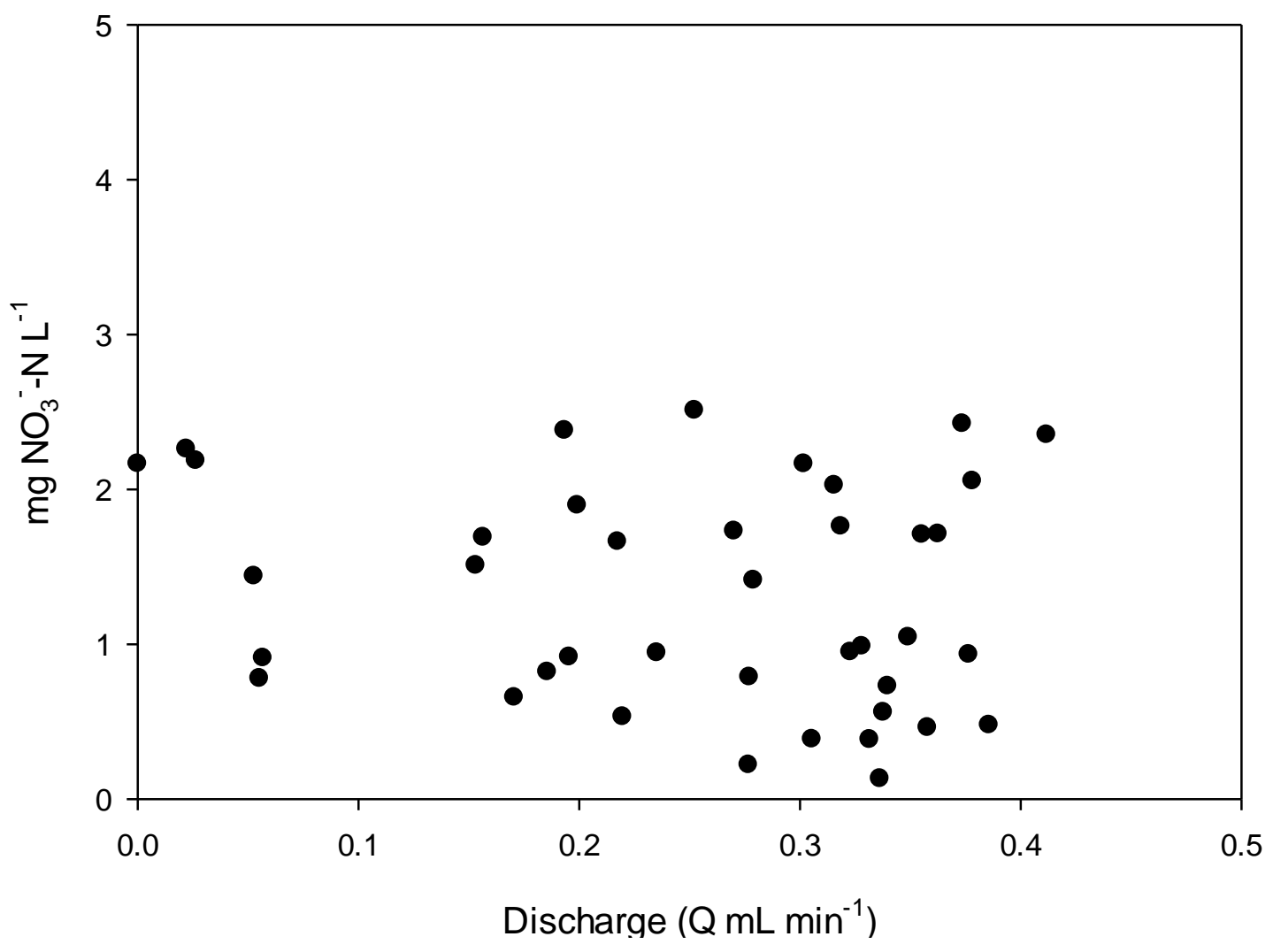

Appendix E. 3 SM 2A C vs. Q - June 


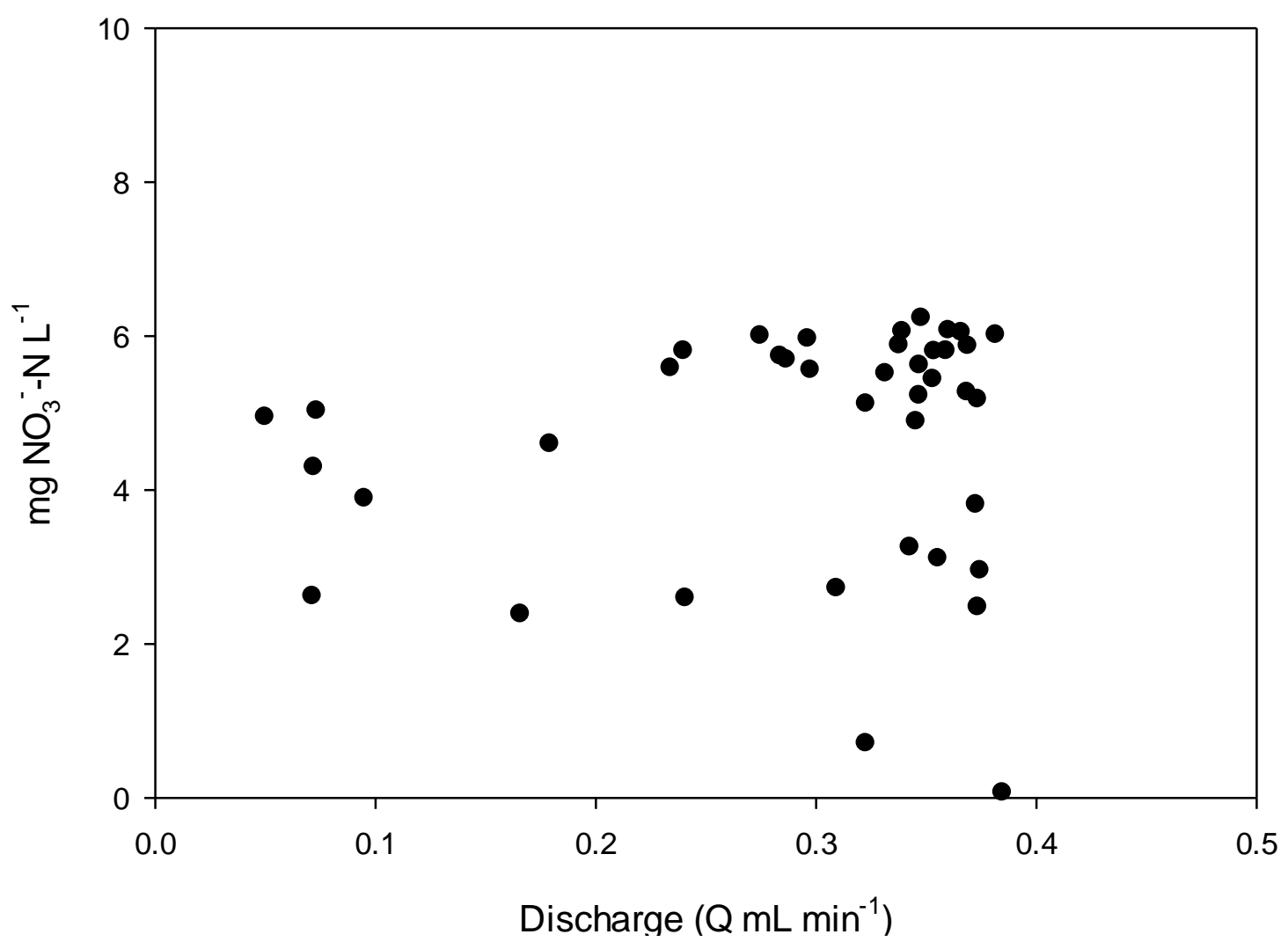

Appendix E. 4 SM 2B C vs. Q - June 


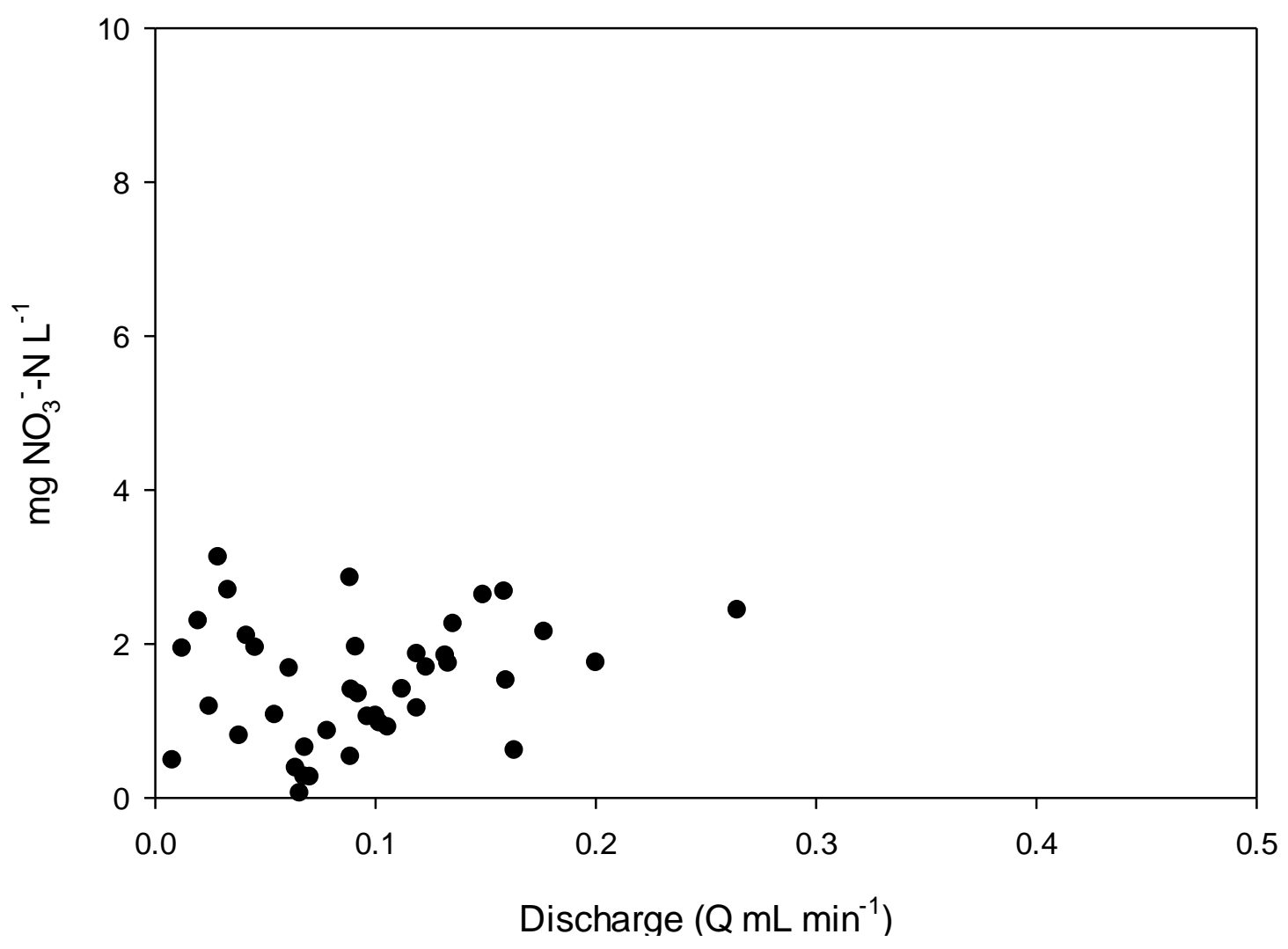

Appendix E. 5 SM 3 C vs. Q - June 


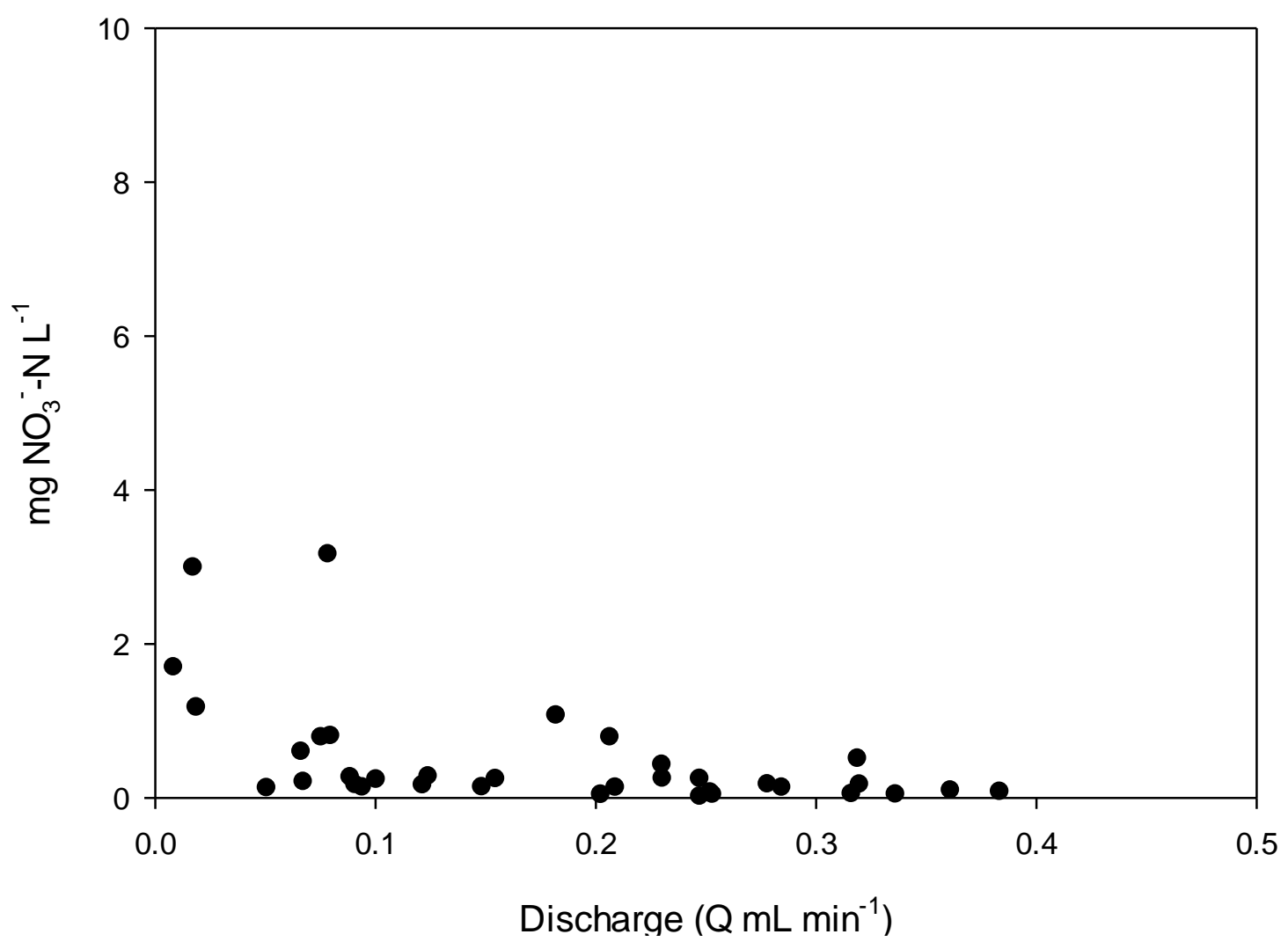

Appendix E. 6 SM 4 C vs. Q - June 
Appendix E, Page 112

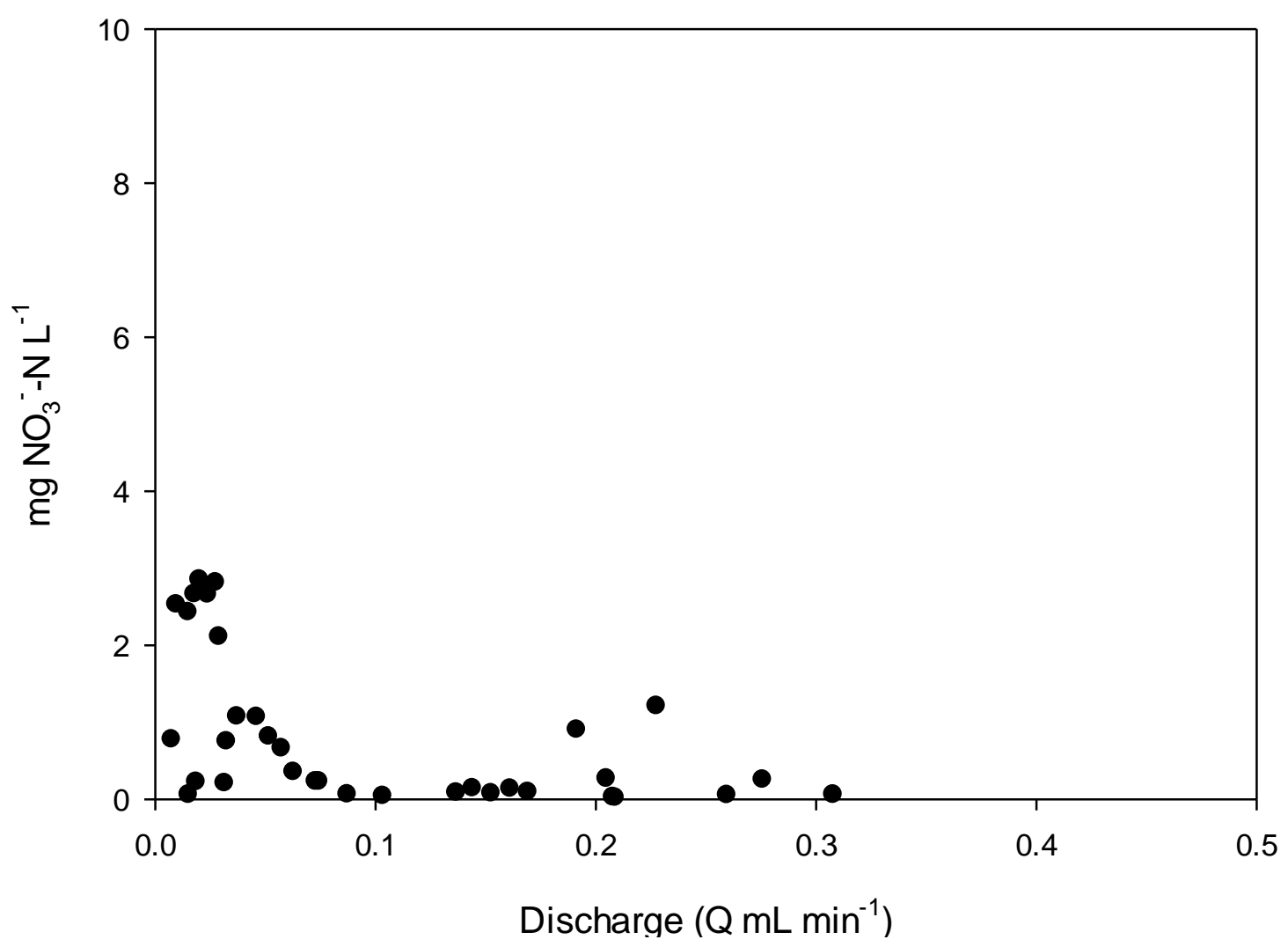

Appendix E.7 SM5 C vs. Q - June 
Appendix E, Page 113

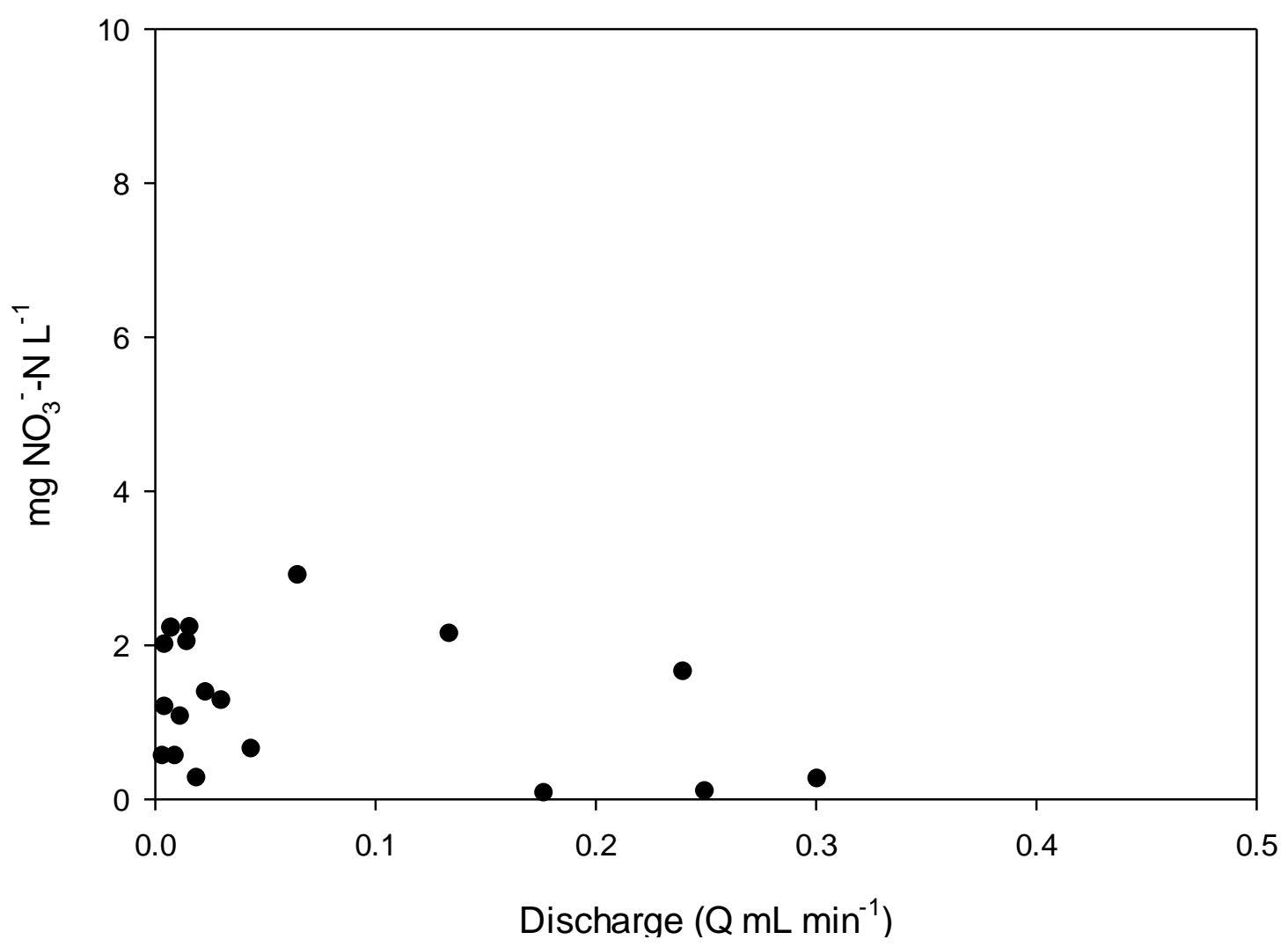

Appendix E.8 SM5a C vs. Q - June 
Appendix E, Page 114

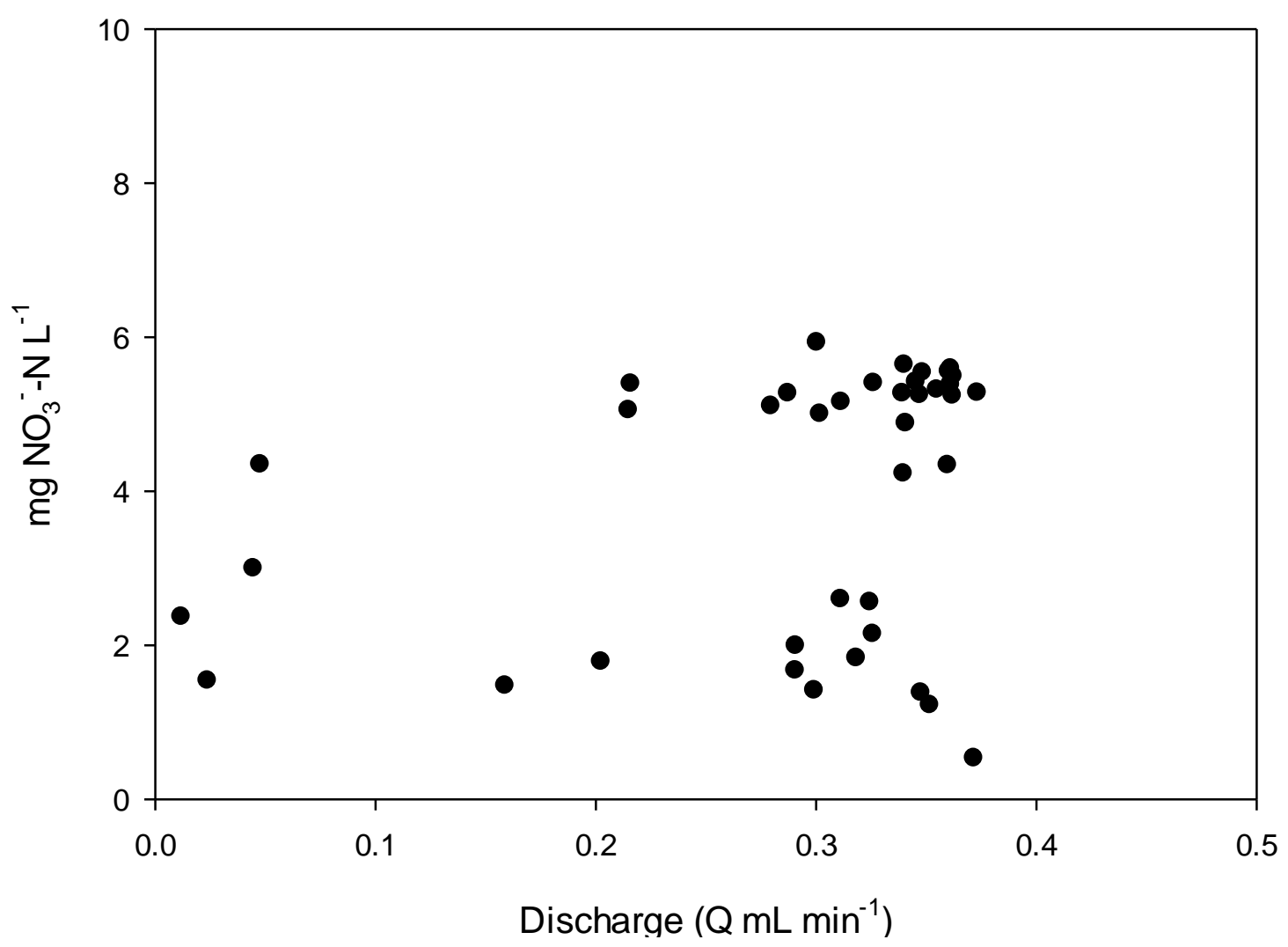

Appendix E.9 SM5b C vs. Q- June 
Appendix E, Page 115

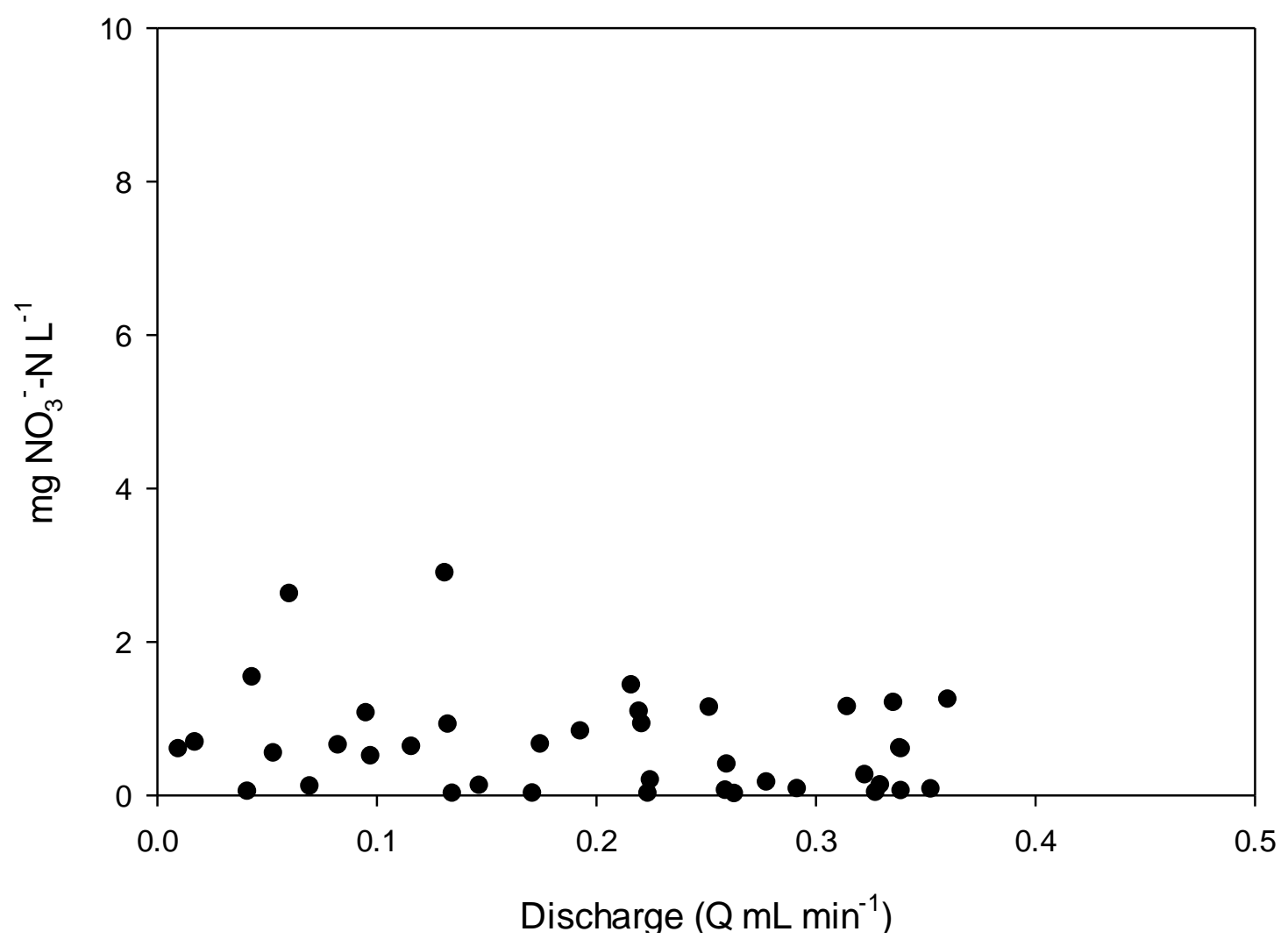

Appendix E.10 SM6 C vs. Q - June 
Appendix E, Page 116

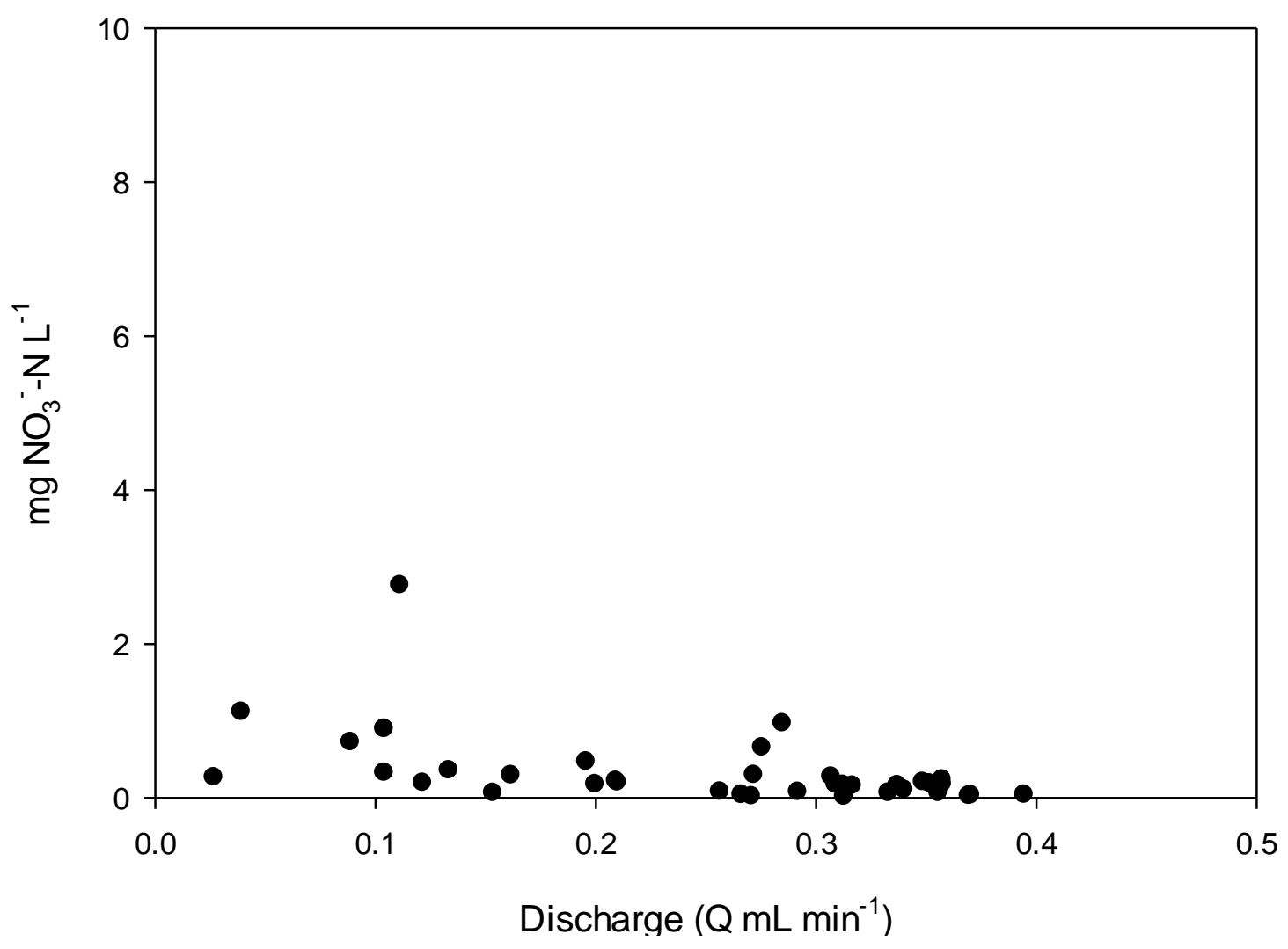

Appendix E.11 SM7 C vs. Q - June 


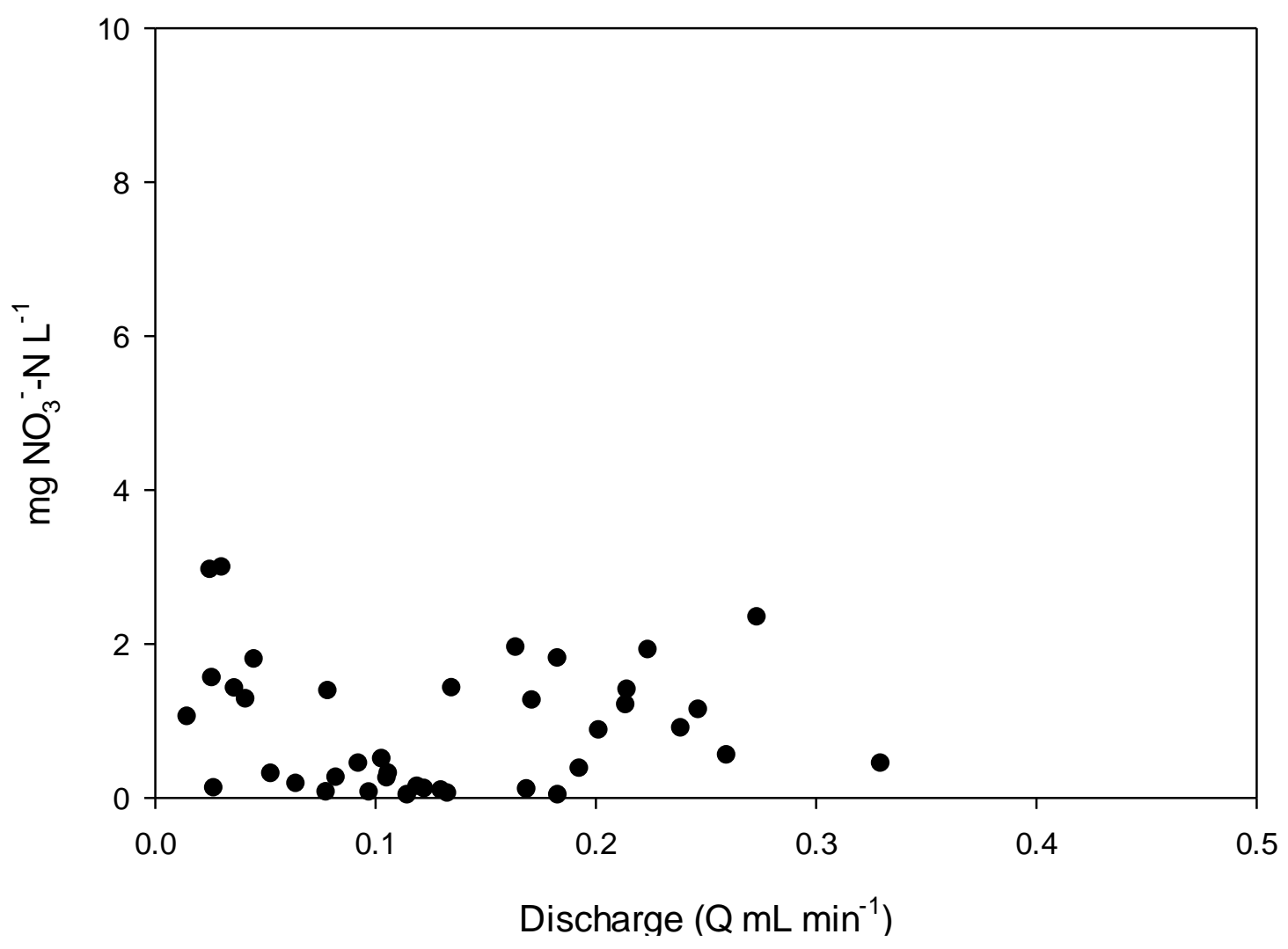

Appendix E.12 SM8 C vs. Q-June 


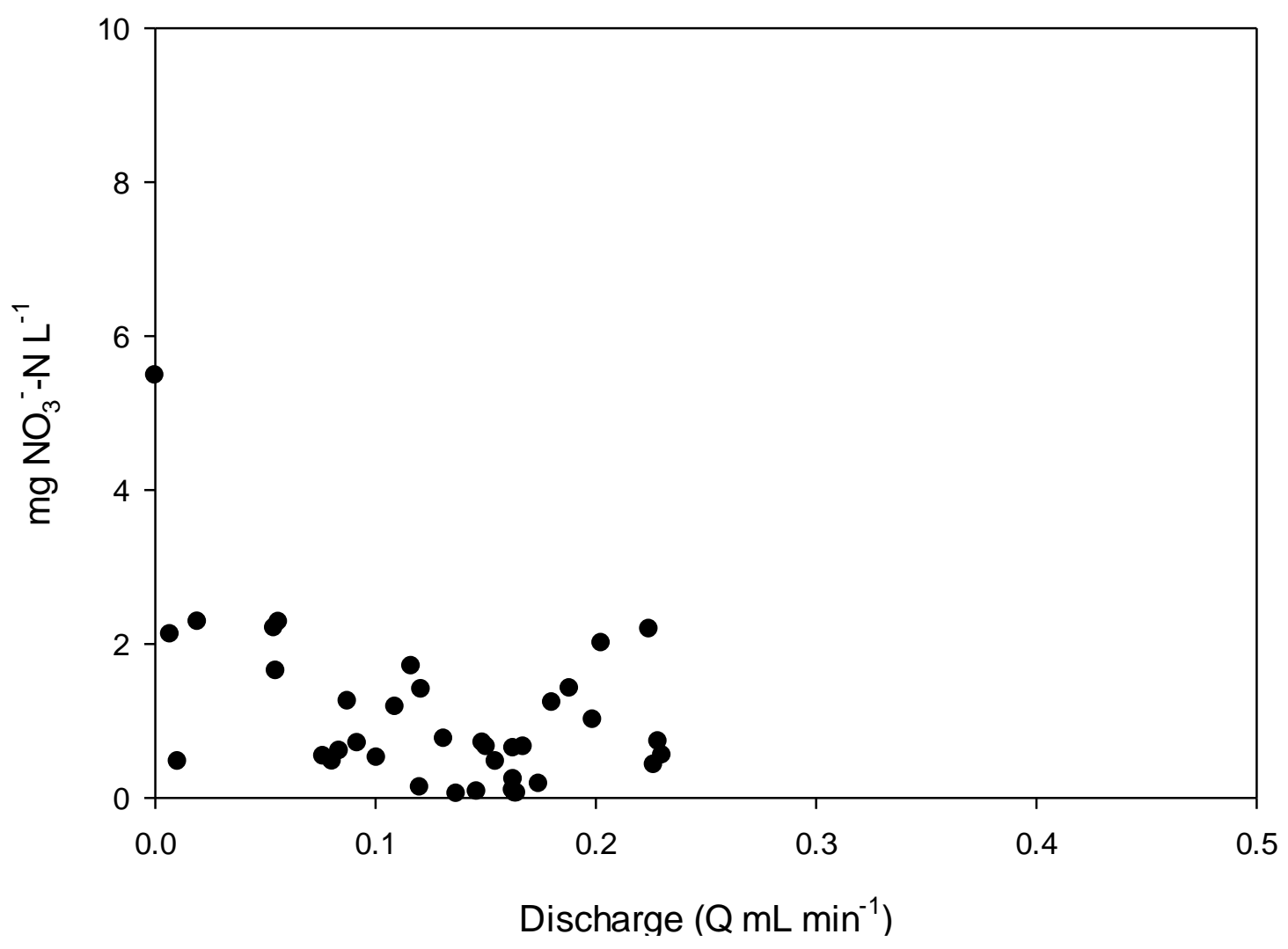

Appendix E.13 SM8a C vs. Q - June 
Appendix E, Page 119

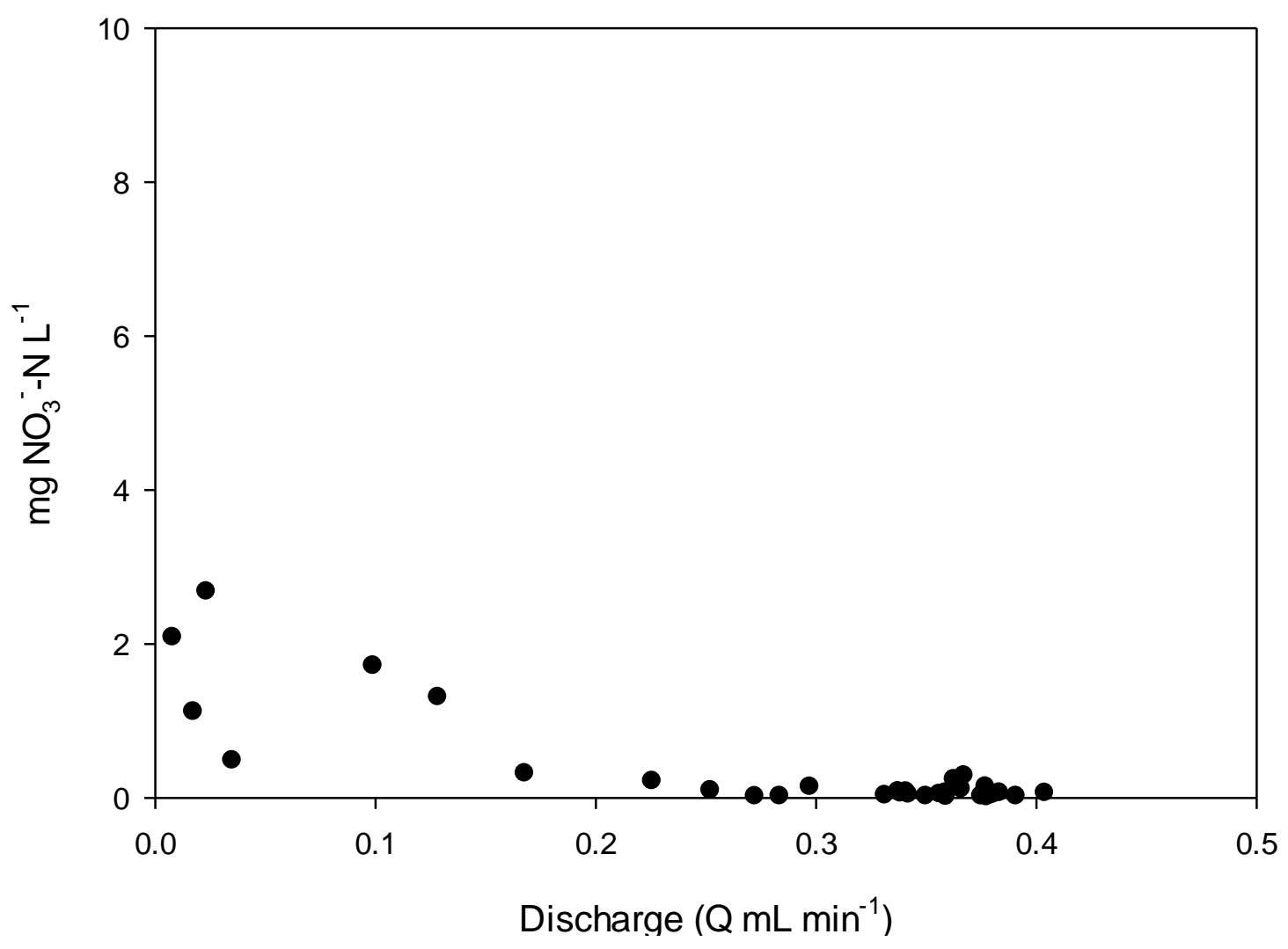

Appendix E.14 SM8b C vs. Q - June 
Appendix E, Page 120

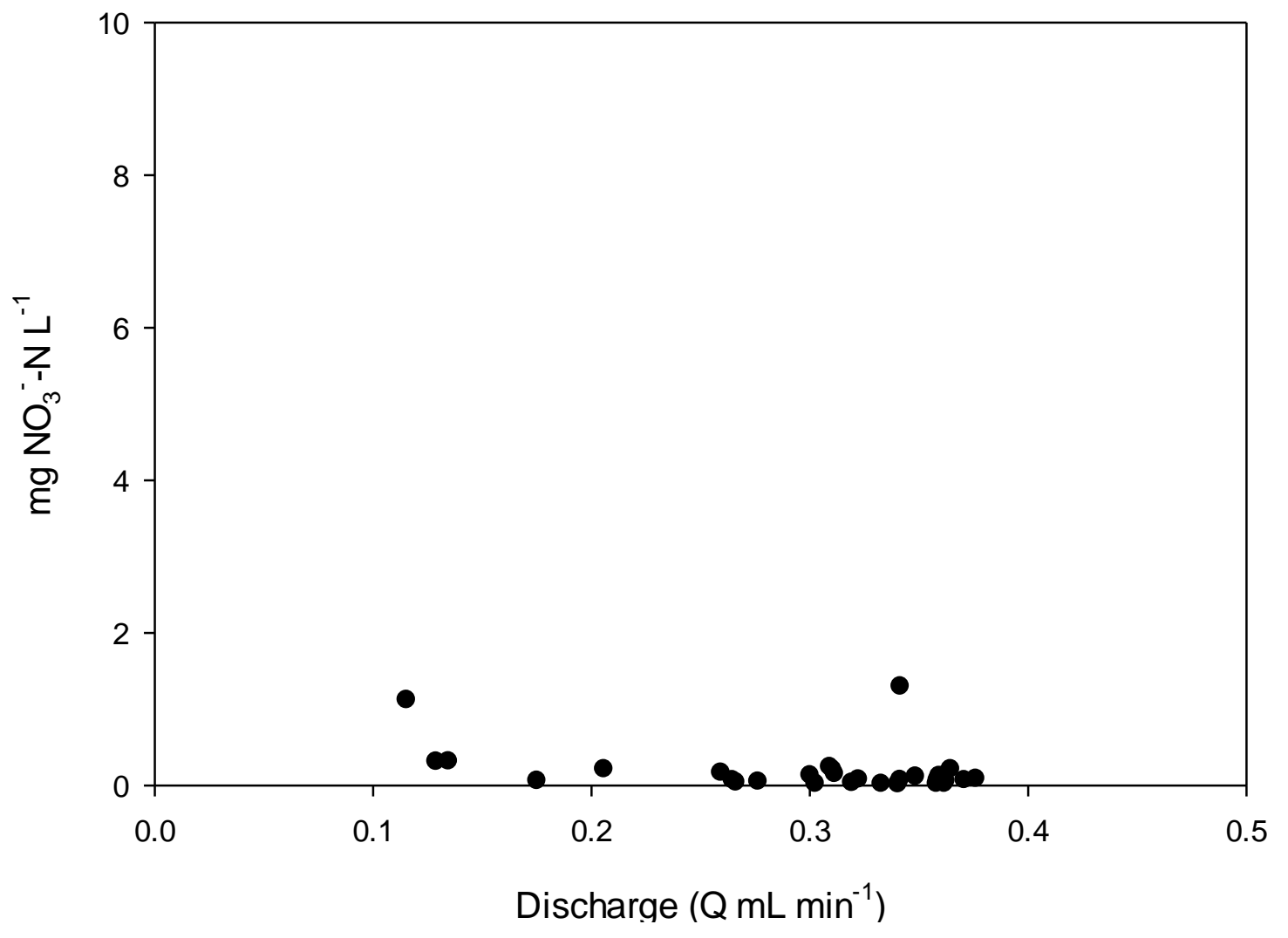

Appendix E.15 SM9 C vs. Q-June 


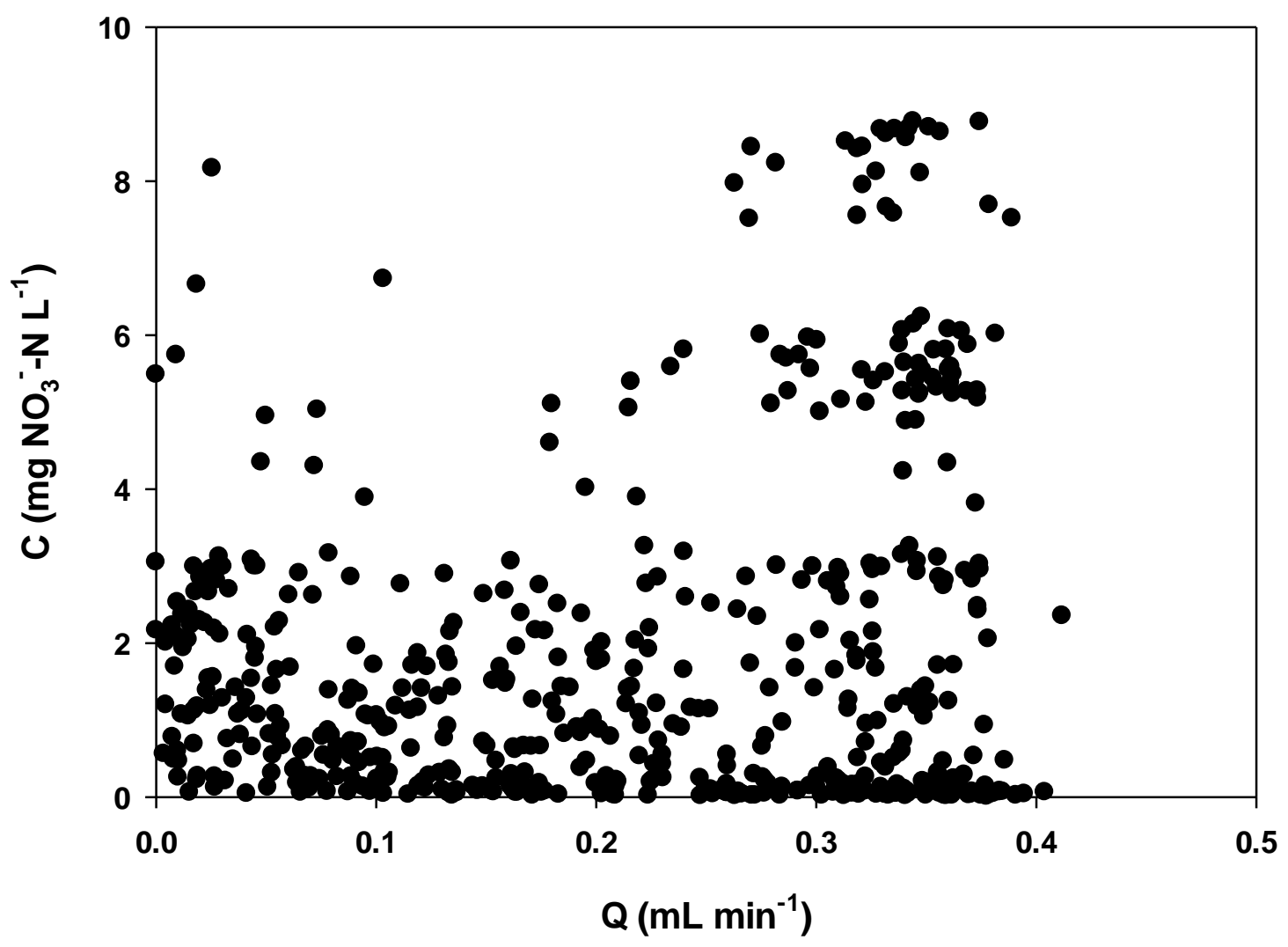

Appendix E. 16 Composite C vs Q plot for all June 2010 seepage meters. 
Appendix F, Page 122

6 Appendix F CQ (concentration vs.discharge) plots for individual seepage meters in September, 2010 
Appendix F, Page 123

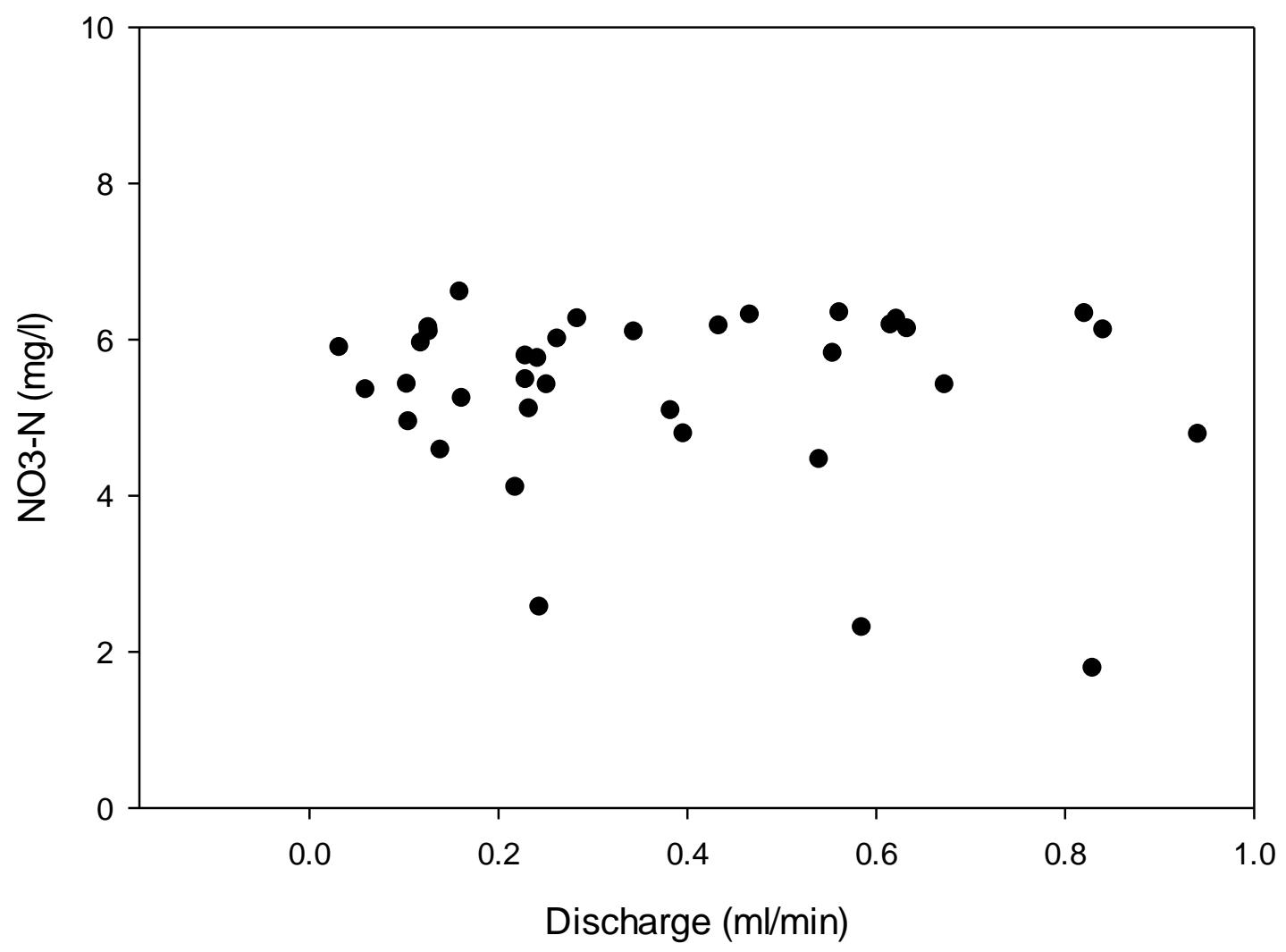

Appendix F.1 - SMA - September 
Appendix F, Page 124

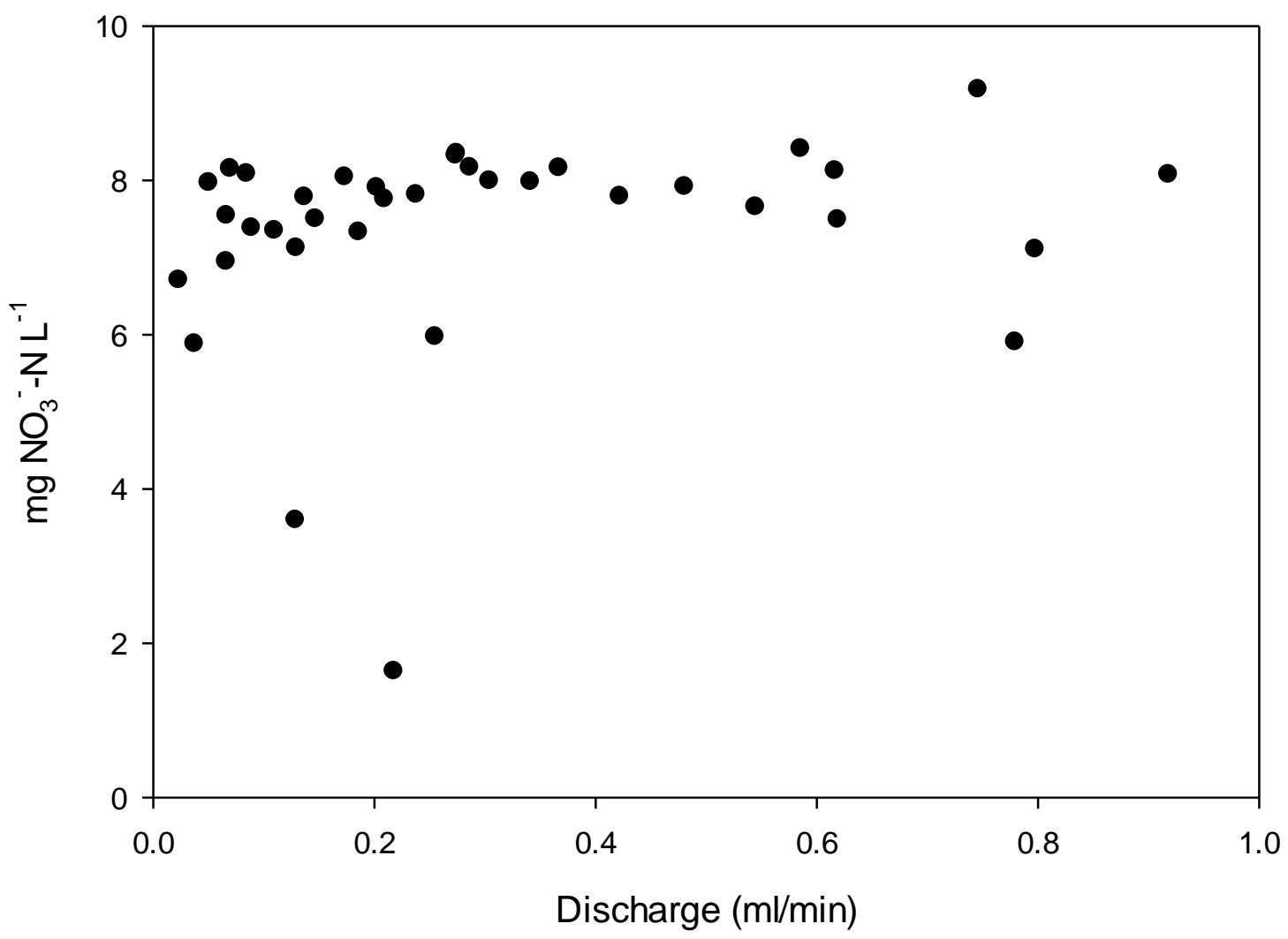

Appendix F.2 - SMB - September 
Appendix F, Page 125

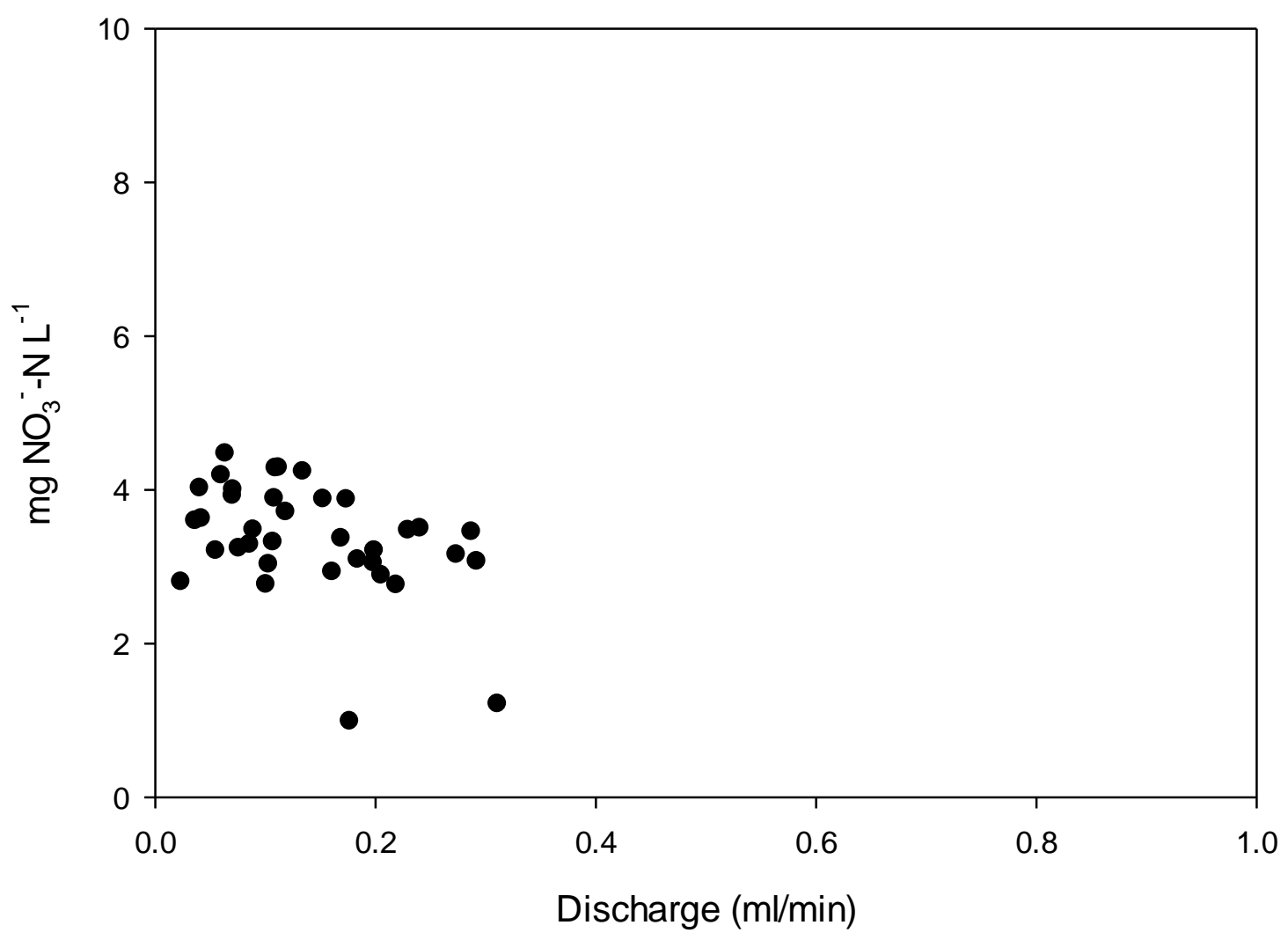

Appendix F.3 - SMC - September 
Appendix F, Page 126

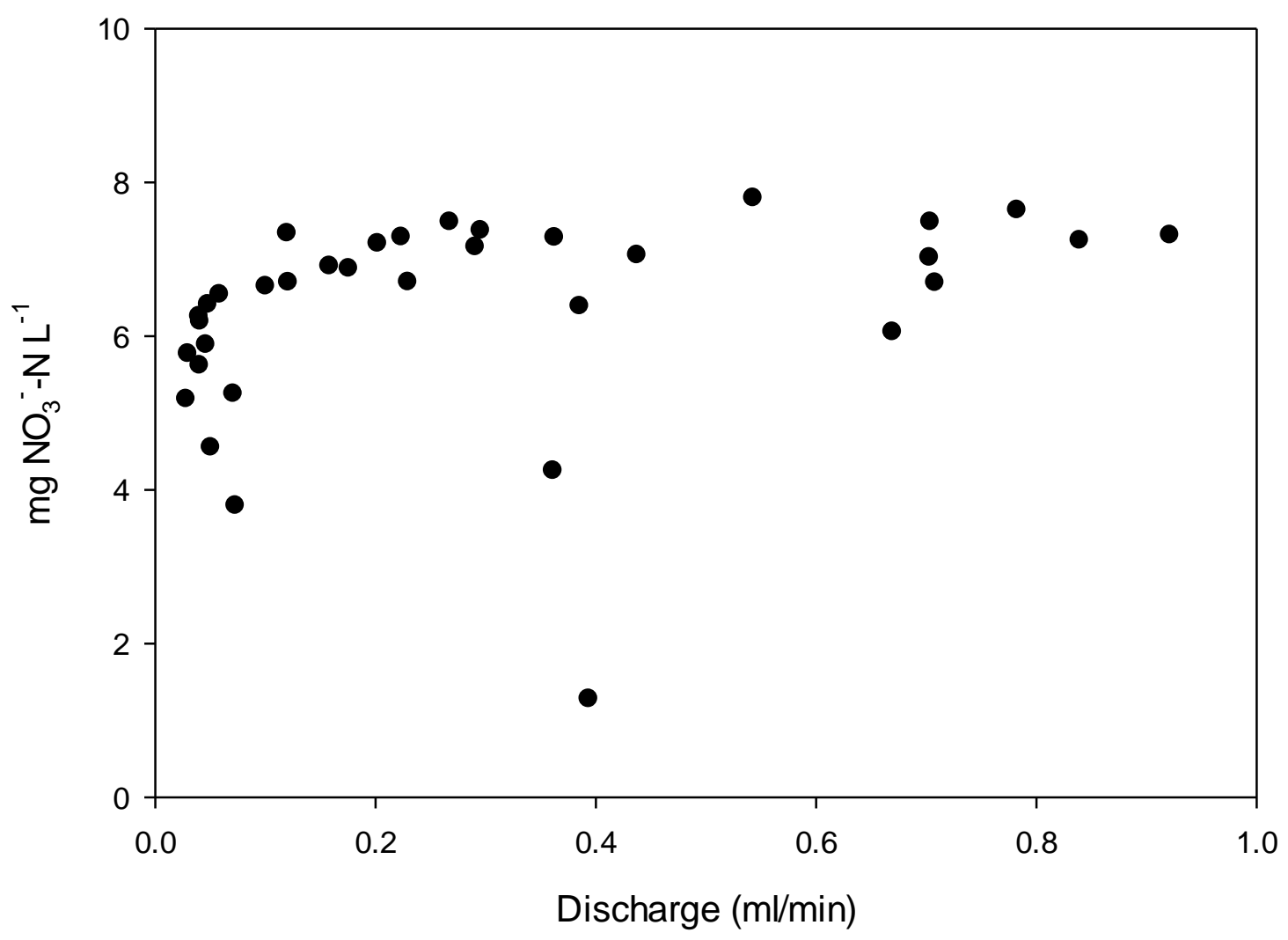

Appendix F.4 - SMD - September 


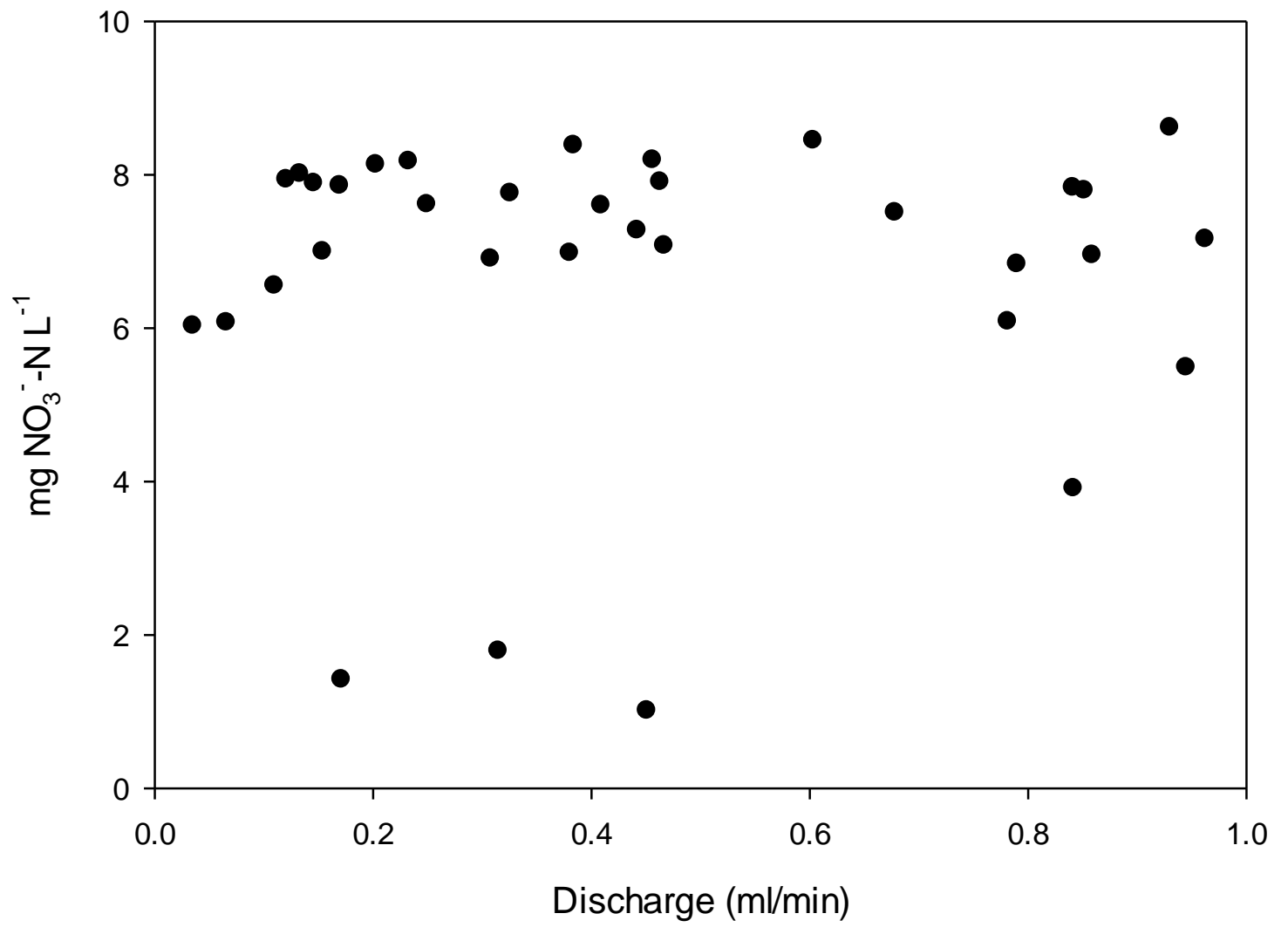

Appendix F.5 - SME - September 


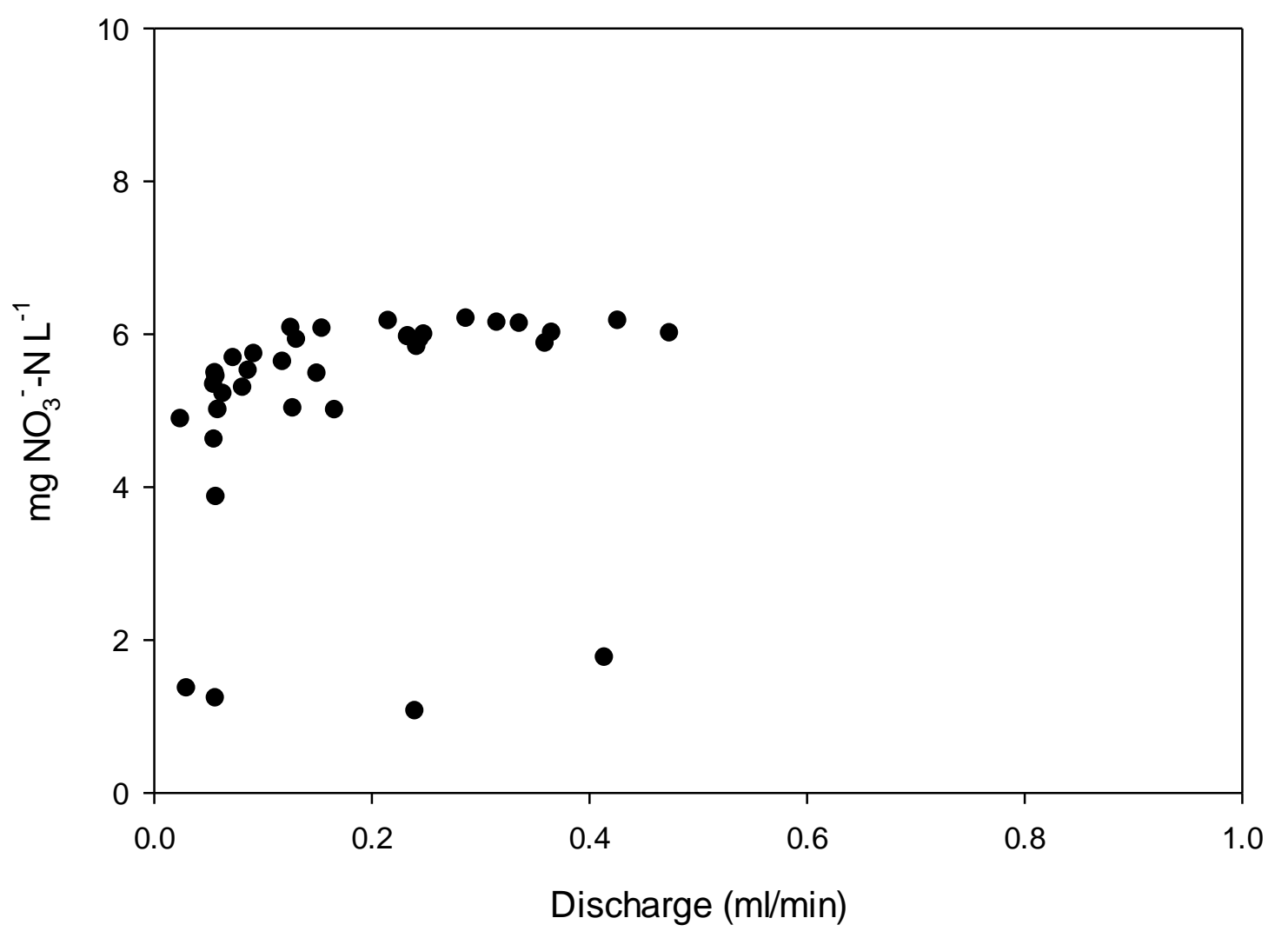

Appendix F.6 - SMF - September 


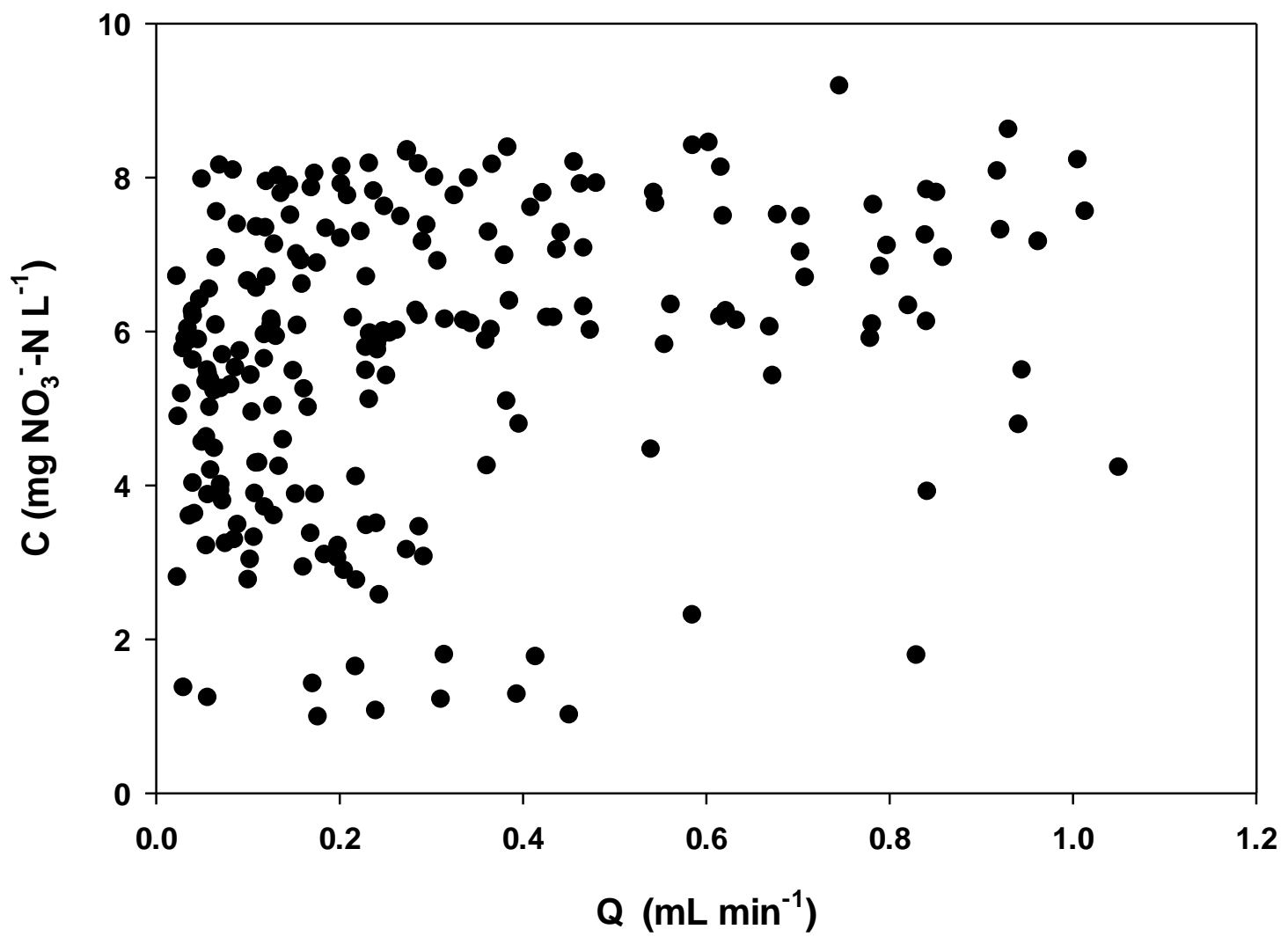

Appendix F7. Composite C vs Q plot for all the seepage meters in September 2010 
Appendix G, Page 130

7 Appendix G. Data Tables 
Appendix G, Page 131

Appendix G1. Concentration of $\mathrm{NO}_{3}{ }^{-} \mathrm{N}$ in hourly stream water samples collected in June 2010 at the Cobb Mill Creek Hillslope

Nitrate concentration $\left(\mathrm{mg} \mathrm{NO}_{3}^{-}-\mathrm{N} / \mathrm{L}\right)$

\begin{tabular}{|c|c|c|c|c|c|c|c|c|c|c|}
\hline Sample Time & 16-Jun & 17-Jun & 18-Jun & 19-Jun & 20-Jun & 21-Jun & 22-Jun & 23-Jun & 24-Jun & 25-Jun \\
\hline $6 / 15 / 10 \quad 18: 00$ & 0.09 & & & & & & & & & \\
\hline 0:00 & 2.13 & na & 2.90 & & 1.05 & 3.22 & 3.41 & 1.88 & 3.47 & 3.56 \\
\hline $1: 00$ & 2.37 & 1.75 & 2.86 & & 3.27 & 3.23 & 3.45 & 3.19 & 2.20 & 3.60 \\
\hline $2: 00$ & 2.79 & 2.70 & 2.68 & & 3.28 & 3.33 & 3.47 & 3.18 & 3.42 & 3.42 \\
\hline 3:00 & 1.47 & 3.18 & 2.62 & & 3.19 & 3.26 & 3.45 & 2.76 & 0.77 & 3.62 \\
\hline 4:00 & 2.40 & 2.34 & 2.49 & & 2.60 & 1.16 & 3.45 & 3.09 & 3.11 & 3.59 \\
\hline $5: 00$ & 0.76 & 1.37 & 2.89 & & 3.00 & 1.39 & 1.58 & 3.08 & 3.20 & 3.56 \\
\hline $6: 00$ & 1.75 & 2.63 & 2.80 & & 3.05 & 3.01 & 2.93 & 3.06 & 3.14 & 3.54 \\
\hline 7:00 & 2.46 & 2.63 & 0.59 & & 3.05 & 3.02 & 3.17 & 3.02 & 1.35 & 3.32 \\
\hline $8: 00^{*}$ & 2.49 & 2.65 & 2.89 & & 3.01 & 1.45 & 2.20 & 3.00 & 3.12 & 3.29 \\
\hline 9:00 & 2.49 & 1.96 & 2.92 & & 2.87 & 3.03 & 3.15 & 3.02 & 0.25 & 3.30 \\
\hline $10: 00^{*}$ & 2.49 & 2.64 & 2.92 & & 2.99 & 3.01 & 2.95 & 2.87 & 3.11 & 3.18 \\
\hline $11: 00$ & 2.53 & 1.19 & 1.98 & & 2.98 & 1.60 & 3.05 & 2.95 & 2.87 & 3.00 \\
\hline $12: 00$ & 2.48 & 1.82 & 2.86 & & 2.14 & 2.53 & 2.97 & 2.87 & 2.98 & \\
\hline $13: 00$ & 2.53 & 1.90 & 2.84 & & 0.89 & 2.86 & 2.25 & 2.84 & 2.34 & \\
\hline 14:00 & 2.39 & 2.54 & 2.85 & & 2.41 & 2.74 & 2.90 & 2.80 & 2.90 & \\
\hline $15: 00$ & 2.12 & 2.48 & 2.90 & & 0.79 & 2.83 & 2.89 & 2.79 & 2.95 & \\
\hline $16: 00$ & 1.15 & 2.51 & 2.92 & & 2.91 & 2.75 & 2.92 & 1.39 & 2.94 & \\
\hline $17: 00$ & 1.78 & 0.45 & 1.60 & & 1.82 & 2.68 & 2.93 & 2.90 & 2.94 & \\
\hline $18: 00$ & 2.22 & 2.63 & 2.61 & & 0.99 & 2.91 & 1.00 & 2.94 & 2.99 & \\
\hline $19: 00$ & 1.07 & 2.65 & 3.12 & & 2.99 & 2.64 & 1.53 & 2.96 & 3.07 & \\
\hline $20: 00$ & 0.62 & 2.71 & 3.11 & & 3.07 & 1.58 & 3.02 & 2.40 & 3.16 & \\
\hline $21: 00$ & 2.59 & 2.75 & 3.16 & & 3.10 & 1.65 & 3.09 & 3.22 & 3.21 & \\
\hline 22:00 & 2.64 & 2.75 & 3.25 & & 2.89 & 2.24 & 1.56 & 3.32 & 3.29 & \\
\hline 23:00 & 0.81 & 2.86 & 2.45 & & 1.06 & 0.67 & 2.97 & 3.41 & 3.46 & \\
\hline
\end{tabular}


Appendix G, Page 132

Appendix G2. Rates of inseepage in the seepage meters deployed in June 2010

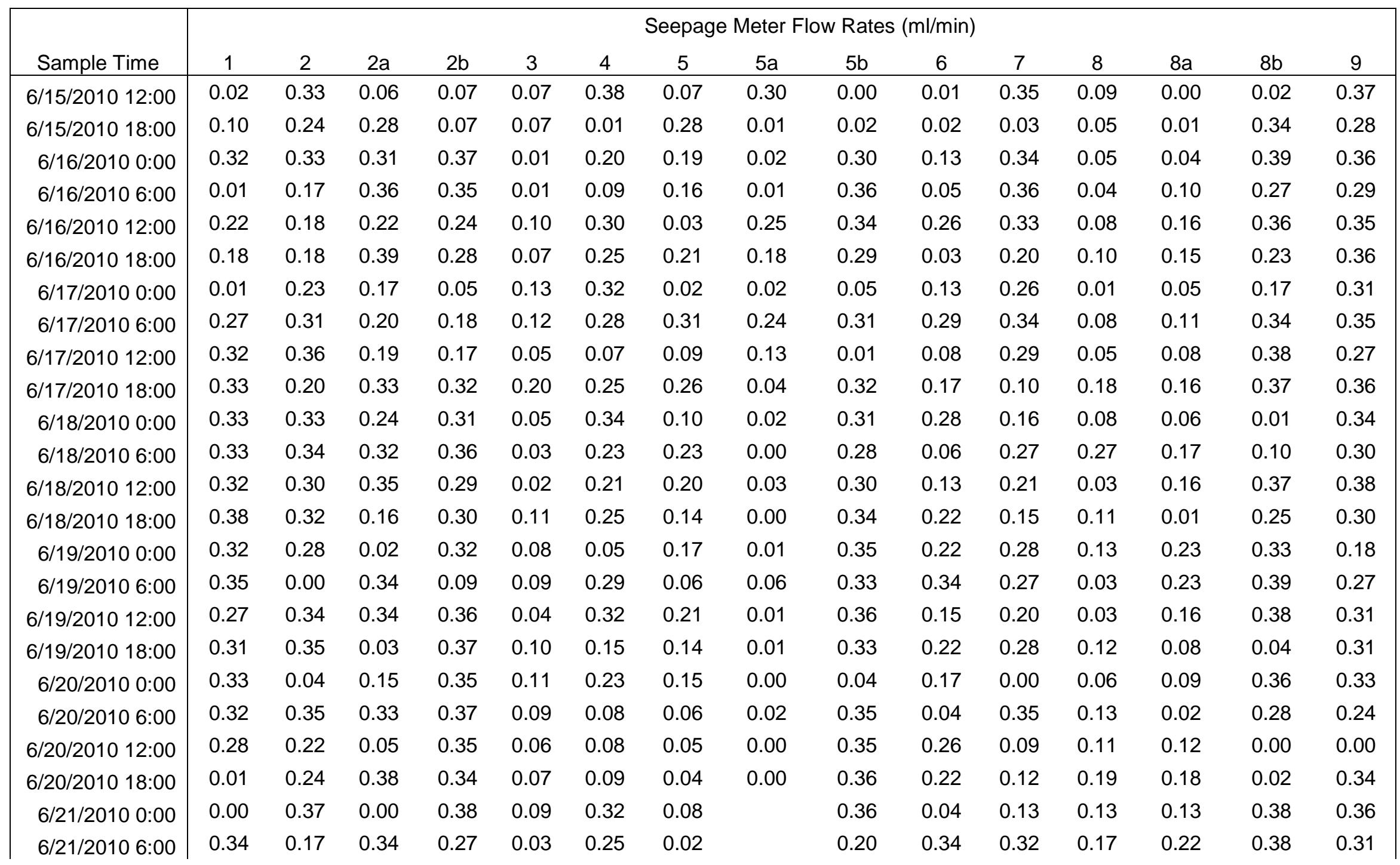


Appendix G, Page 133

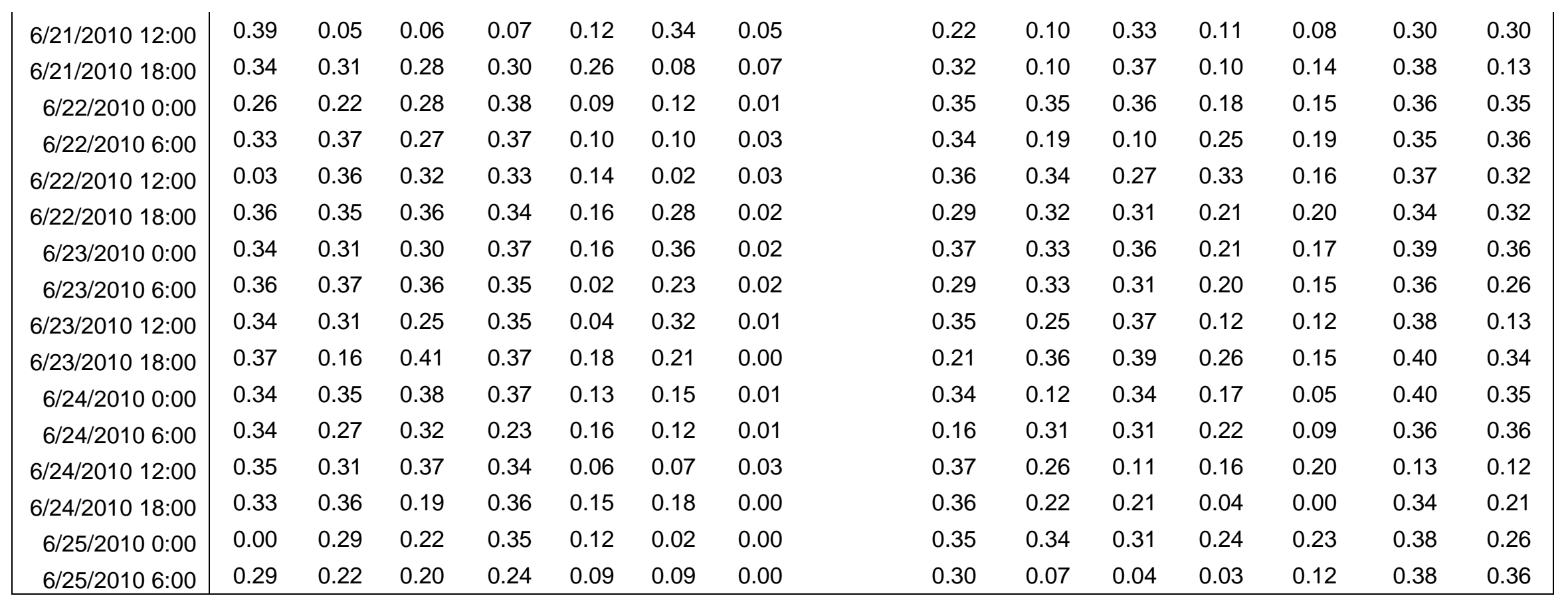


Appendix G, Page 134

Appendix G3. Concentration of nitrate in seepage meters deployed in June 2010

\begin{tabular}{|c|c|c|c|c|c|c|c|c|c|c|c|c|c|c|c|}
\hline \multirow{2}{*}{ Sample Time } & \multicolumn{15}{|c|}{ Seepage Meter Nitrate concentrations $\left(\mathrm{mg} \mathrm{ml}^{-1}\right)$} \\
\hline & 1 & 2 & $2 a$ & $2 b$ & 3 & 4 & 5 & $5 a$ & $5 b$ & 6 & 7 & 8 & $8 a$ & $8 b$ & 9 \\
\hline $6 / 15 / 201012: 00$ & 6.65 & 3.01 & 0.78 & 5.03 & 0.06 & 0.08 & 0.23 & 0.26 & & 0.60 & 0.20 & 0.44 & & 1.12 & 0.07 \\
\hline 6/15/2010 18:00 & 6.73 & 1.16 & 0.22 & 4.30 & 0.27 & 1.69 & 0.25 & 0.56 & 1.54 & 0.69 & 0.26 & 0.31 & 0.47 & 0.08 & 0.05 \\
\hline 6/16/2010 0:00 & 7.55 & 2.95 & 0.39 & 2.48 & 0.48 & 0.04 & 0.90 & & 1.41 & 2.89 & & & & & \\
\hline 6/16/2010 6:00 & 0.25 & 2.75 & 0.46 & 5.23 & 1.93 & 0.17 & 0.14 & 2.04 & 4.34 & 0.54 & 0.06 & 1.42 & 0.52 & 0.02 & \\
\hline 6/16/2010 12:00 & 3.89 & 1.43 & 0.53 & 2.59 & 1.05 & & 0.21 & 0.10 & 4.23 & 0.01 & & 0.07 & 0.06 & 0.06 & \\
\hline 6/16/2010 18:00 & 5.10 & 2.50 & 0.48 & 5.74 & 0.65 & 0.01 & 0.02 & 0.07 & 1.67 & & 0.18 & 0.07 & 0.08 & 0.21 & 0.05 \\
\hline 6/17/2010 0:00 & 5.74 & 2.85 & 0.65 & 4.95 & 1.74 & 0.17 & 0.22 & 0.27 & 4.35 & 0.02 & 0.08 & 1.05 & 2.20 & 0.32 & \\
\hline 6/17/2010 6:00 & 7.51 & 2.97 & 0.92 & 4.60 & 1.16 & 0.13 & 0.06 & 1.65 & 2.60 & 0.08 & 0.10 & 1.39 & 1.18 & 0.06 & \\
\hline 6/17/2010 12:00 & 8.45 & 2.74 & 0.82 & 2.39 & 1.07 & 0.20 & 0.06 & 2.14 & 2.37 & 0.65 & 0.08 & 1.80 & 0.61 & 0.04 & \\
\hline 6/17/2010 18:00 & 1.67 & 4.01 & 0.99 & 5.12 & 1.75 & 0.04 & 0.05 & 0.65 & 1.83 & 0.66 & 0.32 & 1.81 & 0.09 & 0.29 & 0.07 \\
\hline 6/18/2010 0:00 & 7.66 & 2.99 & 0.94 & 2.72 & 1.95 & & 0.04 & 2.23 & 5.16 & 0.16 & 0.29 & 0.26 & 2.28 & 2.09 & 0.07 \\
\hline 6/18/2010 6:00 & 1.88 & 0.50 & 0.95 & 3.11 & 2.70 & 0.25 & 1.21 & & 5.11 & 2.62 & 0.02 & 2.34 & 0.66 & 1.72 & \\
\hline 6/18/2010 12:00 & 7.95 & 2.99 & 1.04 & 5.70 & 2.29 & 0.13 & 0.27 & 1.28 & 5.01 & 0.92 & 0.22 & 0.12 & 0.06 & 0.11 & 0.09 \\
\hline 6/18/2010 18:00 & 7.69 & 3.03 & 1.69 & 5.56 & 0.91 & 0.07 & 0.14 & 1.19 & 4.88 & 1.43 & 0.06 & 0.03 & 2.12 & 0.10 & 0.02 \\
\hline 6/19/2010 0:00 & 5.54 & 3.00 & 2.26 & 0.71 & 0.86 & 0.13 & 0.09 & 1.07 & 1.38 & 0.93 & 0.97 & 0.05 & 0.42 & 0.03 & 0.06 \\
\hline 6/19/2010 6:00 & 8.10 & & 0.56 & 3.89 & 1.96 & & 0.66 & 2.91 & 2.15 & 1.20 & 0.04 & 2.99 & 0.55 & 0.02 & 0.04 \\
\hline 6/19/2010 12:00 & 8.44 & 3.15 & 0.13 & 6.07 & 0.80 & 0.05 & 0.03 & 2.22 & 5.39 & 0.12 & 0.47 & 2.96 & 0.24 & 0.03 & 0.21 \\
\hline 6/19/2010 18:00 & 8.51 & 3.06 & 2.18 & 3.81 & 1.06 & 0.14 & 0.08 & 2.21 & 5.41 & 1.09 & 0.65 & 0.11 & 0.54 & 0.49 & 0.24 \\
\hline 6/20/2010 0:00 & 8.67 & 3.08 & 1.51 & 4.89 & 1.41 & & 0.08 & 0.56 & 3.00 & 0.02 & & 0.18 & 0.71 & 0.05 & 0.02 \\
\hline 6/20/2010 6:00 & 8.42 & 1.17 & 0.38 & 2.95 & 1.40 & 3.16 & 0.35 & 1.38 & 5.42 & 1.53 & 0.19 & 0.09 & 2.29 & 0.02 & \\
\hline 6/20/2010 12:00 & 8.23 & 3.26 & 1.44 & 6.24 & 1.68 & 0.80 & 0.81 & 2.00 & 5.54 & 0.06 & 0.72 & 0.31 & 0.13 & & \\
\hline 6/20/2010 18:00 & 2.08 & 3.18 & 0.93 & 5.88 & 0.27 & 0.26 & 1.07 & & 5.24 & 0.02 & 0.19 & 0.38 & 1.24 & 2.68 & 1.29 \\
\hline 6/21/2010 0:00 & 3.05 & 3.02 & 2.17 & 0.07 & 0.53 & & & & 5.56 & 0.04 & 0.36 & 1.42 & 0.76 & 0.03 & 0.13 \\
\hline 6/21/2010 6:00 & 7.58 & 2.16 & 0.73 & 6.01 & 3.12 & 0.24 & 0.06 & & 1.78 & 0.05 & 0.16 & 0.11 & 2.19 & 0.06 & 0.15 \\
\hline
\end{tabular}




\begin{tabular}{|c|c|c|c|c|c|c|c|c|c|c|c|c|c|c|}
\hline 6/21/2010 12:00 & 7.52 & 3.00 & 0.91 & 2.62 & 1.69 & 0.04 & 1.07 & 5.40 & 1.07 & 0.06 & 0.25 & 0.47 & 0.14 & 0.13 \\
\hline 6/21/2010 18:00 & 6.14 & 2.80 & 0.79 & 5.97 & 2.43 & 0.78 & 0.23 & 2.56 & 0.50 & 0.03 & 0.50 & 0.05 & 0.02 & 0.31 \\
\hline 6/22/2010 0:00 & 7.97 & 2.77 & 1.41 & 6.01 & 1.34 & 0.28 & 2.43 & 5.32 & 0.07 & 0.18 & 0.03 & 0.66 & 0.24 & \\
\hline 6/22/2010 6:00 & 8.12 & 2.83 & 1.73 & 5.87 & 0.97 & 0.23 & 2.81 & 5.27 & 0.83 & 0.89 & 1.14 & 1.42 & 0.02 & 0.02 \\
\hline 6/22/2010 12:00 & 8.17 & 0.32 & 1.76 & 5.52 & 2.25 & 2.99 & 2.11 & 5.59 & 0.61 & 0.30 & 0.44 & 0.64 & & 0.03 \\
\hline 6/22/2010 18:00 & 2.81 & 2.92 & 1.71 & 3.26 & 2.67 & 0.17 & 2.85 & 1.99 & 0.26 & 0.17 & 1.20 & 1.01 & 0.04 & 0.08 \\
\hline 6/23/2010 0:00 & 8.68 & 1.65 & 2.16 & 6.05 & 0.61 & 0.09 & 2.66 & 5.28 & 0.13 & 0.24 & 1.40 & 0.18 & & 0.12 \\
\hline 6/23/2010 6:00 & 8.64 & 2.93 & 1.71 & 5.62 & 1.18 & 0.42 & 2.66 & 5.27 & 0.03 & 0.27 & 0.87 & 0.47 & 0.01 & 0.16 \\
\hline 6/23/2010 12:00 & 8.78 & 1.26 & 2.51 & 5.80 & 2.10 & 0.50 & 2.53 & 1.22 & 1.14 & 0.02 & 0.14 & 1.71 & 0.14 & 0.31 \\
\hline 6/23/2010 18:00 & 8.77 & 3.06 & 2.35 & 5.27 & 2.15 & 0.78 & & 5.05 & 1.24 & 0.04 & 0.55 & 0.71 & & 0.02 \\
\hline 6/24/2010 0:00 & 8.68 & 1.43 & 2.05 & 5.18 & 1.85 & 0.24 & 0.78 & 5.64 & 0.63 & 0.16 & 1.26 & 1.65 & 0.06 & 0.11 \\
\hline 6/24/2010 6:00 & 8.56 & 2.86 & 2.02 & 5.58 & 1.52 & 0.16 & & 1.47 & 1.15 & 0.17 & 1.92 & 1.25 & & 0.21 \\
\hline 6/24/2010 12:00 & 8.70 & 2.89 & 2.42 & 6.06 & 0.38 & 0.60 & 0.75 & 0.53 & 0.40 & 2.76 & 1.95 & 2.01 & 1.31 & 1.12 \\
\hline 6/24/2010 18:00 & 8.62 & 2.85 & 2.38 & 5.81 & 2.63 & 1.07 & & 5.50 & 0.19 & 0.20 & 1.28 & 5.49 & 0.08 & 0.21 \\
\hline 6/25/2010 0:00 & & 2.81 & 1.66 & 5.44 & 1.86 & 1.17 & & 5.25 & 0.60 & 0.01 & 0.90 & 0.73 & 0.03 & 0.07 \\
\hline 6/25/2010 6:00 & 5.74 & 2.03 & 1.90 & 5.81 & 2.86 & 0.13 & & 5.93 & 0.11 & 1.12 & 1.55 & 1.41 & 0.01 & 0.02 \\
\hline
\end{tabular}


Appendix G, Page 136

Appendix G4. Concentration of nitrate in hourly stream water samples collected in September 2010 at the Cobb Mill Creek Hillslope

\begin{tabular}{|c|c|c|c|c|c|c|c|c|c|}
\hline \multirow[b]{2}{*}{ Sample Time } & \multicolumn{4}{|c|}{$\mathrm{mg} \mathrm{NO}_{3}{ }^{-}-\mathrm{N} / \mathrm{L}$} & \multirow[b]{2}{*}{ Sample Time } & \multirow[b]{2}{*}{ 23-Sept } & \multirow[b]{2}{*}{ 24-Sept } & \multirow[b]{2}{*}{ 25-Sept } & \multirow[b]{2}{*}{ 26-Sept } \\
\hline & 23-Sept & 24-Sept & 25-Sept & 26-Sept & & & & & \\
\hline 0:00 & & 6.04 & & 5.84 & $13: 00$ & 6.25 & 5.89 & 5.93 & \\
\hline $1: 00$ & & 6.08 & 5.84 & 1.53 & $14: 00$ & 6.28 & 6.01 & 5.95 & \\
\hline $2: 00$ & & 5.68 & & 3.34 & $15: 00$ & 6.27 & 3.97 & 5.92 & \\
\hline 3:00 & & 6.07 & & 5.74 & $16: 00$ & 6.23 & 6.00 & 5.98 & \\
\hline $4: 00$ & & 5.85 & & 5.78 & $17: 00$ & 6.25 & 6.01 & 5.91 & \\
\hline 5:00 & & 5.97 & 5.70 & 5.75 & $18: 00$ & & 6.28 & 5.41 & \\
\hline $6: 00$ & & 6.08 & & 5.77 & 19:00 & 6.10 & 5.95 & 5.91 & \\
\hline 7:00 & & 4.97 & & 5.65 & 20:00 & 5.96 & 5.93 & 5.87 & \\
\hline $8: 00$ & & 3.77 & & 5.73 & $21: 00$ & 6.12 & 5.83 & 4.53 & \\
\hline 9:00 & & 6.01 & & 5.75 & $22: 00$ & 5.81 & & 5.75 & \\
\hline $10: 00$ & & 5.08 & & 5.75 & 23:00 & 6.09 & & 5.61 & \\
\hline $11: 00$ & & 6.04 & 5.82 & 5.78 & & & & & \\
\hline $12: 00$ & 6.13 & 5.88 & 5.83 & & & & & & \\
\hline
\end{tabular}


Appendix G5. Discharge into seepage meters deployed in September 2010

Appendix G, Page 137

\begin{tabular}{|c|c|c|c|c|c|c|}
\hline \multirow[b]{2}{*}{ Sample Time } & \multicolumn{6}{|c|}{ Seepage Meter Flow Rates (mL / min) } \\
\hline & SM A & SM B & SM C & SM D & SM E & SM F \\
\hline $9 / 23 / 1014: 00$ & 0.94 & 0.80 & 0.12 & 0.18 & 0.20 & 0.17 \\
\hline 9/23/10 16:00 & 0.23 & 0.26 & 0.18 & 0.04 & 0.23 & 0.13 \\
\hline 9/23/10 18:00 & 0.23 & 0.15 & 0.02 & 0.12 & 0.31 & 0.06 \\
\hline 9/23/10 20:00 & 0.25 & 0.54 & 0.11 & 0.06 & 0.15 & 0.08 \\
\hline 9/23/10 22:00 & 0.22 & 0.07 & 0.06 & 0.78 & 0.46 & 0.09 \\
\hline $9 / 24 / 100: 00$ & 0.43 & 0.02 & 0.06 & 0.05 & 0.93 & 0.03 \\
\hline 9/24/10 2:00 & 0.03 & 0.27 & 0.15 & 0.07 & 0.38 & 0.06 \\
\hline 9/24/10 4:00 & 0.26 & 0.13 & 0.07 & 0.12 & 0.60 & 0.07 \\
\hline 9/24/10 6:00 & 0.13 & 0.04 & 0.11 & 1.01 & 0.12 & 0.09 \\
\hline 9/24/10 8:00 & 0.62 & 0.07 & 0.09 & 0.54 & 0.25 & 0.25 \\
\hline 9/24/10 10:00 & 0.14 & 0.09 & 0.09 & 0.03 & 0.46 & 0.15 \\
\hline 9/24/10 12:00 & 0.55 & 0.37 & 0.17 & 0.39 & 0.78 & 0.29 \\
\hline $9 / 24 / 1014: 00$ & 0.24 & 0.22 & 0.24 & 0.71 & 0.38 & 0.43 \\
\hline 9/24/10 16:00 & 0.10 & 0.08 & 0.11 & 0.04 & 0.17 & 0.13 \\
\hline 9/24/10 18:00 & 0.40 & 0.07 & 0.07 & 0.07 & 0.07 & 0.05 \\
\hline 9/24/10 20:00 & 0.06 & 0.17 & 0.04 & 0.10 & 0.33 & 0.02 \\
\hline 9/24/10 22:00 & 0.10 & 0.21 & 0.13 & 0.03 & 0.31 & 0.06 \\
\hline 9/25/10 0:00 & 0.13 & 0.19 & 0.04 & 0.30 & 0.47 & 0.15 \\
\hline $9 / 25 / 102: 00$ & 0.12 & 0.48 & 0.17 & 0.05 & 0.79 & 0.06 \\
\hline 9/25/10 4:00 & 0.54 & 0.11 & 0.06 & 0.05 & 0.86 & 0.06 \\
\hline 9/25/10 6:00 & 0.82 & 0.27 & 0.20 & 0.36 & 0.15 & 0.23 \\
\hline $9 / 25 / 108: 00$ & 0.62 & 0.29 & 0.16 & 0.04 & 0.45 & 0.06 \\
\hline 9/25/10 10:00 & 0.34 & 0.24 & 0.04 & 0.27 & 0.85 & 0.06 \\
\hline 9/25/10 12:00 & 0.24 & 0.13 & 0.10 & 0.39 & 0.96 & 0.12 \\
\hline $9 / 25 / 1014: 00$ & 0.16 & 0.30 & 0.08 & 0.22 & 0.68 & 0.13 \\
\hline 9/25/10 16:00 & 0.63 & 0.62 & 0.22 & 0.44 & 0.41 & 0.36 \\
\hline 9/25/10 18:00 & 0.23 & 0.75 & 0.31 & 0.70 & 1.05 & 0.24 \\
\hline 9/25/10 20:00 & 0.38 & 0.14 & 0.23 & 0.29 & 0.84 & 0.47 \\
\hline $9 / 25 / 1022: 00$ & 0.56 & 0.05 & 0.21 & 0.20 & 1.01 & 0.23 \\
\hline 9/26/10 0:00 & 0.47 & 0.42 & 0.18 & 0.67 & 0.95 & 0.41 \\
\hline 9/26/10 2:00 & 0.59 & 0.20 & 0.10 & 0.84 & 0.84 & 0.22 \\
\hline
\end{tabular}


Appendix G, Page 138

\begin{tabular}{|l|l|l|l|l|l|}
\hline 9/26/10 4:00 & 0.84 & 0.59 & 0.20 & 0.70 & 0.13 \\
\hline $9 / 26 / 106: 00$ & 0.16 & 0.92 & 0.29 & 0.92 & 0.04 \\
\hline $9 / 26 / 108: 00$ & 0.67 & 0.78 & 0.11 & 0.36 & 0.34 \\
\hline $9 / 26 / 1010: 00$ & 0.83 & 0.34 & 0.27 & 0.23 & 0.11 \\
\hline $9 / 26 / 1012: 00$ & 0.28 & 0.62 & 0.29 & 0.16 & 0.24 \\
\hline
\end{tabular}


Appendix G6. Concentration of nitrate in seepage meters deployed in September 2010

Appendix G, Page 139

\begin{tabular}{|c|c|c|c|c|c|c|}
\hline \multirow[b]{2}{*}{ Sample Time } & \multicolumn{6}{|c|}{ Seepage Meter Nitrate Concentrations $\left(\mathrm{mg} \mathrm{L}^{-1}\right)$} \\
\hline & SM A & SM B & SM C & SM D & SM E & SM F \\
\hline $9 / 23 / 1014: 00$ & 4.79 & 7.11 & 3.71 & 3.71 & 8.14 & 5.01 \\
\hline 9/23/10 16:00 & 5.11 & 5.98 & 3.09 & 3.09 & 8.18 & 5.03 \\
\hline 9/23/10 18:00 & 5.49 & 7.50 & 2.80 & 2.80 & & 4.63 \\
\hline 9/23/10 20:00 & 5.42 & 7.66 & 4.29 & 4.29 & 7.89 & 5.30 \\
\hline 9/23/10 22:00 & 4.10 & 7.55 & 4.48 & 4.48 & 7.91 & 5.74 \\
\hline 9/24/10 0:00 & 6.18 & 6.71 & 3.21 & 3.21 & 8.62 & \\
\hline 9/24/10 2:00 & 5.90 & 8.33 & 3.88 & 3.88 & 8.39 & 5.22 \\
\hline 9/24/10 4:00 & 6.01 & 7.13 & 3.93 & 3.93 & 8.45 & 5.69 \\
\hline $9 / 24 / 106: 00$ & 6.15 & 5.88 & 4.28 & 4.28 & 7.94 & 5.52 \\
\hline 9/24/10 8:00 & 6.26 & 8.16 & 3.48 & 3.48 & 7.62 & 6.00 \\
\hline 9/24/10 10:00 & 4.59 & 7.39 & 3.29 & 3.29 & 8.20 & 6.07 \\
\hline 9/24/10 12:00 & 5.83 & 8.17 & 3.37 & 3.37 & 6.09 & 6.20 \\
\hline $9 / 24 / 1014: 00$ & 5.76 & & 3.50 & 3.50 & 6.98 & 6.18 \\
\hline 9/24/10 16:00 & 4.95 & 8.09 & 3.32 & 3.32 & 7.86 & 6.08 \\
\hline 9/24/10 18:00 & 4.79 & 6.95 & 4.00 & 4.00 & 6.08 & 5.34 \\
\hline 9/24/10 20:00 & 5.36 & 8.05 & 4.02 & 4.02 & 7.76 & 4.89 \\
\hline 9/24/10 22:00 & 5.43 & 7.76 & 4.24 & 4.24 & 6.91 & 3.87 \\
\hline 9/25/10 0:00 & 6.10 & 7.33 & 3.60 & 3.60 & 7.08 & 5.48 \\
\hline 9/25/10 2:00 & 5.95 & 7.92 & 3.88 & 3.88 & 6.84 & 5.49 \\
\hline 9/25/10 4:00 & 4.46 & 7.35 & 4.19 & 4.19 & 6.96 & \\
\hline 9/25/10 6:00 & 6.33 & 8.35 & 3.21 & 3.21 & 7.00 & 5.97 \\
\hline 9/25/10 8:00 & 6.19 & 8.17 & 2.93 & 2.93 & & 5.01 \\
\hline 9/25/10 10:00 & 6.10 & 7.82 & 3.62 & 3.62 & 7.80 & 5.45 \\
\hline
\end{tabular}




\begin{tabular}{|r|rllllc|} 
9/25/10 12:00 & & & & \multicolumn{3}{c}{ Appendix G, Page 140} \\
9/25/10 14:00 & & & 3.03 & 3.03 & 7.17 & 5.64 \\
9/25/10 16:00 & 5.25 & 8.00 & 3.24 & 3.24 & 7.51 & 5.93 \\
9/25/10 18:00 & 6.14 & 8.13 & 2.76 & 2.76 & 7.60 & 5.88 \\
9/25/10 20:00 & 5.79 & 9.18 & & & 4.23 & \\
9/25/10 22:00 & 5.09 & 7.79 & 3.47 & 3.47 & 7.84 & 6.01 \\
9/26/10 0:00 & 6.34 & 7.97 & 2.89 & 2.89 & 8.22 & 5.96 \\
$9 / 26 / 102: 00$ & 6.32 & 7.79 & & & 5.49 & \\
$9 / 26 / 104: 00$ & & 7.91 & 2.77 & 2.77 & & 6.17 \\
$9 / 26 / 106: 00$ & 6.13 & 8.41 & 3.05 & 3.05 & 8.02 & 6.15 \\
$9 / 26 / 108: 00$ & 6.61 & 8.08 & 3.07 & 3.07 & 6.04 & 6.14 \\
$9 / 26 / 1010: 00$ & 5.42 & 5.91 & 3.89 & 3.89 & 6.56 & 6.02 \\
$9 / 26 / 1012: 00$ & & 7.98 & 3.16 & 3.16 & & 5.93 \\
\hline
\end{tabular}


Appendix G, Page 141 Appendix G7. Nitrate concentrations in samples of sediment pore water extracted from several depths in September, 2010.

\begin{tabular}{cccc}
\hline & \multicolumn{2}{c}{$\mathrm{Mg} \mathrm{NO}_{3}{ }^{-}-\mathrm{N} \mathrm{L}^{-1}$ in sediment pore water } \\
\cline { 2 - 3 } Depth below sediment surface $(\mathrm{cm})$ & Profile 1 & Profile 2 \\
\hline 1 & 5.7 & 0.18 \\
2 & 3.6 & 0.5 & 0.5 \\
5 & 6.1 & 0.25 \\
\hline
\end{tabular}

